\title{
ACOMPANHAMENTO LONGITUDINAL DO SUCESSO DAS PRÓTESES SUPORTADAS POR IMPLANTES OSSEOINTEGRADOS DO SISTEMA NAPIO
}

\section{SYLVIA MARIA BASTOS CORREIA}

Tese apresentada à Faculdade de Odontologia de Bauru, da Universidade de São Paulo, como parte dos requisitos para obtenção do título de Doutor em Odontologia, área de Periodontia.

\section{BAURU}

1999 


\title{
ACOMPANHAMENTO LONGITUDINAL DO SUCESSO DAS PRÓTESES SUPORTADAS POR IMPLANTES OSSEOINTEGRADOS DO SISTEMA NAPIO
}

SYLVIA MARIA BASTOS CORREIA

\begin{abstract}
Tese apresentada à Faculdade de Odontologia de Bauru, da Universidade de São Paulo, como parte dos requisitos para obtenção do título de Doutor em Odontologia, área de Periodontia.

(Edição revista) Orientador: Aguinaldo Campos Júnior
\end{abstract}

\section{BAURU}

1999 


\section{SYLVIA MARIA BASTOS CORREIA}

29 de abril de 1969

Salvador-Bahia

José de Souza Correia

Maria Ligia Bastos Correia

1987-1991

$1992-1993$

1994-1996

1996-1999
Nascimento

Filiação

Curso de Odontologia na Faculdade de Odontologia da Universidade Federal da Bahia.

Curso de Especialização em Periodontia, na Faculdade de Odontologia de Bauru, Universidade de São Paulo.

Curso de Pós-graduação em Periodontia, ao nível de Mestrado, na Faculdade de Odontologia de Bauru, da Universidade de São Paulo.

Curso de Pós-graduação em Periodontia, ao nível de Doutorado, na Faculdade de Odontologia de Bauru, da Universidade de São Paulo. 
“Os sonhos são extremamente importantes. Não os conseguimos se não os imaginamos."

"A lição mais importante que se pode aprender quando se vence e que se pode" Dave Weinbaum em Forbes

A Deus, que sempre iluminou e guiou os meus caminhos me dando forças para vencer as provações.

\section{A Maria Ligia e José, meus amados e abençoados pais,}

Agradeço de coração pelo amor, dedicação, apoio e confiança constantes durante toda a minha vida. Os responsáveis pela minha formação moral e intelectual, conduz̨indo-me à compreensão dos preceitos de idoneidade, solidariedade, boa conduta e acima de tudo respeito pelo ser bumano. Como reconhecimento por toda uma jornada com este intuito, sendo vocês diretamente responsáveis por esta conquista.

Minha eterna gratidão.....

\section{À minba avó "in memorium",}

Meu muito obrigada pelo seu constante zelo e orações pelo meu bem-estar com profundo desvelo, amor e carinho e que mesmo a distância deve estar assistindo o término desta jornada.

Minha lembrança sempre....

\section{A Júnior e Marco, meus queridos irmãos e verdadeiros amigos,}

Obrigada pelo apoio, motivação, amizade e carinho extremo devotados durante toda a minha vida e especialmente quando eu estava a distância..

\section{A Thaís, minha cunbada irmã,}

Agradecimento sincero pela sua amizade, carinho e apoio me incentivando durante toda esta jornada.

\section{Aos meus amados sobrinbos Fábio e Vitor,}

Agradeço pelo amor, carinho e especialmente os momentos inesqueciveis de "folia e bagunça"....

\section{A Reynaldo,}

Exemplo de pesquisador brilhante com indagações e pensamento analítico privilegiado, agradeço pela contribuição na minha formação cientifica, como também pelo incentivo e empenho para o término desta jornada. Aos meus tios Ana Maria e Carlito pelo apoio, dedicaşão e principalmente por acreditarem em mim Às minhas tias, Dinalva e Mirinba,

Agradeço o zelo por mim como verdadeiras mães com muito amor, dedicação e carinho e que sempre me apoiaram e acreditaram na conquista deste sonho.

À compreensão de todos os que me querem bem, pela renúncia e tempo de convivio subtraídos para a realização deste ideal. 


\section{Agradeço de modo especial}

Ao Professor Dr. Aguinaldo Campos Júnior, pela orientação deste trabalho e por todos os ensinamentos transmitidos durante o curso de Especialização, Mestrado e Doutorado.

Ao Prof. Dr. Euloir Passanezi pelos conhecimentos ensinados durante estes 7 anos com extrema dedicação, e à sua família pela amizade nestes anos de convivio, e em especial ao casal de queridos amigos Adriana e Eduardo Sant'ana, pela profunda amizade, apoio e incentivo durante toda a minha estadia em Bauru.

Aos pacientes acompanhados durante os dois anos, pois sem eles não seria possivel a execução deste trabalho.

Aos docentes da Disciplina de Periodontia, Prof. Dr. Deoclécio Nahás e Prof. Dr. Sebastião L.A. Greghi, pelos conhecimentos transmitidos com extrema dedicação e carinho.

Ao Prof. Dr. Urbino Tunes, responsável pela minha iniciação na especialidade de Periodontia, e incentivador do meu aperfeiçoamento profissional, o meu reconhecimento.

A Dr. Deporter, por me abrir as portas da Universidade de Toronto dando a oportunidade de acompanhar durante 6 meses as atividades acadêmicas e clinicas, e especialmente pelo apoio e atenção incondicionais.

Às amigas da Universidade de Toronto que me acolheram calorosamente $e$ com os quais tive o prazer de trabalhar Karen, Caroline, Susan e Nancy 
A Omar Gabriel, pesquisador brilhante, ortodontista competentíssimo e acima de tudo pessoa humana exemplar.

A minha querida Batistinha que cuidou de mim por mais de 20 anos com profundo desvelo e carinho

À tia Dêde, D. Dulce, tia Dulcinéa "in memorium" e tio Hélio, sempre afetuosos, pelo amor, apoio e amizade demonstrados desde a minha infância.

Aos meus tios de coração Noêmia e Edvaldo "in memorium", pela amizade, carinho e amor.

À Silvinha, companheira durante 4 anos a quem considero como irmã pelos momentos de extrema amizade, carinho, lealdade e confiança.

A querida amiga Celiane pela sua intensa dedicação, lealdade e apoio.

Ao amigo de coração Fabricio e a tia pela dedicação, presteza e extrema boa vontade em colaborar sempre em todos os momentos.

A Melissa e Marcia que me acolheram de forma carinhosa, alegre e hospitaleira.

Aos meus colegas de Doutorado, Emildre, Eduardo, Damé, Mário Taba Maria do Carmo e Ana Lúcia os meus sinceros agradecimentos pela amizade compartilhada nos últimos anos.

A Anahy, que me ajudou diretamente na realização do atendimento dos pacientes de forma extremamente solicita, desprendida e atenciosa. 
Aos funcionários do Departamento de Periodontia, Adriane, Ângela, Edilaine, Ivânia, Marco, Neuza, pela atenção dispensada sempre de forma cordial e carinhosa.

À Faculdade de Odontologia de Bauru, pelas condições oferecidas para a realização deste curso.

À Comissão dos Cursos de Pós-graduação da Faculdade de Odontologia de Bauru.

A FAPESP pela concessão do recurso financeiro fundamental à realização deste trabalho.

A todos os professores, que de maneira direta ou indireta participaram do curso de pós-graduação em Periodontia ao nivel de Doutorado da FOB-USP, pela dedicação demonstrada.

Aos colegas dos cursos de Pós-graduação em Cirurgia, Dentística, Diagnóstico, Endodontia, Materiais Dentários, Ortodontia, Odontopediatria, Patologia e Prótese pelo convivio durante esses anos.

Aos funcionários da pós-graduação e da Biblioteca da FOB-USP, pela atenção recebida durante esses anos.

Aos funcionários da xerox da $A P G$, sempre muito solicitos, prestativos $e$ educados.

A todos aqueles que direta e indiretamente contribuíram para a realização deste trabalho. O meu mais sincero agradecimento e reconhecimento, de que essa conquista pertence também a to dos vocês. 


\section{SUMÁRIO}

LISTA DE FIGURAS $\quad$ ix

LISTA DE TABELAS $\quad \mathrm{x}$

RESUMO Xviii

1-INTRODUÇÃO 2

2-REVISÃO DE LITERATURA

2.1-PRINCÍPIOS DA OSSEOINTEGRAÇÃO

2.2-AVALIAÇÃO CLÍNICA DA OSSEOINTEGRAÇÃO 17

2.3-CRITÉRIOS DE SUCESSO DOS IMPLANTES OSSEOINTEGRADOS 26

2.4-ETIOLOGIA DAS FALHAS 33

2.4.1-FALHAS RELACIONADAS COM SOBRECARGA OCLUSAL 39

2.4.2-FALHAS RELACIONADAS COM PERI-IMPLANTITE 42

2.5-TRATAMENTO DOS IMPLANTES CARACTERIZADOS COMO FALHA 45

2.6-MANUTENÇÃO DOS IMPLANTES OSSEOINTEGRADOS 50

2.7-IMPLANTES Brånemark 64

2.8-IMPLANTES IMZ 115

2.9-IMPLANTES ASTRA TECH 119

2.10-IMPLANTES ENDOPORE 123

2.11-IMPLANTES ITI 127

2.12-IMPLANTES NAPIO 133

3-PROPOSIÇÃO 142

4-MATERIAL E MÉTODOS 144

4.1-MATERIAL 144

4.2-MÉTODOS 145

4.3-ANÁLISE DOS DADOS 160

5-RESULTADOS 164

6-DISCUSSÃO 198

7-CONCLUSÕES 225

REFERÊNCIAS BIBLIOGRÁFICAS 228

$\begin{array}{ll}\text { ABSTRACT } & 261\end{array}$ 


\section{LISTA DE FIGURAS}

Figura $\mathbf{n}^{\circ}$ 1-Sonda plástica (Premier, Perio Wise) utilizada para sondagem 149 de sulco peri-implantar.

Figura $\mathbf{n}^{\circ}$ 2-Medição da profundidade de sondagem do sulco peri- $\mathbf{1 5 0}$ implantar.

Figura $\mathbf{n}^{\circ}$ 3-Posicionadores individualizados por registro da mordida em resina. Os dois dos extremos para área posterior e o do centro para região anterior.

Figura $\mathbf{n}^{\circ}$ 4-Posicionador individualizado encaixado no suporte específico para a técnica do paralelismo.

Figura $\mathbf{n}^{\circ}$ 5-Vista intra-bucal do posicionador individualizado com mordida em resina.

Figura $\mathbf{n}^{\circ}$ 6-Aparato para radiografia periapical pela técnica do $\mathbf{1 5 5}$ paralelismo com o posicionador individualizado.

Figura $\mathbf{n}^{\circ}$ 7-Limpeza da superficie do implante com cureta plástica 157 (Implant-Prophy+).

Figura $\mathbf{n}^{\circ} \mathbf{8}$-Fratura do parafuso da prótese.

158

Figura n ${ }^{\circ}$ 9-Fratura do parafuso do intermediário.

Figura n 10: Gráfico com os valores da perda óssea média em milímetros entre o $1^{\circ}$ e $2^{\circ}, 2^{\circ}$ e $3^{\circ}, 3^{\circ}$ e $4^{\circ}$, e o $1^{\circ}$ e $4^{\circ}$ exames nas faces mesiais e distais, e o valor médio global.

Figura $\mathbf{n}^{\circ}$ 11: Gráfico com os valores da perda óssea média em milímetros entre o $1^{\circ}$ e $2^{\circ}, 2^{\circ}$ e $3^{\circ}, 3^{\circ}$ e $4^{\circ}$, e o $1^{\circ}$ e $4^{\circ}$ exames nas faces mesiais e distais, e o valor médio global. 


\section{LISTA DE TABELAS}

Tabela nº 1: Composição dos vários graus de titânio ${ }^{48}$. 10

Tabela n. ${ }^{\circ}$ 2- Tabela de quatro campos, proposta por ALBREKTSSON; 33 ZARB $^{13}$, em 1993.

Tabela n..$^{\circ}$ 3:Demonstração dos componentes que fraturaram das próteses fixas totais suportadas por implantes osseointegrados, durante período de avaliação de 10 anos, HENRY; BOWER; WALL ${ }^{90}$, em 1995.

Tabela n.` 4:Apresentação das necessidades de tratamento durante 109 10 anos de manutenção das próteses fixas totais suportadas por implantes osseintegrados, HENRY; BOWER; WALL ${ }^{90}$, em 1995.

Tabela n 6: Número e percentual de pacientes em relação ao sexo. 164

Tabela n7: Apresentação da idade máxima, mínima, média e desvio 164 padrão dos pacientes.

Tabela n8:Distribuição do número e percentual de pacientes 164 agrupados por faixas etárias.

Tabela n'9: Número e percentual de pacientes e número de implantes na maxila, mandíbula e total avaliados nos quatro exames.

Tabela n ${ }^{\circ}$ 10: Número de pacientes não-fumantes e fumantes.

Tabela $\mathbf{n}^{\circ}$ 11: Demonstração da média do número de cigarros e desvio padrão.

Tabela n 12: Distribuição do sexo em relação ao hábito de fumar submetidos a estatística pelo teste Pearson Chi-square. 
Tabela $\mathbf{n}^{\circ}$ 13:Apresentação do número e percentual de pacientes 166 submetidos ou não a enxerto ósseo e radioterapia.

Tabela n 14:Número de pacientes, e número e percentual de 166 implantes subdivididos pelo número de implantes por paciente.

Tabela $\mathbf{n}^{\circ}$ 15:Número de pacientes e implantes, subdivididos pelo 167 número de implantes por paciente na mandíbula, maxila, e maxila e mandíbula.

Tabela $n^{\circ}$ 16:Número de implantes classificados de acordo com a 168 tabela de quatro campos de ALBREKTSSON, ZARB, $1993^{13}$ nos quatro exames.

Tabela $\mathbf{n}^{\circ}$ 17:Percentual de implantes classificados de acordo com a 168 tabela de quatro campos de ALBREKTSSON, ZARB, $1993^{13}$, nos quatro exames

Tabela $\mathbf{n}^{\circ}$ 18:Apresentação do percentual de sucesso e falha dos 168 implantes, e estabilidade das próteses

Tabela $\mathbf{n}^{\circ}$ 19:Distribuição das falhas dos implantes nos pacientes, em 169 relação a localização, hábito de fumar, tipo de prótese, comprimento e ao momento de detecção desta, sendo removido ou adormecido.

Tabela n²0:Número de pacientes com implantes na maxila, 170 classificados de acordo com a tabela de quatro campos de ALBREKTSSON, ZARB, $1993^{13}$, no $1^{\circ}$ exame, e subdivididos pelo número de implantes por paciente.

Tabela $\mathbf{n}^{\circ}$ 21:Número de pacientes com implantes na mandíbula, 170 classificados de acordo com a tabela de quatro campos de ALBREKTSSON, ZARB, 199313, no $1^{\circ}$ exame, e subdivididos pelo número de implantes por paciente. 
Tabela n²2:Número de pacientes com implantes na maxila, classificados de acordo com a tabela de quatro campos de ALBREKTSSON, ZARB, $1993^{13}$, no $2^{\circ}$ exame, e subdivididos pelo número de implantes por paciente.

Tabela n²3:Número de pacientes com implantes na mandíbula, 171 classificados de acordo com a tabela de quatro campos de ALBREKTSSON, ZARB, 199313, no $2^{\circ}$ exame, e subdivididos pelo número de implantes por paciente.

Tabela n²4:Número de pacientes com implantes na maxila, 172 classificados de acordo com a tabela de quatro campos de ALBREKTSSON, ZARB, $1993^{13}$, no $3^{\circ}$ exame, e subdivididos pelo número de implantes por paciente.

Tabela $\mathbf{n}^{\circ}$ 25:Número de pacientes com implantes na mandíbula, 172 classificados de acordo com a tabela de quatro campos de ALBREKTSSON, ZARB, 199313, no $3^{\circ}$ exame, e subdivididos pelo número de implantes por paciente.

Tabela $\mathbf{n}^{\circ}$ 26:Número de pacientes com implantes na maxila, 173 classificados de acordo com a tabela de quatro campos de ALBREKTSSON, ZARB, $1993^{13}$, no $4^{\circ}$ exame, e subdivididos pelo número de implantes por paciente.

Tabela $\mathbf{n}^{\circ}$ 27:Número de pacientes com implantes na mandíbula, 173 classificados de acordo com a tabela de quatro campos de ALBREKTSSON, ZARB, 199313, no $4^{\circ}$ exame, e subdivididos pelo número de implantes por paciente.

Tabela n²8: Distribuição do número de pacientes pelo tipo de 174 prótese na maxila e mandíbula.

Tabela n²9:Número de pacientes com inflamação do tecido gengival 174 peri-implantar na maxila nos quatro exames. 
Tabela n³0:Número de pacientes com inflamação do tecido gengival peri-implantar na mandíbula nos quatro exames.

Tabela $\mathbf{n}^{\circ}$ 31:Número de fraturas da infra-estrutura da prótese 175 durante os quatro exames na maxila.

Tabela $\mathbf{n}^{\circ}$ 32:Número de fraturas da infra-estrutura da prótese 176 durante os quatro exames na mandíbula.

Tabela n³3:Número de parafusos do intermediário fraturados nos 176 quatro exames na maxila.

Tabela $n^{\circ}$ 34:Número de parafusos do intermediário fraturados nos 176 quatro exames na mandíbula.

Tabela $\mathbf{n}^{\circ}$ 35:Número de parafusos da prótese fraturados na maxila, 177 nos quatro exames.

Tabela n³6:Número de parafusos da prótese fraturados na $\mathbf{1 7 7}$ mandíbula, nos quatro exames.

Tabela $\mathbf{n}^{\circ}$ 37:Fratura do clipe da sobre-dentadura instalada na maxila 177 nos quatro exames.

Tabela n³8:Fratura do clipe da sobre-dentadura na mandíbula nos 178 quatro exames.

Tabela n³9:Fratura da prótese total na mandíbula, após instalação 178 da sobre-dentadura na maxila.

Tabela n 40:Fratura da prótese total na maxila, após instalação de 178 sobre-dentadura na mandíbula.

Tabela n41: Fratura da prótese total na mandíbula, após instalação 179 de prótese protocolo na maxila.

Tabela $n^{\circ}$ 42: Fratura da prótese total na maxila, após instalação de 179 prótese protocolo na mandíbula.

Tabela n 43: Distribuição da presença ou ausência de mobilidade da 179 prótese sobre implante na maxila. 
Tabela n 44:Distribuição da presença ou ausência de mobilidade da prótese sobre implante na mandíbula.

Tabela $n^{\circ}$ 45: Alteração na fonação, depois da instalação da prótese 180 sobre implante na maxila.

Tabela $n^{\circ}$ 46: Alteração na fonação, depois da instalação da prótese 180 sobre implante na mandíbula.

Tabela $\mathbf{n}^{\circ}$ 47: Presença de sintomatologia dolorosa depois da instalação 181 da prótese sobre implante na maxila.

Tabela n48: Presença de sintomatologia dolorosa depois da instalação 181 da prótese sobre implante na mandíbula.

Tabela $n^{\circ}$ 49:Presença de parestesia depois da instalação da prótese 181 sobre implante na maxila.

Tabela $n^{\circ}$ 50:Presença de parestesia depois da instalação da prótese sobre implante na mandíbula.

Tabela n51:Detecção do número de parafusos soltos em próteses 182 sobre implante da maxila necessitando de reapertamento.

Tabela n 52:Detecção do número de parafusos soltos em próteses 183 sobre implante da mandíbula necessitando de reapertamento.

Tabela n53:Registro do número de intermediários na maxila que 183 necessitaram de torque, por se apresentarem soltos

Tabela n54:Registro do número de intermediários na mandíbula que 184 necessitaram de torque por se apresentarem soltos

Tabela n55:Presença de desconforto muscular, depois da instalação 184 da prótese sobre implante na maxila.

Tabela n ${ }^{\circ}$ 56:Presença de desconforto muscular, depois da instalação 184 da prótese sobre implante na mandíbula 
Tabela n57:Detecção de dor na ATM, após a instalação da prótese na maxila

Tabela n58:Detecção de dor na ATM, após a instalação da prótese na 185 mandíbula.

Tabela $n^{\circ}$ 59:Necessidade de reembasamento da sobre-dentadura da 185 maxila

Tabela $\mathbf{n}^{\circ}$ 60: Necessidade de reembasamento da sobre-dentadura da 186 mandíbula.

Tabela $n^{\circ}$ 61: Detecção do número de parafusos na prótese sobre 186 implante da maxila, espanados ou com desgaste no encaixe, necessitando de troca

Tabela $n^{\circ}{ }^{62}$ :Detecção do número de parafusos na prótese sobre 186 implante da maxila, espanados ou com desgaste no encaixe, necessitando de troca

Tabela $n^{\circ}$ 63: Presença de desgaste na porcelana da prótese da maxila. 187

Tabela n64:Presença de desgaste na porcelana da prótese da 187 mandibula.

Tabela $n^{\circ}$ 65: Necessidade de reembasamento do clipe da sobre187 dentadura da maxila correspondendo.

Tabela $n^{\circ}$ 66:Necessidade de reembasamento do clipe da sobre188 dentadura da mandíbula

Tabela n67:Realização de ajuste oclusal em próteses suportadas por 188 implante na maxila

Tabela n68: Realização de ajuste oclusal em próteses suportadas por 188 implante na mandíbula 
Tabela n69: Distribuição do número de casos avaliados nos quatro exames, quanto ao valor mínimo, máximo, média e desvio padrão da profundidade de sondagem na vestibular (V) e lingual (L) dos implantes.

Tabela $\mathbf{n}^{\circ}$ 70: Distribuição do número de casos avaliados no primeiro exame, quanto ao valor mínimo, máximo, média e desvio padrão do nível de inserção sondagem na vestibular (V) e lingual (L) dos implantes.

Tabela $\mathbf{n}^{\circ}$ 71: Distribuição nos quatro exames do percentual de faces com presença e ausência de placa nas faces vestibulares (V) e linguais (L) dos implantes.

Tabela n ${ }^{\circ}$ 72: Distribuição nos quatro exames do percentual de 190 implantes com presença e ausência de sangramento a sondagem nas faces vestibulares e/ou linguais.

Tabela n'73: Distribuição nos quatro exames do percentual de 190 implantes com presença e ausência de edema nas faces vestibulares e/ou linguais.

Tabela n 74: Distribuição nos quatro exames do percentual de implantes com presença e ausência de alteração na coloração nas faces vestibulares e/ou linguais.

Tabela n 75: Distribuição nos quatro exames do percentual de implantes com presença e ausência de mobilidade entre dois instrumentos.

Tabela n 76: Distribuição nos quatro exames do percentual de implantes com presença e ausência de supuração nas faces vestibulares e/ou linguais.

Tabela $\mathbf{n}^{\circ}$ 77: Notas aferidas pelos pacientes ao tratamento com prótese sobre implante, em relação a função, estética e conforto na maxila e mandíbula 
Tabela n ${ }^{\circ 78:}$ Fator de correção e valores da perda óssea medida em 194-6 milimetros radiograficamente no $1^{\circ}, 2^{\circ}, 3^{\circ}$ e $4^{\circ}$ exames nas faces mesiais e distais.

Tabela $n^{\circ}$ 79: Valor da perda óssea média em milímetros entre o $1^{\circ}$ e $2^{\circ}, 2^{\circ}$ e $3^{\circ}, 3^{\circ}$ e $4^{\circ}$, e o $1^{\circ}$ e $4^{\circ}$ exames nas faces mesiais e distais, e o valor médio global. 


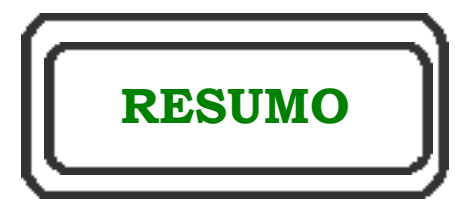




\section{RESUMO}

Nos últimos anos, têm sido possível a reposição de dentes ausentes, utilizando-se os implantes osseointegrados como suporte para próteses. A eficácia clínica desta terapia por implantes foi bem estabelecida por uma miriade de trabalhos longitudinais com alto índice de sucesso e suprindo critérios previamente estabelecidos. Nestes estudos, observou-se concentração das falhas desde a segunda cirurgia até o primeiro ano de instalação da prótese. Para a realização deste estudo foi avaliado o sucesso de implantes do sistema NAPIO (Núcleo de Apoio à Pesquisa de Implantes Odontológicos) confeccionados em titânio grau I e previamente tratados por ataque ácido. Foram inseridos 371 implantes em 109 pacientes suportando 135 próteses unitárias, parciais, protocolo e sobre-dentaduras, durante 2 anos. A distribuição por sexo foi de 39.4\% de homens e $60.6 \%$ de mulheres com idade variando de 17 a 82 anos. Os implante foram avaliados clinicamente através da profundidade de sondagem, nível de inserção, presença de placa, edema, supuração, alteração na coloração e radiograficamente pela técnica do cone longo padronizando a posição com o registro da mordida em resina acrílica. Os implantes foram classificados como sucesso se suprissem os critérios de SMITH; ZARB ${ }^{186}$. O índice de sucesso na maxila foi de $90.21 \%$ e $99.25 \%$ e na mandíbula de $95.90 \%$ e de $100 \%$, respectivamente, para os implantes e as próteses, compativel com os relatados na literatura. Detectou-se concentração das falhas até a segunda fase cirúrgica, com mais de $75 \%$ destas localizadas na maxila e superior a $55 \%$ na mandíbula. Todos os implantes que falharam apresentaram comprimento igual ou inferior a $10 \mathrm{~mm}$. As radiografias foram digitalizadas e medidas no programa Sigma Scan Pro, obtendo-se a perda óssea de 0.95 na face mesial, 1.03 na face distal e a média de 0.99 durante dois anos. A inflamação do tecido peri-implantar, presença de placa e sangramento a sondagem reduziram significativamente nos quatro exames. A medida de profundidade de sondagem e nível de inserção 
também diminuíram, porém de forma insignificante. A complicação, mais freqüente, da prótese foi o reaperto do parafuso da prótese, seguida da fratura deste. Os pacientes aferiram notas subjetivas, em relação ao conforto, estética e função da prótese suportada por implantes e a média das notas foi sempre superior a 9 na maxila e mandíbula. A partir dos dados obtidos com parâmetros periodontais, percentual de sucesso e falha, perda óssea mensurada radiograficamente, como também das complicações das próteses, concluiu-se que existe compatibilidade com os dados da literatura atestando a efetividade do sistema de implantes avaliado durante os dois primeiros anos . 


\section{1-INTRODUÇÃo}

A utilização dos implantes com finalidade de repor elementos dentários perdidos representa atualmente evolução considerável na Odontologia. Entretanto, desde os primórdios da história da humanidade, a reposição dos elementos dentários perdidos intriga e instiga a investigação do homem. Realizou-se, no decorrer dos séculos, diversas tentativas de substituição das unidades dentárias ausentes por materiais naturais ou sintéticos. Dentre estes materiais utilizou-se dentes extraídos, madeiras, rochas ígneas, ferro, ouro, tântalo, aço inoxidável, grafite, ligas de prata e outros. Na maioria dos casos, as aplicações in vivo estabeleciam a biocompatibilidade do material empregado. As reações do hospedeiro favoráveis ou adversas determinavam, respectivamente, o sucesso ou falha do procedimento ${ }^{130}$.

A pesquisa relacionada aos implantes odontológicos, durante muitos anos, permaneceu à margem da comunidade científica caracterizando-se pelo empirismo. Como resultado deste posicionamento, considerou-se com extrema suspeita os sistemas de implantes existentes, sendo estabelecido como improvável a reposição de unidades dentárias por fixações seguras, previsíveis e funcionalmente efetivas à longo prazo.

Os primeiros estudos relativos à efetividade dos implantes odontológicos tratavam-se de acompanhamentos a curto prazo de casos clínicos, sem respeitar os princípios básicos da pesquisa científica. Estes se fundamentavam na experiência clínica e opinião pessoal de alguns autores sem empregar parâmetros de avaliação nítidos, resultando em dados extremamente divergentes e de dificil interpretação. Nestes implantes objetivava-se conseguir estrutura similar à dos dentes naturais com ancoragem no tecido ósseo através das fibras do ligamento periodontal. A reprodução desta estrutura foi denominada com diversas nomenclaturas, como por exemplo, pseudoligamento, fibro-integração e osseointegração 
fibrosa. Este tratamento visando reproduzir a fisiologia dentária não apresentou, nos acompanhamentos a longo prazo, resultados baseados em critérios mínimos. A maioria dos trabalhos utilizava como principal critério de sucesso a permanência dos implantes na boca ou se estes se mantinham assintomáticos. Nestes, não se considerava as demais características associadas aos tecidos mole e duro adjacentes, tratando-se mais de conceito de sobrevivência dos implantes ${ }^{10,13,53}$. O desenvolvimento dos implantes osseointegrados se iniciou em 1952 e fundamentou-se em programa de pesquisa básica bem controlado e criterioso. Foram realizados estudos em animais sobre conformação macro e microscópica adequada, materiais biologicamente compatíveis e técnica cirúrgica apropriada de inserção das fixações. Estas experiências foram extrapoladas para humanos, por meio de investigações clínicas com registro de todos os implantes inseridos e análise meticulosa dos mesmos em acompanhamentos longitudinais. Estes obtiveram alto índice de sucesso a longo prazo, obedecendo critérios de sucesso previamente estabelecidos ${ }^{42,43}$. A seguir, os trabalhos foram reproduzidos em diversos centros de diferentes continentes, e o índice de sucesso se manteve similar aos iniciais. A partir desta evolução, a utilização de implantes realmente efetivos, seguros e previsíveis, se tornou realidade.

$\mathrm{O}$ advento dos implantes osseointegrados apresenta-se como solução plausível para determinadas situações clínicas, anteriormente consideradas com prognóstico sombrio e frustrante pelos profissionais. Dentre estas pode-se citar: doença periodontal com progressão rápida e extremamente destrutiva, resistente aos tratamentos convencionais; falhas endodônticas; próteses totais com adaptação estética e funcional inadequadas; envolvimento de unidades hígidas em reconstruções protéticas ou nos casos em que dentes remanescentes estão desfavoravelmente posicionados para suportar uma prótese. O paciente apresenta-se como maior beneficiado, já que anteriormente ao advento dos implantes osseointegrados em muitos casos as alternativas de tratamento 
não representavam exatamente o ideal de estética, conforto, e recuperação da capacidade mastigatória. Enfim, o desenvolvimento dos sistemas de implantes osseointegrados revolucionou o planejamento na Odontologia, aumentando o leque de opções disponíveis para o tratamento odontológico.

Inicialmente, a utilização dos implantes osseointegrados foi proposta unicamente em pacientes totalmente edêntulos. Gradualmente, extrapolou-se este planejamento para os parcialmente edêntulos e, por fim na substituição de elementos isolados. Paralelamente a este progresso, desenvolveram-se diversos sistemas de implantes visando obtenção da osseointegração. Atualmente diversos sistemas de implantes dentais preconizam a osseointegração, sendo necessária a comprovação a longo prazo da confiabilidade, utilizando-se critérios, parâmetros e protocolo de pesquisa rígidos.

$\mathrm{Na}$ Faculdade de Odontologia de Bauru da Universidade de São Paulo, o Núcleo de Apoio à Pesquisa de Implantes Odontológicos (NAPIO), desenvolveu sistema de implantes osseointegrados confeccionado em titânio grau I. A conformação macroscópica se apresenta similar a parafuso, sendo previamente submetido a tratamento ácido da superfície. Neste trabalho, foram avaliados a longo prazo, 109 pacientes com próteses suportadas por 371 implantes do sistema NAPIO. Durante 2 anos os implantes e as próteses foram monitorados clínica e radiograficamente, através de parâmetros incorporados em ficha clínica padronizada. Os dados obtidos foram enquadrados nos critérios de sucesso de SMITH; ZARB ${ }^{186}$, 1989 e comparados aos relatos literários de outros sistemas de implantes osseointegrados. 
2- REVISÃO DE LITERATURA 


\section{2-REVISÃO DE LITERATURA}

Os implantes podem se subdividir em endósseos (implantes circundados por tecido ósseo), subperiostais (infra-estrutura depositada na superfície do osso) e transósseos (implantes atravessando o interior do osso partindo da porção superior até a inferior). Atualmente os endósseos apresentam-se como os mais comumente utilizados. Dentre estes destaca-se os com forma similar à raízes, como parafusos, em detrimento dos laminados e subperiostais. Os implantes endósseos podem se inserir em um ou dois estágios cirúrgicos. No segundo caso, posiciona-se a porção da fixação no interior do osso permitindo cicatrização deste durante 3 a 6 meses; após este período realiza-se segunda cirurgia para instalação da porção coronal. Nos implantes de um estágio cirúrgico coloca-se a fixação no osso, e a porção coronal localiza-se na margem gengival sem recobrimento pelo tecido gengival, eliminando-se a necessidade da segunda fase cirúrgica ${ }^{140}$.

A revisão de literatura foi subdividida a fim de tornar a explanação mais didática nos seguintes tópicos: princípios da osseointegração; avaliação clínica da osseointegração; critérios de sucesso dos implantes osseointegrados; etiologia das falhas; falhas relacionadas com sobrecarga oclusal; falhas relacionadas com infecção; tratamento dos implantes caracterizados como falha e manutenção dos implantes osseointegrados. Por fim foram apresentados estudos de avaliação dos sistemas de implantes Brånemark, IMZ, ASTRA TECH, ENDOPORE, ITI e NAPIO. 


\section{1-PRINCÍPIOS DA OSSEOINTEGRAÇÃO}

Os atuais sistemas de implantes osseointegrados possuem base científica bastante sólida, em oposição ao empirismo antigamente existente. As pesquisas em animais, iniciadas no ano de 1952, por BRÅNEMARK ${ }^{42,43}$ e sua equipe, avaliaram longitudinalmente in situ e in vivo o comportamento do tecido ósseo na tíbia de coelhos, por meio da utilização de câmaras de titânio com sistema ótico. Observaram a circulação sangüínea na medula óssea, reação dos tecidos aos diferentes tipos de trauma e efeitos dos diversos tipos de agentes traumáticos no processo de reparo. No momento da remoção das câmaras de titânio instaladas na intimidade dos tecidos, estas não puderam ser removidas. Isto ocorreu devido à presença de intima interação entre microirregularidades do titânio e tecido ósseo. A partir desta observação, desenvolveram estudo inicial em cães na tentativa de se estabelecer protocolo cirúrgico apropriado para reabilitação de desdentados. Nestes animais, avaliaram cicatrização e estabilização mecânica de elementos protéticos suportados por fixações ancoradas no tecido ósseo. Foram utilizados implantes e elementos construídos em titânio puro com diferentes conformações. A partir dos resultados promissores dos estudos em cães sobre reparo dos tecidos e integração das fixações de titânio, desenvolveu-se modelo experimental em humanos. A interação entre tecido ósseo e superficie do implante, ou seja a obtenção da osseointegração, representou o ponto crucial da resposta clínica efetiva ${ }^{42,43}$.

BRÅNEMARK 42, em 1983, definiu osseointegração como: "uma conexão direta estrutural e funcional entre tecido ósseo normal viável e implante em função".

Ao nível da resolução da microscopia ótica, a osseointegração representa imbricamento direto entre tecido ósseo e superficie do implante, sem interposição de nenhuma camada de tecido mole. Subseqüentemente, investigações ao nivel ultra-estrutural pela microscopia eletrônica detectaram a existência de interface de 20 a 40 nanômetros de distância da superfície do 
implante preenchida por camada de proteoglicanas. Após esta, discerniu-se outra camada com filamentos colágenos organizados. As fibras colágenas estavam presentes na terceira camada situada aproximadamente 100 nanômetros da superfície de titânio ${ }^{9,13}$.

ALBREKTSSON, ZARB ${ }^{13}$, no ano de 1993, conceituaram osseointegração como processo através do qual a fixação de material aloplástico permanece imóvel e assintomática clinicamente e se mantém integrada ao tecido ósseo, após conexão da prótese e incidência das cargas oclusais.

O fenômeno da osseointegração ainda não se encontra completamente definido no contexto científico, entretanto o sucesso clínico longitudinal dos implantes como estruturas rígidas e seguras apresenta-se bem determinado. A pesquisa relativa à resposta da interface, provavelmente elucidará aspectos qualitativos e quantitativos desta206.

Para obtenção da osseointegração, deve-se conjugar diversos fatores que serão explanados a seguir 09,10,13, 42,43:

- Características relacionadas com o próprio implante

- metal empregado e sua camada superficial;

- energia superficial;

- rugosidade superficial;

- conformação macroscópica;

- Aspectos relacionados com as características ósseas da área em que será inserido o implante;

- - Utilização de técnica cirúrgica seguindo protocolo cirúrgico criterioso e rígido em duas etapas;

- Ausência de cargas prematuras entre estas duas fases. 
Em relação às características do metal, o titânio foi classificado pela ASTM (American Society of Testing and Materials) em 12 graus diferentes. Destes, os quatro primeiros seriam o que se convencionou denominar de Ti c.p. (Titânio comercialmente puro), e as graduações restantes seriam ligas metálicas. A tabela n. ${ }^{\circ} 1$ apresenta a composição das quatro primeiras categorias de titânio, sendo que pequenas quantidades de outros metais não são propositadamente incorporadas na manufatura. Durante a fabricação dos implantes deve-se eliminar ao máximo os elementos incorporados, obtendo-se composição muito próxima da pureza. Isto é necessário, pois muitos destes componentes poderiam atuar maleficamente no organismo humano, especialmente com período de contato prolongado. Pela sugestão destes possiveis efeitos cumulativos, opta-se usualmente por composição mais pura quanto possível. Além destas características, o titânio possui baixo índice de dissolução no corpo humano, alta tolerância pelo organismo e resistência à corrosão proporcionada pela sua estabilidade estrutural acentuada. Até mesmo em meios especiais como água salgada e cloro, o titânio apresenta quase absoluta ausência de corrosão. Esta resistência é provocada pela alta reatividade do titânio em contato com ar atmosférico, água ou eletrólitos formando camada de óxidos superficiais estável. Esta camada protege de maneira efetiva o titânio da corrosão. A conjunção das características do titânio lhe conferem a biocompatibilidade necessária à obtenção de contato íntimo e estável com o tecido ósseo 10,13,48. 
Tabela nº1: Composição dos vários graus de titânio48.

\begin{tabular}{|c|c|c|c|c|}
\hline \multicolumn{5}{|l|}{ Graus do titânio } \\
\hline COMPONENTES & I & II & III & IV \\
\hline Nitrogênio (máx.) & 0.03 & 0.03 & 0.05 & 0.05 \\
\hline Carbono (máx.) & 0.10 & 0.10 & 0.10 & 0.10 \\
\hline Hidrogênio (máx.) & 0.01 & 0.01 & 0.01 & 0.01 \\
\hline Ferro (máx.) & 0.20 & 0.30 & 0.30 & 0.50 \\
\hline Oxigênio (máx.) & 0.18 & 0.25 & 0.35 & 0.40 \\
\hline Titânio (aprox.) & 99.48 & 99.31 & 99.19 & 98.94 \\
\hline Resistência (MPa) & 170 & 275 & 380 & 485 \\
\hline Elongação (\%) & 24 & 20 & 18 & 16 \\
\hline
\end{tabular}


A camada de óxidos superficiais que recobre os implantes atua como fator determinante na interação entre osso e implante, e não o titânio propriamente dito. Apresentam-se duas interfaces nos implantes osseointegrados, sendo a primeira a interface peri-mucosa, na qual o tecido mole encontra o implante. A segunda, consiste na interface endóssea, na qual o osso alveolar contacta com o implante ${ }^{141}$.

As interações, ao nível molecular, entre superfície do implante e biomoléculas do tecido do hospedeiro, se refletiam diretamente nas reações detectadas ao nível microscópico. Estas interações consistiam no principal motivo da avaliação biológica das características da superfície dos implantes. Deve-se também ressaltar que fenômenos de biointegração acontecem entre área em neoformação do tecido ósseo e camada mais superficial do implante. A superfície deste se apresenta usualmente recoberta por óxidos, que não possuem a mesma composição do corpo do implante. O revestimento de óxido de titânio apresenta-se com carga elétrica compativel com células sangüíneas, como também a rugosidade superficial favorece migração celular para as microranhuras $08,10,13,42,43$.

A partir dos conhecimentos relacionados aos biomateriais, a interface do implante foi relacionada como um dos pré-requisitos para sucesso da fixação e manutenção do selamento da mucosa peri-implantar em volta desta. A falha em se obter ou manter este resulta na migração apical do epitélio em direção à interface osso-implante. Esta possivelmente evolui para completo encapsulamento da porção endóssea do sistema de implantes ${ }^{141}$. As características químicas da superficie do implante atuam de forma crucial na adesão e migração das células. A adsorção das proteínas sobre uma superficie constitui evento dinâmico com diversas variáveis determinantes. Dentre estas, ressaltou-se: tempo, química e estrutura da superfície, e função e concentração das proteínas em estudo. Cogitou-se a possibilidade de manipular estas propriedades futuramente, pela indução na predisposição de diferentes partes do implante se aderirem a determinados tipos celulares. Por exemplo, conformação do implante na porção cervical facilitaria migração e adesão de 
células epiteliais na fração mais superior e dos fibroblastos inferiormente, e na porção intra-óssea atrairia o tecido ósseo ocorrendo osseointegração ${ }^{08,48}$.

A tensão superficial mostrou-se intimamente relacionada com processo de reparo, atuando através da capacidade de maior ou menor quantidade de líquidos, como sangue e água, de se aderirem ao substrato. A esta capacidade denominou-se "molhabilidade". Com avaliação da inclinação das bordas de uma gota com o plano do substrato determina-se o grau de "molhabilidade". Quanto menor o ângulo interno da superficie da gota com o plano do substrato melhor se distribui a substância sobre a superficie. Em relação ao tecido ósseo, maior molhabilidade permitiu contato mais acentuado do sangue com microirregularidades superficiais do implante. Esta por sua vez, possibilitou formação de fibrilas colágenas e de calcificações em áreas mais próximas da superficie do implante. O titânio apresenta-se com valores de tensão superficial compativeis com os requisitos biológicos 13,48,147.

A rugosidade superficial produz microirregularidades, responsáveis pela indução do processo de cicatrização. Com esta, facilita-se a orientação por contato e, consequentemente, a habilidade de movimentação das células para esta superficie. Estes fatores aumentariam resposta tecidual e facilitariam imbricamento mecânico entre superficie óssea e microirregularidades do metal $13,48,147$.

Existem diversas formas de alterar a característica superficial do titânio criando microirregularidades superficiais ${ }^{48}$ :

- recobrindo com hidroxiapatita;

- aplicando "spray" de plasma de titânio;

- por corrosão ácida controlada;

- aplicando jatos abrasivos;

- realizando variações na técnica de usinagem.

Todos estes procedimentos tem por finalidade produzir microperfurações na superficie do implante. Estas aumentariam a rugosidade deste e favoreceriam indução do processo de cicatrização tecidual ${ }^{48}$. 
Macroscopicamente, a forma com roscas similar a parafuso, apresentou-se com ancoragem firme devido ao aumento inicial da superficie de contato entre implante e osso. Esta estabilidade inicial reduziu significativamente ocorrência de micromovimentos favorecendo posterior instalação da osseointegração $10,13,14,42,43,147$.

Além dos diversos fatores descritos, qualidade e quantidade apropriadas de tecido ósseo aumentariam a área de contato inicial entre implante e tecido mineralizado. LEKHOLM; ZARB ${ }^{128}$, em 1985, classificaram o leito receptor em relação à qualidade e quantidade de tecido ósseo, importantes para seleção de sítios de fixação dos implantes. A quantidade óssea foi classificada em cinco estágios diferentes, sendo primeiro estágio com maior quantidade e quinto com mais reduzida, tanto na maxila quanto na mandíbula. As seguintes categorias foram propostas:

A-Reabsorção mínima da crista residual;

B-Reabsorção moderada da crista residual;

C-Reabsorção avançada da crista residual, com presença somente do osso basal;

D-Reabsorção inicial do osso basal;

E-Reabsorção extrema do osso basal.

Em relação à qualidade óssea dividiu-se de acordo com a proporção entre osso cortical e medular, classificando-a em:

-Tipo I: constituído quase que completamente por tecido ósseo compacto e homogêneo;

-Tipo II: camada de cortical espessa envolvendo porção central de osso trabecular denso;

-Tipo III: fina camada de cortical óssea englobando área central de osso trabecular denso;

-Tipo IV: fina camada de osso cortical, em volta de tecido ósseo de baixa densidade trabecular e resistência reduzida.

Durante o procedimento cirúrgico, dever-se-ia realizar controle da temperatura, por meio da utilização de brocas novas e descartáveis com 
aumento gradual do diâmetro, irrigação abundante e baixa velocidade (máximo de $1600 \mathrm{rpm})$. Estes cuidados objetivariam obter menor dano ao tecido ósseo sem disseminação da necrose, proporcionando resposta tecidual máxima $01,13,48,147,199$.

Além disso, através de procedimento cirúrgico em duas fases, com ausência de cargas prematuras por período de 90 a 180 dias, se favorece a estabilidade inicial. Esta proporcionaria deposição celular adequada na superfície do implante e evitaria formação de tecido mole encapsulando-o. A micromovimentação excessiva, imediatamente após inserção do implante, interromperia repetidamente a seqüência de eventos da cicatrização óssea. Esta acarretaria na suplantação da cicatrização por cápsula de tecido fibroso, em detrimento da redução da aposição direta do tecido mineralizado, gerando processo de reparo. A ausência de micromovimentos favoreceria, então, cicatrização óssea apropriada, promovendo integração do implante ao osso $09,10,13,42,43,147,198$.

O procedimento cirúrgico para obtenção da osseointegração das fixações e de resposta adequada dos tecidos de proteção ao redor dos pilares, apresenta alguns requisitos gerais a serem respeitados propostos por ADELL et al. ${ }^{04}$, em 1990:

1-Condições de completa esterilização em sala cirúrgica totalmente equipada, evitando contaminação bacteriana na superficie do implante e tecido ósseo;

2-Técnicas padronizadas para inserção dos implantes e colocação dos pilares correspondentes;

3-Procedimento cirúrgico em duas etapas;

4-Implantes e pilares de fabricação correta com características definidas e preparo para eliminação de qualquer contaminante da superfície;

5-Avaliação e preparo correto do paciente.

A inter-relação de todos os fatores citados resultam em contato íntimo pelo imbricamento mecânico do tecido ósseo com microirregularidades 
da superfície do implante, antes deste entrar em função, possibilitando ocorrência da osseointegração 08,10,13,14,42,43.

O implante deve se apresentar clinicamente imóvel imediatamente após a inserção, durante a segunda cirurgia, e nas reavaliações subseqüentes antes e depois da colocação da prótese na fase de manutenção ${ }^{141}$.

A ausência de osseointegração na segunda fase cirúrgica pode se relacionar a diversos fatores. MEFFERT; LANGER; FRITZ ${ }^{141}$, no ano de 1992, ressaltaram as seguintes situações como passiveis de ocasionar a ausência de osseointegração:

1.O sistema submete-se às cargas oclusais prematuramente, ou seja, antes do período de 3 a 6 meses proposto;

2.Migração apical do epitélio no interior da interface e em seguida dos elementos do tecido conjuntivo. Com presença de mobilidade a encapsulação pelo tecido conjuntivo continua a se expandir em largura e aumenta a mobilidade.

3.Inserção do implante com pressão excessiva;

4.O implante não se adapta à dimensão da perfuração ocorrendo movimentação inicial entre implante e osso.

Além dos aspectos relacionados com a técnica cirúrgica, durante o planejamento, deve-se considerar número e disposição adequada das fixações para permitir distribuição uniforme das forças mastigatórias ${ }^{212}$.

Os sistemas de implantes necessitariam suprir diversos prérequisitos. Inicialmente, de acordo com LEMONS; NATIELLA ${ }^{130}$ em 1986, deverse-ia considerar a compatibilidade biológica do material utilizado e as condições peri-implantares. Os seguintes fatores foram relacionados:

1-O biomaterial deveria se apresentar mecânica e quimicamente limpo antes de ser inserido cirurgicamente; 
2-A conformação do implante deveria fornecer superfície adequada, para a transferência apropriada de forças sem provocar, entretanto, alterações biomecânicas significativas na interface entre implante e tecidos adjacentes;

3-A região peri-implantar deveria ser planejada para minimizar irritação aos tecidos moles circunjacentes, favorecendo manutenção da higiene bucal a longo prazo.

Segundo WEISS ${ }^{198}$, no ano seguinte, a determinação a longo prazo da osseointegração dependia de uma série de variáveis diretamente interrelacionadas:

1-A quantidade e qualidade de osso disponivel no leito receptor que o implante será inserido;

2-A magnitude, duração e direção da força aplicada favorecendo remodelação óssea em volta do implante inserido;

3-A conformação macro e microscópica do implante;

4-O padrão de integração tecidual em volta dos implantes;

5-Os materiais empregados e conformação das próteses suportadas por implantes.

6-Protocolo cirúrgico adequado consistiria em obrigação, e não uma variável, constituindo-se pré-requisito imprescindivel. Este englobaria seleção apropriada dos casos com planejamento cirúrgico e protético prévio, princípios de esterilização adequados, e inserção mais atraumática quanto possivel. 


\section{2-AVALIAÇÃO CLÍNICA DA OSSEOINTEGRAÇÃO}

Durante realização da segunda fase cirúrgica, pôde-se avaliar a obtenção da osseointegração clinicamente. A presença de mobilidade dos implantes constituiu-se indicação da ausência de osseointegração, de acordo com SMITH; ZARB ${ }^{186}$, em 1989. Esta mobilidade clínica se relacionaria com presença histológica de cápsula de tecido conjuntivo ao redor do implante. Quando ocorresse mobilidade, dever-se-ia obrigatoriamente remover o implante. Neste caso, este tende a se tornar cada vez mais sensível à percussão ou pressão, aumentando-se a mobilidade, levando à remoção inevitável do implante.

A mobilidade apresenta-se como parâmetro de baixa sensibilidade na detecção das falhas dos implantes. O contato íntimo entre osso e implante, sem presença de interface fibrosa entre estes determina imobilidade da fixação. Somente implantes com osseointegração completamente ausente ou nos fibroosseointegrados detecta-se mobilidade. Por isto, mobilidade apresenta-se como parâmetro de baixa sensibilidade e alta especificidade ${ }^{155}$.

O indice de MILLER foi proposto para avaliar mobilidade clínica entre dois instrumentos metálicos, utilizando-se de escala graduada de 0 a 3 , onde zero corresponde à imobilidade e demais valores a graus crescentes de mobilidade. Poderia se utilizar também avaliação por valores dicotômicos ( $\operatorname{sim} /$ não). Outro método de avaliação da mobilidade consistiria no som emitido pelo implante ao ser tocado por instrumento metálico, onde, nos casos em que a osseointegração foi bem sucedida o som resultante seria seco ${ }^{147}$.

Para detecção de baixos graus de mobilidade poderia se lançar mão de instrumentos como o Perioteste (Perioteste, Siemens AG, Bensheim, Alemanha). Este consiste de uma unidade eletrônica com visor, na qual se conecta fio flexivel com terminação em forma de bastão. Obtêm-se o grau de mobilidade através do contato da haste terminal com o implante, vibrando 4 vezes por segundo, durante 5 segundos. Após este período, o resultado final 
surge no visor através de escala de valores positivos e negativos, variando de -8 $\mathrm{a}+50$, sendo o maior valor correspondente à mobilidade mais acentuada e o menor à imobilidade do implante ${ }^{159}$.

A mobilidade e radiolucidez peri-implantar mensurariam aspectos similares da resposta do implante. Estes dois critérios se apresentaram usualmente interrelacionados, já que geralmente a mobilidade não se apresentou sem a existência de radioluscidez em volta do implante ${ }^{147}$.

O acompanhamento da radiolucidez peri-implantar e da perda óssea alveolar constitui-se fator crucial para preservação do implante. Este método de monitoramento possui a vantagem de não necessitar da remoção da prótese durante avaliação. A radiolucidez peri-implantar indicou presença de tecido conjuntivo interposto entre implante e osso, associada provavelmente à mobilidade do implante e conseqüente perda deste ${ }^{10}$.

A osseointegração consiste em definição histológica com repercussões clínicas e radiográficas. Quando detecta-se área de radiolucidez em radiografia convencional pela técnica do paralelismo, significa que já existe ausência real de osseointegração. As alterações ósseas iniciais não poderiam ser detectadas nas radiografias, constituindo-se em uma das desvantagens da técnica. Outra desvantagem seria deficiência de visualização das regiões vestibulares e linguais por tratar-se de imagem bidimensional de objeto tridimensional. Os requisitos básicos do emprego do acompanhamento radiográfico seriam, então, utilização de técnica padronizada de exposição e processamento dos filmes ${ }^{10,13}$.

GRÖNDAHL; LEKHOLM ${ }^{82}$, no ano de 1997, avaliaram valor prognóstico positivo das radiografias na identificação de implantes instáveis. A pesquisa se baseou em 2000 pacientes cujos implantes Brånemark foram acompanhados durante 3 anos. Neste grupo monitorou-se 79 pacientes com 413 fixações, nos quais foram radiograficamente detectados implantes supostamente caracterizados como falha. Efetuou-se os cálculos a partir do número de vezes que os pacientes foram atendidos $(n=482)$, já que alguns 
destes foram examinados mais de uma vez. Durante os primeiros três anos de acompanhamento detectou-se $90 \%$ das perdas. Nos resultados obtidos registrou-se valor prognóstico positivo de $83 \%$ na identificação radiográfica de implantes que falharam. Em 5\% dos casos a detecção se realizou unicamente com dados clínicos, sem identificação desta radiograficamente. Em 11\% dos casos removeu-se desnecessariamente a prótese, devido ao diagnóstico radiográfico impreciso. Concluiu-se que existe possibilidade de identificação radiográfica de implantes instáveis, quando realizado conjuntamente com exame clínico. Sugeriu-se que esta consulta de manutenção deveria se realizar pelo menos anualmente nos três primeiros anos, mantendo-se daí em diante de forma individualizada, quanto ao periodo necessário entre as consultas. Através da utilização das radiografias periapicais pela técnica do paralelismo para monitoramento de pacientes tratados por implantes osseointegrados objetiva-se avaliar condições do tecido ósseo peri-implantar, grau de perda óssea marginal e em alguns casos estado dos componentes mecânicos.

A radiografia tem sido utilizada para monitorar a perda óssea periimplantar durante a fase de manutenção dos implantes.

Em 1994, HOWSHAW; BRUNSKI; COCHRAN97, conduziram estudo com intuito de investigar se incidência de cargas mecânicas nos implantes e conseqüente propagação do estresse influenciaria o modelamento e remodelamento na interface osso-implante. Posicionou-se 2 implantes Brånemark em cada uma das 20 tíbias de cães e estes cicatrizaram durante 12 meses. Após este período submeteu-se implantes do grupo experimental a protocolo controlado de incidência de forças variando de no máximo $300 \mathrm{~N}$ e mínimo de $10 \mathrm{~N}$ durante 5 dias. O grupo controle permaneceu em estado de quiescência sem se submeter a nenhuma força. Doze semanas depois obteve-se cortes sem descalcificação e examinou-se através do microscópio eletrônico de varredura e ótico. Os dados morfométricos do grupo experimental foram avaliados e deduziu-se as seguintes tendências: 1. presença de perda óssea próxima à porção coronal da fixação; 2. redução no percentual de tecido mineralizado e detecção de marcadores da atividade óssea na interface óssea 350 micrômetros próxima ao implante. Os resultados obtidos suportaram 
premissa de que perda óssea observada na porção coronal de implantes submetidos à carga oclusal ocorre devido ao modelamento e remodelamento secundário aos microdanos ósseos provocados pelo protocolo de forças empregado.

Em 1995, ERICSSON e colaboradores ${ }^{73}$, analisaram características da mucosa peri-implantar de cães nos sítios expostos ao acúmulo de placa, durante pelo menos 9 meses. Inseriu-se 3 implantes em cada um dos 5 cães, 3 meses depois posicionou-se o intermediário, durante os próximos 3 meses realizou-se controle meticuloso da placa e no final deste período efetuou-se o exame inicial. Nos 9 meses subseqüentes permitiu-se acúmulo de placa nos implantes distais e higienizou-se mesiais e centrais. Depois desta etapa procedeu-se novo exame clínico e sacrificou-se os animais, obtendo-se cortes histológicos da área para análise histométrica e morfométrica. Na mucosa periimplantar dos sítios expostos ao controle de placa diário o tecido conjuntivo lateral ao epitélio juncional apresentou-se com ausência de células inflamatórias. Em oposição, depois de cessar-se o programa de higiene demonstrou-se presença de infiltrado na porção marginal da mucosa periimplantar. Na análise histológica do grupo controle e experimental revelou-se presença de infiltrado celular inflamatório adjacente à junção entre fixação e intermediário. Sugeriu-se que atuação deste infiltrado representasse resposta local do hospedeiro à presença de microrganismos entre fixação e intermediário. Hipotetizou-se que esta característica histológica expressaria a tentativa pelo hospedeiro de vedamento do espaço "infectado". Além disso, sugeriu-se que existência do infiltrado inflamatório circundando a junção fixação-intermediário pode explicar a perda óssea durante o primeiro ano subseqüente à instalação da prótese. Através da análise histométrica determinou-se: 1.crista óssea localizou-se entre 1 a $1.5 \mathrm{~mm}$ apicalmente à união fixação-intermediário; 2.presença de zona com aproximadamente $1 \mathrm{~mm}$ de altura de tecido conjuntivo normal não-infiltrado, este separa porção apical do infiltrado inflamatório da junção fixação-intermediário e crista óssea.

As alterações teciduais que acarretam perda do implante podem ocorrer de forma lenta, dificultando detecção precisa do momento em 
que aconteceu a falha. A partir da aparente similaridade morfológica clinica do tecido peri-implantar e gengival utilizou-se parâmetros clínicos periodontais no intuito de monitorar a longo prazo a saúde dos implantes. Ressaltou-se, entretanto, existência de controvérsias quanto a utilização dos índices periodontais na avaliação longitudinal dos implantes, em relação ao propósito e interpretação. Fundamentando-se nestes conceitos, alguns autores $02,03,20,54,56,72,92,104,124,167,169,196$ ressaltaram a necessidade de incluir parâmetros clínicos utilizados usualmente no diagnóstico da doença periodontal na avaliação dos implantes osseointegrados. Os seguintes parâmetros foram propostos 02,03,20,54,56,72,92,104,124,167,169,196 :profundidade de sondagem, nível de inserção, comprimento da gengiva ceratinizada, supuração, sangramento à sondagem, índices de placa e gengival.

A partir destes pressupostos, foi apresentado estudo prospectivo clínico de 9 anos por APSE e colaboradores ${ }^{20}$, em 1991, com os dados coletados em 46 pacientes. Avaliou-se 49 arcos completamente edêntulos, nos quais inseriu-se 238 implantes em 5 anos. Detectou-se falha de 21 fixações na segunda cirurgia, 8 implantes perderam a osseointegração em função e 8 permaneceram adormecidos. Registrou-se os seguintes parâmetros: indice de placa (SILNESS; LÖE, 1964183) e gengival (LÖE; SILNESS, 1963135), profundidade de sondagem com força controlada, presença da mucosa ceratinizada e medida da altura entre topo do intermediário e mucosa periimplantar. No decorrer dos nove anos observou-se redução do índice 0 de placa e aumento do valor 1; o índice gengival inicialmente concentrou-se no índice 1 com redução progressiva durante a avaliação. A presença de mucosa ceratinizada se registrou com valor médio de 1 correspondendo a $1 \mathrm{~mm}$ desta. As medidas da profundidade de sondagem foram obtidas, em relação a um ponto de referência situado no topo do intermediário. Esta reduziu-se de 4.27 $\mathrm{mm}(+1.2 \mathrm{~mm})$ no primeiro ano para $2.51 \mathrm{~mm}(+0.97 \mathrm{~mm})$ no nono ano. Sugeriu-se que esta redução na profundidade de sondagem pode representar diferença relevante no significado desta medida no acompanhamento de implantes, em comparação com o da doença periodontal, além da possibilidade da ausência de informação descritiva ou prognóstica. Concluiu-se, que não se registrou evidências de correlação estreita entre registro da falha do implante e 
presença de alterações da mucosa peri-implantar detectadas pelos parâmetros periodontais. Entretanto, monitoramento da inflamação da mucosa periimplantar e presença de placa mostraram-se como indicadores válidos quanto à cooperação do paciente com a higiene bucal.

Utiliza-se profundidade de sondagem comumente para se acessar saúde gengival, como também nivel de inserção conjuntiva ao redor do dente. Entretanto, o papel da sondagem ao redor dos implantes endósseos permanece indefinida. Partindo deste pressuposto, LANG e colaboradores ${ }^{125}$, no ano de 1994, objetivaram determinar nivel histológico de penetração da sonda em tecidos saudáveis e inflamados ao redor de implantes. Na amostra englobou-se 5 cães beagle, nos quais se inseriu na mandíbula, em um único estágio cirúrgico, 30 fixações ITI recobertas por spray de plasma de titânio. Após período de cicatrização inicial de 2 meses dividiu-se em três grupos: 1) mucosa peri-implantar sadia (3 cães); 2)mucosite experimental (3 cães); 3) periimplantite experimental induzida por ligadura (2 cães). Em 3 cães adotou-se o modelo boca dividida, sendo em um hemi-arco da mandíbula com higienização correspondendo ao grupo 1 e no outro como grupo 2 permitiu-se o acúmulo de placa induzindo-se a mucosite. Registrou-se os seguintes parâmetros no exame inicial, com 2 e 4 meses depois: profundidade de sondagem, nivel de inserção, indice de placa e índice gengival. Depois de 6 meses posicionou-se 60 sondas com força padronizada de $0.2 \mathrm{~N}$ e estas foram fixadas com acrílico nas faces $\mathrm{M}$ e D dos implantes. Foram obtidos cortes histológicos para análise histométrica. Obteve-se os seguintes valores, respectivamente, para o grupo 1, 2 e 3, índice de placa foi de $0.47,1.61$ e 1.96; indice gengival foi de 0.06, 1.61 e 2.05 e profundidade de sondagem clínica foi de $2.12 \mathrm{~mm}, 1.87 \mathrm{~mm}$ e $3.73 \mathrm{~mm}$. Nos resultados histológicos demonstrou-se identificação pela sondagem do nível de adesão do tecido conjuntivo no grupo 1 com média de erro de $-0.05 \mathrm{~mm}$ e no grupo 2 de $-0.02 \mathrm{~mm}$. Observou-se aumento na penetração da sonda nos sítios com presença de maior grau de inflamação, e no grupo 3 a sonda excedeu o nivel do tecido conjuntivo em média $0.52 \mathrm{~mm}$. Concluiu-se que a sondagem em implantes representa técnica acessivel para monitorar o estado dos tecidos peri-implantares. 
NEWMAN; FLEMING155, no ano de 1988, sugeriram que determinação da profundidade de sondagem apresenta-se aparentemente com especificidade e sensibilidade similar à mensurada no dente. Utiliza-se sondas estandartizadas plásticas para determinar profundidade de sondagem nos implantes. Em muitos destes este instrumento torna-se satisfatório quando se consegue alcançar o limite apical de sondagem peri-implantar. Entretanto, em alguns casos a conformação da fixação ou do intermediário não permite medidas precisas, porque a sonda não alcança o ápice da sondagem. Sendo assim, determinação da profundidade de sondagem pode ser subdimensionada gerando valor clínico falso negativo, ou seja baixa sensibilidade. Proporciona-se acesso mais preciso através da remoção da prótese favorecendo inserção da sonda paralelamente ao longo eixo da fixação. A localização precisa da ponta da sonda no fundo da bolsa ainda não foi esclarecida. Em implantes caracterizados como falha identifica-se usualmente bolsas profundas, entretanto a presença de profundidade acentuada não necessariamente significa falha da fixação. A espessura excessiva da mucosa do retalho durante cirurgia do intermediário geralmente influência a profundidade de sondagem. Nestes casos, durante o ato cirúrgico recomenda-se redução desta. As medidas de profundidade de sondagem apresentam alta especificidade, mas baixa sensibilidade na detecção de implantes que falharam. Apesar das indefinições relativas à profundidade de sondagem, este se apresenta como método fácil e rápido na detecção de alterações potencialmente deletérias no meio periimplantar.

$\mathrm{Na}$ sondagem de implantes foi proposta utilização de sonda periodontal na mensuração da distância do topo do intermediário até a margem gengival e da margem gengival até o fundo do sulco peri-implantar. Sendo que esta última referindo-se à medida de profundidade de sondagem e o nível de inserção sendo a soma das duas medidas obtidas, segundo BECKER et al. ${ }^{38}$, 1990. A medida do nivel de inserção apresenta-se facilitada nos implantes devido à presença de pontos de referência bem determinados. O registro deste parâmetro nas visitas de manutenção propicia a detecção precoce de possíveis alterações na mucosa peri-implantar. O diagnóstico nas fases iniciais pode 
favorecer a intervenção anteriormente à ocorrência de alterações irreversiveis ${ }^{155}$.

QUIRYNEN et al.168, em 1991, avaliaram confiabilidade da profundidade de sondagem comparando-a com dados radiográficos obtidos. Na amostra examinou-se 108 pacientes reabilitados na mandibula por sobredentaduras suportadas por 2 implantes Brånemark. Examinou-se a cada 6 meses durante 18 meses. Em cada consulta examinou-se 6 faces de cada implante com sonda do tipo Merrit-B (indicações de 1,2,3,5,7,8,9,10 mm) ou de força controlada (Peri-probe). Realizou-se bianualmente radiografias periapicais pela técnica do paralelismo, com finalidade de localizar nível do osso marginal. Detectou-se como média constante durante todo período de avaliação localização do nível ósseo radiográfico $1.4 \mathrm{~mm}$ apicalmente ao nível de inserção clínico. Obteve-se índice de correlação Pearson entre radiografias e sonda Merrit-B nas faces mesiais e distais de 0.67 e 0.61 , respectivamente, e com Peri-probe de 0.76 e 0.65 . A correlação mais acentuada se estabeleceu nos sítios com tecido peri-implantar sadio e ausência de crateras infra-ósseas. Nos registros duplicados da sondagem demonstrou-se desvio padrão intraexaminador de 0.40 para Merrit-B e 0.37 para Peri-probe, e média da diferença entre estas foi de $0.05 \mathrm{~mm}$. Concluiu-se que determinação do nível de inserção clínico consiste em indicador confiável do nível ósseo em volta dos implantes com saúde do tecido gengival.

Utilizou-se em diversos estudos $02,03,20,54,56,72,92,104,124,167,169,196$, os índices de inflamação e de placa peri-implantares como representativos dos indices gengival e de placa, de LÖE e SILNESS135 e SILNESS e LÖE183, respectivamente. Em relação à supuração, de acordo com MOMBELLI147, sua detecção a olho nu requereria grande quantidade de neutrófilos presentes, indicativos de inflamação peri-implantar mais avançada e não se relacionaria com o diagnóstico precoce das falhas.

WILSON et al.201, no ano de 1994, propuseram modelo de manutenção e acompanhamento da osseointegração, a partir da observação de parâmetros periodontais convencionais. Dentre estes, encontravam-se 
profundidade de sondagem, sangramento à sondagem, presença de supuração e limitando-se a alguns casos específicos exames microbiológicos. Em pacientes parcialmente desdentados, as reavaliações deveriam ser feitas no primeiro ano a cada 3 meses, e nos anos subseqüentes quanto mais comprometido o periodonto dos dentes remanescentes maior a freqüência das reavaliações. Nos pacientes parcialmente edêntulos com periodontite avançada, sugeriram em média três meses entre cada nova rechamada. Nos pacientes edêntulos, intervalos de três meses no primeiro ano, a fim de acompanhar os periodos iniciais da osseointegração, e nos anos subseqüentes anualmente. Além do acompanhamento clínico, aconselhou-se também monitoramento radiográfico anual dos pacientes utilizando técnica do paralelismo. A reavaliação da prótese deveria compreender remoção, pelo menos um vez ao ano, limpando-a e checando adaptação adequada do intermediário e parafuso de retenção. 


\section{3-CRITÉRIOS DE SUCESSO DOS IMPLANTES OSSEOINTEGRADOS}

A avaliação comparativa e detalhada dos diversos sistemas de implantes osseointegrados disponiveis e de seus respectivos índices de sucesso, devem se fundamentar em critérios de sucesso previamente estabelecidos observados durante a análise. É necessário conjugar praticidade, reproducibilidade e confiabilidade, em critérios discriminativos e sensíveis o suficiente para detectar alterações mínimas precocemente ${ }^{147}$.

Para que um implante seja considerado sucesso dever-se-ia preencher requisitos básicos, relativos à função mecânica, através da reabilitação da capacidade mastigatória, e à fisiologia dos tecidos mole e duro adjacentes. Com estes, objetiva-se a obtenção da osseointegração, manutenção da altura da crista óssea marginal e do tecido ósseo de suporte, além de aspectos relacionados com a saúde do tecido mole. Por fim, deveriam ser considerados aspectos psicológicos como ausência de dor, desconforto e inflamação, e satisfação pessoal. Esses critérios deveriam ser totalmente preenchidos para serem considerados sucesso, ou seja, se um dos prérequisitos não fosse suprido, o implante passaria a ser considerado como falha, a despeito de quão bem os demais critérios fossem preenchidos ${ }^{147}$.

$\mathrm{Na}$ maioria dos casos, o conceito de sobrevivência do implante confunde-se com o conceito de sucesso do implante, sendo muitas vezes utilizado com mesmo significado. Entretanto, o termo sobrevivência significa apenas que o implante instalado continua na boca do paciente, sem considerar qualidade de sua função e do tecido ósseo de suporte. A classificação de sucesso é utilizada naqueles que se encaixam em critérios estabelecidos e aplicáveis a todo implante inserido. O conceito de sucesso seria, portanto, por definição mais amplo e de maior valor para avaliação dos implantes osseointegrados $^{13}$. 
As primeiras recomendações abrangentes relacionadas aos critérios de avaliação dos implantes foram relatadas, em 1979, por SCHNITMAN; SHULMAN181. Estas regulamentações surgiram devido ao desenvolvimento de diversos sistemas de implantes osseointegrados, e o número cada vez mais elevado de tipos comerciais existentes. O NIH - National Institute of Health (Instituto Nacional de Saúde), organizou, então, a Conferência de Desenvolvimento dos Implantes Odontológicos, na Universidade de Harvard, em 1978, onde foram apresentados os seguintes critérios de sucesso:

1-Mobilidade menor do que $1 \mathrm{~mm}$ em qualquer direção;

2-Radiolucidez graduada, mas sem critério definido;

3-Perda óssea inferior a $1 / 3$ do comprimento vertical do implante;

4-Inflamação gengival passível de tratamento; ausência de sintomatologia e infecção; ausência de dano aos dentes adjacentes; ausência de anestesia, parestesia ou violação do canal mandibular, seio maxilar ou assoalho da fossa nasal;

5-Estar em função de acordo com estes critérios em $75 \%$ dos casos, por periodo mínimo de 5 anos.

Além disso, subdividiu-se os critérios em objetivos, subjetivos e determinantes da remoção do implante:

1-Critérios subjetivos:

1.1-Função adequada;

1.2-Ausência de desconforto;

1.3-Estética favorável;

1.4-Satisfação emocional e psicológica.

2-Critérios objetivos:

2.1-Perda óssea inferior a $1 / 3$ da altura vertical do implante;

2.2-Bom equilíbrio oclusal e dimensão vertical adequada;

2.3-Inflamação gengival passível de tratamento;

2.4-Mobilidade menor que $1 \mathrm{~mm}$ em qualquer direção; 
2.5-Ausência de sintomatologia e infecção;

2.6-Ausência de danos aos tecidos e dentes adjacentes;

2.7-Ausência de anestesia, parestesia ou violação do canal mandibular, seio maxilar ou assoalho da fossa nasal;

2.8-Tecido mole saudável;

2.9-Critérios de sucesso preenchidos em $75 \%$ dos casos ao final de 5 anos.

3-Critérios para remoção dos implantes:

3.1-Dor crônica;

3.2-Mobilidade significativa;

3.3-Infecção;

3.4-Perda significante e/ou progressiva do osso de suporte;

3.5-Fistula oro-antral ou oronasal;

3.6-Fratura óssea;

3.7-Problemas médicos e/ou psicológicos significantes;

3.8-Problemas com o implante incorrigiveis;

3.9-Possivel dano irreversivel aos dentes adjacentes;

3.10-Disestesias intoleráveis;

3.11-Problemas estéticos.

A Conferência também determinou alguns critérios relacionados aos estudos longitudinais de análise dos implantes odontológicos:

I-Abranger amostra significativa e representativa da população, conferindo confiabilidade à avaliação;

II-Ausência de resultados conflitantes entre diferentes investigadores.

Porém, ainda não havia sido apresentado até então nenhum estudo longitudinal, que suprisse os requisitos citados acima.

ALBREKTSSON et al. ${ }^{15}$, no ano 1986 , propôs os seguintes critérios de sucesso dos implantes: 
1-Imobilidade do implante individualmente, não-conectado à prótese, quando examinado clinicamente;

2-A radiografia não deveria demonstrar evidência de radiolucidez peri-implantar;

3-Presença de perda óssea vertical inferior a $0.2 \mathrm{~mm}$ anualmente, após o primeiro ano de utilização funcional dos implantes;

4-Ausência de sinais e sintomas irreversíveis e/ou persistentes, tais como: dor, infecção, neuropatias, parestesia ou violação do canal mandibular.

5-A partir do contexto exposto, percentagem mínima de êxito de $85 \%$ após 5 anos de observação e $80 \%$ ao final de 10 anos de acompanhamento.

Em 1988, o NIDR (National Institute of Dental Research) em conjunção com o NIH (National Institute of Health) ${ }^{156}$, organizaram nos Estados Unidos Conferência para estabelecer consenso sobre os implantes dentários. Nesta, participaram clínicos, educadores, pesquisadores e administradores. Diversos aspectos relacionados aos implantes foram discutidos, e alguns prérequisitos relacionados. Estes deveriam ser supridos em avaliação a longo prazo sobre efetividade de um sistema de implantes:

1- Acompanhamento de casos consecutivos;

2-Apresentar os objetivos do estudo com definição clara e precisa dos critérios de avaliação do sucesso ou falha;

3-Descrição da população em estudo e dos critérios de seleção dos pacientes;

4-Padronização com maior extensão possível das medidas dos resultados obtidos com o tratamento, aumentando a confiabilidade dos dados;

5-Seleção adequada do tamanho da amostra;

6-Relato de todos os pacientes que abandonaram a avaliação;

7-Registro de todas as falhas, desde a inserção dos implantes;

8-Documentação e acompanhamento de cada falha;

9-Utilização de métodos de análise padronizados; 
10-Evitar extrapolação dos dados a populações similares às do estudo sob condições experimentais parecidas.

Detectou-se número relativamente alto de implantes adormecidos, ou seja, que permaneciam submersos e não-conectados à prótese por se localizar em posição proteticamente desfavorável. Por este motivo, em 1989, SMITH; ZARB ${ }^{186}$, propuseram modificação dos critérios de ALBREKTSSON et al. ${ }^{15}$, de 1986, acrescentando que os implantes deveriam ser considerados sucesso se, além dos demais critérios previamente citados, também estivessem conectados à prótese de forma satisfatória para o paciente e para o dentista.

Em outra Conferência sobre Implantodontia realizada em Mainz na Alemanha, em 198953, diversos aspectos foram avaliados: materiais empregados nos implantes, sistemas disponíveis, seleção adequada dos pacientes, indicações apropriadas e diagnóstico pré-cirúrgico, considerações sobre o protocolo cirúrgico, material empregado nas próteses, manutenção dos pacientes e perspectivas futuras dos implantes. Além disso, foram relacionadas determinadas condições que devem ser preenchidas por um sistema de implantes:

1-Tempo de retenção em função adequado, demonstrado por testes experimentais e clínico;

2-Dano secundário mínimo, após perda do implante, requisito necessário à remoção deste prontamente;

3-Funcionalidade: características de fabricação, que permitam a confecção de prótese fixa ou removível funcionalmente eficiente, durante período suficientemente longo;

4-Praticidade: técnica cirúrgica mais simplificada possivel e confecção da prótese com mínimo de acessórios pré-fabricados com garantia de reabastecimento, após possiveis alterações do sistema;

5-Economia: custos razoáveis do equipamento básico, implantes e instrumentos. 
Além do emprego de critérios de sucesso bem definidos, para que se possa comparar os diversos tipos de implantes, é necessário estabelecimento de metodologia básica de pesquisa comum a todos os trabalhos. A avaliação científica de qualquer procedimento clínico deve seguir alguns princípios rigorosamente definidos. Inicialmente, o monitoramento clínico deve ser analisado de acordo com parâmetros quantificáveis. Estes devem ser reproduziveis por outros centros, sem incorporação de variações entre os diversos examinadores, obtendo-se resultados similares ${ }^{147}$.

Em 1990, ADELL et al.04 relacionaram a confiabilidade dos métodos de avaliação clínica dos implantes com os seguintes fatores:

I-Número de pacientes consecutivos suficiente e acompanhados continuamente;

II-Período de observação longo;

III-Protocolo estabelecido sem alteração por muitos anos, em relação às características básicas determinantes do prognóstico;

IV-Resultados reproduzidos por qualquer outro grupo, após treinamento adequado;

V-Publicado em revistas reconhecidas pela comunidade científica e com sistema de referência.

De acordo com ALBREKTSSON; SENNERBY10, em 1990, para correta avaliação dos implantes odontológicos, dever-se-ia obedecer a dez critérios mínimos em acompanhamento clínico:

1-Todo implante inserido deveria ser registrado e analisado;

2-O controle do paciente deveria ser realizado no mínimo anualmente e seguir critérios rígidos;

3-Toda saída de paciente deveria ser registrada, com relação ao tempo de acompanhamento e número de implantes;

4-Toda complicação deveria ser acompanhada e relatada;

5-Todas as avaliações deveriam ser realizadas de acordo com critérios de sucesso bem definidos; 
6-Medidas de altura óssea deveriam ser realizadas utilizando radiografias para os implantes individualmente, seguindo critérios rígidos de padronização radiográfica;

7-As reavaliações da estabilidade do implante deveriam ser feitas com a remoção da prótese;

8-Avaliação cuidadosa do tecido mole e seus resultados deveriam ser relatados;

9-Um implante que não preencha todos os critérios de sucesso seria considerado falha, a despeito da permanência ou não em função;

10-Toda falha e o tempo em que ocorreram deveriam ser relatados, independentemente de sua razão.

BUSER et al. ${ }^{46}$, em 1988, propuseram classificação das perdas como precoces se estas ocorressem antes da conexão da prótese, ou tardias se acontecessem após a instalação desta. Entretanto, independentemente do momento em que as falhas se apresentarem todo implante removido deveria ser obrigatoriamente registrado.

Segundo ALBREKTSSON; ZARB ${ }^{13}$, em 1993, os implantes também podem ser avaliados através de uma tabela de quatro campos, na qual se considera:

-Sucesso (Ss), aplicado aos casos devidamente testados em relação à imobilidade clínica, ausência de radioluscidez peri-implantar e aos critérios de sucesso adotados;

-Sobrevivência (S1), para os implantes que permanecessem em função, contudo sem mencionar avaliação clínica, ou radiográfica ou critérios de sucesso definidos; 
-Não computado (U), para aqueles que não comparecessem aos retornos por qualquer motivo;-Falha (F), aplicados aos que fossem removidos independentemente do motivo da falha ou remoção. Por exemplo, até mesmo perda de um implante em acidente deveria ser registrado como falha.

Tabela n. 2- Tabela de quatro campos, proposta por ALBREKTSSON; ZARB13, em 1993.

\begin{tabular}{ll}
\hline Ss & U \\
\hline S1 & F \\
\hline
\end{tabular}

\section{4-ETIOLOGIA DAS FALHAS}

A etiologia das falhas dos implantes pode se subdividir em traumática e infecciosa. Estes termos foram introduzidos no intuito de descrever dois fenômenos distintos clínica e microbiologicamente, de acordo com ROSENBERG; TOROSIAN; SLOTS ${ }^{175}$, no ano de 1991. Esta classificação se baseou na avaliação da amostra de 75 pacientes com 335 implantes. Em 11 pacientes detectou-se 32 implantes caracterizados como falha. Neste grupo, em 6 pacientes totalmente edêntulos registrou-se falha em 22 das 48 fixações e em 5 parcialmente edêntulos constatou-se 10 falhas em 34 implantes. A diferenciação se baseou na análise dos aspectos clínicos, microbiológicos e na fase em que as falhas ocorreram. Na caracterização clínica da etiologia infecciosa registrou-se sangramento, supuração, perda de inserção, dor, altos índices de placa e gengival, e presença acentuada de tecido de granulação durante intervenção cirúrgica. Nos casos classificados como etiologia traumática não se detectou nenhum destes sinais. Analisou-se microbiologicamente mediante microscopia por contraste de fase 
direta. Os implantes com etiologia infecciosa apresentaram-se com perfil bacteriológico de $42 \%$ de espiroquetas e formas móveis, e alguns periodontopatógenos (Porphyromonas gingivalis, Prevotella intermedia, Wolinella recta, Peptostreptococcus micros, Fusobacterium sp.). No perfil morfotípico das falhas por etiologia traumática detectou-se compatibilidade com áreas saudáveis obtendo-se predominância de Streptococcus. Quanto a fase de ocorrência das falhas, os implantes relacionados com etiologia infecciosa apresentaram-se entre primeira e segunda fase cirúrgica. Enquanto, as falhas dos implantes relacionados com etiologia traumática, após instalação da prótese. Sugeriu-se que caracterização microbiológica das falhas apresentase de grande valia para classificá-las de forma mais precisa em infecciosas ou traumáticas. Entretanto, cogitou-se possibilidade de uma etiologia suceder a outra e não se identificar corretamente a etiologia primária, especialmente quando estas ocorrem no primeiro e segundo estágio cirúrgico.

Pode-se classificar as falhas dos implantes a partir da época em que estas ocorreram, ou seja, antes ou depois da incidência de cargas oclusais, em respectivamente precoces ou tardias. As falhas precoces podem se ocasionar devido a infecção, doença sistêmica não diagnosticada anteriormente, cargas prematuras, fumo e trauma cirúrgico excessivo. As falhas depois da incidência de cargas oclusais podem ser estéticas ou protéticas. A falha estética resulta usualmente do planejamento deficiente ou desatenção à pequenos detalhes. Após a inserção da prótese as causas podem se relacionar com infecção ou sobrecarga oclusal. As forças incidentes nos implantes podem ser controladas através dos seguintes fatores: posicionamento do implante mais longo possivel; inserção do maior número de fixações e na inclinação adequada; estabelecimento de esquema oclusal harmônico ${ }^{35}$. 
No ano de 1994, WEYANT 199, investigou possivel associação entre variáveis correlacionadas com falha dos implantes e problemas nos tecidos moles peri-implantares. Na tentativa de identificar estas determinantes utilizou-se dados coletados durante 4 anos no Departamento de Tratamento de Veteranos, que inclui 172 centros médicos. A amostra foi de 598 pacientes, nos quais 2098 implantes de 16 tipos diferentes foram inseridos. O índice de sobrevivência destes foi de $96.1 \%$ sendo removidos 81 implantes. Os dados obtidos foram submetidos à análise estatística bivariada e regressão logística, correlacionando-se falhas e saúde dos pacientes com variáveis independentes. Os resultados demonstraram associação entre manutenção da osseointegração com sobrevivência dos implantes, devido a diversos fatores:

1-Estado médico do paciente;

2-Material da superficie que recobre o implante;

3-Protocolo cirúrgico adequado e complicações na cicatrização. A saúde dos tecidos moles peri-implantares se relacionou a:

A-utilização do tabaco;

B-superficie de recobrimento dos implantes;

C-experiência do profissional.

O tabagismo tem sido correlacionado com acentuada ausência de osseointegração nos implantes inseridos nos pacientes fumantes. Em 1992, SILVERSTEIN ${ }^{184}$, relacionou fumo com comprometimento da cicatrização tecidual. Ressaltou-se que efeitos deletérios do fumo advêm da presença de mais de 4000 constituintes tóxicos presentes nas fases gasosas e particuladas. Dentre estes sobressai-se a nicotina como toxina de maior interesse, além dos gases mais comuns: cianido de hidrogênio e monóxido de carbono. A nicotina atuaria como vasoconstrictor, reduzindo aporte sanguíneo na área, e por conseguinte dos nutrientes. Este efeito resultaria na isquemia tecidual e comprometimento significativo dos eventos cicatriciais. A nicotina também aumenta a adesividade das plaquetas, incrementando o risco de obstrução por trombos da microcirculação, resultando novamente em isquemia tecidual. Em adição, compromete-se com a nicotina proliferação das células vermelhas sanguíneas, fibroblastos e macrófagos. O gás monóxido de carbono atuaria na 
diminuição de transporte de oxigênio afetando o metabolismo. O cianido de hidrogênio se relaciona com inibição do sistema de enzimas necessário ao metabolismo oxidativo e transporte de oxigênio ao nível celular. A atuação conjunta destes efeitos adversos reflete-se na alteração do padrão de cicatrização nos pacientes fumantes. Sugere-se interrupção do fumo anteriormente à realização de cirurgias eletivas, durante pós-operatório cicatricial de traumas, doenças e cirurgias emergentes.

No ano de 1992, BAIN; MOY32, investigaram a influência do fumo no índice de falhas dos implantes. Utilizou-se amostra de 2179 fixações Brånemark consecutivamente posicionados em 540 pacientes. Os critérios para a detecção de falhas foram: remoção dos implantes com mobilidade e mais de $50 \%$ de perda óssea detectada radiograficamente. A percentagem geral de falhas foi de 5.92\%. Entretanto, estas se concentraram mais em fumantes $(11.28 \%)$, do que em não fumantes (4.76\%). Avaliando-se estes dados em relação aos sextantes, registrou-se percentual de falhas significativamente maior em todas as regiões dos fumantes, excetuando-se a porção posterior da mandíbula. Ressaltaram a atuação maléfica da nicotina na microvascularização, relacionando-a como mecanismo mais provável na indução das falhas. A partir deste pressuposto e dos dados apresentados, sugeriu-se interrupção do hábito de fumar durante as fases cirúrgicas dos implantes.

No mesmo ano, JONES e TRIPLETT ${ }^{111}$, avaliaram retrospectivamente 15 pacientes (5 fumantes e 10 não-fumantes) submetidos a enxerto ósseo autógeno simultaneamente à inserção de implantes, em relação aos possiveis efeitos adversos do fumo na cicatrização tecidual. Esta se apresentou comprometida em 5 dos 15 pacientes com perda óssea extensa e/ou dos implantes, neste grupo 4 pacientes fumavam no período préoperatório. Embora, outros fatores coadjuvantes possam influenciar os resultados obtidos o hábito de fumar consiste em fator de alto risco, sendo necessário controle deste no período pré e pós-operatório. 
DE BRUYN; COLLAERT59, no ano de 1994, avaliaram em estudo retrospectivo o efeito do fumo na falha precoce de implantes Brånemark, antes de se submeter a incidência de cargas oclusais. Na amostra englobou-se 452 fixações em 117 pacientes, sendo 208 na mandíbula e 244 na maxila. O índice de falha foi de $9 \%$ nos fumantes e $1 \%$ nos não-fumantes. Em $31 \%$ dos fumantes registrou-se implantes classificados como falha e em não-fumantes somente 4\%. Concluiu-se que fumo apresenta-se como fator significativo. Entretanto, este não se constitui no único fator importante na determinância da falha anterior a incidência de cargas oclusais. Recomendou-se realização de estudos prospectivos para acessar risco de falha dos implantes em conjunção com fumo.

GORMAN e colaboradores ${ }^{79}$, no ano de 1994 , relacionaram o efeito do fumo com sobrevivência de implantes até segunda fase cirúrgica. Analisouse amostra de 2.066 implantes inseridos em 310 pacientes do Departamento de Veteranos reabilitados por 433 próteses. Classificou-se implante como falha mediante presença de dor, mobilidade, infecção e radiograficamente radioluscência peri-implantar. Correlacionou-se falhas com história médica e dentária, e o único questionamento que apresentou-se relacionado com as falhas foi o fumo. Detectou-se nos pacientes fumantes $21.95 \%$ de falhas, em oposição aos não-fumantes com $8.77 \%$ de falhas.

BAIN, em 199631, comparou em estudo prospectivo resultados iniciais obtidos com 223 implantes Brånemark posicionados em 78 pacientes por um único cirurgião. Os pacientes foram divididos em três grupos: nãofumantes (NS), fumantes que seguiram o protocolo de cessar o hábito (SQ) e os fumantes que não interromperam o cigarro (SNQ). O protocolo de interrupção do hábito de fumar se iniciou 1 semana antes da cirurgia e nas 8 semanas após esta. O critério para classificar implantes como falha se baseou na remoção deste por qualquer motivo ou presença de mais de $50 \%$ de perda óssea Obteve-se os seguintes índices de falhas: NS (5.68\%), SQ (11.76\%) e SNQ $(38.46 \%)$ com $\mathrm{p}<0.05$. Registrou-se diferenças estatisticamente significantes no indice de falha do grupo SNQ, em relação a SQ e NS. Entretanto, os resultados dos grupos NS e SQ se apresentaram similares quanto aos indices de falha 
obtidos. Sugeriu-se as seguintes alterações induzidas pelo fumo como possivelmente atuantes: vasoconstricção local e sistêmica, redução no fluxo sanguíneo, aumento na agregação plaquetária, disfunção nos leucócitos polimorfomucleares, e especialmente a redução na vascularização do tecido ósseo. O protocolo de interrupção do hábito de fumar proposto no estudo se baseou no restabelecimento do fluxo sanguíneo do tecido ósseo uma semana depois deste. Concluiu-se, que o protocolo sugerido no estudo, demonstrou efetividade na redução dos índices de falha de osseointegração nos pacientes que seguiram as recomendações.

Em 1996, HAAS e colaboradores 87 , avaliaram em estudo retrospectivo a possibilidade de se correlacionar fumo e aparecimento de periimplantite. Então, comparou-se observações clínicas e radiográficas de 107 pacientes fumantes com 366 implantes, em relação à 314 não-fumantes com 1000 implantes. Os seguintes parâmetros foram registrados: indice de placa, indice gengival, profundidade de sondagem, hábitos dos fumantes, além de radiografias periapicais visando-se mensuração da perda óssea. O grupo dos fumantes apresentou-se com acentuação das seguintes variáveis: índice de sangramento, profundidade de sondagem, grau de inflamação da mucosa periimplantar e reabsorção óssea, detectada particularmente nos implantes localizados na maxila. Entretanto, não se estabeleceu esta correlação nos inseridos na mandibula. Sugere-se cessar o fumo especialmente durante o período pré e pós-operatório, assim como permanentemente devido aos efeitos sistêmicos e locais deletérios a longo prazo deste. Os achados clínicos apresentaram-se compativeis com comprometimento dos tecidos periimplantares, por conseguinte, detectou-se acentuação do risco ao desenvolvimento de peri-implantite nos fumantes. Ressaltou-se a necessidade de avaliações longitudinais com fumantes inativos, a fim de avaliar se os efeitos negativos deste hábito nos tecidos peri-implantares reverte-se em comparação com os fumantes ativos.

No ano de 1997, LINDQUIST; CARLSSON; JEMT133, observaram influência do fumo na perda óssea peri-implantar de 45 pacientes edêntulos com 266 implantes durante período de 10 anos. Desta amostra 21 fumantes e 
24 não-fumantes foram reabilitados por prótese fixa suportada por implantes. No exame incluiu-se mensuração da perda óssea radiograficamente, questionário detalhado sobre hábitos dos fumantes e registro do índice de placa. Os dados foram avaliados segundo modelo de regressão linear múltipla. Durante 10 anos foram removidos somente 3 implantes (1\%), sendo 2 na segunda cirurgia e um seis anos depois da colocação da prótese. A perda óssea média no período de avaliação foi de $\pm 1 \mathrm{~mm}$. Os fumantes com acúmulo de placa acentuado apresentaram-se com nível de perda óssea superior ao dos fumantes com índice reduzido de placa. Entretanto, no grupo de não-fumantes detectou-se ausência de acentuação no padrão de perda óssea com aumento no acúmulo de placa. A higiene bucal deficiente correlacionou-se com impacto significativo nos fumantes, o que não ocorreu nos não-fumantes. A perda óssea acentuou-se nos fumantes de forma diretamente proporcional ao número de cigarros.

\subsection{1-FALHAS RELACIONADAS COM SOBRECARGA OCLUSAL}

Correlaciona-se o termo sobrecarga com interação entre fatores mecânicos como magnitude, direção, dimensão e frequência da força, e biológicos como qualidade e quantidade óssea e habilidade de resposta celular. Estes fatores apresentam-se como determinantes críticos no estabelecimento de condições desfavoráveis da incidências de cargas promotoras de respostas adversas no tecido ósseo ${ }^{140}$.

No ano de 1994, ISIDOR99, avaliou histologicamente o osso periimplantar de macacos submetidos a sobrecarga oclusal e acúmulo de placa. Na amostra utilizou-se 4 macacos (Macaca fascicularis) e nas mandíbulas destes inseriu-se 2 implantes Astra Tech em cada hemi-arco. Após 6 meses, instalouse prótese parcial em um dos segmentos e o contorno oclusal desta apresentava-se com contato prematuro com o arco antagonista. Todas as semanas procedeu-se limpeza supragengival da prótese e subgengivalmente 
uma vez ao mês. No outro hemi-arco não se instalou prótese e se inseriu cordão de algodão, sem se executar nenhum método de higiene permitindo-se o acúmulo de placa. Após 18 meses em função, os animais foram sacrificados e obteve-se peças histológicas infiltradas e embebidas em resina acrílica para análise. Todos os implantes com acúmulo de placa apresentavam-se osseointegrados com perda óssea média de $2.4 \mathrm{~mm}$. Dos 8 implantes submetidos a sobrecarga oclusal somente 6 foram analisados histologicamente, pois 2 perderam completamente a osseointegração. Neste grupo, 2 apresentavam-se com ausência completa de osseointegração, 2 mantinham-se osseointegrados somente na porção apical e 2 osseointegrados e com perda óssea de 1.8 a $1.9 \mathrm{~mm}$. Concluiu-se que implantes submetidos a sobrecarga oclusal podem resultar em completa ou parcial perda da osseointegração histologicamente. Entretanto, nos implantes com acúmulo de placa exibiu-se sinais de peri-implantite com perda óssea marginal.

MEFFERT ${ }^{140}$, no ano de 1996, hipotetizou fatores relacionados com ausência de acomodação dos implantes ao estresse biomecânico excessivo. Ressaltou-se que implantes não se movimentam como os dentes e com sobrecarga podem ocorrer microfraturas irreversíveis. A área de superfície de suporte dos implantes se apresenta reduzida em comparação com os dentes, devido a inserção do ligamento periodontal. Nos dentes com presença de sobrecarga observa-se: hipertrofia do ligamento periodontal devido ao incremento na função; o volume de mineralização óssea pode se reduzir em volta do dente. Entretanto, na ausência de doença periodontal a situação pode se reverter, após eliminação ou redução das cargas excessivas.

Incidindo-se forças biomecânicas excessivas ocasiona-se estresse excessivo ou microfraturas na interface coronal osso-implante e promove-se perda da osseointegração na porção cervical da fixação. Sugere-se que as cargas parecem possuir influência acentuada e especialmente em cinco situações clínicas: 1.implante posicionado em osso de qualidade inadequada; 2.posicionamento da fixação ou número destas não favorecem transmissão de forças apropriadamente; 3.paciente possui padrão de função oclusal associado à parafunção; 4. ausência de adaptação precisa da infra-estrutura nos 
implantes; 5 .presença de cantilever longo demais sobrecarregando a ou as fixações. Deve-se ressaltar que a causa da perda óssea da crista peri-implantar pode ser multifatorial, e infecção bacteriana e fatores biomecânicos podem atuar de forma sinérgica. Cada fator deve ser previamente diagnosticado e eliminado antes de se iniciar o tratamento do sítio afetado. Outros fatores etiológicos podem atuar como co-fatores no desenvolvimento de problemas peri-implantares, tais como técnica cirúrgica traumática e resposta do hospedeiro comprometida por alterações sistêmicas ${ }^{99}$.

De acordo com PEREL 163, no ano de 1994, os hábitos parafuncionais possuem potencial destrutivo para os componentes da prótese suportada por implantes causando fadiga do metal. Entretanto, estes componentes apresentam-se passiveis de substituição. Contudo, ressaltou-se que ocorrência de várias fraturas de componentes sucessivos, podem causar danos cada vez mais graves ou até perda óssea peri-implantar comprometendo a osseointegração. Independentemente do tipo de material da fixação, as forças oclusais se propagam na prótese, intermediário e implante até o osso causando alterações biomecânicas variando da micromovimentação até sobrecarga. A regularidade e frequência de forças destrutivas se conjugam podendo ocasionar efeitos adversos, cumulativos e irreversiveis na prótese suportada por implantes. Recomenda-se utilização de placa miorrelaxante acrílica no arco com prótese mais estável, para pelo menos se dissipar as forças incidentes na prótese suportada por implantes, já que não se pode evitar a ocorrência do hábito parafuncional. Sugeriu-se a confecção da placa com dois tipos de acrílico, sendo o exterior (face oclusal) compacto, liso e plano proporcionandose resistência ao desgaste e facilitando o deslize dos dentes na superfície. Quanto a face interior, voltada para o dente, propôs-se a confecção com acrílico mais mole, levemente resiliente, gerando-se retenção friccional e efeito amortecedor na incidência das forças. 


\subsection{2-FALHAS RELACIONADAS COM PERI-IMPLANTITE}

Implantes dentais endósseos para se caracterizarem como sucesso devem obter selamento peri-implantar do tecido mole e ósseo em volta deste. A falha em implementar ou manter o selamento resulta na migração apical do epitélio na interface implante/osso e possível encapsulação do implante ${ }^{94}$.

Termos como implantes que falharam, falhas precoces e tardias e peri-implantite têm sido propostos com finalidade de designar estados patológicos relativos aos implantes osseointegrados e tecidos circunjacentes à estes. Esta terminologia ainda não apresentam-se com unanimidade acadêmica, além das discussões acerca da etiologia das falhas. Como também as informações pertinentes à biologia dos tecidos peri-implantares ainda não se encontram completamente elucidadas ${ }^{146}$. Sugere-se que alterações patológicas pertinentes aos tecidos moles peri-implantares devem se situar na categoria de doenças peri-implantares. As mudanças inflamatórias que apresentam-se confinadas aos tecidos moles em volta dos implantes podem ser definidas como mucosite peri-implantar. A associação entre perda óssea peri-implantar progressiva e lesão inflamatória dos tecidos moles circunjacentes aos implantes pode ser definida como peri-implantite. Esta se inicia na porção coronal do implante, enquanto a mais apical se mantêm osseointegrada. Clinicamente, o implante pode não se apresentar com mobilidade até o estágio final de progressão da perda óssea envolver completamente a fixação ${ }^{112}$. O diagnóstico e tratamento se baseia primariamente no contexto mecânico: distribuição de forças; estresse físico e mecânico; propriedades dos materiais; conformação macro e microscópica do implante e habilidade cirúrgica. Entretanto, problemas mecânicos podem provocar comprometimentos biológicos, como por exemplo fratura de um implante pode originar infecção 
bacteriana nos tecidos peri-implantares. No entanto, cogita-se possibilidade de fatores bacterianos iniciarem alterações teciduais sem causas mecânicas preliminares $^{146}$.

Ocasionalmente, registra-se destruição dos tecidos periimplantares durante fase de manutenção dos implantes. Desta destruição, pode se resultar na exposição da superficie do implante, ou das roscas deste previamente submersas no tecido ósseo. Esta destruição peri-implantar advêm do acúmulo de bactérias patogênicas, sendo denominada de peri-implantite devido à similaridades clínicas, microbiológicas e histológicas com a doença periodontal 98 .

MEFFERT ${ }^{140}$, no ano de 1996, revisou a literatura pertinente aos aspectos das peri-implantites questionando-se quanto às similaridades desta com a doença periodontal, além dos tratamentos disponiveis para esta. A partir da análise da caracterização microbiológica do sulco gengival e bolsa periodontal das unidades dentárias em comparação com o sulco e bolsa periimplantares, concluiu-se, que estas apresentam-se com muitas similaridades. Nos estados de saúde gengival, predomina-se os cocos, e nos processos patológicos grande número de patógenos Gram-negativos tanto nos dentes como nos implantes. Diferenciou-se microbiota dos pacientes parcial dos totalmente edêntulos reabilitados através de implantes osseointegrados. Nos primeiros observou-se padrão de patogenicidade mais acentuado, com presença especialmente de Gram-negativos e espiroquetas. Sugeriu-se possivel atuação das unidades dentárias como reservatório de microorganismos para colonização do sulco dos implantes. O tratamento das peri-implantites proposto foi por terapia regenerativa seqüenciado em descontaminação da superfície da fixação, enxerto ósseo e membrana. No processo de descontaminação propôs-se utilização de ácido cítrico a 40\% pH 1 durante 30 segundos. 
dos aspectos abordados salientou-se similaridade existente entre periimplantite e periodontite, em relação à etiologia e possiveis tratamentos.

No ano de 1997, SALCETTI et al. ${ }^{177}$, avaliaram aspectos clínicos, microbiológicos e relativos à resposta do hospedeiro em 21 pacientes com implantes caracterizados como falha. O grupo controle englobou 8 pacientes com implantes caracterizados como sucesso, além da inclusão dos sítios saudáveis dos implantes localizados nos pacientes do grupo experimental. As amostras de placa foram analisadas por sonda de DNA para 40 diferentes de microorganismos. O fluído gengival peri-implantar foi coletado e testou-se os niveis de alguns fatores catabólicos indutores da reabsorção óssea: prostaglandina $\mathrm{E}_{2}$, IL-1ß e IL-6. Além destes, citocinas anabólicas estimulantes da neoformação óssea como o fator de crescimento transformador-ß (TGF-ß) e fator de crescimento derivado de plaquetas (PDGF) foram analisados quanto à presença no fluído gengival. Detectou-se frequência acentuada, em sítios de implantes classificados como falha em comparação com os saudáveis, de P. nigrescence, P. micros, F. nucleatum ss vicentii e F. nucleatum ss nucleatum, assim como níveis significativos no fluído gengival de $\mathrm{PGE}_{2}$, IL-1ß e PDGF.

No ano de 1991, ZARB206, enfatizou em editorial a convicção de que doença periodontal e peri-implantar representam entidades distintas, justificando-se a partir da diversidade anatômica entre estas estruturas. A patogênese da doença periodontal improvavelmente se apresenta idêntica, ou à perda óssea gradual em volta dos implantes, ou na destruição da interface passivel de provocar a perda do implante. A premissa básica para esta negação se relaciona na diferença existente entre ligamento periodontal e interface ossoimplante. Enfatizou-se, que na ausência de ligamento periodontal, não existe doença periodontal. 
HICKEY e colaboradores ${ }^{94}$, no mesmo ano, ressaltaram que os implantes podem falhar em decorrência de processo infeccioso análogo à doença periodontal, embora nestes não exista ligamento periodontal.

\section{5-TRATAMENTO DOS IMPLANTES CARACTERIZADOS COMO FALHA}

O sucesso no tratamento de lesões peri-implantares depende de diversos fatores: severidade da perda óssea, morfologia do defeito e tipo de superficie que reveste o implante. Existe possibilidade de estacionar a progressão da perda óssea e em alguns casos regenerar o tecido ósseo reabsorvido ${ }^{61}$.

Com o desenvolvimento da peri-implantite a superficie do implante se expõe na cavidade bucal e se recobre por microorganismos. Com a terapia objetiva-se primordialmente restabelecimento da integração entre osso e implante. Entretanto, devido à presença das endotoxinas impede-se a aderência dos fibroblastos à superfície do implante. O tratamento destas áreas apresenta-se complicado, já que implantes não podem se submeter à raspagem e alisamento do cemento radicular preconizado nas unidades dentárias, com a finalidade de remover os microorganismos e os produtos destes. Nestes casos torna-se necessário descontaminação da superficie do implante proporcionando biocompatibilidade e osseointegração máxima. A fim de estabelecer o método de tratamento da superfície mais apropriado deve-se considerar dois fatores. Primeiramente, diversas superficies têm sido preconizadas com intuito de estimular e aprimorar a osseointegração do implante. Nestas deve-se considerar a facilidade na remoção dos contaminantes da superficie que recobre os implantes. Em segundo 
lugar, o tipo de superfície que recobre a fixação determina o tipo de tratamento descontaminante mais efetivo ${ }^{61}$.

Os microorganismos Gram-negativos compreendem porção significativa da microbiota dos casos de peri-implantite e produzem endotoxinas, especialmente os lipopolissacarídeos (LPS). Estes se relacionam com estímulo à resposta inflamatória aguda e reabsorção óssea em volta do dente ou implante. A superficie dos implantes exposta aos periodontopatógenos se contamina com endotoxinas, que podem atuar inibindo reparo das estruturas periodontais ou peri-implantares ${ }^{140}$.

No ano de 1997, NELSON et al. ${ }^{153}$, avaliaram afinidade de lipopolissacarideos (LPS) produzidos por Porphyromonas gingivalis e Escherichia coli, em relação ao titânio comercialmente puro de grau 1 e 5, com diferentes composições no óxido de superfície e rugosidades diversas. Utilizouse 48 discos com $10 \mathrm{~mm}$ de diâmetro e $0.8 \mathrm{~mm}$ de espessura, sendo 24 de titânio grau 1 e a outra metade de grau 5. Os discos foram novamente divididos em rugosos e lisos, em relação a, respectivamente, abrasão por jato de óxido de alumínio e polimento. Os discos foram incubados nos dois tipos de LPS durante 24 horas e lavados. Seqüencialmente, obteve-se a concentração deste após 24, 48, 72 e 96 horas de incubação. De acordo com os parâmetros deste estudo composição do óxido de superficie, rugosidade desta, tipo do titânio e do LPS não se influenciou adsorção dos lipopolissacarídeos nos espécimes testes. Entretanto, confirmou-se alta afinidade dos LPS à superfície dos biomateriais confeccionados com titânio.

No ano de 1992, MOMBELLI e LANG ${ }^{148}$, investigaram possibilidade de tratamento antimicrobiano de infecções peri-implantares associadas à microbiota subgengival similar à da doença periodontal. A amostra compreendia 9 pacientes parcial ou totalmente edêntulos reabilitados por implantes ITI. Nestes selecionou-se implantes com profundidade de sondagem igual ou superior a $5 \mathrm{~mm}$, amostras microbiológicas com $10^{6}$ Unidades Formadoras de Colônia ou mais e pelo menos 20\% de microorganismos anaeróbios Gram-negativos. No tratamento incluiu-se limpeza mecânica, 
irrigação com clorexidina a $0.5 \%$ e terapia antimicrobiana sistêmica utilizandose $1000 \mathrm{mg}$ de ornidazol durante 10 dias consecutivos. Após a terapia o sangramento à sondagem cedeu imediatamente, assim como nos 12 meses subseqüentes. A profundidade de sondagem apresentou-se com redução gradual significativa, excetuando-se um sítio que não houve remissão. Os parâmetros microbiológicos alteraram-se instantaneamente quantitativa e qualitativamente. Sugeriu-se que tratamentos objetivando redução da massa de microorganismos subgengival e supressão do segmento anaeróbio possui efeito benéfico em pacientes acometidos por peri-implantite.

No ano de 1993, GRUNDER e colaboradores ${ }^{83}$, avaliaram o tratamento de peri-implantite induzida em cães, através da regeneração tecidual guiada. Inseriu-se 2 implantes em cada um dos 10 cães beagle, cada implante da Screw-vent confeccionado em titânio possuía $7 \mathrm{~mm}$ de comprimento e $3.75 \mathrm{~mm}$ de dâmetro. Induziu-se durante 5 meses a periimplantite com inserção de ligaduras. Em 5 cães procedeu-se submersão do implante com remoção do intermediário e no outro grupo este foi mantido em posição. No grupo experimental, com implantes submersos e não-submersos foi realizado tratamento cirúrgico de defeitos ósseos com membrana de politetrafluoretileno expandido, e no controle somente cirurgia. Devido à exposição prematura das membranas, primeira a terceira semana, estas foram removidas no período variando de 4 dias até no máximo 4 semanas. $\mathrm{Na}$ avaliação dos parâmetros clínicos, não se demonstrou diferenças entre o grupo submerso e não-submerso, assim como em relação à formação óssea mensurada histológica e histomorfometricamente. Concluiu-se que nas condições de avaliação do estudo não detectou-se melhoria clínica ou histológica no padrão de formação óssea com utilização da regeneração tecidual guiada, e atribuiu-se este fato possivelmente à exposição prematura da membrana. 
Em 1993, JOVANOVIC112, sugeriu o tratamento em duas fases, quando a fator primordial da falha dos implantes consista no excesso de força biomecânica. A primeira fase se relaciona com avaliação da adaptação da prótese, do número e posicionamento das fixações e dos contatos oclusais. Em alguns casos, alterações na adaptação da infra-estrutura, inserção de maior número de fixações e promoção do equilíbrio oclusal podem estacionar progressão da lesão. A segunda etapa objetiva eliminar as bolsas periimplantares por procedimentos ressectivos ou regenerativos, associados à descontaminação da superfície do implante. Quando como fator causal diagnostica-se infecção bacteriana, na primeira fase controla-se a fase aguda desta e reduz-se inflamação dos tecidos circunjacentes. O tratamento engloba terapia antimicrobiana local e/ou sistêmica, além de incentivar o paciente em relação à manutenção cuidadosa da higiene bucal. Na segunda fase pode se executar terapia cirúrgica como no tratamento proposto para sobrecarga oclusal.

Em 1994, DENNISON e colaboradores ${ }^{61}$, avaliaram in vitro a interrelação entre superfícies dos implantes e efetividade de diversos tratamentos utilizados para descontaminação. A amostra foi de 36 implantes, sendo 12 recobertos por plasma de titânio, 12 por hidroxiapatita e 12 usinados. Preparou-se endotoxina radioativa (I125-LPS) a partir da Porphyromonas gingivalis, e os implantes foram recobertos por esta substância. Na fase seguinte fixações foram tratadas por bolinhas de algodão embebidas em água, solução de ácido cítrico, clorexidina a $0.12 \%$ ou por jato de ar abrasivo. Após o tratamento foi determinada radioatividade da endotoxina remanescente. $O$ ácido cítrico apresentou-se como mais efetivo sobre a hidroxiapatita, sendo similar nesta ao jato de ar abrasivo. A utilização do jato de ar abrasivo apresentou-se efetivo no tratamento de todas as superficies. Com a utilização da clorexidina não se removeu a endotoxina impregnada na hidroxiapatita. A água foi a substância com menor efetividade de todas as testadas. Os implantes usinados apresentaram-se como os mais descontaminados em comparação com as superficies recobertas por hidroxiapatita e plasma de titânio. Entretanto, ressaltou-se limitações dos estudos in vitro, primeiramente 
por não se estabelecer a quantidade de endotoxina que inviabilizaria ou afetaria a osseointegração in vivo.

Em 1995, HÜRZELER e colaboradores ${ }^{98}$, avaliaram e compararam o tratamento de peri-implantites induzidas pela inserção de ligaduras em cães beagle. Os defeitos ósseos peri-implantares foram mensurados e tratados: 1somente por desbridamento; 2-desbridamento associado à hidroxiapatita reabsorvida; 3-desbridamento juntamente à osso liofilizado desmineralizado proveniente de cães; 4-desbridamento em conjunção com a hidroxiapatita reabsorvida e regeneração óssea guiada; 5-desbridamento mais osso liofilizado desmineralizado de cães e regeneração óssea guiada. Avaliou-se das diversas modalidades de tratamento após 4 meses revelando-se como mais bem sucedida a regeneração óssea guiada, seguida dos enxertos ósseos e por fim desbridamento isolado. Não se obteve diferença estatisticamente significante comparando-se regeneração óssea guiada e a combinação desta com enxerto ósseo.

Em 1995, MELLONIG et al. ${ }^{143}$, relataram três casos de tratamento de implantes com perda de suporte ósseo significativo, entretanto estes apresentavam-se clinicamente imóveis. Determinou-se como causas das falhas combinação de injúria microbiológica, associada à sobrecarga oclusal. Os defeitos foram debridados e o tecido de granulação apresentava-se fracamente aderido à fixação. Então a superficie do implante foi descontaminada através da utilização de tetraciclina na concentração de $50 \mathrm{mg} / \mathrm{ml}$ (uma cápsula de $250 \mathrm{mg}$ diluída em $5 \mathrm{ml}$ de água estéril) durante 2 a 3 minutos. Em seguida inseriu-se osso desmineralizado liofilizado nos defeitos ósseos e recobriu-se estes com membrana de politetrafluoretileno expandida. Estas foram removidas após período de 6 a 8 semanas. Na avaliação clínica depois de 8 a 12 meses demonstrou-se substancial redução da profundidade de sondagem, ganho no nível de inserção e radiograficamente preenchimento do defeito. 


\section{6-MANUTENÇÃO DOS IMPLANTES OSSEOINTEGRADOS}

O sucesso a longo prazo dos implantes osseointegrados depende largamente da manutenção da saúde dos tecidos moles e duros periimplantares, além da distribuição apropriada das forças oclusais. A fim de prevenir problemas durante a fase de manutenção certos pré-requisitos devem ser obtidos e mantidos previamente. A osseointegração se relaciona diretamente com ato cirúrgico atraumático e posicionamento do implante em local proteticamente favorável permitindo distribuição das forças adequadamente. A saúde dos tecidos moles peri-implantares se estabelece através da associação entre confecção da prótese respeitando princípios básicos periodontais-protéticos e cooperação do paciente na remoção constante da placa ${ }^{112}$.

Durante a fase de manutenção o profissional pode se confrontar em alguns casos com situações mecânicas complicadas. Estas usualmente se caracterizam por reversibilidade, embora geralmente o tempo clínico do procedimento se torne longo ${ }^{36}$.

Examinou-se em estudo prospectivo por WALTON; MAC ENTEE197, no ano de 1997, ajustes, reparos, tempo necessário para realização destes e custos na manutenção de 69 próteses suportadas por 239 implantes. Acompanhou-se todos procedimentos realizados nas consultas de manutenção durante 12 a 48 meses depois da instalação da prótese. Definiu-se ajuste como qualquer tratamento que não envolvesse adição de material novo ou reposição de componentes ou materiais danificados ou desaparecidos, se algum destes fatos ocorressem denominava-se reparo. Nas próteses do tipo removivel o ajuste mais freqüente se consistiu no recontorno da prótese e reparo mais usual a reposição de componentes retentivos. Quanto às próteses fixas reaperto de parafusos e troca destes por fratura se apresentaram de forma mais assidua. Em cada prótese removivel se interviu 4 vezes mais para ajustes, quase 2 vezes mais para reparos, a duração da consulta foi mais longa e os custos em média $60 \%$ superiores, que as fixas na fase de manutenção. 
Relatou-se ocorrência repetida em alguns pacientes da perda ou fratura dos parafusos do intermediário ou da prótese. A ocorrência desta complicação se precipita geralmente a partir dos seguintes fatores: desadaptação da infra-estrutura e ausência de harmonia no esquema oclusal ou na função mastigatória. Além dos fatores citados, hipotetizou-se a possibilidade de atuação sinérgica destes com distribuição inapropriada das fixações no arco quanto ao número, comprimento, em linha reta ou angulação discrepante entre estas e ocorrência de hábitos para-funcionais $36,119,187,191$. A associação destes fatores pode atuar sinergicamente com hábito de bruxismo e se complicar mais ainda com angulação mais distalizada das fixações. Esta ocorre usualmente devido à concavidade lingual natural da mandíbula e posicionamento incorreto da fixação com a mandíbula aberta sem observar a relação oclusal com o arco oposto. A fusão dos fatores acima pode gerar mais correntes de força que o parafuso do intermediário possa suportar, fraturandoo36,187. Enfatizou-se que a negligência profissional com fraturas recorrentes dos parafusos pode resultar na ocorrência de complicações mais graves ${ }^{36,191}$.

Quando os implantes se apresentam distribuídos em arco e se aplicam forças estes se estressam em sentidos diferentes dissipando estas adequadamente. Com o posicionamento em linha reta qualquer força não-axial implica em sobrecarga da fixação ${ }^{36}$.

ROSEN 174, no ano de 1995, apresentou técnica objetivando a remoção de parafusos do intermediário fraturados no interior do implante. Comparou-se o prognóstico da fratura do parafuso da prótese com a do intermediário, estabelecendo-se como mais favorável a primeira. Isto se deve à possibilidade de substituição do intermediário, se o profissional não conseguir remover a porção fraturada do interior deste. Entretanto, a retenção do parafuso fraturado no interior da fixação pode acarretar no sepultamento deste. No caso apresentado inicialmente tentou-se rotacionar a porção fraturada utilizando-se duas sondas exploradoras para girá-la, mas o procedimento não foi bem-sucedido. Modificou-se um instrumental de ouro com ponta ativa similar a faca, reduzindo-se a lâmina para $1.25 \mathrm{~mm}$, sendo inferior ao diâmetro do parafuso e sem se danificar as roscas internas da fixação. A lâmina foi afiada com pedra de afiação nas duas faces, então inseriu- 
se o instrumento nas irregularidades do parafuso apoiando-o ou forçando-se confecção de canaleta de acomodação para rotacioná-lo com firmeza. Com muita destreza procedeu-se o giro gradual do instrumento apoiando-o com as duas mãos, quando o parafuso foi visualizado na porção hexagonal da fixação este foi apreendido por pinça hemostática e completamente removido. Sugeriuse que nos casos em que as roscas internas da fixação se danifiquem durante os procedimentos de remoção do parafuso, pode-se recorrer em última instância à utilização de intermediários cimentados, ao invés do sepultamento do implante e confecção de outra prótese.

Além da fratura dos componentes ressaltou-se a possibilidade de fratura da infra-estrutura. Como possiveis causas foram citadas: presença de defeito ou ausência de resistência do material empregado, espessura inadequada do metal empregado na infra-estrutura, áreas de solda sem resistência, distribuição inadequada do estresse e conformação inapropriada. A fratura da infra-estrutura pode ocasionar pequena mobilidade e acarretar na incidência de forças laterais excessivas nos intermediários fraturando também os parafusos deste ${ }^{119,191}$.

Relatou-se incidência rara da fratura das fixações, entretanto a ocorrência desta pode implicar em problema de difícil solução para o paciente e especialmente o profissional. Além deste aspecto, deve-se determinar etiologia e tratamento da fratura da fixação e isto pode apresentar-se extremamente complexo. Dividiu-se as possíveis causas para fratura da fixação em três: (1) defeitos oriundos da manufatura inapropriada da fixação; (2) adaptação inadequada da infra-estrutura da prótese; (3) sobrecarga oclusal. Os defeitos advindos de problemas na manufatura da fixação se relacionam com porosidade ou outros defeitos no metal desta, entretanto a ocorrência se apresenta extremamente rara. A segunda causa se relaciona com desadaptação da infra-estrutura resultando em incidência constante de força ao cisalhamento, como também de angulação do implante combinado com tensão axial ou compressão e torção. Freqüentemente nestes casos anteriormente à fratura da fixação se registra fratura dos parafusos da prótese ou do intermediário, sendo este sinal de importante validade como alerta para 
reavaliação profissional cuidadosa da prótese. A terceira causa apresenta-se com frequência mais acentuada do que as duas primeiras. A sobrecarga se relaciona primordialmente com hábitos parafuncionais e conformação da prótese. Citou-se como exemplo, forças oclusais exageradas oriundas de pacientes com hábito e conformação inadequada da infra-estrutura, particularmente nas excursões laterais com cantileveres posteriores. Neste caso proporciona-se situação favorável à fratura do implante por sobrecarga de forças laterais ${ }^{33}$.

No ano de 1996, BALSHI ${ }^{33}$, analisou 4.045 implantes com 3.75 $\mathrm{mm}$ de diâmetro em função, durante 5 anos. Nestes detectou-se $8(0.2 \%)$ fixações fraturadas em 5 pacientes. Em todas as fraturas registrou-se perda óssea marginal associada. Ressaltou-se que 6 das 8 fixações fraturadas suportavam próteses localizadas na porção posterior e em todos os pacientes com implantes fraturados associava-se presença de hábitos para-funcionais. A maior parte destes foram anteriormente atendidos com complicações relativas à fratura de parafusos da prótese ou do intermediário. Sugeriu-se que para prevenção da fratura da fixação em pacientes com hábito parafuncional deverse-ia adotar os seguintes procedimentos: inserção do maior número possível de implantes com o maior comprimento e diâmetro permitido pela anatomia óssea do paciente; evitar posicionamento das fixações com configuração em linha reta; minimizar ou eliminar cantileveres; reduzir contatos oclusais nas excursões laterais; utilização de placa miorrelaxante na tentativa de controlar ou amenizar os hábitos parafuncionais. Se houver porção da fixação com número de roscas internas remanescentes passiveis de conectar novo intermediário sugeriu-se a possibilidade de exposição cirúrgica e recontorno da fratura. Outras opções de tratamento foram apresentadas: adormecer-se a fixação fraturada ou inserção de mais uma fixação. Em qualquer das opções de tratamento citadas na fase subseqüente confecciona-se nova reconstrução protética. 
No ano de 1992, CHO; $\mathrm{CHEE}^{52}$, relataram caso clínico de intrusão do dente conectado rigidamente à prótese suportada por implante osseointegrado. Na mandíbula inseriu-se 6 fixações, sendo duas distalmente ao primeiro pré-molar esquerdo, duas anteriores e duas alternadas entre canino e segundo pré-molar direito. Na reconstrução fixa esplintou-se os implantes do hemi-arco esquerdo com encaixe de semi-precisão na face mesial da restauração. Na região anterior a reconstrução fixa de sete elementos englobou os dois implantes e o canino direito e o primeiro pré-molar esquerdo, que foram restaurados com encaixe na unidade mais distal da infra-estrutura. No hemiarco posterior direito reconstruiu-se com três elementos fixos suportados por dois implantes e um dente alternados através de encaixe na unidade mesial da infra-estrutura. Após a instalação da prótese, o paciente foi monitorado mensalmente e no quinto mês verificou-se discrepância evidente clinicamente entre a prótese e canino e segundo pré-molar esquerdo, o que não se verificou no primeiro pré-molar direito. A oclusão com o arco oposto manteve-se intacta suspeitando-se da intrusão dos elementos dentários. Justificou-se a aparente intrusão devido à diferença de resiliência entre o dente com presença de ligamento periodontal e implante rigidamente unido ao osso.

No ano de 1993, RIEDER; PAREL ${ }^{172}$, realizaram pesquisa com 45 profissionais, sejam clinicos ou especialistas, que trabalham com próteses suportadas por implantes osseointegrados. O grupo foi subdividido: profissionais que observaram intrusão (31) e os que não detectaram esta (14). Nos profissionais com 10 ou menos próteses suportadas por implantes confeccionadas registrou-se $27 \%$ de casos de intrusão e no grupo com mais de 100 próteses instaladas somente 3\%. Entretanto, ressaltou-se que esta observação não deve se apresentar como conclusiva. A maior parte dos casos de intrusão foi registrado no primeiro ano depois da instalação da prótese. O grau de intrusão variou usualmente de $2 \mathrm{~mm}$ a menos, mas em um caso registrou-se $12 \mathrm{~mm}$ de migração apical. Na maxila registrou-se incidência mais acentuada de intrusão nos dentes anteriores e pré-molares. Na mandíbula os pré-molares apresentaram-se com frequência de intrusão duas vezes superiores aos outros dentes. Relatou-se que a causa da intrusão origina-se provavelmente da conjunção de diversos fatores. Dentre estes citou-se os 
seguintes: atrofia do ligamento periodontal por desuso com encolhimento deste oriundo da rigidez da prótese que não transmite cargas ao implante; impacção alimentar no espaço entre o encaixe e o dente pode se iniciar a intrusão e desencadear fenômeno cíclico com aumento progressivo deste incrementando a impacção; memória de acomodação alterada devido à possibilidade da rigidez da conexão impedir esta memória no dente. Recomendou-se as seguintes condutas para evitar a intrusão das unidades dentárias: inserção do maior número de fixações possivel possibilitando reconstrução suportada unicamente em implantes; deve-se recorrer à junção de dentes a implantes na reabilitação protética somente quando o suporte das unidades se apresentar comprometido requerendo suporte adicional dos implantes, entretanto o mecanismo de encaixe deve apresentar-se com possibilidade de reversão se ocorrer a intrusão, além de comunicar ao paciente dos possiveis riscos; segmentação de próteses muito extensas em pequenas reconstruções com possibilidade de incluir modificações se ocorrer intrusão das unidades envolvidas nesta.

Em 1995, BIANCU; ERICSSON; LINDHE40, investigaram os tecidos periodontais de 10 cães beagle conectados a implantes osseointegrados. Em cada animal inseriu-se 2 implantes e subdividiu-os em dois grupos. No primeiro a prótese, conectando rigidamente 2 implantes a 1 dente através de esplintagem fixa com fio de ouro, foi instalada 1 mês depois da cirurgia do intermediário. O pré-molar contra-lateral foi utilizado como controle. No segundo grupo de 5 cães os cuidados com higiene foram interrompidos 1 mês depois da segunda cirurgia e inseriu-se ligaduras de algodão durante 4 meses. Depois removeu-se estas e realizou-se cirurgia excisionando-se os tecidos inflamados e o retalho foi reposicionado apicalmente aguardando-se cicatrização por 2 meses. Após este período o dente foi conectado aos implantes de forma similar ao outro grupo. Os dentes controle e teste foram avaliados seis meses depois através de radiografias e cortes histológicos. Nos resultados obtidos com as medidas histológicas revelou-se ausência de alterações marcantes, qualitativa e quantitativamente, nos tecidos do periodonto (gengiva, tecido conjuntivo supra-crestal e ligamento periodontal) dos dentes imobilizados. Sugeriu-se que os dados obtidos suportam biologicamente a 
utilização clínica de dentes conectados a implantes em reconstruções protéticas de pacientes parcialmente edêntulos.

No ano de 1998, PESUN e colaboradores ${ }^{164}$, avaliaram em cães a resposta histológica dos tecidos periodontais de dentes conectados rigidamente aos implantes através de prótese parcial fixa. Os dentes restaurados foram mantidos em função durante 6, 12, 18 e 24 meses, sendo sacrificados em cada período seis cães. Através da avaliação histológica detectou-se ausência de inflamação e estabilidade dos tecidos periodontais. Sugeriu-se que utilização de dentes conectados proteticamente a implantes não promoveu efeitos deletérios no periodonto, sendo suportados pela capacidade de adaptação destes tecidos.

Com a manutenção dos implantes objetiva-se primordialmente assegurar a integridade dos tecidos peri-implantares. Durante visitas regulares para manutenção dos implantes procura-se: 1.reduzir aporte de microorganismos; 2. verificar contatos erradicando possibilidade de estresse oclusal excessivo; 3.monitoramento da mucosa peri-implantar, detectando precocemente quaisquer alterações sugestivas da falha dos implantes ${ }^{112}$.

Em relação a saúde do tecido peri-implantar, questiona-se quanto a importância da presença de faixa de gengiva inserida circundando o implante. No ano de 1988, STRUB; GABERTHÜEL; SCHÄRER ${ }^{189}$, compararam implantes com ou sem gengiva ceratinizada na face vestibular, associado à presença ou ausência de placa bacteriana em cães. Foram inseridos dois implantes ITI em cada um dos três animais. Os seguintes índices foram registrados: indice de placa, condições gengivais, profundidade de sondagem, nivel de inserção, comprimento da gengiva inserida, posição da margem gengival e mobilidade do implante. Inseriu-se ligaduras de fios de algodão 7 meses depois da inserção dos implantes e a gengiva ceratinizada remanescente foi cirurgicamente removida. A área foi mantida cuidadosamente higienizada e três meses depois posicionou-se enxertos gengivais somente no lado experimental. Durante 5 meses realizou-se manutenção da higiene bucal e novamente inseriu-se ligaduras de algodão por 6 meses. O escore final foi obtido 11 meses depois da realização da cirurgia de enxerto. Não se registrou 
diferenças significativas entre os índices obtidos nos grupos controle e experimental, em relação à posição da margem gengival e nível de inserção sob influência das ligaduras. Nas áreas submetidas à enxerto gengival detectou-se aumento no comprimento de gengiva inserida, mas este não influenciou a posição da margem gengival e nivel de inserção.

Em 1992, MEFFERT, LANGER; FRITZ141, em artigo de revisão sobre implantes dentais comentaram acerca da importância da gengiva ceratinizada. A presença desta facilitaria higienização pelo paciente da área peri-implantar, além disso proporcionar-se-ia estética mais agradável nesta.

No mesmo ano, RAPLEY; MILLS; WYLAM ${ }^{170}$, relataram que os problemas relativos aos tecidos moles se originam usualmente dos seguintes fatores: quantidade inadequada de mucosa ceratinizada, mobilidade do tecido gengival enxertado, hiperplasia gengival, fïstula e gengivite. Foram citadas as técnicas disponíveis para aliviar ou eliminar estes problemas: enxerto autógeno livre de tecido gengival, retalho reposicionado apicalmente, redução da espessura gengival através de retalho ou gengivectomia e especialmente atenção redobrada ao controle da inflamação. As possiveis causas da hiperplasia tecidual se relacionam com intermediários muito curtos, resposta tecidual inadequada e mais freqüentemente inflamação tecidual crônica. A terapia destes casos envolve o posicionamento de intermediários mais longos, gengivectomia ou retalho excisionando-se o tecido hiperplásico. O tratamento das fístulas se relaciona geralmente com a junção intermediário-fixação responsável por área retentiva de placa bacteriana. Esta inflamação pode promover a perfuração do tecido e no tratamento inclui-se remoção do intermediário e excisão do tecido de granulação. Subseqüentemente, reposiciona-se o intermediário limpo e verifica-se a adaptação perfeita deste à fixação radiográfica e visualmente. O problema mais freqüente consiste na gengivite resultante invariavelmente da higiene bucal deficiente, devido à ausência de colaboração pelo paciente, acesso dificil e técnica inadequada. O tratamento deve incluir incentivo aos cuidados com higiene e diminuição no período entre consultas de manutenção. Nestes casos sugeriu-se recorrer à utilização de bochechos com clorexidina a $0.12 \%$. 
Relatou-se por TOLMAN, LANEY191, em 1992 como complicação mais freqüente no acompanhamento dos implantes osseointegrados a dos tecidos moles peri-implantares. Nestes casos registra-se com mais frequência a proliferação de tecido hiperplásico ou gengivite. Dentre as principais causas ressaltou-se a irritação tecidual crônica ou especialmente higiene bucal deficiente. O tratamento pode-se realizar de forma conservadora ou através de terapia cirúrgica.

No ano de 1993, ARTZI e colaboradores ${ }^{22}$, ressaltaram a importância da gengiva ceratinizada em volta dos implantes. A presença desta relaciona-se com manutenção mais fácil e menos vulnerável à inflamação nos tecidos peri-implantares. Sugeriu-se realização de enxerto gengival, a fim de facilitar manutenção dos hábitos de higiene bucal. A mucosa alveolar caracteriza-se pela delicadeza, sensibilidade acentuada à possiviveis agressões do meio externo e redução no selamento peri-implantar. Embora ceratinização isoladamente não se constitua em mecanismo impenetrável, esta confere resistência e estabilidade ao epitélio na manutenção da mucosa. Sugere-se a seleção dos pacientes a partir da ausência de gengiva inserida peri-implantar, vestíbulo desfavorável com atividade muscular submucosa e presença de mucosite peri-implantar constantemente. A técnica cirúrgica pode-se realizar antes da fase cirúrgica para inserção do implante, depois desta e anteriormente à fase protética ou após o término desta última. 
No ano de 1997, realizou-se fórum cujo questionamento consistiu110: se a fim de minimizar complicações, seria essencial que os intermediário dos implantes se apresentassem circundados por tecido ceratinizado. Os argumentos utilizados para defender a necessidade de gengiva ceratinizada circundando os implantes se basearam na criação de selamento peri-implantar por esta protegendo o tecido conjuntivo e ósseo das agressões do meio externo. Ressaltou-se no tecido peri-implantar a predominância de colágeno, número reduzido de fibroblastos e acentuado de células inflamatórias em comparação com o periodonto. Além deste aspecto, a comparação entre disseminação da inflamação entre dentes e implantes apresentou-se incrementada no segundo. Embora resultados a longo prazo dos implantes com tecido peri-implantar ceratinizado ou não tenham se apresentado similares, ressaltou-se outros fatores além dos citados acima a se considerar tais como: conforto e satisfação estética do paciente. Sugeriu-se a ausência de importância da gengiva ceratinizada peri-implantar baseando-se nos percentuais de sucesso obtidos a longo prazo com os implantes sem a presença destas. Salientou-se que gengiva ceratinizada não consistiria em elemento essencial e determinante do sucesso a longo prazo. Entretanto, a presença desta seria favorável, facilitando-se higienização e resistindo mecanicamente à possiveis agressões. Sugeriu-se que complicações associadas aos tecidos moles peri-implantares comparadas aos dos dentes podem se originar de mecanismos distintos de atuação.

Diversos estudos compararam utilização de diferentes tipos de instrumentos e possiveis efeitos destes na superficie do implante, a fim de manter a higiene peri-implantar em niveis adequados durante a fase de manutenção. 
Em 1988, WOLINSKY; CAMARGO; SEGHI203, examinaram a aderência in vitro do Actinomyces viscosus e Streptococcus sanguis ao titânio puro, em comparação à hidroxiapatita tratada. Ambas as superficies encontravam-se revestidas por saliva. Em relação à adsorção inicial do Actinomyces viscosus apresentou-se 5 vezes inferior na superficie de titânio em comparação com a de hidroxiapatita. O Streptococcus sanguis também apresentou adsorção diminuída no titânio, entretanto em menor grau que o Actinomyces viscosus.

No ano de 1990, KOUMJIAN; KERNER; SMITH ${ }^{121}$, relacionaram possiveis fatores contribuintes para o sucesso dos implantes: seleção criteriosa do paciente, conformação macro e microscópica da fixação, técnica cirúrgica precisa respeitando protocolo, conformação da prótese, manutenção da higiene bucal pelo paciente e revisão periódica pelo profissional. O intervalo entre as visitas deve-se estabelecer a partir de critérios relacionados com o paciente e a prótese. Nos itens relativos ao paciente ressaltou-se habilidade em higienizar os implantes, variação individual da resposta inflamatória e padrão de formação de cálculo. Em relação aos aspectos da prótese salientou-se o tipo e dimensão da prótese como fatores determinantes do intervalo das consultas de manutenção. Subdividiu-se a manutenção em três fases: pré-cirúrgica, cirúrgica e por fim protética e de manutenção. Anteriormente ao início do tratamento deve-se salientar para o paciente de forma enfática a importância da higiene bucal efetiva como elemento chave no sucesso dos implantes. Nesta fase ressaltou-se a necessidade do controle do paciente alcançando-se nível de higiene bucal aceitável antes do início do tratamento. Entre as duas fases cirúrgicas necessita-se de controles periódicos detectando-se quaisquer alterações precocemente. Após posicionamento do intermediário os cuidados de higiene bucal caseiros se intensificam e em certos casos recomenda-se utilização da clorexidina $0.12 \%$ para bochechos durante curto período de tempo e topicamente a longo prazo. Nesta fase os pacientes se iniciam no uso de tipos de escovas diferentes da tradicional, tais como, interdental e bitufo. Na última fase, durante confecção da prótese ministra-se instruções pertinentes à utilização de diversos tipos de escovas, de fio dental com passa fio ou o previamente montado durante a fabricação (Superfloss) e gazes 
cuidadosamente cortadas e friccionadas na superficie do implante. Sugeriu-se como técnica apropriada para utilizar o fio dental inserindo-se de vestibular para lingual e retornando para vestibular contornando-se o intermediário delicadamente, a fim de evitar-se forças excessivas nos implantes. Recomendase instruir-se enfática e cuidadosamente o paciente sobre a necessidade de associação de diversos métodos, de acordo com forma e posição dos intermediários a serem higienizados. Sugeriu-se o uso em casos selecionados de irrigadores bucais como método complementar, devido à fraca aderência da placa, verificada clinicamente, que deposita-se nos implantes. A utilização destes deve se realizar com cautela evitando-se danos ao tecido peri-implantar, através da utilização da pressão da água bem reduzida, angulação cuidadosa das pontas e direcionamento do jato horizontalmente e não verticalmente. Foi contra-indicada a utilização da ultra-som devido à possibilidade do metal e da vibração deste causarem danos à superficie riscando-a, da aderência do epitélio se romper com a cavitação e vibração inerentes ao ultra-som e da irrigação subgengival atuarem como disseminadores da infecção. A remoção dos depósitos de placa e cálculo efetua-se com curetas plásticas especialmente confeccionadas para este propósito. Necessita-se da substituição destes instrumentos após número limitado de usos, devido à perda da efetividade e esta se relaciona diretamente com quantidade e densidade do cálculo removido e à frequência na esterilização. Após a "raspagem" sugeriu-se a utilização de taças de borracha e pasta não abrasivas removendo todos os residuos de placa e polindo a superfície. Recomendou-se estabelecer o período entre as consultas de manutenção, a partir das observações registradas sobre a conduta do paciente desde o início do tratamento e da complexidade da reabilitação.

Em 1991, KWAN ${ }^{122}$, reportou os aspectos e procedimentos relativos à manutenção dos implantes osseointegrados. Nos procedimentos gerais englobou-se: incentivo à higiene bucal; visitas a cada 3 meses; radiografias periapicais a cada 6 ou 12 meses; inspeção cuidadosa dos tecidos periimplantares registrando-se possiveis sinais de inflamação; palpação detectando-se presença ou ausência de mobilidade na prótese, intermediário e/ou implantes; sondagem verificando-se o tônus tecidual e sangramento à sondagem. Na instrumentação dos implantes sugere-se o uso de instrumentos de teflon, plásticos ou recobertos por ouro. Deve-se evitar as curetas metálicas 
e ultra-som, devido à possibilidade de ranhuras na superficie do titânio. Depois deve-se proceder o polimento com taça de borracha e pasta profilática de granulação fina associada ao fio dental ou gaze. Em relação à educação do paciente deve-se instruí-lo sobre os riscos da utilização de objetos metálicos para higienização dos implantes. O elemento chave da instrução do paciente sobre os meios de higienização se relaciona diretamente com a efetividade alcançada. Para este fim sugeriu-se o uso destes: escovas uni e bitufo, fio ou fita dental com condutor, Super-floss, escovas interdentais, irrigadores bucais (Water-pik) e rinses bucais (Listerine, Peridex e outros) utilizados localmente. A partir das informações obtidas durante a visita de manutenção estabelece-se o próximo retorno.

No ano de 1992, KEAN; BERRY; CHILES ${ }^{117}$, determinaram a atividade antimicrobiana dos íons comumente detectados em implantes dentais. Os materiais testados foram os seguintes: titânio puro (Ti); liga de titânio (TiA = Ti:6Al:4V) e cromo-cobalto $(\mathrm{CC}=71 \%$ Co e $29 \%$ de Cr). Os microorganismos bucais incluídos foram os seguintes: Streptococcus mutans, Streptococcus sanguis, Staphylococcus aureus, Actinomyces naeslundii, Corynebacterium xerosis, Neisseria mucosa e Candida albicans. Detectou-se inibição microbiana excetuando-se a Candida albicans com concentração de Ti $(250-500 \mathrm{ppm})$ e TiA (500 ppm). Entretanto, se inibiu todos os microorganismos com concentração de $125 \mathrm{ppm}$ de CC. Sugeriu-se que a atividade antimicrobiana demonstrada neste estudo poderia aumentar as taxas de sucesso dos implantes, a partir da redução da concentração de bactérias no sulco peri-implantar e por conseguinte da possibilidade de inflamação. Entretanto, ainda não se elucidou se as concentrações dos íons atingem estes níveis nos tecidos peri-implantares e a possibilidade de repercussões sistêmicas. 
Durante os procedimentos de "raspagem" pelo profissional recomenda-se cuidado extremo para não riscar a superfície do implante. Se isto ocorrer aumenta-se a rugosidade e facilita-se o acúmulo de placa ${ }^{121}$.

No ano de 1992, McCOLLUM e colaboradores ${ }^{138}$, avaliaram in vitro a textura da superficie dos intermediários de titânio após o tratamento com curetas plásticas, sistema de jato abrasivo de bicarbonato e taça de borracha associada à pasta profilática de granulação fina, em comparação com grupo controle. Em humanos utilizou-se intermediários tratados como descrito anteriormente e se correlacionou com padrão de acúmulo de placa. A análise dos intermediários in vitro pela microscopia eletrônica de varredura não detectou rugosidade da superfície em todos os tratamentos empregados. No experimento clínico posicionou-se 4 intermediários, sendo um de cada tipo em 12 pacientes durante 7 dias. Após este período, removeu-se e avaliou-se os intermediários pela microscopia eletrônica de varredura. Determinou-se o percentual total da área de superficie do intermediário recoberta por placa bacteriana. O percentual médio da área de superficie de placa variou de $52,06 \%$ no jato de ar-bicarbonato e 55.29\% para as curetas plásticas. Todos os intermediários apresentavam-se com placa e todos os tratamentos proporcionaram superficies com percentuais bastante similares na quantidade de placa acumulada. A partir dos resultados obtidos recomendou-se a utilização de qualquer um dos tratamentos testados sem risco de danificar a superficie do intermediário. Clinicamente, evidenciou-se inefetividade das curetas plásticas na remoção de cálculos firmemente aderidos. Com sistema de jato de ar-bicarbonato abrasivo eliminou-se efetivamente placa, cálculo e manchas, além da fácil utilização com a prótese em posição.

No mesmo ano, AKAGAWA e colaboradores ${ }^{6}$, avaliaram clinicamente em 9 macacos as alterações no tecido gengival em volta de implantes endósseos de cristal-único de safira. Induziu-se o acúmulo de placa no grupo experimental (18 implantes) através da inserção de ligaduras nos implantes e dentes adjacentes. No outro quadrante, referente ao grupo controle, procedeu-se controle de placa durante 9 meses. Neste período no grupo experimental registrou-se aumento significativo nos seguintes 
parâmetros clínicos: índice de placa e gengival e profundidade de sondagem. Enfatizou-se a importância da ênfase no controle de placa na manutenção da saúde do tecido peri-implantar. Utilizando-se a taça de borracha com pasta profilática obteve-se superficie de intermediário mais lisa.

A seguir serão apresentados estudos sobre os seguintes sistemas de implantes: Brånemark, IMZ, Astra Tech, Endopore, ITI e NAPIO. Somente os sistemas de implantes que tencionam obter osseointegração serão considerados, porque a documentação destes apresenta-se superior aos sistemas anteriormente propostos.

\section{7- IMPLANTES Brånemark}

O sistema de implantes Brånemark consiste de um parafuso de titânio com superfície usinada, inserido em duas fases cirúrgicas. Na primeira cirurgia posiciona-se a fixação, e após período mínimo de 3 meses na mandíbula e 6 meses na maxila conecta-se o intermediário em segunda fase cirúrgica. Após o período de cicatrização tecidual inicia-se confecção da prótese definitiva ${ }^{02}$. Este sistema de implantes apresenta-se como dos mais difundidos e acompanhados, a seguir, serão relacionados diversos acompanhamentos clínicos dos mesmos.

Em 1981, ADELL et al. ${ }^{02}$ apresentaram acompanhamento longitudinal, com exame anual durante 15 anos (1965 - 1980) de 2768 fixações. Estas foram instaladas em 219 mandíbulas e 191 maxilas completamente desdentadas de 371 pacientes consecutivos. Destes, 38\% eram do sexo masculino e $62 \%$ do feminino, com idade variando de 20 a 77 anos. A avaliação dos procedimentos clínicos foi dividida em três períodos e grupos distintos: grupo de desenvolvimento (julho 1965-março 1968), quando o conhecimento experimental foi empregado em situações clínicas; grupo de rotina I (abril 1968 - junho 1971), durante o qual introduziu-se modificações ao método, advindas de diferenças entre as condições experimentais e clínicas; 
grupo de rotina II (julho 1971- setembro 1980), onde ajustes técnicos menores foram incorporados. Utilizou-se os critérios de sucesso de SCHNITMAN; SHULMAN ${ }^{181}$, de 1979 . Na maxila $48 \%, 81 \%$ e $88 \%$ das fixações instaladas permaneceram estáveis e na mandíbula $63 \%, 91 \%$ e $97 \%$, respectivamente para os grupos de desenvolvimento, 
rotina I e rotina II. Em relação à estabilidade das próteses registrou-se na maxila $79 \%, 89 \%$ e $96 \%$ e $100 \%$ na mandibula, respectivamente para os grupos de desenvolvimento, rotina $\mathrm{I}$ e rotina II. $\mathrm{O}$ acompanhamento radiográfico determinou que a perda óssea no primeiro ano foi em média de 1.2 $\mathrm{mm}$. Esta foi registrada predominantemente durante os períodos cicatriciais e de remodelação, isto é, desde a instalação da fixação até final do primeiro ano após conexão da prótese. Depois desta fase, houve diminuição da perda reduzindo-a para, em média, $0.1 \mathrm{~mm}$ ao ano. As falhas se concentraram no primeiro ano após inserção da fixação, e especialmente até segunda fase cirúrgica. Os tecidos moles marginais aos implantes se mantiveram clinicamente saudáveis, com média do índice de placa de $13.7 \%$, índice gengival de $7.6 \%$, e média de profundidade de sondagem de $2.6 \mathrm{~mm}$. Os resultados clínicos apresentados pelas próteses suportadas por implantes osseointegrados preencheram, e até excederam os critérios empregados nesta avaliação.

ADELL01, em 1983, relatou os resultados de 1961 implantes suportando próteses fixas em 300 mandíbulas ou maxilas totalmente edêntulas. Os pacientes apresentavam-se com idade variando entre 20 a 77 anos, sendo $60 \%$ do sexo feminino e $40 \%$ do masculino. A amostra foi dividida em quatro grupos distintos, de acordo $œ m$ o período de acompanhamento: grupo de desenvolvimento, observado durante 10 a 17 anos; grupo de rotina I, monitorado por 6 a 10 anos; grupo de rotina IIa, avaliado durante 5 a 6 anos; e o grupo de rotina IIb, observado por 1 a 4 anos. Utilizou-se os critérios de sucesso de SCHNITMAN; SHULMAN ${ }^{181}$, de 1979. Obteve-se índice de sobrevivência global de $81 \%$ na maxila e de $91 \%$ na mandíbula. A estabilidade das próteses acompanhadas na maxila foi superior a 90\%, e na mandíbula $100 \%$. Estes dados preencheram e excederam os critérios sobre sucesso dos implantes estabelecidos para este estudo. 
No mesmo ano, ZARB; SYMINGTON ${ }^{211}$ apresentaram os resultados obtidos com o tratamento de 12 mulheres totalmente edêntulas, na faixa etária de 32 a 68 anos, tratadas por próteses fixas suportadas por implantes. Inicialmente, inseriu-se 69 fixações, das quais 7 foram removidas no segundo estágio cirúrgico e três permaneceram adormecidas. Ao final dos 2 anos de observação, as doze pacientes possuíam reconstruções protéticas fixas suportadas por 59 implantes clinicamente imóveis.

Em estudo longitudinal no ano de 1986, ADELL et al.03, acompanharam e avaliaram reações dos tecidos marginais aos implantes Brånemark, por 3 anos. Instalou-se em 16 pacientes consecutivos totalmente edêntulos 95 implantes em 7 maxilas e 9 mandíbulas. Após segunda fase cirúrgica conectou-se sobre-dentaduras. Imediatamente depois desta fase, e após $6,12,21,30$ e 39 meses monitorou-se clínica e radiograficamente pela técnica do paralelismo. Registraram os seguintes parâmetros clínicos: presença de placa, gengivite, profundidade de sondagem, quantidade de gengiva inserida, e distância entre a prótese e o tecido gengival. No último exame, foram colhidas amostras microbiológicas e biópsias gengivais. A percentagem de intermediários sem placa foi de aproximadamente $70-75 \%$. Em relação à gengivite $80-85 \%$ dos intermediários apresentavam-se com tecido gengival periimplantar sem sinais clínicos de inflamação. A profundidade de sondagem média foi de $2.9 \mathrm{~mm}$ no exame final. Destas, aproximadamente $72 \%$ foi de 3 $\mathrm{mm}$ ou menos, $28 \%$ com 4 a $5 \mathrm{~mm}$, e nenhuma destas excedeu os $5 \mathrm{~mm}$. Detectou-se presença de gengiva inserida ao redor de aproximadamente $65 \%$ das superfícies dos intermediários por lingual e vestibular. Em relação ao osso marginal foi perdido $0.9 \mathrm{~mm}$ em média durante o primeiro ano e $0.05 \mathrm{~mm}$ nos dois anos subseqüentes. Detectou-se aumento na distância entre a prótese e o tecido gengival variando-se de 1.5 para $3.2 \mathrm{~mm}$ durante o estudo. No exame microbiológico, as 32 amostras apresentaram-se com $93 \%$ de cocos e 
bastonetes não-móveis Gram-positivos. Nas 14 biópsias de tecido mole, 35\% possuíam características de normalidade, e em 29\% observou-se somente inflamação reduzida. Não demonstrou-se nenhuma correlação constante entre as alterações ou valores dos diversos parâmetros clínicos, radiográficos, microbiológicos ou histológicos registrados. Verificou-se que mudanças mais significativas dos tecidos moles e duros ocorreram durante primeiro ano após conexão do intermediário. Concluiu-se que o prognóstico dos implantes apresentou-se extremamente favorável, devido às reações mínimas dos tecidos moles à microbiota presente e às alterações reduzidas da altura óssea detectadas radiograficamente.

No mesmo ano, foram relatados por ERICSSON et al. ${ }^{72}$, os resultados da avaliação clínica de próteses fixas suportadas pela combinação de dentes e implantes Brånemark. Foram incluídos dez pacientes parcialmente edêntulos, sendo 7 homens e 3 mulheres com idade entre 37 a 60 anos. As fixações foram inseridas em posições estratégicas e utilizadas como suporte para prótese em combinação com os dentes remanescentes. Em 6 dos 10 pacientes, o intermediário da fixação foi conectado rigidamente aos dentes, enquanto que no restante dos pacientes, utilizaram encaixes. O período de avaliação variou de 6 a 30 meses, com controles a cada 3 meses, de acordo com os seguintes parâmetros: higiene bucal, condições gengivais, profundidade de sondagem e nível do osso marginal acessado radiograficamente pela técnica do paralelismo. Os indices de placa e sangramento à sondagem se apresentaram, tanto no dente quanto na fixação, com diferença estatisticamente insignificante. A média da profundidade de sondagem nos implantes foi de $3.3 \mathrm{~mm}$, e no dente de $2.3 \mathrm{~mm}$. O nível do osso marginal diminuiu em quase todas as fixações, mas na maior parte destas a redução se apresentou inferior a $1 \mathrm{~mm}$. A partir dos dados obtidos, concluíram que não existiam diferenças clinicamente significantes nos pacientes parcialmente edêntulos, em relação à função e reação tecidual nos dentes e implantes, quando utilizados conjuntamente em reconstruções protéticas.

Foram apresentados, ainda neste mesmo ano, por HENRY; ADLER; WALL 89 dados relacionados à reabilitação de mandíbulas totalmente edêntulas 
de 16 pacientes com idade entre 29 a 73 anos. Foram inseridos 83 implantes Brånemark e as próteses suportadas por estes foram acompanhadas durante 2 anos. Posteriormente à conexão das próteses, os pacientes foram monitorados clinicamente e por radiografias periapicais pela técnica do paralelismo após 2 e 6 meses, e depois a cada 6 meses. Nenhum dos implantes foi perdido, suprindo o critério de imobilidade proposto neste estudo e apenas um deles permaneceu adormecido por se localizar em posição proteticamente desfavorável. Ao final do estudo, 82 fixações suportavam 16 próteses fixas. A média de perda óssea marginal anual radiográfica foi de $1.5 \mathrm{~mm}$, sem evidência de radioluscidez ao redor dos implantes.

COX; ZARB56, em 1987, relataram a utilização de implantes Brånemark em 26 pacientes, 5 homens e 21 mulheres, com idade entre 20 e 69 anos. Todos os indivíduos da amostra eram totalmente edêntulos, sendo instalados 161 implantes na mandíbula acompanhados por 3 anos. A avaliação iniciou-se de 1 a 3 meses após a conexão da prótese, e os seguintes índices foram registrados: dimensão da gengiva inserida, presença de placa, profundidade de sondagem, inflamação gengival e mobilidade. Além disso, realizou-se tomadas radiográficas periapicais pela técnica do paralelismo no ato da colocação do intermediário e depois anualmente. Pelo menos 50\% das superficies dos implantes apresentaram-se sem presença de gengiva ceratinizada. A percentagem de superficies com placa diminuiu significativamente durante os 3 anos. O índice gengival permaneceu estável em aproximadamente $30 \%$ dos sítios. A média da profundidade de sondagem foi de $3.6 \mathrm{~mm}$ entre o primeiro e segundo ano e $3.9 \mathrm{~mm}$ entre segundo e terceiro ano. Dos 161 implantes posicionados, 18 não se osseointegraram, apresentando na segunda fase cirúrgica mobilidade clínica, e radioluscidez peri-implantar determinada radiograficamente. Em 96\% dos pacientes as próteses fixas foram mantidas em função. Permaneceram adormecidos 7 implantes que, no entanto, se apresentaram osseointegrados, mas não foram incluídos no índice de sucesso. Este, para implantes individuais, foi de $87.5 \%$.

Foi apresentado no mesmo ano por LINDQUIST; CARLSSON; GLANTZ ${ }^{132}$, acompanhamento por 6 anos de pacientes totalmente desdentados 
reabilitados por meio de próteses fixas suportadas por implantes Brånemark. Foram tratados 46 pacientes, com idade entre 40 a 65 anos, dos quais 10 homens e 36 mulheres. Os seguintes critérios de sucesso foram estabelecidos: palpação e percussão do implante por instrumento obtendo-se som claro; mensuração da perda óssea através de radiografias periapicais pela técnica do paralelismo; mobilidade da prótese gerando clique audivel, após submeter-se a forças laterais repetidas na porção distal da prótese; função e estética da prótese; avaliação da oclusão obtida após reabilitação; registro do grau de desgaste separadamente para incisivos, caninos, pré-molares e molares, em escala de quatro pontos: 0-desgaste não visível, 1-desgaste único na faceta, 2desgaste marcante na faceta, 3-desgaste extremo com destruição da morfologia oclusal. Nenhuma fixação foi perdida durante o período de observação, e todas as próteses se mantiveram estáveis na última reavaliação dos critérios propostos. Em 14 pacientes registrou-se fraturas na linha média das próteses totais. Hipotetizou-se que estas se relacionavam com aumento da força mastigatória, após reabilitação por prótese tipo protocolo no arco antagonista. A complicação mais freqüente foi perda do selamento do acrílico que recobria os parafusos, sendo rapidamente retificados.

VAN STEENBERGUE et al. ${ }^{194}$, também em 1987, avaliaram clinicamente 697 implantes Brånemark, durante 5 anos. Foram reabilitados 184 pacientes com edentulismo parcial ou total, sendo 111 homens e 73 mulheres, com idade entre 24 e 81 anos. O sucesso clínico do implante foi determinado a partir dos seguintes critérios: permanecer clinicamente imóvel, quando testado entre dois instrumentos e sem estar interligado a uma prótese fixa ou a outro dente; nas radiografias periapicais pela técnica do paralelismo ausência de radioluscidez na região peri-implantar e de sinais ou sintomas de infecção. Definiu-se período cicatricial como fase compreendida entre instalação do implante e conexão do intermediário. Durante este período, removeu-se, por falta de osseointegração, $2 \%$ dos implantes posicionados na mandíbula e $8 \%$ na maxila. A fase de remodelação envolveu o período de alguns meses após a instalação da prótese, onde obtive-se $100 \%$ de sucesso nas próteses e implantes tanto na mandíbula quanto na maxila. 
Ainda no ano de 1987, WORTHINGTON; BOLENDER; TAYLOR205, relacionaram problemas e complicações encontrados durante período de 4 anos com a utilização do sistema de implantes Brånemark na Universidade de Washington. Os problemas e complicações mais comuns relacionados com instalação das fixações foram: inserção em localização proteticamente desfavorável; danos a estruturas anatômicas adjacentes como, por exemplo, ao nervo mentoniano causando parestesia; ausência de paralelismo entre fixações; deiscência durante cicatrização do tecido mole; perda óssea excessiva e ausência de osseointegração em volta da fixação. Em relação à cirurgia de conexão do intermediário foram encontrados os seguintes problemas e complicações: tamanho inadequado do intermediário; falta de adaptação do mesmo, podendo resultar em desconforto ao paciente, instabilidade do intermediário; hiperplasia gengival e formação de fïstula; fratura do intermediário; gengivite e hiperplasia gengival resultante de intermediários curtos, dificultando higienização; e fratura do parafuso do intermediário. O estágio de reconstrução protética também apresentou alguns problemas e complicações: dificuldade de fonação, fratura da prótese e do parafuso de ouro.

No ano seguinte, ALBREKTSSON et al. ${ }^{16}$, em 1988, realizaram estudo multicentro retrospectivo englobando 14 equipes suecas. Foram investigados, através de questionário, todos os 8139 implantes inseridos consecutivamente, registrando-se sucesso e falhas destes. O critério de sucesso utilizado foi proposto por ALBREKTSSON et al.15, em 1986. A partir destes pressupostos, obteve-se os seguintes resultados, respectivamente, para mandíbula e maxila: com um ano $98.88 \%$ e $84.91 \%$ de sucesso, após 3 anos 98.74\% e 86.95\% e entre 5 e 8 anos 99.1\% e 89.96\%. Em relação às mandíbulas submetidas a enxertos ou irradiadas o índice de sucesso atingiu $100 \%$, enquanto que nas maxilas submetidas a enxertos obteve-se $83.1 \%$ e nas irradiadas $81.25 \%$. Ocorreram no primeiro ano $78.8 \%$ das falhas na mandibula e somente $13.5 \%$ no segundo ano. Na maxila, $82.9 \%$ das falhas ocorreram no primeiro ano e $14.5 \%$ no segundo ano. A proporção de implantes adormecidos na mandíbula e maxila foi de, respectivamente, $0.8 \%$ e $0.3 \%$. Concluíram, a partir dos dados expostos acima, alto grau de sucesso clínico dos implantes Brånemark. 
Neste mesmo ano, ALBREKTSSON 07 coletou dados de 11 multicentros independentes em países dos seguintes continentes: Europa (4 grupos), América do Norte (5 grupos) e Austrália (2 grupos). Os resultados obtidos foram comparados com os relatados pelo grupo de Gotemburgo. As equipes possuíam experiência mínima de 3 anos e pelo menos 100 implantes consecutivamente inseridos em cada centro. Os implantes foram avaliados de acordo com critérios propostos por ALBREKTSSON et al. ${ }^{15}$, em 1986. Foram incluídos todos os implantes consecutivamente inseridos e acompanhados durante período de 1,3 e 5 anos na maxila e mandíbula. Relacionou-se o número de implantes adormecidos e os inseridos em tecido submetido à radiação ou enxerto. Com esta abordagem objetivou-se garantir inclusão de todos os sucessos ou falhas. Foram inseridos pelos 11 multicentros 3683 implantes na mandíbula em período de 0 a 8 anos e 1269 na maxila durante 0 a 6 anos. Destes, 40 implantes mandibulares e 122 maxilares submeteram-se ou à radiação ou enxerto. A percentagem de sucesso nos 11 multicentros após um, três e cinco anos foi de, respectivamente, 97.3\%, 96\% e 92.8\% para a mandíbula e 93.1\%, 89\% e 100\% para a maxila. A estabilidade das próteses mandibulares em período de 1 a 8 anos foi de $99.7 \%$, e na maxila de 1 a 6 anos 96.1\%. Permaneceram adormecidos $0.5 \%$ e $0.7 \%$ dos implantes, e estes localizavam-se, respectivamente, na mandibula e maxila. Nos implantes em áreas submetidas a enxertos na mandibula avaliados de 1 a 5 anos obteve-se sucesso de $94.7 \%$ e na maxila de $66 \%$. Em relação aos tecidos irradiados no mesmo período tanto na maxila quanto na mandíbula o sucesso foi de $100 \%$. No grupo de Gotemburgo, após avaliações de 1 obteve-se inicialmente 90.9\%, e com 3 a 5 e 10 anos 90.23\% de sucesso na mandíbula e na maxila, após 1, 3, 5 e 10 anos de acompanhamento encontrou-se, respectivamente, 92.3\%, $90.7 \%, 86.1 \%$ e $81.5 \%$. Todas as próteses se mantiveram estáveis durante os dez anos de acompanhamento. Nesses dados indicou-se que, no período avaliado, os resultados obtidos pelos estudos de multicentro foram superiores aos do centro de Gotemburgo.

Foi apresentada a experiência clínica de 11 equipes suecas, ainda no ano de 1988, por ENGQUIST et al.71. Realizou-se avaliação retrospectiva multicentro do tratamento de pacientes totalmente desdentados através de 
implantes Brånemark suportando sobre-dentaduras. Foram tratados 89 pacientes consecutivamente, com idade entre 43 a 82 anos, sendo $47 \%$ do sexo masculino e 53\% do feminino. A quantidade de tecido ósseo foi determinada clínica e radiograficamente, de acordo com a classificação proposta por LEKHOLM; ZARB ${ }^{128}$. A partir desta, dividiu-se os pacientes em 2 subgrupos: o primeiro (grupo A) com tecido ósseo em quantidade e qualidade adequados ao tratamento e o segundo (grupo B) englobando as áreas com reabsorção acentuada e/ou osso de qualidade inferior. A osseointegração foi avaliada segundo 2 critérios: imobilidade da fixação testada clinicamente e ausência radiográfica de radioluscidez peri-implantar. Inseriu-se 339 implantes, destes 32 permaneceram adormecidos. No total 67 (20\%) das fixações foram perdidas, sendo 46 (14\%) durante o período entre a primeira e a segunda cirurgia e 21 (6\%), após inserção da prótese. Entre as fixações que falharam $78 \%$ pertenciam ao grupo B. O índice de sobrevivência dos implantes foi de 98\% no grupo A, e no grupo B de $87 \%$, na maxila de $87 \%$ e na mandíbula $99 \%$. A complicação dos tecidos moles mais freqüente foi a hiperplasia, acometendo $25 \%$ dos pacientes.

No ano de 1988, LINDQUIST; CARLSSON; ROCKLER ${ }^{134}$, monitoraram perda óssea de 46 pacientes reabilitados por implantes Brånemark suportando próteses fixas mandibulares, através de radiografias periapicais pela técnica do paralelismo. O período de observação foi de no mínimo 3 anos e no máximo 6 anos. A perda óssea no primeiro ano, após a cirurgia foi de $0.5 \mathrm{~mm}$ e seqüencialmente de 0.06 a $0.08 \mathrm{~mm}$ ao ano. Nenhum implante foi removido durante o período de avaliação. A associação de higiene bucal deficiente e hábito de apertamento dos dentes influenciou significativamente a perda óssea.

Os resultados clínicos obtidos por estudo de multicentro envolvendo 24 grupos diversos em diferentes continentes foram apresentados por ALBREKTSSON; ZARB ${ }^{12}$, em 1989. Sendo que todos estes grupos possuíam, no mínimo 3 anos de experiência com implantes Brånemark, e pelo menos 100 fixações inseridas. Os dados foram coletados através de questionário enviado a cada um dos participantes. No total 13.288 implantes foram instalados, dentre os quais 225 em osso enxertado e 80 em áreas com 
exposição à radiação. O percentual de sucesso após 5 anos em mandíbulas submetidas a enxerto ósseo autógeno foi de $97.6 \%$ e, na maxila de $72.7 \%$. Já em mandíbulas expostas à radiação, o índice de sucesso foi de $100 \%$, e na maxila de $88.5 \%$, durante 5 anos de avaliação. Os demais implantes foram subdivididos em 3 grupos de acordo com o período de avaliação: de 0 a 8 anos, 1 a 8 anos e 5 a 8 anos de acompanhamento. Nestes, obteve-se respectivamente para maxila e mandíbula os seguintes percentuais de sucesso: no primeiro grupo $93.2 \%$ e $98.5 \%$, no segundo grupo $90.2 \%$ e $98.2 \%$ e no terceiro grupo $87.4 \%$ e $96.8 \%$. O índice global de sucesso na maxila foi de $85 \%$ e na mandíbula $95 \%$.

Foi relatado em 1989 por JEMT; LEKHOLM; ADELL 103, durante período de até 20 anos, índice de sucesso de 876 implantes posicionados consecutivamente em 244 pacientes parcialmente edêntulos, sendo 116 mulheres e 128 homens, com idade entre 13 a 78 anos. Os implantes foram acompanhados anualmente, por meio de avaliações clínicas e radiográficas com 1, 3 e 5 anos. Os pacientes foram divididos em três grupos, de acordo com o tempo de observação. O primeiro grupo, em período de 6 a 20 anos, apresentou-se, após dez anos, com índice de sucesso de 92\% e 79\%, respectivamente, para maxila e mandíbula. No segundo grupo, registrou-se durante um a cinco anos, 94\% de sucesso na maxila e 99\% na mandíbula. Em relação ao terceiro grupo, observou-se por um ano $100 \%$ de sucesso na mandíbula e $98,5 \%$ na maxila.

As experiências clínicas realizadas na Universidade de Tóquio foram relatadas por KOMIYAMA ${ }^{120}$, no ano de 1989, em estudo envolvendo 409 implantes fixados em 81 maxilas ou mandíbulas, sendo 61 completamente e 20 parcialmente desdentadas. Os pacientes, 36 homens e 40 mulheres com idade variando entre 18 e 81 anos. Após 5 anos de acompanhamento, o índice de sobrevivência foi de $86.5 \%$ na maxila e $98 \%$ na mandíbula. O autor observou concentração das falhas no período compreendido entre primeira e segunda fase cirúrgica. 
Desde outubro de 1983 até setembro de 1988 foram inseridas 1318 fixações Brånemark na clínica Mayo, em Rochester nos Estados Unidos. LANEY; TOLMAN ${ }^{123}$, em 1989, apresentaram os resultados obtidos em 264 pacientes desta clínica. Nestes foram posicionados 902 implantes na mandíbula, 290 na maxila, 95 em maxilas submetidas a enxertos autógenos, 45 em mandíbulas com enxertos autógenos e 20 em ossos da face. Foram removidas 11 fixações de pacientes parcial ou completamente edêntulos na mandibula, e nenhuma nos submetidos a enxertos. Na maxila, registrou-se falha de 30 fixações dos pacientes parcial ou completamente edêntulos e 14 daqueles submetidos a enxerto autógeno. Nenhuma fixação extra-oral foi removida.

VAN STEENBERGHE 193, neste mesmo ano, avaliou indice de sobrevivência de fixações Brånemark. Estas suportavam próteses parciais fixas no tratamento de edentulismo parcial em 6 centros de 3 continentes diferentes. Foram inseridas 133 fixações, sendo 40 instaladas na maxila e 93 na mandíbula. A amostra englobou 38 pacientes, dentre os quais 23 mulheres e 16 homens, com idade entre 18 a 60 anos. O tempo de observação variou de 6 a 36 meses, após instalação da prótese. A avaliação clínica incluiu mensuração da mobilidade das reconstruções, e controle das complicações neurológicas ou infecciosas. Através de radiografias pela técnica do paralelismo, observou-se não só ausência de radioluscidez em volta da fixação, como também distância entre o osso marginal e topo da fixação. As próteses estavam conectadas a dentes naturais em $58 \%$ dos casos. O índice de sucesso das fixações individuais na maxila e mandíbula foi de, respectivamente, $87 \%$ e 92\%. A maior parte das falhas, 9 das 12 fixações perdidas, ocorreram antes da reabilitação protética. A média da distância máxima entre margem óssea e junção intermediário-fixação foi de $2.5 \mathrm{~mm}$. Somente 2 das 53 próteses fixas foram perdidas durante o período de observação. Concluiu-se, que próteses suportadas por implantes osseointegrados também podem ser utilizadas com sucesso na reabilitação do edentulismo parcial.

No ano seguinte, ADELL et al.04, avaliaram 4636 implantes posicionados pelo grupo de Gotemburgo. Estes foram inseridos em 759 
mandibulas ou maxilas totalmente edêntulas de 700 pacientes, sendo $56.8 \%$ mulheres e $43.2 \%$ homens, com idade entre 19 a 79 anos. Os implantes foram acompanhados por no máximo 24 anos. Em relação aos índices de sobrevivência dos implantes, na maxila aos 5 anos foi de $84 \%$, $89 \%$ e $92 \%$, aos 10 anos $81 \%$ e $82 \%$, e aos 16 anos $78 \%$. Na mandíbula foi de $91 \%, 98 \%$ e $99 \%$ aos 5 anos, $89 \%$ e $98 \%$ aos 10 anos, e $86 \%$ aos 16 anos. As diferentes percentagens aos 5 e 10 anos referem-se aos resultados para subdivisão em diferentes "Grupos de rotina" dos implantes nos intervalos de 5 a 10, 10 a 16, e 1 a 5 anos de observação, respectivamente. Na maxila, mais de $95 \%$ das próteses se mantiveram estáveis em 5 e 10 anos e, pelo menos, 92\% com 16 anos. Na mandíbula, obteve-se $99 \%$ em todos intervalos de tempo. A partir dos dados apresentados demonstrou-se alta efetividade do sistema Brånemark, conforme deduzidos pelos resultados longitudinais apresentados acima em população apreciável.

Foram acessados por AHLQVIST et al.05, no mesmo ano, índice de sobrevivência dos implantes e de estabilidade das próteses suportadas por estes, além da perda óssea marginal ao redor dos implantes. Os pacientes foram tratados com implantes Brånemark na Universidade de Ümea. No período de 1981 a 1985, inseriu-se 269 implantes em 48 pacientes totalmente desdentados, sendo 17 maxilas e 33 mandíbulas. Após conexão da prótese, acompanhou-se durante 2 anos com exames clínicos e radiográficos anuais.

Os seguintes critérios foram utilizados, a fim de avaliar a sobrevivência dos implantes:

1-O implante deveria se manter em função suportando prótese clinicamente estável. Este parâmetro foi registrado sem remoções periódicas das reconstruções protéticas;

2-Ausência de dor no local das fixações;

3-O tecido mole ao redor dos implantes deveria se apresentar clinicamente saudável ou com apenas pequeno grau de inflamação;

4-Radiograficamente, não deveria demonstrar radioluscidez periimplantar ou outras condições patológicas adjacentes aos implantes.

Após 2 anos de controle, o índice de sobrevivência dos implantes foi de $89 \%$ na maxila e $97 \%$ na mandíbula. A estabilidade das próteses na 
maxila foi de 94\% e de 97\% na mandibula. Registrou-se, em dois anos, perda óssea média de $1.1 \mathrm{~mm}$ na mandíbula e $1.7 \mathrm{~mm}$ na maxila. A maior parte da perda óssea ocorreu durante o primeiro ano. Esta apresentou-se mais acentuada em áreas com reabsorção pré-operatória mínima do rebordo alveolar, do que em áreas com presença de reabsorções moderadas a avançadas. Os implantes mandibulares posicionados próximos à linha média apresentaram-se com perda óssea mais acentuada, do que os localizados em posição mais posterior.

Foi apresentado por GREGORY et al.81, em 1990, estudo clínico utilizando sistema de implantes Brånemark. Foram tratados treze pacientes totalmente edêntulos, sendo 4 do sexo masculino e 9 do feminino, com idade entre 41 e 68 anos. Os efeitos clínicos e psicológicos do tratamento foram registrados a cada 6 meses durante 3 anos. Coletou-se estes dados por meio de exame clínico, questionário específico para avaliação da personalidade antes e após tratamento e de outro relacionado às reações subjetivas dos pacientes ao tratamento. O exame clínico consistiu da observação dos seguintes parâmetros determinantes da osseointegração dos implantes: imobilidade da fixação, som característico à percussão, ausência de dor e de radioluscidez peri-implantar, registro das complicações durante o tratamento incluindo perda ou fratura da infra-estrutura, avaliação radiográfica da altura do osso marginal e qualidade óssea peri-implantar. Não ocorreu osseointegração em 6\% dos implantes e estes foram removidos durante segundo ato cirúrgico. Em relação às próteses, $50 \%$ se desajustaram, entretanto permaneceram estáveis após reajustes. Os pacientes relataram no questionário segurança acentuada pós-tratamento, resultando em relações pessoais e sociais melhoradas.

Foram acompanhadas por JEMT; LEKHOLM; GRÖNDAHL ${ }^{104}$, em 1990, reconstruções protéticas unitárias suportadas por implantes Brånemark, durante 3 anos. Para este fim, utilizou-se amostra de 16 pacientes, sendo 8 homens e 8 mulheres, com idade variável entre 16 e 48 anos. Tratou-se 16 casos de maxila e um de mandíbula, totalizando 23 fixações posicionadas. Após três anos em função, os implantes foram examinados quanto a: presença ou ausência de placa, recessão gengival e gengivite em 4 faces, e amostra para 
exame microbiológico em 8 pacientes. Registraram também nível ósseo marginal, por meio de radiografias periapicais pela técnica do paralelismo, após a instalação da prótese, no primeiro e terceiro ano. Permaneceram em função 21 implantes (91\%) suportando coroas unitárias. Em 8 (35\%) reconstruções as coroas permaneceram estáveis, sem perda do parafuso de ouro ou reposição da prótese. Registrou-se acúmulo de placa bacteriana em $12 \%$ das superfícies e em 19\% dos implantes detectou-se sinal de gengivite. Em 3 casos detectou-se recessões gengivais maiores do que $1 \mathrm{~mm}$. A microbiota peri-implantar apresentou-se similar a dos dentes adjacentes. Em relação ao osso marginal, este reduziu-se em aproximadamente $1 \mathrm{~mm}$ durante o primeiro ano, e posteriormente diminuindo padrão de perda.

No mesmo ano, VAN STEENBERGHE et al. ${ }^{195}$, relataram em estudo retrospectivo, os dados obtidos em 9 centros clinicos utilizando sistema Brånemark. Foram tratados 169 pacientes parcialmente edêntulos com idade entre 18 e 70 anos. Estes foram avaliados durante o tratamento, após 1 semana, 1, 6 e 12 meses e, depois da instalação da prótese, com 24, 36, 48 e 60 meses. Os seguintes parâmetros clínicos foram avaliados: indice de placa, gengivite, profundidade de sondagem, indice de sangramento, mobilidade dentária e função estomatognática em 558 implantes inseridos. Entretanto, destes, somente 521 em 164 pacientes permaneceram acompanhados até a conclusão da fase protética. Os implantes foram perdidos ou não incluídos por diversos motivos: ausência de osseointegração (19), abandono do estudo pelo paciente (11), motivos protéticos (6) e falha durante confecção da prótese (1). Foram instaladas 199 próteses suportadas por, no mínimo, 2 implantes sem envolver as unidade dentárias adjacentes. Durante o período de observação, houve redução inicial do índice de placa, sangramento e inflamação gengival. Posteriormente, estes se mantiveram estáveis. As falhas incidiram mais em áreas de qualidade óssea desfavorável, no sexo masculino e em implantes de menor comprimento. Os resultados sugeriram índice de sucesso igual ou, até mesmo superior aos obtidos em avaliações de pacientes totalmente edêntulos. 
Ainda no ano de 1990, ZARB; SCHMITT207, realizaram estudo prospectivo iniciado em 1979 na Universidade de Toronto. Neste acompanhouse 46 pacientes totalmente edêntulos, sendo 36 mulheres e 10 homens, com idade entre 28 e 71 anos. Foram inseridos 274 implantes em 49 arcadas, dentre as quais 43 mandíbulas e 6 maxilas, avaliadas de acordo com os seguintes critérios: imobilidade dos implantes individualmente, após a remoção da prótese; ausência de evidência radiográfica de radioluscidez peri-implantar; perda óssea vertical mínima ao redor dos implantes, demonstrada por radiografias periapicais pela técnica do paralelismo; ausência de complicações persistentes nos tecidos moles peri-implantares determinadas pelos índices periodontais. Entre 4 e 9 anos de acompanhamento pós-inserção dos implantes, 244 ou 89.05\% destes permaneceram osseointegrados. Em 30 falhas registradas, 21 foram detectadas no segundo estágio cirúrgico com presença de mobilidade da fixação. O tratamento protético obteve $100 \%$ de sucesso nas 45 próteses fixas e 5 sobre-dentaduras.

Neste mesmo ano, em continuação do trabalho anterior dos mesmos autores ${ }^{208}$, utilizando a mesma amostra de pacientes, descreveu-se problemas clínicos e complicações encontrados durante o tratamento, desde primeiro estágio cirúrgico até os da fase de manutenção. Durante a primeira fase cirúrgica, relatou-se posicionamento ou alinhamento do implante em local proteticamente desfavorável. No período pós-operatório, registrou-se edema, equimose e deiscência dos tecidos moles. No segundo estágio cirúrgico, 21 implantes não se osseointegraram, 6 permaneceram adormecidos e 6 tiveram problemas com a conexão do intermediário. Após o tratamento protético, relatou-se poucas complicações relacionadas com os tecidos moles, algumas estruturais e outras funcionais. O problema estrutural mais freqüente foi fratura do parafuso de ouro (53 casos), seguido da fratura da estrutura de prata-paládio (13 casos) e do intermediário (9 casos). As complicações funcionais mais freqüentes foram desconforto muscular transitório e/ou desordens da ATM (12 casos). 
No ano seguinte foi apresentado por ÄSTRAND et al.25 estudo longitudinal de 2 anos. Neste avaliou-se combinação de dentes naturais com implantes osseointegrados Brånemark na reabilitação de pacientes parcialmente desdentados. Em 23 pacientes classe I de Kennedy na mandíbula confeccionou-se, em uma hemi-arcada, próteses suportadas por 2 implantes (prótese tipo I) e, no outro lado, próteses suportadas por um implante e um dente natural (prótese tipo II). Foram inseridos 69 implantes, e sobre estes, instalou-se 46 próteses. Os pacientes foram examinados após a conexão das próteses e depois de 6 meses, 1 e 2 anos. Os seguintes critérios foram avaliados:

1- Sobrevivência do implante, definida de acordo com:

a- funcionalidade do implante como suporte para prótese fixa clinicamente estável;

b- Ausência de dor proveniente do implante;

c- Os tecidos moles em volta do intermediário deveriam se apresentar clinicamente sadios ou com grau de inflamação mínimo;

d- Radiograficamente, não deveria demonstrar radioluscidez periimplantar ou qualquer outra condição patológica adjacente ao implante.

2- Estabilidade protética, registrada através da ausência de mobilidade clinicamente detectada nas próteses.

3- Distúrbios sensoriais no lábio ou queixo, e a qualidade destes foi classificada em três grupos: ausência de distúrbios, hipestesia e anestesia. A extensão do distúrbio foi dividida em dois grupos: toda a área estimulada pelo nervo mentoniano ou apenas parte desta.

Durante o período de observação, oito fixações foram perdidas, e 61 (88.4\%) implantes classificados como sobreviventes. Obteve-se os seguintes indices de falha dos implantes nos dois tipos de prótese: 5 fixações pertenciam às próteses tipo I (10.9\%), e 2 às do tipo II (8.7\%), e uma fixação foi perdida antes de se submeter às cargas oclusais. A estabilidade das próteses, após 2 anos, foi de $87 \%$ e 40 das 46 próteses se mantiveram em posição. Depois de 2 anos, distúrbios sensoriais se apresentaram em 9 sítios (19\%), contudo extensão e grau de distúrbio foram reduzidas no decorrer dos três anos. Os resultados deste estudo não indicaram desvantagens na conexão de dentes e implantes na mesma reconstrução protética. 
Neste mesmo ano, FRIBERG; JEMT; LEKHOLM75, acompanharam retrospectivamente 4641 fixações Brånemark, desde primeira fase da cirurgia até finalização da confecção da prótese. Os implantes foram posicionados durante periodo de 3 anos em 943 mandíbulas ou maxilas, representativas de 889 pacientes parcial ou totalmente edêntulos. Nestes, houve predomínio de mandíbulas (564/943) e de mulheres. A média de idade foi de 57.5 anos, variando de 13 a 88 anos no momento da colocação das fixações. Somente 69 $(1.5 \%)$ dos implantes não se osseointegraram, sendo que maior parte das perdas ocorreram em maxilas completamente desdentadas (46/69), nas quais o osso apresentou pouca qualidade e reabsorção severa. Além disso, as falhas predominaram em fixações menores $(7 \mathrm{~mm})$ inseridas em pacientes completamente edêntulos. A maior parte dos implantes móveis foi registrado durante a cirurgia para conexão do intermediário $(48 / 69)$.

Em estudo retrospectivo, também em 1991, TRIPLETT et al. ${ }^{192}$, avaliaram índice de sucesso de implantes Brånemark inseridos em mandíbulas atróficas totalmente desdentadas. Foram tratados 28 pacientes, sendo 21 mulheres e 7 homens, com idade variável entre 30 e 78 anos e acompanhados durante 15 a 62 meses. A mandibula deveria apresenta-se com altura óssea anterior de no máximo $10 \mathrm{~mm}$, mensurada através de radiografias cefalométricas laterais. Somente implantes localizados anteriormente ao forame mentoniano, e em função por pelo menos um ano foram incluídos no estudo. Foram posicionados 130 implantes, sendo 46 de $7 \mathrm{~mm}$ e 84 de $10 \mathrm{~mm}$. Utilizando-se o critério de sucesso proposto por SMITH; ZARB ${ }^{186}$, em 1989 . No total seis implantes de $10 \mathrm{~mm}$, e dois de $7 \mathrm{~mm}$ falharam. O índice de sucesso para os implantes de 7 e $10 \mathrm{~mm}$ foi de, respectivamente, 96\% e 93\% e o total foi de $94 \%$. O índice de sucesso das próteses fixas foi de $89 \%$ e das sobredentaduras de $95 \%$.

Ainda neste mesmo ano, JAFFIN; BERMAN ${ }^{100}$, analisaram a falha de implantes, durante 5 anos, em amostra constituída de 1054 fixações consecutivamente instaladas. Destas, 444 se localizavam na maxila e 610 na mandibula. Correlacionaram os niveis de falha e sucesso com existência de osso tipo IV. Foram posicionadas em osso tipo I, II e III 952 (90\%) das fixações 
e somente 3\% destas foram perdidas. Entretanto, em 102 (10\%) fixações posicionadas no osso tipo IV, 35\% falharam. A partir desses dados, os autores sugeriram determinação pré-cirúrgica das áreas de osso tipo IV, com finalidade de reduzir a percentagem de falhas.

Foi apresentado, em 1991, por JEMT101, estudo retrospectivo sobre acompanhamento de 391 mandíbulas e maxilas completamente desdentadas tratadas consecutivamente por próteses fixas suportadas por 2199 implantes Brånemark. Estas foram avaliadas desde o posicionamento até primeira reavaliação anual, após terem sido inseridas em 384 pacientes. Durante o primeiro ano, 11 pacientes abandonaram o estudo e 380 (97.2\%) das próteses foram acompanhadas. Entre posicionamento do implante e antes da conexão das próteses ocorreram $1.1 \%$ de falhas, sendo que houveram mais falhas na maxila do que na mandibula. O índice geral de sucesso foi de $99.5 \%$ e 98.1\%, respectivamente para as próteses e implantes no período de um ano.

Neste mesmo ano, JEMT e colaboradores ${ }^{106}$, avaliaram 117 implantes Brånemark posicionados em sete multicentros clínicos, suportando restaurações unitárias em 92 pacientes, com idade entre 14 e 70 anos, sendo $49 \%$ do sexo feminino e $51 \%$ do masculino. A funcionalidade clínica foi examinada com visitas após 1 semana, e com 1,6, 12, 24, 36, 48 e 60meses, e neste período somente 3 implantes $(2.8 \%)$ foram perdidos. Os seguintes parâmetros clínicos foram registrados: gengivite, profundidade de sondagem, índice de sangramento e mobilidade dentária. A condição gengival se apresentou saudável em volta das coroas unitárias, coincidindo com a situação clínica dos dentes naturais adjacentes. Foram realizados reajustes em $26 \%$ dos parafusos de retenção das coroas durante período inicial de observação. Entretanto, a freqüência destes se reduziu com a progressão do estudo.

No mesmo ano, KARLSSON; JEMT ${ }^{114}$, relataram possiveis adaptações que alteraram o padrão rítmico da mastigação, após inserção de prótese fixa mandibular suportada por implantes osseointegrados. A amostra compreendia 16 pacientes completamente desdentados. Destes, haviam 11 mulheres e 5 homens, com idade média de 50 anos. Registrou-se duração do 
ciclo mastigatório, velocidade e posicionamento mandibular antes, 2 e 10 anos após reabilitação, mas não puderam detectar alterações discrepantes. Observaram, entretanto, aumento na velocidade do ciclo mastigatório e alteração do posicionamento mandibular 2 meses após reabilitação. Esta tendência se estabilizou a longo prazo, ou seja, na reavaliação depois de 10 anos.

PAREL; TJELLSTRÖM 162, no mesmo ano, relataram experiência com próteses faciais suportadas por implantes osseointegrados. Estas foram realizadas em 13 centros nos Estados Unidos e um na Suécia. Os resultados destes dois países foram apresentados dissociados e subdividido em dois grupos: pacientes submetidos à radioterapia e o controle sem incidência de radiação. A exposição à radiação poderia modificar vascularização do sítio receptor diminuindo-a, e comprometendo o potencial de osseointegração. Os pacientes tratados haviam recebido entre 4.000 e 6.000 rads e nenhum destes foi submetido subseqüentemente à terapia por oxigênio hiperbárico. Nos Estados Unidos inseriu-se 268 implantes em 84 indivíduos não irradiados alcançando índice de sucesso total de 94.4\%. Em 11 pacientes tratados por radioterapia posicionou-se 51 implantes com índice de sucesso total de 64.7\%. No grupo sueco, num total de 767 implantes colocados em 130 pacientes não irradiados, obteve-se indice de sucesso global de 98.4\%. Os 16 pacientes irradiados com 57 implantes inseridos alcançaram índice de sucesso de 57.9\%. Nas duas amostras avaliadas, em relação à posição, a órbita foi a região com maior indice de falhas.

QUIRYNEN et al. ${ }^{167}$, em 1991, observaram reações dos tecidos periimplantares, mensuradas através de métodos clínicos e radiográficos, em torno de 196 implantes Brånemark, pilares de sobre-dentaduras. Foram acompanhados, durante um período de 4 anos, 86 pacientes (65 mulheres e 21 homens) consecutivos. As sobre-dentaduras foram inseridas em 6 maxilas e 80 mandibulas, nas quais posicionou-se somente dois implantes. Considerou-se os critérios de sucesso de ALBREKTSSON et al. ${ }^{15}$. Os seguintes parâmetros clínicos foram registrados nos implantes: presença de placa bacteriana aderida aos intermediários, sangramento à sondagem, profundidade de sondagem, 
distância entre topo do intermediário e margem da gengiva, nível de inserção e mobilidade entre dois instrumentos e com o Perioteste. A altura do osso marginal em volta das fixações foi avaliada radiograficamente, utilizando-se técnica do paralelismo. Somente 2 das 196 fixações foram perdidas, ambas durante cirurgia para conexão do intermediário e se localizavam na mandíbula. Na maxila nenhum implante falhou. O número de superfícies com placa (40\%) e com inflamação gengival (55\%) se manteve quase constante em toda a avaliação. A profundidade de sondagem variou de 2.7 a $3.2 \mathrm{~mm}$. A distância da margem gengival ao topo do intermediário aumentou consideravelmente de 1.8 a $2.9 \mathrm{~mm}$. O Perioteste variou de $-3 \mathrm{a}+1.5$. Durante o primeiro ano a perda óssea radiográfica foi de $0.8 \mathrm{~mm}$, e nos anos subseqüentes apresentou-se inferior a $0.1 \mathrm{~mm}$. Não se estabeleceu correlações entre as alterações na altura do osso marginal e os diversos parâmetros clínicos avaliados.

No mesmo ano, SMEDBERG e colaboradores 185, trataram 22 pacientes, 8 homens e 14 mulheres, nos quais inseriu-se 86 fixações, para suportar sobre-dentaduras encaixadas através de clipes sobre barras esplintando os implantes. De acordo com os autores, esta consistiu em alternativa de reabilitação viável, especialmente na maxila, quando a prótese fixa suportada por implantes não satisfizesse a estética e fonética, dificultasse a higiene bucal e proporcionasse desconforto ao paciente. Após o ajuste final da prótese os pacientes relataram a sua opinião subjetiva sobre o conforto, fonética e estética da reabilitação através de uma escala analógica de 0 a 10 . Os pacientes relacionaram escore médio de 9, 7.6 e 8.1, respectivamente para a estética, fonética e conforto da prótese. Conclui-se que, a avaliação da prótese indicou sucesso inicial do tratamento proposto.

TOLMAN; KELLER ${ }^{190}$, também em 1991, inseriram em 61 pacientes, 303 implantes em 54 mandíbulas e 7 maxilas, imediatamente após extração e alveoloplastia. O período de observação variou de 1 a 6 anos. Somente dois implantes foram perdidos na mandibula e nenhum na maxila. Permaneceram adormecidos dois implantes mandibulares e três maxilares, entretanto estes mantiveram a osseointegração e não foram considerados como 
falha. Ao final da avaliação, 296 implantes se mantiveram em função suportando as reconstruções protéticas.

No mesmo ano, DRAGO68, avaliou os níveis de osseointegração obtidos em 169 pacientes parcialmente desdentados, nos quais se inseriu consecutivamente 673 fixações Brånemark, correlacionando-as com a localização anatômica dos mesmos. A osseointegração ocorreu em $89.1 \%$ dos implantes posicionados na porção anterior da maxila, $71.4 \%$ na porção posterior da maxila, $96.7 \%$ na porção anterior da mandíbula, e 98.7\% na porção posterior da mandíbula. Sugeriram a apresentação de dados dissociados para avaliação da osseointegração, relacionando-os com a localização anatômica dos implantes, evitando-se as percentagens globais dos resultados obtidos.

No ano de 1992, ELLIES70, determinou a prevalência de complicações relacionadas com alterações na sensibilidade depois da inserção de implantes na mandíbula. Aplicou-se questionário retrospectivo em 266 pacientes tratados com implantes osseointegrados e destes $80 \%$ responderam. Em 37\% dos pacientes registrou-se alterações na sensibilidade e a longo prazo manteve-se em 13\% destes. Em 60\% dos pacientes a alteração se iniciou depois da primeira cirurgia e em 17\% depois do segundo ato cirúrgico. Em 80\% dos casos a alteração sensorial se resolveu em 6 meses. Os pacientes que permaneceram com distúrbios na sensibilidade relataram que as vantagens da cirurgia superaram as desvantagens da complicação sensorial. A prevalência em mulheres foi mais acentuada do que nos homens, como também nos indivíduos com diabetes.

FRIBERG; GRÖNDAHL; LEKHOLM74, em 1992, avaliaram o implante Brånemark auto-rosqueável (Mk-II), comparando com os implantes convencionais. O implante auto-rosqueável foi projetado para inserção em tecidos ósseos menos densos. Os dois tipos de implantes foram analisados em relação à técnica de inserção, remodelação do osso marginal e percentual de sobrevivência. Participaram deste estudo 30 pacientes, sendo 17 homens e 13 mulheres, com idade entre 34 a 82 anos, representando 21 mandíbulas e 9 
maxilas. Em cada um dos pacientes, posicionou-se implantes convencionais (91) e auto-rosqueáveis (88), com total de 179 implantes, acompanhando-os por, no mínimo, 2 e, no máximo, 3 anos. Foram realizadas tomadas radiográficas periapicais pela técnica do paralelismo, inicialmente, na conexão do intermediário e da prótese e depois a cada ano. Nestas, a distância entre um ponto de referência no implante e o tecido ósseo foi medida. Em treze dos 62 (21\%) implantes mandibulares auto-rosqueáveis ocorreram problemas durante a colocação só alcançando a posição adequada após se utilizar o macho de tarraxa para inserção manual. Este problema não ocorreu com a utilização dos implantes convencionais. Na maxila, nenhum dos dois tipos de implantes apresentou problemas. Uma fixação convencional e outra auto-rosqueável não se osseointegraram. Observou-se radioluscidez no osso da porção apical de 2 implantes, sendo um de cada tipo. A média de reabsorção óssea marginal, após um ano de acompanhamento, variou de 0.5 a $0.6 \mathrm{~mm}$ para os dois tipos de fixação.

Foram relatadas falhas e complicações em 127 próteses parciais fixas consecutivas ancoradas em 354 implantes Brånemark por JEMT; LINDÉN; LEKHOLM ${ }^{105}$, em 1992. Os implantes foram acompanhados desde a conclusão do tratamento protético até a primeira reavaliação depois de um ano. A amostra englobou 87 pacientes, destes 45 do sexo masculino e 42 do feminino, com idade entre 16 a 77 anos. Durante o período de acompanhamento, o índice de sucesso dos implantes foi de 98.6\% e nenhuma das próteses foi perdida. A complicação mais freqüente no primeiro ano foi relacionada à perda dos parafusos de ouro em 49\% das maxilas e $20.8 \%$ das mandíbulas tratadas, e em menor freqüência reclamações relacionadas à estética.

Foram reportadas por JEMT et al. ${ }^{107}$, no ano de 1992, falhas e complicações em 92 sobre-dentaduras suportadas por implantes consecutivamente inseridas em maxilas severamente reabsorvidas. Estas foram acompanhadas desde a conclusão da prótese até a primeira reavaliação com um ano. O grupo teste compreendia 92 pacientes, 63 mulheres e 29 homens, com idade entre 33 e 80 anos. As 92 sobre-dentaduras foram suportadas por 
430 implantes. Destes, 69 (16\%) foram perdidos e removidos durante o período de acompanhamento. Os implantes móveis causaram 7 falhas completas do tratamento por sobre-dentaduras. Os problemas mais freqüentes durante a avaliação se relacionaram à hiperplasia ou inflamação da mucosa periimplantar em $20.9 \%$ dos pacientes e fraturas por fadiga da resina acrílica e dos clipes retentivos. A manutenção após inserção da prótese foi mais constante para as sobre-dentaduras, do que nas próteses fixas. Entretanto, um menor número de problemas relacionados à fonação foi relatado em casos de sobredentaduras, do que nos de prótese fixa.

Em estudo longitudinal, KIYAK e colaboradores ${ }^{118}$, no ano de 1992 , avaliaram através de questionário o impacto psicológico do tratamento de 27 pacientes reabilitados através de implantes osseointegrados. Os pacientes responderam seis questionários desde o periodo anterior à primeira cirurgia até a primeira revisão depois da instalação da prótese. Nestes questionários abordou-se os seguintes itens: problemas relativos à fisiologia bucal e psicológicos, expectativas e dificuldades durante e após às cirurgias, satisfação com a cirurgia e com a nova imagem, neurotismo e auto-estima. O problema mais comum antes da cirurgia consistiu na dificuldade de mastigação e não na estética. Os problemas inicialmente relatados melhoraram significativamente depois da segunda cirurgia. As expectativas relacionadas com o pós-operatório da primeira cirurgia corresponderam com às aguardadas pelo paciente. Entretanto, na segunda cirurgia as expectativas foram mais negativas do que a realidade. Os pacientes relataram melhoras significativas não somente nos dentes, como também no aspecto da face, boca e corpo em geral. Os escores sobre a satisfação com o tratamento apresentaram-se geralmente altos e continuaram a melhorar até o último questionário. $O$ único grupo com resultados negativos consistiu-se nos pacientes com neurotismo detectado anteriormente ao tratamento.

JOHNS et al. ${ }^{109}$, em 1992, apresentaram avaliação, durante um ano, realizada em 9 centros clínicos de sobre-dentaduras suportadas por implantes Brånemark na maxila e mandíbula. Inicialmente, 133 pacientes estavam participando do estudo, $59 \%$ de mulheres e $41 \%$ de homens, com 
idade entre 32 a 75 anos. Foram inseridos 117 e 393 fixações em, respectivamente, 30 maxilas e 393 mandibulas, observados durante um ano. Durante este período, os seguintes parâmetros clínicos foram registrados: índice de placa bacteriana, gengivite, altura do topo do intermediário em relação à mucosa, complicações pós-operatórias e na mucosa, testes funcionais, radiografias na época do posicionamento da prótese e após um ano em função. Ao final do estudo, estavam presentes 127 pacientes reabilitados por sobre-dentaduras, 29 na maxila e 98 na mandíbula, suportadas por 279 implantes estáveis. O índice de sucesso acumulado foi de $81.2 \%$ e 96.2\%, respectivamente na maxila e mandíbula. Em relação ao comprimento, a maior parte dos implantes perdidos era de $7 \mathrm{~mm}$. As complicações cirúrgicas se resolveram durante o acompanhamento, e somente um paciente permaneceu com parestesia, após um ano. A manutenção das sobre-dentaduras envolveu fraturas das próteses ou clipes, reativação destes e necessidade de reembasamentos. Durante o primeiro ano de manutenção a complicação protética mais freqüente se relacionou com reativação do clipe e em alguns casos mais de uma vez, em seguida fratura do clipe e reembasamento da prótese. Não se estabeleceu alterações na distância entre topo do intermediário e tecido gengival. A perda óssea marginal média durante 1 ano foi mesialmente de $0.4 \mathrm{~mm}$ e $0.3 \mathrm{~mm}$, e distalmente de $0.6 \mathrm{~mm}$ e $0.2 \mathrm{~mm}$, respectivamente para maxila e mandibula. 
Ainda em 1992, NAERT et al. ${ }^{152}$, avaliaram durante período máximo de 6 anos, 509 implantes Brånemark. Estes foram inseridos consecutivamente em 146 pacientes parcialmente desdentados, nos quais planejou-se a conexão de 217 próteses parciais fixas. Destas, concretizaram-se 201 suportadas por 472 implantes. Os 146 pacientes compreendiam 94 mulheres e 52 homens, com idade entre 21 a 83 anos. Foram inseridos 304 implantes em 97 maxilas e 205 em 71 mandíbulas. Utilizou-se os critérios de ALBREKTSSON et al.15, para determinar o sucesso da osseointegração. O índice de falha acumulado, após conexão do intermediário, foi de 3.9\% e 4.1\% respectivamente para maxila e mandíbula. A ausência de estabilidade da prótese foi de $4.1 \%$ na maxila e $5.4 \%$ na mandíbula. A média da perda óssea marginal anual foi de $0.77 \mathrm{~mm}$ na maxila e $0.96 \mathrm{~mm}$ na mandíbula durante o primeiro ano, e em média $0.1 \mathrm{~mm}$ nos anos subseqüentes. A forma de conexão entre os dentes e os implantes, e o uso da porcelana ou resina composta na oclusal não influenciaram na altura do osso marginal em volta dos implantes. Concluíram, assim, que os resultados atestam a efetividade na utilização do sistema de implantes Brånemark no tratamento do edentulismo parcial.

QUIRYNEN et al. ${ }^{169}$, no mesmo ano, apresentou os aspectos periodontais da amostra avaliada no estudo de NAERT ${ }^{152}$, apresentado no parágrafo anterior. Investigou-se as fixações Brånemark suportando próteses fixas em estudo retrospectivo de 6 anos e observou-se as reações teciduais em volta de 509 implantes. Foram inseridas 304 fixações em 97 maxilas e 205 fixações em 71 mandibulas de 147 pacientes consecutivos. As 94 mulheres e 52 homens foram reabilitados através de próteses parciais fixas, suportadas unicamente por implantes (60\%) ou combinando-se dentes e implantes (40\%). Avaliaram o índice de: sangramento à sondagem e a mobilidade testada entre dois instrumentos e através do Perioteste. Detectaram ausência de sangramento à sondagem em $75 \%$ das fixações na mandíbula e o índice permaneceu constante em todo o estudo. Na maxila, o percentual reduziu de $70.2 \%$ no primeiro para 55.6\% no terceiro ano. A perda óssea, registrada por radiografias periapicais pela técnica do paralelismo, foi de $0.9 \mathrm{~mm}$ durante o primeiro ano, e nos anos subseqüentes, inferior a $0.1 \mathrm{~mm}$. Em $70 \%$ das 
fixações detectou-se Perioteste de -1 ou menos. Os critérios de sucesso empregados foram os de ALBREKTSSON et al.15. Foram perdidos 23 implantes antes de se submeter às cargas oclusais, sendo 16 na maxila e 8 na mandíbula. Após a conexão da prótese e da atuação das forças oclusais, durante período que variou de 2 a 77 meses, 6 implantes apresentaram sinais de falta de osseointegração. O índice acumulado de falha para as fixações individuais após 6 anos foi de $6.5 \%$ na mandíbula e 5.7\% na maxila.

No ano de 1992, TOLMAN e LANEY191, durante período de no máximo 78 meses acompanharam 353 pacientes reabilitados proteticamente por 1778 implantes Brånemark. O total de maxilas e mandíbulas tratadas foi de 407, sendo 303 totalmente e 104 parcialmente edêntulas. Registrou-se a falha de 19 e 2 adormecidos em 1250 implantes localizados na mandíbula e na maxila 47 em 528 implantes inseridos. Deve-se ressaltar que 35 implantes da maxila foram perdidos em apenas 8 pacientes. Em 152 pacientes não se registrou nenhuma complicação, em 37 apenas uma vez e 160 foram atendidos algumas vezes. Entretanto, neste último grupo 4 pacientes retornaram a utilizar prótese total na maxila. Registrou-se como complicação mais freqüente a inflamação dos tecidos moles peri-implantares. A hiperplasia foi detectada em 102 ocasiões em 58 pacientes e em 39 lesões necessitou-se da excisão cirúrgica do tecido. As complicações dos tecidos moles foram tratadas inicialmente de maneira conservadora e procedeu-se o incentivo à higiene bucal. A deficiência desta apresentou-se em 104 ocasiões em 47 pacientes e a presença desta alteração se caracterizou por recorrência no mesmo indivíduo. A fratura do parafuso da prótese e do intermediário foi presente com maior freqüência nos pacientes totalmente edêntulos na mandíbula, 89 ocorrências em 77 mandibulas, e 77\% destas ocorreram entre o segundo e quarto ano de utilização da prótese. Três pacientes fraturaram o implante suportando próteses tipo protocolo. A maxila foi predominantemente restaurada por sobredentaduras apresentando-se com problemas relativos aos clipes e reembasamento desta. Em 5 das 289 mandíbulas reabilitadas relatou-se alteração na sensibilidade do lábio inferior devido ao nervo mentoniano, mas após 16 meses resolveu-se em 4 pacientes e continuou em 1 . 
PYLANT et al. ${ }^{166}$, em 1992, relataram o tratamento de 34 pacientes parcialmente edêntulos, com idade entre 19 e 76 anos. Estes foram consecutivamente submetidos à inserção de 102 implantes, sendo 28 na maxila e 74 na mandíbula. Os implantes foram acompanhados durante período variável de 6 a 49 meses, após a conexão da prótese. Utilizou-se os critérios de SMITH; ZARB ${ }^{186}$ do ano de 1989, para avaliar o sucesso dos implantes e das próteses. Durante a segunda fase cirúrgica foram detectadas 7 das 12 falhas. O índice de sucesso global foi de $88.2 \%$, sendo $87.8 \%$ na mandíbula e $89.3 \%$ na maxila. Foram acompanhadas 41 próteses, sendo 28 (68\%) de extremo livre e o restante conectada aos dentes naturais. A média de perda óssea marginal foi determinada através de radiografias periapicais pela técnica do paralelismo, e esta por fixação foi de $1.9 \mathrm{~mm}$, variando de 0.5 a $5 \mathrm{~mm}$.

No ano seguinte, BAHAT ${ }^{30}$, investigou o índice de sucesso obtido no posicionamento de 732 implantes Brånemark consecutivos inseridos na maxila e acompanhados durante período de 5 a 70 meses. Foram colocadas de 1 a 9 fixações na região pré-citada de 213 pacientes parcialmente edêntulos. A reconstrução foi realizada através de próteses parciais fixas de porcelana e acompanhadas após a incidência das cargas oclusais. Para um implante ser considerado como sucesso deveria apresentar as seguintes características: ausência de radioluscidez peri-implantar e imobilidade em manipulação bimanual. Em 29 pacientes, falharam 34 implantes, dos quais 8 foram substituídos e apenas um destes falhou. O índice total de falhas foi de $4.8 \%$, ou seja, 35 fixações do total de 732. O tecido ósseo foi classificado de acordo com os critérios de LEKHOLM; ZARB ${ }^{128}$. O percentual de falhas em osso tipo IV foi de $5.5 \%$, apresentando-se ligeiramente maior do que nos ossos tipo II e III (4.6\%). Em relação à área de molar, o índice foi de 5.3\%, e de pré-molar de $4.5 \%$. Considerando-se o comprimento dos implantes, os de $7 \mathrm{~mm}$ apresentaram índice de falhas de $9.5 \%$ e os demais de $3.8 \%$. 
No ano de 1994, CUNE; PUTTER; HOOGSTRATEN 57 , conduziram estudo com finalidade de avaliar clinicamente a reabilitação de pacientes através de sobre-dentaduras. Foram investigados por dois examinadores 429 pacientes com 1177 implantes inseridos. Registrou-se, principalmente no primeiro ano depois da instalação da prótese, a falha de 59 implantes, sendo 30 na maxila e 29 na mandíbula e em 11 pacientes a perda de implantes foi múltipla. A principal complicação registrada se relacionou com inflamação dos tecidos peri-implantares e higiene bucal deficiente. Em 15 pacientes necessitou-se excisionar o tecido hiperplásico peri-implantar, além de enfatizar-se a necessidade de cuidados redobrados quanto à higiene bucal.

DONATSKY ${ }^{67}$, em 1993, reabilitou 25 pacientes consecutivamente, sendo 19 mulheres e 6 homens com idade entre 40 e 80 anos, apresentando atrofia do osso mandibular. Foram inseridos 93 implantes Brånemark suportando sobre-dentaduras através de encaixes em forma de bola. O período de observação variou de 12 a 27 meses, com média de 18 meses. O índice de sucesso global dos implantes individuais, após um ano, foi de 97\% e o das próteses de 100\%. Não foi observada nenhuma complicação protética ou cirúrgica persistente. A partir destes resultados preliminares, indicou-se como alternativa bem sucedida, a associação de implantes Brånemark suportando sobre-dentaduras com encaixes em forma de bola.

Foi apresentado também em 1993, por HENRY; TOLMAN; BOLENDER 91 , a aplicabilidade de implantes osseointegrados Brånemark no tratamento de pacientes parcialmente desdentados, durante três anos. Este trabalho consistiu em continuação daquele realizado por VAN STEENBERGHE 195, em 1990, no qual os pacientes foram avaliados após um ano. Participaram 9 centros clínicos, nos quais foram tratados 169 pacientes. Destes 58\% pertenciam ao sexo feminino e $42 \%$ ao masculino, com idade entre 18 a 70 anos. Em 68 maxilas e 91 mandibulas, um total de 558 implantes foram instalados. Destes, 528 foram conectados por intermediário no segundo estágio cirúrgico. Após a cicatrização, 521 fixações suportaram 197 próteses. Os seguintes parâmetros clínicos foram registrados: indice de placa, gengivite, profundidade de sondagem, indice de sangramento, mobilidade dentária, 
estabilidade protética e função estomatognática. As modificações na altura óssea ao redor das fixações foram medidas radiograficamente. Após três anos, 460 fixações suportando 174 próteses em 139 pacientes permaneceram no estudo. O índice de sobrevivência global acumulado dos implantes foi de 93.9\%. A maior parte das perdas ocorreram em implantes de menor comprimento e nos localizados na maxila, com índice acumulado de perda de 7.5\%, em oposição aos 5.2\% da mandíbula. Em relação à qualidade óssea, estavam localizados em osso tipo III e IV, 28 dos 33 implantes que falharam. Nenhuma correlação foi observada entre ocorrência de falhas e sexo do paciente neste estudo, como também foi relatado por VAN STEENBERGHE195 na avaliação inicial. A maior parte das complicações cirúrgicas se resolveram entre o primeiro e terceiro ano de acompanhamento e somente 5 parestesias residuais (4\%) se mantiveram. Os índices gengival e de placa apresentaram-se similares entre dentes naturais e intermediários, refletindo nivel de controle aceitável. A altura do osso marginal foi determinada em $0.1 \mathrm{~mm}$ anualmente, durante todo o acompanhamento. O índice acumulado de estabilidade da prótese foi de $98.5 \%$, 95.8\% e 94.8\% respectivamente para o primeiro, segundo e terceiro ano. A complicação mais freqüente relacionada às próteses foi fratura do material da superficie oclusal.

JEMT; LEKHOLM102, no mesmo ano, trataram e acompanharam durante 5 anos 67 pacientes parcialmente edêntulos consecutivos, sendo 31 mulheres e 36 homens com idade entre 22 e 78 anos. Estes apresentavam-se com classe I e II de Applegate-Kennedy, e foram reabilitados com próteses de extremo livre suportadas por implantes. Em 70 maxilares foram inseridos 259 implantes sobre os quais conectou-se 94 próteses. Durante o período de acompanhamento clínico e radiográfico, sete pacientes abandonaram o estudo. Foram perdidos e removidos sete implantes, o que, no entanto não influenciou a estabilidade das próteses. O índice de sobrevivência global acumulado foi de $97.2 \%$ e $100 \%$, respectivamente para os implantes e próteses. Mensurou-se, através de radiografias periapicais convencionais perda óssea marginal média nos implantes de $0.8 \mathrm{~mm}$ na maxila e de $0.6 \mathrm{~mm}$ na mandíbula. O problema clínico mais freqüente foi fadiga e fratura da resina veneer, como também perda dos parafusos de ouro. 
Foi investigada a efetividade clínica de implantes Brånemark na reconstrução protética unitária por SCHMITT; ZARB180, em 1993. Selecionouse 32 pacientes tratados consecutivamente, 17 homens e 16 mulheres com idade entre 16 e 63 anos, nos quais inseriu-se 40 fixações. Destas, 28 foram posicionadas na maxila e 12 na mandíbula. Utilizaram para avaliação o critério de sucesso proposto por SMITH; ZARB ${ }^{186}$, no ano de 1989. O tempo de acompanhamento após a conexão da prótese variou de 1.4 a 6.6 anos e todos os implantes permaneceram em função, obtendo-se $100 \%$ de sucesso. Os dados sugeriram que os resultados foram favoráveis à adaptação da técnica de osseointegração aos pacientes necessitando de reconstrução unitária suportada por implante.

Em estudo longitudinal, NEVINS; LANGER ${ }^{154}$, no ano de 1993, avaliaram a utilização de implantes Brånemark nas áreas posteriores. Foram tratados 338 pacientes parcialmente edêntulos, com idade entre 18 a 89 anos, no período entre 1984 e 1991. Inseriu-se ao todo 1203 fixações, destas 551 na mandíbula e 652 na maxila. O índice de sucesso foi obtido pela avaliação dos implantes segundo os critérios propostos por ALBREKTSSON e colaboradores $^{15}$, em 1986. O índice de sucesso dos implantes na mandíbula foi de $95.5 \%$, com a falha de 25 fixações. Foram confeccionadas 247 próteses em 200 mandíbulas, das quais 8 falharam com índice de estabilidade da prótese de $97 \%$. Na maxila, 31 implantes falharam, com índice de sucesso de $95.2 \%$. Das 250 próteses realizadas em 193 maxilas, somente 2 falharam, com índice de sucesso superior a $99 \%$. 
Foi realizado, em 1993, estudo prospectivo, por VAN STEENBERGHE et al. ${ }^{196}$, envolvendo 9 centros em 3 continentes. Os autores relataram os aspectos periodontais relacionados aos dentes naturais e implantes de titânio, após três anos de observação. Foram acompanhados, em 169 pacientes, 558 implantes suportando 197 próteses desconectadas dos dentes naturais. Durante o período de observação, o número de implantes reduziu para 460 e o de próteses para 174. O índice de sucesso acumulado para os implantes desde sua inserção foi de $94.3 \%$ após 2 anos, e de 93.9\% depois de 3 anos. As falhas se concentraram em pacientes com alto indice de placa. A perda óssea marginal medida através de radiografias pela técnica do paralelismo, no primeiro ano perdeu-se $0.4 \mathrm{~mm}$, enquanto durante o segundo e terceiro ano foi de $0.03 \mathrm{~mm}$ ao ano em média. Não se detectou inflamação gengival intensa em nenhum dos pacientes e o índice de placa e gengivite apresentaram-se com dados similares em volta dos intermediários e dos dentes. A profundidade de sondagem reduziu significativamente durante os três anos de acompanhamento.

ZARB; SCHMITT209, em 1993, avaliaram a efetividade clínica de implantes Brånemark no tratamento de 30 pacientes parcialmente edêntulos na região anterior da maxila e mandíbula. Foram posicionados 94 implantes em 34 áreas edêntulas anteriores. Utilizou-se os critérios de sucesso propostos por SMITH; ZARB ${ }^{186}$. Permaneceram em função 47 (94\%) dos 50 implantes posicionados na maxila e 39 (88.6\%) dos 44 inseridos na mandíbula, após período de atuação das cargas oclusais variando de 2 a 8 anos. O índice de sucesso global foi de $91.5 \%$. Com isso concluiu-se que as experiências com osseointegração em pacientes completamente desdentados podem ser replicadas em parcialmente edêntulos. 
Realizou-se comparação, em 1993, por SCHARF, TARNOW179, do índice de sucesso obtido até o segundo ato cirúrgico de implantes posicionados sob condições de "limpeza", em relação às "estéreis". Cirurgias "estéreis" foram realizadas em centro cirúrgico sob protocolo extremamente rígido de esterilização. As cirurgias sob condições de "limpeza" ocorreram em clínica convencional. Em 61 casos, foram posicionados 273 implantes sob condições "estéreis", obtendo-se índice de sucesso das fixações de 98.9\% e de 95\% para as próteses. Em condições de "limpeza", foram inseridos 113 implantes em 31 casos, com índice de sucesso da fixação e da prótese, respectivamente, de 98.2\% e 93.5\%. As diferenças entre os índices de sucesso não foram consideradas estatisticamente significantes. Conclui-se a partir dos resultados desta análise, que a cirurgia de colocação dos implantes pode ser realizada tanto em condições "estéreis" quanto de "limpeza" e alcançar o mesmo índice de sucesso de osseointegração clínica.

No ano seguinte, CORDIOLI; CASTAGNA; CONSOLATI 54 , compilaram os dados clínicos obtidos com reconstruções unitárias suportadas por implantes osseointegrados. A amostra incluiu 47 pacientes, sendo 30 do sexo feminino e 17 do masculino, com idade entre 16 e 67 anos. Foram inseridos 67 implantes, destes 48 de $3.75 \mathrm{~mm}$ de diâmetro e 19 mini-implantes de $3.0 \mathrm{~mm}$. Foram confeccionadas em porcelana 40 próteses e, em metalocerâmica, 27. Os implantes foram acompanhados a cada 4 meses no primeiro ano e a cada 6 meses no período subseqüente. Este período de avaliação variou de 6 meses a 5 anos, com média de 26 meses. Obteve-se índice de sobrevivência de 94.4\%, devido à perda de 3 implantes. Durante a segunda fase cirúrgica, removeu-se dois implantes e nove meses após a instalação da prótese, mais um foi perdido. Detectou-se a presença de placa bacteriana em $19.2 \%$ das superficies examinadas e inflamação gengival em 5.8\% dos sítios, registrando-se também a ausência de mucosa ceratinizada em 10\% das superficies vestibulares e em $7.5 \%$ das linguais. A média de profundidade de sondagem foi de $3.4 \mathrm{~mm}$ e $43.7 \%$ dos sítios demonstraram sangramento à sondagem. 
Neste mesmo ano, EKFELDT; CARLSSON; BÖRJESSON69, relataram avaliação clínica de restaurações unitárias suportadas por implantes Brånemark, durante período de 14 a 55 meses. Em 77 pacientes, dos quais 30 mulheres (39\%) e 47 homens (61\%) com idade entre 20 a 70 anos, foram posicionados 93 implantes para confecção de próteses unitárias. Somente 2 fixações foram perdidas, uma antes da conexão do intermediário e outra durante o primeiro ano em função. Necessitaram de reajustes 43\% dos parafusos dos intermediários durante o período de acompanhamento, e por este motivo, 9 coroas cimentadas precisaram ser substituídas. A análise radiográfica demonstrou perda óssea em 14 fixações, variando de 0.6 a 1.8 $\mathrm{mm}$, ou seja, envolvendo 1 a 3 roscas. Entretanto, em 71 implantes não se detectou nenhuma alteração.

GRANSTRÖM et al.80, em 1994, analisaram 258 implantes posicionados na região craniofacial. Destes, 88 localizavam-se em osso não irradiado de 26 pacientes, 80 em osso irradiado de 32 pacientes e 45 em osso irradiado pós-tratamento com oxigênio hiperbárico em 10 pacientes. Participaram do estudo 68 pacientes, sendo 44 homens e 24 mulheres, subdivididos nos três grupos acima mencionados. O tratamento por oxigênio hiperbárico foi realizado por 90 minutos diariamente, sendo 20 vezes antes e 10 após inserção do implante. O tempo de acompanhamento médio foi de 62.1 meses. Durante o período de investigação, 13 pacientes morreram, sendo 10 do grupo dos irradiados, 2 do controle e 1 dos submetidos à oxigenação hiperbárica. Detectou-se perda acentuada dos implantes em osso irradiado (38.4\%) em comparação com os do osso não irradiado (17\%). Nenhum dos implantes posicionados, após o tratamento com oxigênio hiperbárico foi perdido. Correlacionando-se a dose de radiação com os locais de perda de implantes, pode-se concluir que as doses de radiação mais reduzidas não preveniram a perda de implantes. A interposição de período mais longo entre aplicação da radiação e primeira fase cirúrgica dos implantes resultou em aumento no percentual de implantes perdidos. Foi indicada redução do tempo entre aplicação da radiação e cirurgia de inserção dos implantes. A área com perda mais acentuada de implantes foi a do osso peri-orbital. Os implantes com $3 \mathrm{~mm}$ de comprimento apresentaram mais falhas do que os de $4 \mathrm{~mm}$ ou 
maiores. A maior parte dos implantes do grupo submetido à radiação foi perdida durante os três primeiros anos. No grupo controle, a maior parte dos implantes foram perdidos durante o primeiro ano, após o qual se estabeleceu um platô. No grupo tratado por oxigênio hiperbárico, observou-se índice de perda estável durante os primeiros cinco anos.

CARLSON; CARLSSON ${ }^{49}$, no ano de 1994, relataram resultados obtidos a partir da coleta dos dados transversais relativos ao tratamento de 600 próteses suportadas por implantes Brånemark consecutivos examinadas por 16 clínicas da Suécia. Englobou-se as consultas de manutenção e de urgência durante dois meses. Em 28\% dos casos necessitou-se de tratamento protético variando desde reembasamento até a substituição da prótese. A complicação mais freqüente se relacionou com a fratura da resina acrílica da prótese e da oclusal dos dentes, desgaste ou defeito estético. A frequência das complicações foi mais acentuada na maxila do que na mandíbula e variou em ordem decrescente da sobre-dentaduras, seguida da tipo protocolo, das próteses parciais e por fim os elementos unitários. A falha foi de $0.3 \% \mathrm{em}$ 2.709 implantes e ocorreu em $1 \%$ dos pacientes examinados.

GUNNE; JEMT; LINDÉN84, no mesmo ano de 1994, apresentaram continuação de estudo de VAN STEENBERGHE 195, do ano de 1990. Foi realizada a avaliação após três anos dos dados coletados em múltiplos centros. Reabilitou-se pacientes parcialmente edêntulos por próteses parciais fixas suportadas por implantes Brånemark. Em 164 pacientes, 58\% de mulheres e $42 \%$ de homens com idade entre 18 e 70 anos, inseriu-se 521 fixações. Foram conectadas 197 próteses de extremo livre em 60 maxilas e 91 mandíbulas. Ao final do estudo, $12.6 \%$ dos pacientes abandonaram o estudo restando 139 dos 164 iniciais. O indice de sucesso acumulado foi de 94.8\% e 93.9\%, respectivamente para as próteses e implantes. A maior parte das próteses perdidas estavam suportadas somente por dois implantes. A complicação mais freqüente foi fratura e perda dos parafusos de ouro, principalmente nas próteses suportadas por dois implantes. 
As próteses fixas e sobre-dentaduras suportadas por implantes foram comparadas por HEMMINGS; SCHMITT; ZARB88, no ano de 1994, abordando-se: número de complicações, tratamentos suplementares realizados e manutenção necessária. Utilizou-se amostra de 50 pacientes, nos quais posicionou-se consecutivamente próteses fixas e sobre-dentaduras mandibulares. Estas foram acompanhadas uma vez ao ano, durante 5 anos. $\mathrm{O}$ sucesso do implante foi definido através de algumas condições clínicas e radiográficas: imobilidade quando testado individualmente, após a remoção da prótese, ausência radiográfica de radioluscidez peri-implantar e perda óssea ao redor dos implantes inferior a $0.2 \mathrm{~mm}$ ao ano, mucosa peri-implantar saudável e sem complicações persistentes mensuradas através de índices gengivais e periodontais. Durante os 5 anos de acompanhamento, 25 sobre-dentaduras suportadas por 68 implantes obtiveram indice de sucesso de 92.6\%. Em relação às 25 próteses fixas suportadas por 132 implantes o índice foi de $90.16 \%$. No primeiro ano, os ajustes pós-inserção foram mais comuns nas sobre-dentaduras. Entretanto, subseqüentemente, as próteses fixas apresentaram mais complicações, necessitando de maior número de consultas do que as sobre-dentaduras por ano, respectivamente, de 2.27 e 1.57 consultas. Nas próteses fixas, as complicações mais freqüentes estavam associadas à mucosa peri-implantar, fratura do parafuso do intermediário e da prótese, e falha dos componentes em resina acrílica. Em relação às sobredentaduras, ocorreram com mais frequência, durante a manutenção, fratura ou reativação do clipe devido à perda da efetividade, além de alterações dos tecidos moles peri-implantares com inflamação ou hiperplasia.

Investigou-se, no ano de 1994, a possivel ocorrência da perda de parafusos de ouro e do intermediário. Com este intuito, KALLUS; BESSING ${ }^{113}$ avaliaram próteses tipo protocolo suportadas por implantes Brånemark após 5 anos, analisando diversos parâmetros clínicos. Além disso, a estabilidade individual do implante e o indice de sobrevivência foram registrados, como também a adaptação da supra-estrutura e o nível de ajuste do parafuso de ouro. A amostra consistiu de 50 pacientes com próteses fixas suportadas por 283 implantes em função durante 5 anos, com idade variável de 66 a 68 anos, sendo mulheres e 14 homens.

Destes, 89 
posicionados em 16 maxilas e 194 em 34 mandibulas. Foram perdidos 5 implantes entre a primeira e segunda fase cirúrgica, em 278 fixações conectaram-se 50 próteses totais fixas. A adaptação desta foi avaliada através de escala modificada, baseada nos princípios da Associação Dentária Californiana (CDA) para mensuração da qualidade dos tratamentos dentários. Nesta escala, a partir dos níveis de qualidade clínica e

performance profissional dividiam-se os resultados em duas categorias principais: "satisfatória" e "não aceitável". O indice "satisfatório" se subdividia em duas subfrações: "excelente" e "aceitável", enquanto o índice "não aceitável" fracionou-se em "possíveis inadequações no futuro" e "inadequações presentes". Os critérios foram adaptados para determinar a firmeza dos parafusos do intermediário e de ouro. Estes foram avaliados pela realização de reajustes manuais: "sem perda" equivale a "excelente", e não se consegue apertar o parafuso individual manualmente; "pequena perda" similar a "aceitável", o parafuso não se soltará, mas possivelmente aumentará a mobilidade ao ser submetido à resistência contínua; "obviamente perdido" equivalendo a "possíveis inadequações no futuro", no qual o parafuso poderia ser rotacionado mais do que uma volta sem resistência, contudo a fricção pode ser percebida continuamente enquanto o aperta; similar a "inadequações presentes" o indice "extremamente perdido", onde o parafuso deveria ser bastante rotacionado antes de encontrar fricção e nenhuma resistência foi encontrada na aplicação de torque manual. Os implantes foram submetidos à percussão utilizando-se uma sonda e a presença de som metálico claro consistiu indicador de osseointegração. Após remoção da prótese, o acúmulo de placa em cada intermediário e cilindro de ouro foram visualmente examinados estabelecendo-se um índice variável de 0 a 3 . A adaptação da supra-estrutura foi estabelecida através de escala em quatro graus: 0-ausência de discrepância visível; 1-discrepância pequena, indicando elevação clara da supra-estrutura com espaço menor que $0.5 \mathrm{~mm}$; 2-discrepância moderada de aproximadamente 0.5 a $1.0 \mathrm{~mm}$; 3-discrepância pronunciada com espaço claramente maior do que $1 \mathrm{~mm}$. Radiograficamente considerou-se exposição das roscas ao nível ósseo e existência de radioluscidez peri-implantares. Dos 278 implantes, somente um foi removido e o índice de sobrevivência foi de 
99.6\%. Foram classificados como "não aceitáveis" $26 \%$ dos parafusos de ouro. Em relação aos parafusos do intermediário, 4\% foram enquadrados nesta categoria. A percentagem dos níveis 2 e 3 de retenção de placa foi de, respectivamente, $29 \%$ e $44 \%$ na mandíbula e na maxila de $12 \%$ e $25 \%$. Os índices de adaptação da supra-estrutura variaram de 0 a 1 em 38 próteses. Correlacionou-se a perda dos parafusos de ouro com a falta de adaptação da prótese. Em alguma extensão, esta foi relacionada com experiência e habilidade do profissional, a partir das comparações dos resultados obtidos entre os três profissionais participantes deste estudo.

LANEY et al. ${ }^{124}$, em 1994, relataram continuação do estudo apresentado por JEMT et al. ${ }^{106}$, do ano de 1991, realizado em 7 centros diferentes durante um ano. Avaliou-se a reconstrução protética unitária suportada por implantes Brånemark durante 3 anos. Dos 92 pacientes tratados inicialmente, 82 permaneceram neste estudo de 3 anos. Após um ano em função, $97.2 \%$ dos implantes sobreviveram em 88 pacientes, e entre o primeiro e terceiro ano $100 \%$ dos implantes sobreviveram em 82 pacientes. Permaneceram estáveis $89.6 \%$ das próteses e o índice acumulado de sucesso dos implantes foi de $97.2 \%$. Nenhuma alteração foi observada nos diversos parâmetros clínicos registrados anteriormente: gengivite, profundidade de sondagem, sangramento à sondagem, e mobilidade dos implantes e dentes. A reabsorção óssea marginal radiograficamente mensurada permaneceu inferior a $0.1 \mathrm{~mm}$ durante o segundo e terceiro ano. Ocorreram perdas do parafuso intermediário, entretanto em nivel significativamente reduzido em relação ao primeiro ano. 
Neste mesmo ano, LEKHOLM et al. ${ }^{129}$, apresentaram continuação do estudo de VAN STEENBERGHE et al. ${ }^{195}$, do ano de 1990. Inicialmente, 169 pacientes parcialmente edêntulos, com idade entre 17 e 70 anos, foram tratados pelo sistema de implantes Brånemark em 9 centros de diversos países. Os pacientes foram acompanhados durante 5 anos em estudo prospectivo, enfocando o sucesso dos implantes e a estabilidade das próteses. Os seguintes parâmetros foram registrados, em volta dos dentes e implantes: indice de placa e gengival e profundidade de sondagem. O nivel ósseo marginal em volta dos implantes foi determinado através de radiografias periapicais pela técnica do paralelismo. Além destes dados, reportaram a função estomatognática e possiveis complicações. Os critérios de falha adotados foram: mobilidade dos implantes, presença de problemas persistentes e incuráveis no tecido mole, complicações mecânicas em volta ou afetando a unidade de ancoragem e perda óssea radiográfica alcançando o terço apical da fixação. Inicialmente, 558 fixações foram inseridas em 68 maxilas e 91 mandíbulas e classificadas como classe I, II e IV de Applegate-Kennedy. No segundo ato cirúrgico, 528 implantes foram reexpostos, dos quais 521 foram conectados a 197 próteses fixas (76 na maxila e 121 na mandíbula), no total de 164 pacientes. Durante o período de acompanhamento não se reexaminou 27 (16\%) pacientes e 116 implantes, estes ou abandonaram (80 implantes) o estudo ou foram excluídos por não suprir os critérios de avaliação propostos (36 implantes). O índice acumulado de sucesso dos implantes foi de 92\% na maxila e 94\% na mandíbula, com índice global de estabilidade das próteses de 94\%. O indice de placa e gengivite apresentaram-se com padrão de saúde similar tanto em volta dos dentes naturais, quanto dos intermediários de titânio. A perda óssea marginal média para todos os implantes durante os cinco anos foi de $0.8 \mathrm{~mm}$ na maxila e $0.5 \mathrm{~mm}$ na mandíbula. As complicações mais freqüentes foram fratura da resina e perda dos parafusos de ouro. Conclui-se, que resultados seguros e previsiveis puderam ser obtidos, durante 5 anos, em pacientes parcialmente edêntulos reabilitados por próteses suportadas por implantes osseointegrados. 
Foi relatada a experiência com implantes craniofaciais Brånemark na Universidade da California (UCLA), no ano de 1994, por ROUMANAS176 e colaboradores. Estes foram utilizados na retenção de próteses maxilo-faciais, durante 6 anos. Em 30 pacientes foram inseridos 92 implantes, sendo 70 de 3 $\mathrm{mm}$ e 22 de $4 \mathrm{~mm}$ de comprimento. Destes implantes, 71 suportaram próteses craniofaciais, 8 foram subseqüentemente recobertos devido a problemas teciduais persistentes e 16 falharam na obtenção ou manutenção da osseointegração. O índice de sucesso total foi de $73.3 \%$ e variou de acordo com a localização dos implantes ou com a incidência de radiação. O osso temporal obteve o maior índice de sucesso (92.5\%), seguido do assoalho da fossa nasal $(72.2 \%)$ e por último a órbita (65\%). Os pacientes irradiados, em média 4500 rads, apresentaram índice de sucesso de 68.4\%, enquanto nos não irradiados o índice de sucesso foi de 85.3\%. Sugeriram a partir dos dados obtidos, a seleção cuidadosa e tratamento com precauções dos pacientes submetidos à radioterapia.

ANDERSSON 17 et al., no ano seguinte, discorreram sobre resultados e experiências adquiridas no acompanhamento prospectivo de implantes osseointegrados suportando reconstruções unitárias. Foram avaliados, no grupo A, 57 pacientes com idade entre 14 e 56 anos, dos quais 33 homens e 24 mulheres. Nestes foram inseridos 65 implantes, sendo 3 na mandíbula e 62 na maxila, e acompanhados durante 2 anos. O grupo B englobou 34 indivíduos, sendo 16 do sexo feminino e 18 do masculino, com idade entre 14 e 56 anos. Neste segundo grupo foram posicionados 37 implantes, que foram acompanhados por período de três anos. Utilizou-se exclusivamente o sistema CeraOne para confecção da prótese unitária, sendo 95\% realizada em cerâmica e 5\% em metalo-cerâmica. Somente um implante foi perdido, com presença de mobilidade acentuada duas semanas após a cimentação da prótese. O índice de sucesso acumulado foi de 98.5\% no grupo A, entre segundo e terceiro ano. Este índice foi de $97.3 \%$ no grupo B entre o terceiro e o quarto ano. As próteses obtiveram 95\% de sucesso, e somente 4 coroas foram classificadas como falha. 
BECKER; BECKER37, no ano de 1995, apresentaram estudo retrospectivo sobre implantes osseointegrados substituindo molares. Foram acompanhados 22 pacientes com idade entre 48 e 73 anos, destes 16 mulheres e 6 homens. Nestes inseriu-se 24 implantes consecutivamente, sendo 21 de $3.75 \mathrm{~mm}$ de diâmetro, 1 de $4 \mathrm{~mm}$ e 2 de $5 \mathrm{~mm}$. Os 18 implantes mandibulares e 6 maxilares foram acompanhados durante 2 anos em média. O índice acumulado de sucesso, após um ano foi de 95.7\%. Em 61.9\% das próteses, os parafusos de ouro permaneceram estáveis. Necessitaram de substituição uma vez $14.2 \%$ dos parafusos, duas vezes $9.5 \%$ e três vezes $14.3 \%$. Relacionou-se o sucesso com a conjunção de diversos fatores: qualidade e quantidade óssea adequadas, comprimento o mais longo quanto anatomicamente possivel e exclusão dos pacientes com hábitos para-funcionais. Estes foram descritos como fator de risco relacionado à fratura do implante e perda do parafuso de ouro, devido à incidência de forças excessivas.

Em 1995, CARTER; HUNTER50, descreveram utilização durante periodo de 6 anos dos implantes Brånemark, em relação ao índice de falhas observado. Considerou-se a fixação como osseointegrada quando, na segunda fase cirúrgica, esta permanecesse fixa no osso, e com presença de evidência clínica e radiográfica de contato íntimo do tecido ósseo com o implante. Em 70 pacientes parcialmente edêntulos, sendo 39 mulheres e 31 homens com idade entre 16 a 78 anos, inseriu-se 160 implantes. Nenhuma fixação perdeu a integração, apenas uma utilizada para suportar prótese parcial fraturou, e outra foi removida e substituída por se localizar em posição anatomicamente inaceitável. O índice de retenção das fixações foi superior a 99\%.

Foram acompanhados 76 implantes posicionados em 71 pacientes, destes 35 mulheres e 36 homens com idade entre 13 e 65 anos, suportando reconstruções protéticas unitárias por HAAS et al.85, em 1995. Em 69 implantes utilizou-se o sistema CeraOne para confecção da prótese. Foram acompanhados 20 implantes durante 12 meses, 35 por 24 meses, 17 por 36 meses, 3 por mais de 36 meses e 1 durante 66 meses. O indice de sobrevivência foi de $96.3 \%$ dos implantes, utilizando-se os critérios de sucesso 
de ALBREKTSSON et al.15. A complicação mais freqüente consistiu na perda do parafuso de ouro em 12 casos.

Neste mesmo ano, HENRY e colaboradores ${ }^{92}$, acompanharam em estudo multicentro, a reposição protética unitária suportada por implantes osseointegrados. Foram tratados 43 pacientes, destes 29 do sexo masculino e 14 do feminino, com idade entre 16 e 60 anos. Utilizou-se 4 implantes de 4 mm de diâmetro, e o restante com $3.75 \mathrm{~mm}$. As consultas de reavaliação foram após 1 semana, e 1, 6, 12, 24, 36, 48 e 60 meses, após a inserção da coroa. Os seguintes parâmetros clínicos foram registrados: sangramento à sondagem, presença de gengivite, profundidade de sondagem, e mobilidade do implante entre dois instrumentos. Os índices obtidos se apresentaram similares nos implantes e nos dentes adjacentes. O exame radiográfico foi realizado com técnica do paralelismo, após 1 semana e 1 ano de instalação da prótese. A média de perda óssea radiográfica na altura do osso marginal com 1 ano foi de $0.25 \pm 0.62 \mathrm{~mm}$. Utilizou-se o sistema CeraOne para confecção de 98\% das próteses. Após a inserção da prótese registrou-se um caso de mobilidade do parafuso do intermediário e 2 casos de repetição da coroa associada com desadaptação da infra-estrutura. No primeiro ano de função da prótese registrou-se as seguintes complicações: um caso de perda do parafuso do intermediário e outro de fratura da coroa resultando na necessidade de refazer a reconstrução, perda do parafuso do intermediário angulado e falha na cimentação necessitando repeti-la. O indice de sobrevivência obtido foi de 98.2\% com a falha de somente um implante anteriormente à conexão do intermediário.

Investigou-se, em estudo prospectivo, o índice de sobrevivência de implantes osseointegrados em pacientes parcialmente edêntulos, acompanhados durante 3 anos por HIGUCHI; FOLMER; KULTJE95, em 1995. O trabalho consistiu em continuação do acompanhamento da mesma amostra realizado por VAN STEENBERGHE ${ }^{193}$, no ano de 1989. Após três anos de inserção das próteses, 460 implantes suportavam 174 próteses fixas em 139 pacientes. Obteve-se nesta amostra índice de sobrevivência acumulado de 93.9\% com três anos. Entretanto, não foram incluídos os implantes 
adormecidos e os dos pacientes que abandonaram o estudo. Os implantes de menor comprimento (7-, 10- e 13-mm) apresentaram percentual de falhas superior aos dos mais longos. Além disso, o índice acumulado de falhas na maxila $(7.5 \%)$ se manteve superior ao da mandibula (5.2\%). Comparando-se esses resultados obtidos depois de 3 anos com os de um ano, não se manteve a tendência de concentração das falhas nos pacientes do sexo masculino. Localizavam-se em osso tipo III e IV 85\% dos implantes perdidos. Os implantes que falharam durante o segundo e terceiro ano continuaram se concentrando em pacientes com índice de placa inicialmente alto. Em relação à perda óssea marginal, esta se apresentou superior na maxila com um valor médio de 0.13 e 0.10 , respectivamente para os sítios mesiais e distais. Na mandíbula os valores obtidos foram de 0.02 para ambos os sítios. Antes da atuação das forças oclusais, falharam 20 implantes e, após a instalação da prótese, 13 implantes foram removidos em três anos. O índice acumulado de falhas foi de 4.1\%, 5.7\% e $6.1 \%$, respectivamente para o primeiro, segundo e terceiro ano.

OLSSON et al. ${ }^{160}$, neste mesmo ano, apresentaram a continuação do estudo de FRIBERG; GRÖNDAHL; LEKHOLM74 do ano de 1992. Os resultados apresentados consistiam em extensão do estudo piloto conduzido intra-individualmente em 103 pacientes. Estes consistiam em 54 mulheres e 49 homens, com idade entre 33 a 83 anos. Em cada indivíduo foi inserido um implante teste auto-rosqueável e outro controle convencional, ambos Brånemark. Foram tratados na mandíbula 70 pacientes, e 33 na maxila. Posicionou-se 288 implantes no grupo teste e 275 como controle. O sucesso acumulado e o indice de sobrevivência foram calculados de acordo com a análise pela tabela de vida proposta por ALBREKTSSON, ZARB ${ }^{13}$, no ano de 1993. O índice de sobrevivência acumulado e reabsorção óssea marginal apresentaram resultados equivalentes, tanto para os implantes do grupo teste, quanto para os do grupo controle. O índice de sobrevivência acumulado após três anos foi de $87.9 \%$ e $86.8 \%$ na maxila e de $99.5 \%$ e $100 \%$ na mandíbula para, respectivamente, implantes teste e controle. A média da perda óssea marginal variou aproximadamente entre $0.5 \mathrm{~mm}$ no grupo controle e $0.6 \mathrm{~mm}$ no grupo teste, após três anos em função. Contudo, após o primeiro ano nenhum dos dois grupos excedeu perda de $0.1 \mathrm{~mm}$ anuais. Concluiu-se que os 
implantes auto-rosqueáveis apresentaram efetividade clínica e radiográfica similar aos implantes convencionais.

Em continuação do artigo de HENRY; ADLER; WALL ${ }^{89}$, com os dados de 2 anos do ano de 1986, HENRY; BOWER; WALL90, em 1995, avaliaram em estudo retrospectivo de 10 anos 15 pacientes totalmente edêntulos reabilitados por próteses fixas suportadas por 83 implantes. Monitorou-se os implantes pelo registro de parâmetros clínicos (indice de placa e gengival, profundidade de sondagem, sangramento à sondagem, nível de inserção), radiografias periapicais pela técnica do paralelismo e panorâmicas. Inquiriu-se os pacientes através de questionário sobre a satisfação com tratamento ressaltando-se vantagens e desvantagens deste. As respostas dos pacientes a este foram indicativos de satisfação com o tratamento, sendo citado como principal desvantagem a dificuldade de higienização. Todos os parâmetros clínicos avaliados apresentaram-se com melhora significativa, durante os 10 anos. Mensurou-se a perda óssea radiograficamente no primeiro ano variando de 0 a $1.2 \mathrm{~mm}$ e no período subseqüente de 0.01 a $0.06 \mathrm{~mm}$. Registrou-se como principal complicação dos tecidos moles a presença de hiperplasia peri-implantar associada ao controle inadequado da placa bacteriana. Em dois casos recorreu-se à excisão cirúrgica do tecido hiperplásico e nos outros reforçou-se os métodos de higiene bucal. Nenhuma das fixações foi removida e a estabilidade das próteses foi de 100\%. As fraturas dos componentes da prótese encontram-se representadas na Tabela $n^{\circ} .2$ e as necessidades relativas à manutenção da prótese na Tabela $n^{\circ}$. 3. Os parafusos fraturados foram enviados para avaliação por microscopia de varredura e as imagens apresentaram-se compativeis com fadiga por estresse. 
Tabela n. 3: Demonstração dos componentes que fraturaram das próteses fixas totais suportadas por implantes osseointegrados, durante período de avaliação de 10 anos do estudo de HENRY; BOWER; WALL90, em 1995.

\begin{tabular}{l|l|lr|l|l}
\hline Ano & Material oclusal & $\begin{array}{l}\text { Parafuso } \\
\text { fixação } \\
\text { prótese }\end{array}$ & $\begin{array}{l}\text { fratura do } \\
\text { da }\end{array}$ & Fixação \\
parafuso do & ditermediário & \\
\hline 1 & 4 & - & - & - \\
\hline 2 & 4 & - & - & - \\
\hline 3 & 2 & - & - & - \\
\hline 4 & 3 & - & - & - \\
\hline 5 & 1 & - & - & - \\
\hline 6 & 3 & - & 3 & - \\
\hline 7 & 2 & 2 & 1 & 1 \\
\hline 8 & 2 & - & - & - \\
\hline 9 & 2 & - & 4 & - \\
\hline 10 & - & - & - & - \\
\hline Total & 23 & 2 & 8 & 1 \\
\hline
\end{tabular}


Tabela n. 4 : Apresentação das necessidades de tratamento durante 10 anos de manutenção das próteses fixas totais suportadas por implantes osseintegrados do estudo de HENRY; BOWER; WALL 90 , em 1995

\begin{tabular}{|c|c|c|c|c|c|c|}
\hline Ano & Reposição & Extensão & \begin{tabular}{l|l|} 
do & Confecção
\end{tabular} & Reposição de & Reembasou & Confecção \\
\hline & de dente & cantilever & dade & dente & prótese & nova \\
\hline & na prótese & prótese & $\begin{array}{l}\text { infra- } \\
\text { estrutura }\end{array}$ & prótese total & total & prótese total \\
\hline$\overline{1}$ & - & - & - & - & - & - \\
\hline 2 & $\mathbf{1}$ & 1 & - & - & - & 1 \\
\hline 3 & - & - & 1 & 1 & 1 & 1 \\
\hline 4 & - & $F$ & - & - & - & - \\
\hline 5 & 1 & 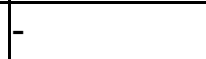 & 1 & - & - & 1 \\
\hline 6 & - & $\mathbf{1}$ & $\mathbf{1}$ & $\mathbf{1}$ & $\mathbf{1}$ & 2 \\
\hline 7 & $\mathbf{1}$ & - & - & $\mathbf{1}$ & 1 & 1 \\
\hline 8 & - & - & - & - & - & $\mathbf{1}$ \\
\hline 9 & - & 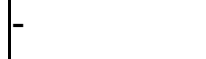 & $\mathbf{1}$ & - & - & - \\
\hline 10 & - & - & - & - & - & - \\
\hline Total & 3 & 2 & 4 & 3 & 3 & 7 \\
\hline
\end{tabular}


AVIVI-ARBER; ZARB ${ }^{26}$, no ano de 1996, relataram e efetividade clínica de reconstruções unitárias suportadas por implantes. $\mathrm{Na}$ amostra monitorou-se 41 pacientes com 49 próteses unitárias, destes 1 fixação não se osseointegrou na segunda cirurgia, sendo que 42 destes implantes em 35 pacientes foram acompanhados durante 1 a 8 anos. Utilizou-se como critério de sucesso o de SMITH; ZARB ${ }^{186}$, de 1989, e classificou-se os implantes na tabela de quatro campos de ALBREKTSSON; ZARB ${ }^{13}$, do ano de 1993. Foi administrado questionário avaliando-se satisfação do paciente com o tratamento obtendo-se 94\% de aceitação destes. Radiograficamente observouse perda óssea de 0.03 na face mesial e 0.11 na distal a cada ano, sendo compativel com o máximo proposto de $0.2 \mathrm{~mm}$ ano. Entretanto, em 9 implantes obteve-se mais de $0.2 \mathrm{~mm}$ ao ano de perda óssea e em 2 destes a perda se apresentou progressiva. Registrou-se como complicação mais freqüente a perda do parafuso de titânio da prótese e do intermediário associada a presença de fístula. Esta complicação se solucionou com substituição por parafuso de ouro e torque deste com motor apropriado. Cinco coroas veneer fraturaram-se e foram confeccionadas novamente.

A continuação do estudo com 1 ano de JEMT et al.1106, de 1991, e LANEY et al. ${ }^{124}$, em 1994, por 3 anos, foi apresentada por HENRY e colaboradores $^{93}$, no ano de 1996 com 5 anos de avaliação. Neste último, relatou-se continuação do acompanhamento multicentro prospectivo da reposição de elementos unitários suportados por implantes Brånemark. Inicialmente, posicionou-se 107 fixações em 92 pacientes, e ao final de 5 anos 75 pacientes e 86 implantes foram monitorados, com 18\% de pacientes sem retorno para manutenção. Nenhuma alteração foi observada nos diversos parâmetros clínicos registrados anteriormente: gengivite, profundidade de sondagem, sangramento à sondagem, e mobilidade dos implantes e dentes. Radiograficamente, a perda óssea não se apresentou superior a $1.0 \mathrm{~mm}$ nos 5 anos avaliados. O índice de sucesso acumulado foi de $96.6 \%$ na maxila e $100 \%$ na mandíbula. A complicação protética mais freqüente consistiu-se na perda do parafuso da prótese e esta se reduziu no decorrer dos 5 anos e com substituição do parafuso de titânio por ouro. 
Em 1996, ZARB; SCHMITT210, acompanharam 45 pacientes consecutivos totalmente edêntulos em estudo prospectivo sobre efetividade da sobre-dentadura suportada por implantes osseointegrados. Em 5 maxilas inseriu-se 17 implantes e em 42 mandíbulas 115 fixações. O período de acompanhamento variou de 3 a 13 anos, com consultas de revisão anualmente. $\mathrm{Na}$ segunda cirurgia removeu-se 3 implantes, outros 3 permaneceram adormecidos e 2 foram removidos no segundo e terceiro ano após a instalação da prótese. Relatou-se ocorrência dos seguintes problemas estruturais sendo apresentado entre parênteses o número registrado nos primeiros três anos e após a barra o número destes registrado entre 3 e 13 anos: fratura do parafuso de ouro (4/0); fratura da barra (2/0); fratura da composição barra/clipe (2/4); fratura do magneto mantenedor do parafuso (5/3); fratura da resina acrílica $(1 / 0)$. As seguintes necessidades de tratamento foram relacionadas como mais comuns: apertar parafusos da prótese, apertamento da composição barra-clipe; modificação da porção acrílica da prótese prevenindo a impacção de alimentos na região anterior sobre a barra; reembasamento ou ajuste das áreas de resina posterior. Concluiu-se que a reabilitação de pacientes através de sobre-dentaduras se relacionou com conforto, estabilidade e retenção adequados a longo prazo nos indivíduos com história de desadaptação crônica das dentaduras.

Em 1996, JEMT e colaboradores ${ }^{108}$, avaliaram em estudo multicentro prospectivo sobre-dentaduras suportadas por implantes osseointegrados por 5 anos. Os dados foram recolhidos em 9 multicentros de diversos países. Foram acompanhados 30 pacientes com 117 implantes Brånemark inseridos na maxila e 103 com 393 implantes posicionados na mandíbula. Durante os 5 anos, 35 pacientes (26.3\%) com 127 implantes abandonaram o monitoramento sendo que 17 por falta de cooperação e em seis pacientes foram removidas todas as fixações retornando a utilizar prótese total. O critério de sucesso empregado consistiu na estabilidade da fixação e estrutura de suporte da sobre-dentadura com ausência de dor ou radioluscência peri-implantar. O índice de sucesso acumulado dos implantes e sobre-dentaduras na maxila foi de, respectivamente, $72.4 \%$ e $77.9 \%$ e na mandíbula de $94.5 \%$ e $100 \%$. Considerou-se as condições de qualidade e 
quantidade iniciais do tecido ósseo como fator contribuinte para obtenção de índices de sucesso acumulado superiores na mandíbula. A média da perda óssea marginal foi de $0.8 \mathrm{~mm}(0.8)$ e $0.5 \mathrm{~mm}(0.8)$ durante os cinco anos na maxila e mandíbula respectivamente. Através da medida do topo do intermediário até a margem da gengiva detectou-se recessão média de $0.2 \mathrm{~mm}$ da mucosa peri-implantar da mandibula, enquanto que na maxila registrou-se hiperplasia média de $0.5 \mathrm{~mm}$.

DE BRUYN et al.60, em 1997, descreveram a opinião obtida por meio de questionários sobre satisfação e função, emitida por pacientes reabilitados por próteses suportadas por implantes Brånemark. Estes foram tratados por dentistas sem experiência anterior, que acabavam de concluir pós-graduação em reabilitação com implantes osseointegrados. A comparação se realizou entre 3 períodos: antes do tratamento, 4 meses depois deste e 3 anos após conclusão da prótese. Na amostra de 61 pacientes, 23 foram reabilitados por próteses totais fixas na mandibula (grupo A), 18 totais na maxila (grupo B) e 20 próteses parciais (grupo C). Inseriu-se 298 implantes, sendo que 7 falharam na segunda cirurgia (2.3\%) e 1 durante os 3 anos de acompanhamento (0.3\%). No grupo A necessitou-se de reparo na infraestrutura de 4 pacientes e 2 apresentaram-se com fratura nos dentes em resina; grupo B somente em um dente de acrílico registrou-se fratura; e no grupo $\mathrm{C}$ em 1 paciente registrou-se fratura da porcelana e outro da resina. Segundo grande maioria dos pacientes, relatava-se nos questionários coletados satisfação acentuada com o tratamento e conforto com mastigação, estética e fonética. Concluiu-se que reabilitação por implantes osseointegrados Brånemark realizada por equipe com pouca experiência pode apresentar-se com alta qualidade, melhorando a função e satisfazendo os anseios e exigências dos pacientes.

FRIBERG e colaboradores ${ }^{76}$, no ano de 1997, apresentaram a continuação dos estudos prospectivos de FRIBERG; GRÖNDAHL; LEKHOLM74 do ano de 1992, com um ano, e OLSSON et al. 160, 1995 com 3 anos. Na amostra englobou-se três centros com 103 pacientes, após 5 anos. Foram inseridos ao todo 288 implantes auto-rosqueáveis e 275 convencionais do 
sistema Brånemark. Em cada individuo foi inserido um implante teste autorosqueável (Mk-II) e outro controle convencional. Registrou-se perda de um implante na mandíbula e 26 na maxila, sendo 13 do grupo experimental e 13 do controle. O sucesso acumulado e índice de sobrevivência foram calculados de acordo com análise pela tabela de vida proposta por ALBREKTSSON, $Z_{A R B}{ }^{13}$, no ano de 1993. O índice de sucesso acumulado foi de $100 \%$ na mandibula e $87 \%$ na maxila, sendo que em 5 pacientes registrou-se mais de $85 \%$ das perdas. Radiograficamente nos dois tipos de implantes analisados, no primeiro ano registrou-se 0.3 a $0.4 \mathrm{~mm}$ de perda óssea, enquanto nos anos subsequentes aproximadamente $0.1 \mathrm{~mm}$ ao ano. $O$ percentual de sucesso acumulado da prótese foi de 97\%. Registrou-se fratura de uma infra-estrutura e 1 parafuso do intermediário. Concluiu-se que o índice de sucesso acumulado e perda óssea marginal radiográfica nos dois tipos de implantes avaliados se apresentou similar atestando a efetividade do Mk-II.

NIIMI e colaboradores ${ }^{157}$, no ano de 1997, acompanharam em estudo multicentro implantes posicionados em tecidos submetidos a radiação. Inseriu-se 118 implantes, sendo 110 intra-orais e 9 extra-orais, em 24 pacientes em 9 multicentros do Japão. Em 7 pacientes utilizou-se como terapia auxiliar o tratamento por oxigênio hiperbárico. Com esta detectou-se percentual de sucesso de $80 \%$ na maxila e $92.9 \%$ na mandíbula, e sem a terapia foi de $62.5 \%$ na maxila e $96.4 \%$ na mandibula. Registrou-se risco mais acentuado de perda de implantes mais curtos situados na maxila, do que os mais longos nesta.

SCHELLER e colaboradores ${ }^{182}$, no ano de 1998, apresentaram estudo multicentro prospectivo de avaliação dos resultados obtidos com reconstruções protéticas unitárias suportadas por implantes Brånemark. Acompanhou-se durante 5 anos 99 fixações em 82 pacientes, sendo 2 removidas na segunda fase cirúrgica e 97 restauradas com coroas unitárias cimentadas. No primeiro ano reavaliou-se 77 implantes clínica e radiograficamente pela técnica do paralelismo, no segundo 57, e no terceiro 47 . Registrou-se os seguintes parâmetros clínicos nos implantes: indice gengival segundo LÖE; SILNESS91; posição da margem da coroa (1-subgengival, 2-na 
margem gengival, 3-supragengival); mobilidade. Durante o período de avaliação, detectou-se problemas nos tecidos moles peri-implantares de 5 coroas que foram tratados e solucionados, 7 próteses e 4 parafusos da prótese de ouro se fraturaram necessitando-se repor estes e em 3 coroas necessitou-se recimentação. Nos índices clínicos não se registrou alterações discrepantes com manutenção da saúde do tecido peri-implantar, e radiograficamente no primeiro ano registrou-se $0.5 \mathrm{~mm}$ e depois $0.1 \mathrm{~mm}$ de perda óssea anualmente. Obteve-se $95.9 \%$ de sucesso acumulado para os implantes e $91.1 \%$ para as coroas. Os resultados se apresentaram compativeis com os critérios de sucesso propostos por ALBREKTSSON et al. ${ }^{15}$, de 1986.

ANDERSSON e colaboradores ${ }^{18}$, no ano de 1998, apresentaram resultados após 5 anos da continuação do estudo com 2 para 3 anos apresentado por ANDERSSON et al. ${ }^{17}$, em 1995. Os dados foram obtidos com 65 reconstruções unitárias tipo CeraOne suportadas por implantes Brånemark. Inseriu-se 62 implantes na maxila e 3 na mandibula em 57 pacientes. Registrou-se ausência de 8 pacientes (14\%) com 5 anos, sendo que somente 1 implante falhou 2 semanas depois da cimentação da prótese. Neste local inseriu-se outra fixação e esta foi acompanhada sem complicações durante 5 anos. O índice acumulado de sucesso dos implantes foi de $98.5 \%$ e das coroas de 93.7\%, com substituição de 4 coroas. Mensurou-se perda óssea por radiografias periapicais pela técnica do paralelismo obtendo-se no primeiro ano $1.3 \mathrm{~mm}$ e no período subsequente inferior a $0.2 \mathrm{~mm}$. Os tecidos moles periimplantares apresentaram-se saudáveis e com a cimentação e término do intermediário intrasulcular não se registrou nenhuma alteração ou recessão na mucosa peri-implantar. Aprovou-se os resultados obtidos com o CeraOne, sendo que este se apresentou com alta previsibilidade dos resultados e se eliminou os problemas relacionados a perda do parafuso da prótese. 
ANDERSSON e colaboradores ${ }^{19}$, no ano de 1998, compararam os resultados obtidos com a reabilitação de pacientes por reconstruções unitárias realizadas por especialistas e clínicos gerais. Acompanhou-se 38 pacientes, sendo 19 tratados por clínicos e os outros 19 por especialistas. Ao final dos 5 anos 3 pacientes (11\%) não compareceram e nenhum implantes foi removido obtendo-se índice de sucesso acumulado de 100\%. Um dos pacientes do grupo dos especialistas necessitou da substituição da coroa por esta ter se submetido a trauma excessivo obtendo-se índice de sucesso das próteses de $94.4 \%$, e de $100 \%$ no grupo dos clínicos. Mensurou-se a perda óssea por radiografias periapicais pela técnica do paralelismo, sendo de 0.4 e $0.2 \mathrm{~mm}$ no primeiro ano, respectivamente para os clínicos e especialistas, e menos de $0.1 \mathrm{~mm}$ nos dois grupos nos anos subsequentes. Não se diagnosticou diferenças clínicas e radiográficas discrepantes entre os dois grupos de profissionais. Concluiu-se que clínicos gerais submetidos a treinamento podem realizar tratamentos simples de forma similar aos especialistas, reservando para estes os casos mais complexos.

\section{8-IMPLANTES IMZ}

O sistema de implantes osseointegrados IMZ (cilindro intramóvel), foi introduzido na Alemanha desde 1978. Constitui-se de um cilindro de titânio puro, recoberto ou por camada de "spray" de plasma de titânio ou por hidroxiapatita. Em seu interior incorporou-se o elemento intramóvel (IME) com finalidade de simular a viscoelasticidade do ligamento periodontal do dente natural dissipando as forças incidentes sobre o pino do implante. O IME se associa à extensão transmucosa (TIE) de titânio polido em posição supragengival, acessivel à manutenção da higiene bucal como também ao controle pós-operatório e às subseqüentes trocas anuais dos elementos do IME. Este absorve os choques, distribuindo o estresse e forças funcionais de forma fisiológica, a fim de proporcionar em pacientes parcialmente edêntulos a reconstrução protética com esplintagem nos dentes naturais adjacentes. Os implantes IMZ estão disponiveis em dois diâmetros diferentes: 3.3 ou $4.0 \mathrm{~mm}$. O primeiro pode possuir os seguintes comprimentos- $8.0,10.0$ e $13.0 \mathrm{~mm}$, e o 
segundo- 8.0, 11.0, 13.0 e $16.0 \mathrm{~mm}$. Os implantes de $4.0 \mathrm{~mm}$ estão disponíveis sob duas formas, podendo ou não incorporar a extensão transmucosa (IME). O procedimento cirúrgico envolve 2 estágios, com a interposição de período de 90 a 120 dias entre estas fases. Este proporciona pós-operatório livre de cargas oclusais, durante o qual a osseointegração deverá se instalar28.

Foram avaliados, em 1993, por BABBUSH; SHIMURA 28, 1059 implantes IMZ inseridos em 322 pacientes, durante 5 anos. A amostra consistia em 216 mulheres e 106 homens com idade entre 16 e 86 anos. A análise pela tabela de vida foi utilizada para determinar o índice de sobrevivência dos implantes. Acompanhou-se os pacientes a cada três meses durante os primeiros dois anos e, no período subseqüente, em reavaliações anuais. Em 77\% dos casos, as fixações foram de $4.0 \mathrm{~mm}$ de diâmetro e em 33\% dos casos de $3.3 \mathrm{~mm}$. Estas apresentaram indice de sobrevivência inferior às primeiras. Em 12\% dos implantes inseridos a superficie possuía revestimento de hidroxiapatita e o restante camada de "spray" de plasma de titânio. Foram perdidos 28 implantes durante os 5 primeiros anos, dos quais 9 não se integraram no segundo ato cirúrgico. Em relação aos implantes restantes, 19 falharam por motivos periodontais ou protéticos. O indice de sobrevivência global acumulado durante 5 anos foi de 95\%. Foram inseridos para restaurar pacientes parcialmente edêntulos $75 \%$ dos implantes, com percentual de sobrevivência de 96\%. O indice de sobrevivência para pacientes totalmente edêntulos (25\%) também foi de 96\%. Na maxila posicionou-se 44\% das fixações e na mandíbula $66 \%$, com índice de sobrevivência de, respectivamente, $92 \%$ para a primeira e 99\% para segunda. Nas mulheres posicionou-se 66\% dos implantes, com nível de sobrevivência de 94\%, e nos homens 98\%. Sugeriram a correlação entre a utilização de implantes mais longos e de diâmetro superior, com o índice de sobrevivência positivo obtido neste estudo. 
Neste mesmo ano, FUGAZZOTO; WHEELER; LINDSAY77 analisaram os indices de sucesso e falha de implantes cilindricos inseridos em regiões de osso tipo IV. Das 1363 fixações inseridas, 513 foram posicionadas em osso tipo IV. Estas foram observadas em função, após o segundo ato cirúrgico, durante período variando de 0 a 60 meses. A definição de sucesso e falha se baseou nos critérios estabelecidos por ALBREKTSSON et al ${ }^{15}$, em 1986. Ocorreram 34 falhas, sendo que 22 destas em osso tipo IV, gerando índice de sucesso absoluto de 95.7\%. O índice geral de sucesso absoluto foi de 97.4\% para todas as fixações e 98.4\% em relação às inseridas em osso tipo I, II e III. Das 22 falhas, 8 ocorreram na segunda fase cirúrgica, 3 durante o primeiro ano de acompanhamento, e 11 após 24 a 36 meses em função. Sugeriu-se que o indice de sucesso alcançado pelos implantes cilindricos, poderia estar relacionado com a facilidade de obtenção da fixação primária destes. Este não necessitou de estabilização bicortical exigida nos implantes tipo parafuso, extremamente dificil de ocorrer no osso tipo IV. Além deste fator, cogitou-se possivel influência do elemento intra-móvel (IME) como redutor da sobrecarga oclusal.

Ainda no ano de 1993, FUGAZZOTO e colaboradores78, avaliaram os resultados obtidos com a utilização do IMZ em quatro clínicas privadas dos Estados Unidos. O total de 974 pacientes, variando de 17 a 83 anos, foram tratados com 2023 implantes consecutivos. Diversos tipos de reconstruções protéticas foram confeccionadas: reposição unitária, associação de implantes e dentes naturais em próteses fixas e próteses totais suportadas por implantes. Destas apenas as próteses unitárias não utilizaram o elemento intra-móvel (IME). Acompanhou-se os implantes em função por período de 6 a 60 meses, e a cada 6 meses removia-se a prótese e reavaliava-se esta. Os implantes foram classificados como falha na obtenção ou manutenção da osseointegração em presença de: dor, qualquer grau de mobilidade, supuração, radioluscidez periimplantar persistente ou perda óssea progressiva detectada radiograficamente, após o primeiro ano em função. O índice de sucesso absoluto foi de $96.4 \%$ e $98.4 \%$, respectivamente na maxila e mandibula. 
WIJS; CUNE; PUTTER200, em 1995, acompanharam durante 5 anos 173 implantes IMZ recobertos por hidroxiapatita, posicionados na região anterior da maxila de 81 pacientes, sendo 58\% de mulheres e $42 \%$ de homens, com idade entre 17 e 77 anos. Os implantes foram inseridos 3 meses ou mais, após extração do dente natural. A reconstrução protética consistia de próteses parciais fixas ou removiveis, e coroas unitárias. O percentual de sobrevivência acumulado dos implantes foi de $96.1 \%$ após três anos. Os resultados em relação à cor da mucosa foram classificados como "idealmente rosa" (indice modificado de LÖE;SILNESS135=0); "alguma vermelhidão" (indice modificado de LÖE;SILNESS135=1); "sangramento à sondagem" (índice modificado de LÖE;SILNESS135=2); e "sangramento espontâneo" (indice modificado de LÖE;SILNESS135=3). E os dados obtidos em relação a esta classificação foram os seguintes: indice 0- 55\% dos implantes, indice 1- 38.9\%, indice 2- 6.0\% e índice 3- 0\%. Quantificou-se a satisfação do profissional e do paciente, em respectivamente: a pobre: $2.9 \%$ e $7.2 \%$; b- moderada: $4.3 \%$ e $7.2 \%$; c- boa: $26.1 \%$ e $49.3 \%$; d- excelente: $66.7 \%$ e $36.2 \%$.

No ano de 1996, HAAS e colaboradores ${ }^{86}$, avaliaram em estudo retrospectivo a sobrevivência de 1920 implantes IMZ durante no máximo 100 meses. Obteve-se índice de sobrevivência acumulado dos implantes de 89.9\% após 60 meses e 83.2\% depois de 100 meses. Na análise pela tabela de vida revelou-se diferença estatisticamente significante entre maxila e mandíbula, sendo com 60 meses de respectivamente $71.6 \%$ e $93.9 \%$ e com 100 meses de $37.9 \%$ e $90.4 \%$. Os implantes inseridos na região anterior da maxila apresentaram-se com falha significativamente superior aos da porção posterior desta. Este padrão não se observou na mandíbula. Os seguintes fatores analisados não se apresentaram com influência estatisticamente significante no índice de sobrevivência acumulado: idade e sexo dos pacientes; nível de edentulismo (parcial ou totalmente edêntulos); tempo entre posicionamento do implante e extração do dente; comprimento e diâmetro da fixação. 


\section{9-IMPLANTES ASTRA TECH}

O sistema de implantes dentais Astra Tech consiste de fixações auto-rosqueáveis disponiveis no comprimento variando de 8 e $19 \mathrm{~mm}$, e com diâmetros de 3.5 e $4 \mathrm{~mm}$. A superficie pode se apresentar usinada ou jateada com dióxido de titânio. Os intermediários possuem 6 comprimentos diferentes variando de 0.0 a $7.5 \mathrm{~mm}$. Todos estes componentes são confeccionados em titânio comercialmente puro grau IV. O procedimento cirúrgico compreende duas etapas, inicialmente a inserção da fixação, três meses depois conecta-se o intermediário, e após a cicatrização tecidual confecciona-se a prótese ${ }^{23}$.

ARVIDSON et al.23, em 1992, acompanharam o tratamento do edentulismo mandibular utilizando o sistema de implantes dentais Astra Tech. A amostra foi constituida de 54 pacientes, dos quais 22 homens e 32 mulheres. A performance clínica de 310 implantes foi monitorada durante 3 anos, após conexão da prótese. Os exames anuais envolviam análise clínica e radiográfica. Estas foram utilizadas para avaliar a osseointegração das fixações e registrar o nivel do osso marginal utilizando as roscas como ponto de referência, já que cada uma destas mede $0.6 \mathrm{~mm}$. Os seguintes parâmetros clínicos foram registrados: índice de placa, de sangramento e de mobilidade e profundidade de sondagem. O índice de sobrevivência dos implantes individualmente fi de 98.1\% e para as próteses $100 \%$. As alterações ósseas desde o exame inicial até o final do primeiro ano variaram de $-0.4 \mathrm{a}+1.0 \mathrm{~mm}$ (mediana de 0.00), desde o primeiro até o terceiro ano foi de - 0.8 a $+0.6 \mathrm{~mm}$ (mediana de 0.04), e durante os três anos de $-1.1 \mathrm{a}+1.0 \mathrm{~mm}$ (mediana de 0.01 ). Não se detectou reabsorção óssea acentuada no primeiro ano, em comparação com os dois anos subseqüentes. Observou-se ganho ósseo significativo nos homens, entretanto, nas mulheres o nível não se alterou. Durante os três anos de acompanhamento, mais de $70 \%$ dos sitios apresentaram índice de placa 0 . Em 95\% dos sítios, não detectou-se sangramento à sondagem. A profundidade de sondagem variou de 0 a $2 \mathrm{~mm}$ em 96.3\% dos sítios e não houve mobilidade em 98.1\% dos 310 implantes. A partir destes dados, concluiu-se que não se 
registrou reações inflamatórias relevantes nos tecidos moles em volta dos implantes durante os três anos de acompanhamento.

No ano de 1996, DAVIS; ROGERS; PACKER ${ }^{58}$, relataram os aspectos relativos às complicações ocorridas na fase de manutenção de sobredentaduras utilizando magnetos ou encaixe em forma de bola durante 3 anos. Utilizou-se 54 implantes Astra Tech para suportar 25 sobre-dentaduras, sendo 12 retidas através da utilização de magnetos (Grupo 1) e 13 com encaixe em forma de bola (Grupo 2). Somente dois implantes no grupo 1 caracterizaram-se como falha, um destes seis meses após instalação da prótese e outro fraturouse no final do primeiro ano. Registrou-se em 3 anos 64 episódios de manutenção no grupo 1 e 63 no grupo 2. A maior parte dos episódios se registrou no primeiro ano, sendo no grupo 1 de 30 e no 2 de 34 . Não se relatou diferença estatisticamente significante entre os dois grupos. Registrou-se como complicação mais freqüente do grupo 1 e a segunda do grupo 2 os ajustes na dentadura devido ao conforto para o paciente ou alterações na oclusão. Neste grupo a primeira necessidade consistiu no reaperto do encaixe em forma de bola desrosqueado 23 vezes em 9 pacientes. Concluiu-se que em alguns pacientes necessita-se de visitas constantes para reajustes na fase de manutenção, entretanto em 16 dos 25 pacientes foram necessárias 8 ou menos consultas para reajustes durante 3 anos.

KARLSSON; GOTFREDSEN; OLSSON115, no ano de 1997, apresentaram estudo multicentro prospectivo de 47 implantes Astra Tech suportando próteses unitárias. Inicialmente a amostra englobava 47 pacientes, depois de um ano examinou-se 42 e com 2 anos 43. 
Nestes nenhum implante foi removido obtendo-se índice de acumulado de sucesso de $100 \%$. A perda óssea mensurada radiograficamente pela técnica do paralelismo foi de $0.31 \mathrm{~mm}(0.48 \mathrm{~mm})$. Registrou-se poucas complicações sendo a mais freqüente a recimentação das próteses.

MAKKONEN ${ }^{137}$, em 1997, avaliaram 155 implantes instalados em 33 pacientes totalmente edêntulos durante 5 anos. Usualmente inseriu-se 6 fixações para prótese fixa e 4 para sobre-dentaduras com barra Dolder. Na segunda cirurgia removeu-se 2 implantes sem entretanto comprometer-se o plano de tratamento e os pacientes foram reabilitados por sobre-dentaduras suportadas por 3 implantes. Mensurou-se a média da perda óssea, através de radiografias periapicais pela técnica do cone longo, obtendo-se $0.48 \mathrm{~mm}$ para os reabilitados por prótese fixa e $0.56 \mathrm{~mm}$ nos com sobre-dentadura durante os 5 anos. O índice de sucesso acumulado foi de $98.7 \%$, sendo de 100\% nas próteses fixas e $97.4 \%$ nas sobre-dentaduras. O sucesso das próteses foi de 100\%. Concluiu-se que o sistema de implantes Astra Tech proporciona alternativa de tratamento confiável e previsivel a médio prazo.

PALMER e colaboradores ${ }^{161}$, no ano de 1997, em estudo prospectivo de elementos unitários suportados por implantes Astra Tech com superfície jateada por dióxido de titânio. Durante 2 anos a cada 6 meses, monitorou-se 15 pacientes, nos quais foram inseridas 15 fixações. Não se detectou nenhum implante perdido, nem fratura do parafuso do intermediário. Não se registrou problemas nos tecidos moles e a morfologia e saúde destes foi bem mantida. Necessitou-se recimentar uma coroa e outra fraturou-se na borda incisal e foi reconfeccionada. Através de radiografias periapicais pela técnica do paralelismo mensurou-se a perda óssea que se apresentou estatisticamente insignificante. Concluiu-se que a reconstrução de elementos unitários com o sistema Astra Tech apresenta-se com alto índice de sucesso clínico e radiograficamente alterações ósseas mínimas. 
KARLSSON; GOTFREDSEN; OLSSON116, no ano de 1998, reportaram acompanhamento durante 2 anos de 50 pacientes parcialmente edêntulos reabilitados por sistema de implantes Astra Tech. Estes apresentavam-se com dois tipos diversos de superficies: usinada e jateada com partículas de dióxido de titânio. Foram instaladas 133 fixações, sendo 48 na maxila e 85 na mandíbula, suportando 52 próteses parciais. O período de avaliação foi de 2 anos obtendo-se índice de sucesso acumulado de $97.7 \%$ e $95.7 \%$, respectivamente, para os implantes e próteses. A perda óssea foi avaliada radiograficamente sendo de $0.24 \mathrm{~mm}(0.69 \mathrm{~mm})$ durante os 2 anos. Não se detectou diferenças estatisticamente significativas no percentual de sucesso e no nivel de perda óssea radiográfica entre os dois tipos de superfície.

No mesmo ano, ARVIDSON et al. ${ }^{24}$, reportaram a continuação com 5 anos do estudo de acompanhamento prospectivos de implantes do sistema Astra Tech de 3 anos, apresentado em 1992 também por ARVIDSON e colaboradores $^{23}$. Na amostra englobou-se os 54 pacientes com 310 implantes da primeira avaliação e 53 individuos com 308 fixações. Entretanto, 16 pacientes abandonaram o estudo e a amostra final foi de 91 indivíduos com 517 fixações. Registrou-se percentual de sucesso acumulado dos implantes de 98.7\% e da prótese de 100\%. Os sítios monitorados apresentaram-se com 82\% das faces com ausência de placa, 96.8\% sem sinais de inflamação e profundidade de sondagem de $1.37 \mathrm{~mm}$ no exame inicial, e $1.48,1.39$ e 1.31 $\mathrm{mm}$ com 1,3 e 5 anos. Acompanhou-se os implantes radiograficamente obtendo-se respectivamente a seguinte variação de valores com 1,3 e 5 anos, +0.45-1.42 mm, +0.57-1.73 $\mathrm{mm} \mathrm{e} \mathrm{+0.72-2.44} \mathrm{mm.} \mathrm{De} \mathrm{acordo} \mathrm{com} \mathrm{os} \mathrm{critérios}$ de sucesso de ALBREKTSSON e colaboradores ${ }^{15}$, do ano de 1986, empregados no estudo concluiu-se que o sistema de implantes Astra Tech preencheu os requisitos na amostra de 91 pacientes avaliados em 5 anos. 


\subsection{0-IMPLANTES ENDOPORE}

Denominou-se sistema Endopore devido a "Endo" significar endósseo e "pore" se relacionar a geometria da superfície porosa que recobre a fixação. O sistema de implantes Endopore possui forma de cone truncado confeccionado em liga de titânio (Ti6A14V), recoberto por multicamadas de partículas sinterizadas esféricas de liga de titânio (Ti6Al4V) e na porção coronal envolvida por colar liso de $1.0 \mathrm{~mm}$. Com esta superficie porosa obtêm-se estrutura tridimensional repleta de poros e canais, na qual o osso se imbrica tridimensionalmente. Através da geometria da superfície proporciona-se aumento considerável da área de superfície possibilitando-se utilização de implantes de menor comprimento. Os implantes apresentam-se com 3.5, 4.1 e $5 \mathrm{~mm}$, sendo o primeiro com $9 \mathrm{~mm}$ de comprimento, o segundo com 7, 9 e 12 $\mathrm{mm}$, e o terceiro com 5, 7, 9 e $12 \mathrm{~mm}$. Os implantes se inserem em duas fases cirúrgicas e entre estas respeita-se o período mínimo de 12 semanas $^{64}$.

No ano de 1986, DEPORTER e colaboradores ${ }^{62}$, avaliaram histologicamente a cicatrização inicial adjacente a implantes de liga de titânio recobertos por microesferas sinterizadas formando camada porosa de liga de titânio. A amostra foi de 6 cães beagle, nos quais inseriu-se 2 implantes em cada lado da mandíbula. O sacrificio dos animais se realizou com 4 e no outro grupo com 8 semanas. Nos cortes histológicos procedeu-se a análise qualitativa e morfométrica. Apenas 1 dos 24 implantes não se integrou e a cicatrização óssea se estabilizou alcançando platô em 4 semanas. A partir dos resultados obtidos sugeriu-se que sob as condições do experimento não existiram vantagens em se alongar o período entre a primeira e segunda fase cirúrgica além de 4 semanas ${ }^{64}$.

No ano de 1991, PILLIAR e colaboradores ${ }^{165}$, avaliaram a influência do conformação do implante no remodelamento ósseo. Utilizou-se três tipos diferentes de implantes dentais endósseos: 1.forma de parafuso (titânio c.p.); 2.superficie recoberta completamente por partículas sinterizadas de liga de titânio formando camada porosa (liga de titânio- $\mathrm{Ti}_{6} \mathrm{Al}_{4} \mathrm{~V}$ ); 3 . superfície 
recoberta nos dois terços apicais por partículas sinterizadas de liga de titânio formando camada porosa (liga de titânio-Ti6 $\mathrm{Al}_{4} \mathrm{~V}$ ). Os implantes foram inseridos em cães e mantidos em função, sendo durante 32 semanas do tipo 2 e entre 73 a 77 semanas do tipo 1 e 3 . O implante do tipo 2 só se manteve em posição durante 32 semanas em vez das 77 pretendidas inicialmente devido à presença de infecção em 22 dos 32 implantes inseridos em 8 cães. Os implantes do tipo 1 e 3 foram colocados em 6 cães, sendo dois de cada tipo em lados contralaterais. Após esta fase sacrificou-se os animais e relatou-se em outro artigo os resultados histológicos. Registrou-se a presença de perda na crista óssea em todos os tipos analisados. Entretanto não se detectou presença de perda significativa no do tipo 2 na ausência de sinais de inflamação da mucosa periimplantar. Sugeriu-se que a diferença observada se justificaria a partir dos diferentes estados de estresse desenvolvido no osso circundante aos três implantes analisados. Concluiu-se que a conformação do implante influi diretamente no padrão de remodelação óssea. Sugeriu-se duas possiveis causas associadas à perda óssea da crista peri-implantar, durante o primeiro ano, após a inserção da prótese. A primeira se relaciona com infecção tecidual local devido à presença de microorganismos provenientes da cavidade bucal na interface implante-tecido. A segunda hipótese se desenvolve a partir da presença de estresse mecânico anormal atuando na crista óssea periimplantar. Não somente estresse reduzido resulta nesta perda devido à presença de atrofia por desuso,como também estresse acentuado provocando microfraturas e reabsorção subseqüente do osso em contato com a fixação.

MORGAN; JAMES; PILLIAR ${ }^{150}$, neste mesmo ano, investigaram as possíveis causas da falha mecânica dos componentes de fixação do sistema Brånemark. As superficies de cinco espécimes clínicos fraturados após permanecerem em função, durante 1 a 5 anos, foram comparados com espécimes novos fraturados em laboratório ao se submeter a forças excessivas ou cíclicas controladas. Ao nível de microscopia eletrônica de varredura, detectou-se estrias na superficie fraturada dos espécimes clínicos. Estas apresentaram compatibilidade com a dos espécimes submetidos a forças cíclicas indutoras da fadiga, em contraste com as superficies com depressões daqueles sujeitos à sobrecarga. Esta investigação demonstrou que as fraturas 
do componente da fixação ocorreram por fadiga, devido à atuação contínua de forças fisiológicas, agravada pela perda de osso alveolar marginal ao redor do implante. Sugeriu-se o monitoramento clínico e radiográfico em intervalos regulares dos pacientes detectando-se possiveis perdas ósseas precocemente, além de confirmar a manutenção da harmonia oclusal e distribuição equilibrada das forças nos implantes.

No ano de 1992, DEPORTER et al.63, relataram os resultados obtidos com o acompanhamento de 52 pacientes totalmente edêntulos por 2 anos. Em cada um dos pacientes inseriu-se 3 implantes na porção anterior da mandibula, sendo 153 implantes suportando 52 sobre-dentaduras. Desta amostra 2 pacientes morreram. Na avaliação se englobou radiografias padronizadas com suporte do filme conectado diretamente ao intermediário, e exame de sangue quanto a presença de Ti, Al e V. Registrou-se perda óssea somente no primeiro ano de $0.43 \mathrm{~mm}$ e esta se estabilizou no segundo ano em $0.17 \mathrm{~mm}$. Não se detectou alterações significativas no nível sanguíneo de Ti, Al e V. Detectou-se na segunda cirurgia perda de 3 implantes em um paciente, e dois indivíduos com perda de um implante cada. Todos os pacientes que apresentaram-se com perda de implantes eram fumantes contumazes. O percentual de sucesso dos implantes foi de $96.8 \%$.

DEPORTER e colaboradores ${ }^{64}$, no ano de 1996, apresentaram os dados obtidos com 3 para 4 anos de acompanhamento de 48 dos inicialmente 52 pacientes totalmente edêntulos relatados em 1992. Foram inseridos 3 implantes em cada paciente reabilitado por sobre-dentaduras. Os implantes foram monitorados clínica e radiograficamente com suporte padronizado. O índice de sucesso acumulado foi de $94.8 \%$. A análise dos dados radiográficos apresentou-se com média de perda óssea de $0.43 \mathrm{~mm}$ no primeiro ano, 0.17 $\mathrm{mm}$ no segundo e $0.13 \mathrm{~mm}$ no terceiro ano. 
No ano seguinte, LEVY et al.131, avaliaram índices periodontais em comparação com altura óssea medida radiograficamente, do grupo de pacientes descritos por DEPORTER et al. em $1992^{63}$ e 199664, entre 3 a 4 anos de função. Em 48 pacientes totalmente edêntulos com 3 implantes cada registrou-se: indice de placa e de sangramento a sondagem, profundidade de sondagem, nivel de inserção, mobilidade através do Perioteste e alterações ósseas por radiografias padronizadas. Mensurou-se perda óssea radiograficamente de 0.43 $\mathrm{mm}$ com 1 ano, $0.17 \mathrm{~mm}$ com 2 anos, $0.13 \mathrm{~mm}$ após 3 anos e ganho ósseo de + $0.05 \mathrm{~mm}$ com 4 anos. Detectou-se ausência de placa em 50\% das superficies, $79 \%$ sem sangramento a sondagem, e não se estabeleceu correlação entre a ocorrência destes dois parâmetros simultâneos. A média da profundidade de sondagem foi de $3.1 \mathrm{~mm}$ e em $64 \%$ dos sítios inferior a $3.5 \mathrm{~mm}$. O Perioteste médio foi de -4.35 com $96 \%$ dos valores situados em -0.5. Não se estabeleceu correlação entre mobilidade e alterações no nível de inserção, entre altura óssea e indice de placa ou entre altura óssea radiográfica e índice de sangramento a sondagem.

DEPORTER et al., em 199866, relataram o monitoramento variando de 6 meses a 2 anos de 20 pacientes reabilitados com 33 reconstruções unitárias suportadas por implantes Endopore. Coletou-se os seguintes dados: mobilidade através do Perioteste, radiografias padronizadas com posicionador conectado ao intermediário, indice de placa, profundidade de sondagem, sangramento à sondagem e nível de inserção. Apresentou-se os dados obtidos com o Perioteste e as radiografias, sendo que os outros dados clínicos coletados serão divulgados em outra publicação. Na maior parte dos sítios não se detectou nenhuma perda radiográfica e os valores apresentaram-se com variação de -1.2 a +0.7 com 1 ano. A maioria dos valores do Perioteste se situou entre 0 e valores negativos, e observou-se tendência dos valores negativos aumentarem progressivamente em função do tempo. Após seis meses 16 implantes, depois de 1 ano 14 e após 2 anos 13 implantes se mantiveram em função. 
DEPORTER e colaboradores 65 , no mesmo ano, relataram acompanhamento de 6 para 7 anos da amostra de 52 pacientes inicialmente apresentada em $1992^{63}$ e 199664, sendo que 46 destes foram examinados. Utilizou-se os seguintes critérios para determinar o sucesso do implante: índice gengival que não excedesse 2, segundo LÖE; SILNESS ${ }^{135}, 1965$; mobilidade através do Perioteste; ausência de dor; ausência de radioluscência periimplantar; perda óssea radiograficamente mensurada sem exceder $1 \mathrm{~mm}$ no primeiro ano e $0.2 \mathrm{~mm}$ nos anos subsequentes, profundidade de sondagem em torno de $3 \mathrm{~mm}$. Após 5 anos em função, um dos pacientes que perdeu um implante na segunda cirurgia, apresentou-se com os outros dois implantes com mobilidade e estes foram removidos. Não se detectou indice gengival superior a 2; dor e radioluscência foram detectados somente nos implantes que falharam; a perda óssea depois do primeiro ano foi em média de $0.06 \mathrm{~mm}$; profundidade de sondagem média de $2.87 \mathrm{~mm}$. O índice de sucesso preenchendo os critérios citados acima foi de $93.4 \%$ com 5 para 6 anos, e este permaneceu similar para o período de 6 para 7 anos.

\subsection{1-IMPLANTES ITI}

Foram desenvolvidos pelo International Team of Implantology (ITI)Grupo Internacional para Implantes Odontológicos- juntamente com o Instituto Straussman, da cidade de Waldenburg na Suiça. Nos estudos iniciais denominou-se osseointegração de "anquilose funcional" e objetivou-se simplificar cirúrgica e proteticamente a terapia por implantes. Os implantes ITI são confeccionados em titânio recoberto por "spray" de plasma de titânio com o intuito de aumentar a área de superficie. Estes possuem três tipos básicos: cilindro-perfurado, parafuso-perfurado e parafuso, disponíveis em versões de um e dois estágios cirúrgicos. Na conformação do implante cilindro-perfurado considerou-se as medidas verticais e horizontais do osso residual disponível nas diferentes áreas edêntulas da mandíbula ou maxila. A partir deste pressuposto, desenvolveu-se 5 formas diferentes denominadas: "C", "E", "F", "H" e "K". Seleciona-se então a forma mais adequada para ser inserida no osso 
disponivel. Com os orificios existentes no implante objetiva-se maximizar a área da superfície de contato para integração óssea, e diminuir a quantidade óssea removida durante preparação do sítio de inserção da fixação. Além disso, visava-se reduzir volume do implante quando comparado com a conformação dos implantes sólidos. Os implantes de titânio da versão de uma só fase cirúrgica, são intencionalmente não submersos e inseridos através de um procedimento cirúrgico único, e conexão da prótese final após período de 90 $\operatorname{dias}^{27}$. O implante tipo parafuso consiste de um parafuso de titânio autorosqueável que pode se inserir em uma ou duas fases cirúrgicas, recoberto por camada de "spray" de plasma de titânio, e também se denomina de TPS. Estes possuem conformação que pode ser subdividida em: cabeça, pescoço, ombro e corpo com forma de parafuso. Quando se insere em um único estágio cirúrgico, imediatamente após a colocação dos implantes incorpora-se uma barra. Após resolução do edema cirúrgico submete-se imediatamente às cargas oclusais $27,44,45$.

Em 1990, BUSER, WEBER e BRÄGGER44 descreveram a avaliação pré-cirúrgica e o procedimento cirúrgico propriamente dito no tratamento de 70 pacientes parcialmente edêntulos, dos quais 37 mulheres e 33 homens com idade entre 18 e 77 anos, nos quais inseriu-se 111 implantes ITI do tipo parafuso-perfurado durante 3 anos. Os seguintes critérios foram utilizados com a finalidade de determinar a presença de uma integração bem sucedida:

1-Ausência de queixas subjetivas pelo paciente

2-Os tecidos moles peri-implantares não apresentem infecção

visivel

3-Estabilidade do implante sem a detecção de mobilidade

4-Ausência de radioluscidez peri-implantar

5-Possibilidade de confecção protética adequada

Após um período de 3 meses, apenas um implante $(0,9 \%)$ falhou devido a uma infecção peri-implantar, e os outros 110 implantes foram restaurados proteticamente.

No mesmo ano, BUSER; WEBER; LANG45, avaliaram a integração de 100 implantes ITI, sendo 70 do tipo parafuso-perfurado e 30 cilindro- 
perfurado. Estes foram consecutivamente posicionados em 70 pacientes parcialmente edêntulos, e acompanhados durante 1 ano a cada três meses. Os seguintes parâmetros clínicos foram registrados: indice de placa, indice de sangramento, profundidade de bolsa, distância entre o ombro do implante e a margem da mucosa, nível de inserção, largura da mucosa ceratinizada, mobilidade do implante manualmente e utilizando-se o Perioteste e radiografias periapicais padronizadas pela técnica do paralelismo. Foi apresentado em $87.5 \%$ dos sítios escore 0 no índice de placa e em $80 \%$ dos sítios não se detectou sangramento. A profundidade de bolsa em mais de $80 \%$ dos sítios foi de $3 \mathrm{~mm}$ ou menos, e a largura média da mucosa ceratinizada foi de $3.26 \mathrm{~mm}$. Em 98\% dos implantes não se detectou mobilidade. Analisando-se os dados obtidos, cada implante foi classificado como sucesso ou falha de acordo com os cinco critérios citados acima no estudo de BUSER; WEBER; BRÄGGER ${ }^{44}$, do ano de 1990. Todos os pacientes se mantiveram no estudo. Após 12 meses de acompanhamento, 98\% dos implantes preencheram os critérios de sucesso pré-citados, sendo que os $2 \%$ de falhas apresentadas ocorreram durante o período de manutenção. Este se iniciou, após o periodo de cicatrização, que englobou os três primeiros meses depois da inserção do implante, no qual não se registrou nenhuma falha.

No ano de 1994, MERICSKE-STERN144 e colaboradores, avaliaram os resultados obtidos após 5 anos de acompanhamento de implantes ITI suportando sobre-dentaduras. Foram inseridas 66 fixações ITI tipo F de um só estágio cirúrgico na mandíbula de 33 pacientes. Os implantes conectaram-se a prótese através do sistema barra/clipe ou por intermediários em forma de bola. Monitorou-se o tecido peri-implantar logo após a instalação da prótese e depois anualmente, registrando-se os seguintes parâmetros: indice gengival e de sangramento a sondagem, profundidade de sondagem, quantidade de mucosa ceratinizada, nível de inserção. A média da profundidade de sondagem foi de 3 $\mathrm{mm}$, reduziu-se significativamente o índice de placa e o sangramento a sondagem com o decorrer do estudo e o nível de inserção permaneceu estável. Em 50\% dos implantes detectou-se presença de menos de $2 \mathrm{~mm}$ de mucosa ceratinizada, entretanto manteve-se a saúde peri-implantar independentemente da presença desta. Registrou-se falha de 2 implantes, 
sendo um por lesão peri-implantar com 2 anos e outro por fratura com 4 anos. No final e início do estudo, realizaram-se tomadas ortopantomográficas, a fim de se acessar as estruturas ósseas peri-implantares. Detectou-se através deste exame pequenos defeitos ósseos angulares em $16(22 \%)$ implantes de 12 pacientes e a profundidade de sondagem destes sitios se apresentou ligeiramente maior. Registrou-se perda de inserção significantemente reduzida quando os implantes foram inseridos, após período de edentulismo superior a 5 anos. Concluiu-se, que os implantes ITI suportaram as sobre-dentaduras mantendo a saúde dos tecidos peri-implantares durante 5 anos, independentemente da quantidade de mucosa ceratinizada e do período de tempo de edentulismo anteriormente a instalação desta.

Em 1995, WISMEYER; VAN WAAS; VERMEEREN202, apresentaram os resultados obtidos com o acompanhamento de 64 sobre-dentaduras suportadas por 218 implantes ITI, acompanhadas durante período médio de 80 meses, variando de 66 a 119 meses. A amostra compreendeu 19 homens e 45 mulheres, os quais foram avaliados através de um questionário sobre o tratamento realizado. Neste os pacientes registraram o grau de satisfação com a retenção e função da prótese. Os resultados obtidos no questionário ao final do período de acompanhamento foi satisfatório e os dados se apresentaram bastante similares aos anteriores com 18 meses. Após este período em 7\% dos pacientes registrou-se com alterações na sensibilidade da área do lábio inferior. O implante tipo TPS de $4 \mathrm{~mm}$ de diâmetro foi inserido em um único estágio cirúrgico. Após 10 a 12 semanas, conectou-se a sobre-dentadura à barra Dolder, através de um clipe interno. Ocorreram 7 falhas nos 218 implantes posicionados. Na manutenção das próteses, 9\% necessitaram reparo nos clipes, $7 \%$ fraturaram as sobre-dentaduras e em $28 \%$ destas realizou-se reembasamentos. 
Em 1995, LEIMOLA-VIRTANEN e colaboradores ${ }^{127}$, apresentaram estudo de avaliação de 39 pacientes nos quais se inseriu 153 implantes ITI. Em 37 pacientes posicionou-se 4 fixações na mandíbula totalmente edêntula, e em 2 pacientes foram 3 implantes, suportando sobre-dentaduras. Utilizou-se os seguintes critérios para avaliar o sucesso: implante funcionando adequadamente como suporte da sobre-dentadura; ausência de dor, mobilidade clínica e radioluscidez peri-implantar. Registrou-se a falha de 13 implantes em 6 pacientes no período de 3 a 10 anos com média de 5.6 anos de acompanhamento. Os seguintes parâmetros foram monitorados: índice de placa e gengival, mobilidade. Em 55 implantes (39\%) não se detectou presença de placa e 53\% sem gengivite. A partir de ortopantografias mensurou-se a perda óssea anual em $0.25 \mathrm{~mm}(0.29 \mathrm{~mm})$, não se observou perda nenhuma em 37 (26.4\%) implantes. O indice de sucesso foi de $91.5 \%$.

No ano de 1997, NISHIMURA e colaboradores ${ }^{158}$, avaliaram os parâmetros periodontais de 32 implantes osseointegrados ITI na mandíbula. Examinou-se 12 pacientes, durante 4 anos com 6, 12, 24, 36 e 48 meses. Utilizou-se os seguintes parâmetros: indice de placa, sangramento a sondagem, profundidade a sondagem, nivel de inserção e mobilidade com Perioteste. Através dos exames radiográficos periapicais pela técnica do paralelismo registrou-se nos quatro anos perda óssea de $3.5 \mathrm{~mm}(0.6 \mathrm{~mm})$. O índice de sucesso dos implantes foi de $100 \%$ e estes apresentaram-se com ausência de sinais de inflamação e mobilidade com o Perioteste. A profundidade de sondagem média foi de $2.09 \mathrm{~mm}$ e o nível de inserção de $2.55 \mathrm{~mm}$ nos quatro anos. Concluiu-se, que não foi possivel se estabelecer o valor diagnóstico dos parâmetros periodontais extrapolados para os implantes, mediante a ausência de complicações registradas neste estudo. 
No mesmo ano, BUSER et al. ${ }^{47}$, apresentaram estudo multicentro prospectivo durante 8 anos de 2.359 implantes ITI em pacientes parcial e totalmente edêntulos. $\mathrm{Na}$ amostra analisou-se pela tabela de vida 1.003 pacientes consecutivos, sendo 597 (59.5\%) mulheres e 406 (40.5\%) homens, nos quais se inseriu 2.359 fixações. Destas 1.808 (77\%) localizavam-se na mandíbula e 551 (23\%) na maxila. Depois da segunda fase cirúrgica foram instaladas 393 próteses removiveis e 758 fixas, estas foram reavaliadas anualmente durante 8 anos. Classificou-se os implantes a cada exame: sucesso; falha do implantes com infecção peri-implantar recorrente, ou mobilidade, ou fratura, ou perda óssea progressiva sem sinais de infecção, ou com infecção peri-implantar com supuração necessitando-se de terapia antimicrobiana. A partir desta classificação, cada implante foi classificado como sucesso ou falha de acordo com os cinco critérios citados anteriormente no estudo de BUSER; WEBER; BRÄGGER 44, do ano de 1990. Registrou-se a falha durante a fase de cicatrização de 13 (0.55\%) implantes, durante os 8 anos 19 foram classificados como falha, e no último exame 17 (0.8\%) apresentaram-se com supuração peri-implantar. Incluiu-se 127 (5.4\%) implantes dos pacientes que abandonaram a manutenção e obteve-se a seguinte taxa de sobrevivência e sucesso acumulados nos 8 anos, respectivamente, de $96.7 \%$ e 93.3\%. Como sucesso aplicou-se critérios mais rígidos e os implantes com supuração foram classificados como falha, o percentual dos designados como sobrevivência foi mais alto, devido a flexibilidade dos critérios. A partir da análise dos subgrupos registrou-se índice diferenciado de sucesso para os implantes do tipo parafuso com $>95 \%$ e cilindro-perfurado com 91.3\%; na mandibula foi de 95\% e maxila 87\%. Concluiu-se que os implantes ITI se mantiveram com taxa de sucesso superior a 90\% em diferentes centros clínicos em período de avaliação de 8 anos. 
MOBERG et al. ${ }^{145}$, em 1999, acompanharam 29 pacientes com reconstruções unitárias suportadas por implantes cilindro-perfurado da ITI. Foram inseridas 30 fixações na região de incisivo superior e somente uma destas foi removida com infecção pós-operatória 1 mês após inserção. Realizouse tomadas radiográficas pela técnica do paralelismo dias após instalação da prótese e depois anualmente. Estas foram posteriormente digitalizadas e medidas em programa específico obtendo-se a perda óssea entre duas tomadas radiográficas. Utilizou-se coroas cimentadas em 10 casos e retidas a parafuso em 19 próteses. O índice de sucesso foi de $96.7 \%$ durante período de avaliação de 3 anos e 4 meses. Radiograficamente registrou-se perda óssea de 0.32 na face mesial e 0.19 na distal no primeiro ano, nos anos subsequentes apresentou-se inferior a $0.1 \mathrm{~mm}$ Conclui-se que o sistema de implantes ITI preencheu os requisitos de função e estética.

\subsection{2-IMPLANTES NAPIO}

Os implantes do sistema NAPIO (Núcleo de Apoio à Pesquisa dos Implantes Odontológicos) são confeccionados em titânio grau I comercialmente puro e submetidos a tratamento ácido de superfície após a usinagem. As etapas de confecção dos implantes envolvem usinagem em torno eletrônico, limpeza em ultra-som, remoção das rebarbas de usinagem, jateamento da superficie com jato de esfera de vidro por aproximadamente 1 minuto com aparelho específico para este fim, lavagem em tricloroetileno e álcool absoluto em etapas por 20 minutos no total, condicionamento com ácido sulfúrico a $10 \%$, nova lavagem em etapas, passivação em estufa a $180^{\circ} \mathrm{C}$ durante 30 minutos, armazenamento em ampolas de vidro contendo álcool etílico a $10 \% \mathrm{e}$ esterilização em autoclave. Os implantes do sistema NAPIO apresentam-se sob a forma macroscópica de parafusos com roscas, contendo um orificio apical e sextavado cervical sobre o qual se encaixam os componentes protéticos ${ }^{55}$. A seguir serão apresentados diversos estudos conduzidos sobre o sistema de implantes NAPIO. 
MONCADA $^{149}$, no ano de 1995, em trabalho de tese de doutorado caracterizou as superfícies de $\mathrm{Ti} \mathrm{cp}$ utilizado na fabricação de implantes odontológicos após diferentes tratamentos de superfície. Utilizou-se as seguintes técnicas analíticas da gota séssil, microscopia eletrônica de varredura e espectroscopia de elétrons Auger. Através destas permitiu-se análise das propriedades superficiais da camada de óxidos e das alterações superficiais frente a diferentes tratamentos. Para tanto, noventa discos de titânio comercialmente puro foram preparados metalograficamente, polidos e submetidos a protocolo de limpeza através de solventes e lavagens com água bidestilada e deionizadas. Através do jateamento das superficies polidas foram obtidas duas texturas superficiais: superficie a- jateadas com esfera de vidro de $25 \mu \mathrm{m}$ e b- jateadas com partículas de óxido de alumínio de $50 \mu \mathrm{m}$, sendo cada grupo subdividido em outros 3 grupos recebendo diferentes tratamentos ácidos de superficie:

- solução de ácido sulfúrico a $10 \%$ durante 20 minutos;

- solução de ácido nítrico a 30\% e fluorídrico a 3\% na proporção de 10:1 durante 20 minutos

- solução de ácido sulfúrico a $10 \%$ durante 20 minutos, lavagem em água bidestilada e tratamento com solução de ácido nítrico 30\% e ácido fluorídrico 3\% na proporção de 10:1 durante 20 minutos.

Todas as amostras foram lavadas ultra-sônicamente 3 vezes em água bidestilada deionizada e secas à temperatura ambiente nos respectivos tubos de vidro. Posteriormente, foram passivadas em estufa e esterilizadas em ampolas fechadas contendo álcool etílico a 10\% através de autoclavagem. Obteve-se os resultados através da mensuração dos ângulos de contato e avaliação estatística por análise de variância, Mann-Whitney $\mathrm{U}$, teste-t e Bonferroni teste-t. Concluiu-se que os ângulos de contato foram significantemente menores em ambas as superficies a e b tratadas com ácido sulfúrico, e significantemente reduzidas para o grupo b após esterilização. $\mathrm{Na}$ análise em microscopia eletrônica de varredura indicou-se que a morfologia superficial foi diferente entre as superfícies a e b, demonstrando a presença de partículas provavelmente resultantes do processo de jateamento. As superficies a e b tratadas com ácido sulfúrico não se mostraram com alterações significativas na morfologia original. Na análise pela espectroscopia de elétrons 
Auger detectou-se presença de titânio, oxigênio e carbono como elementos dominantes em todas as amostras não esterilizadas e diminuição destes após a esterilização, associado à presença de alumínio, silício e cálcio, este em menor proporção.

No mesmo ano, MEIRA ${ }^{142}$, apresentou em dissertação de mestrado, a porcentagem de superfície osseointegrada e densidade óssea no interior das 3 primeiras roscas. A partir da cortical analisou-se comparativamente entre implantes tratados superficialmente com ácido sulfúrico a $10 \%$ e jateamento com óxido de titânio. Para tanto, foram inseridos 40 implantes de titânio na metáfise tibial de 20 coelhos brancos adultos de ambos os sexos, divididos em dois grupos de acordo com o tratamento de superficie. Cada animal recebeu dois implantes, sendo um utilizado para análise histológica e outro em testes de remoção ao torque. A análise histológica revelou maior média de superficie osseointegrada, porcentagem de contato, para o grupo tratado por ácido com $92.5 \%$, do que o grupo tratado com óxido de titânio com $87.4 \%$, enquanto que as densidades ósseas médias dentro das roscas foram, respectivamente, de 67.034 e 52.724. Quanto às medidas de remoção ao torque, os seguintes resultados foram obtidos: $92,513 \mathrm{Ncm}$ e $87,430 \mathrm{Ncm}$ para os grupos tratados com ácido e óxido de titânio, respectivamente. Os resultados das análises histológicas e teste de remoção ao torque indicam maior porcentagem de contato, densidade óssea e força de remoção ao torque para implantes tratados superficialmente com ácido sulfúrico a $10 \%$.

De acordo com ARAGONES ${ }^{21}$, no ano de 1996, é imperativo na pesquisa básica de implantes a definição da superfície de implantes metálicos compativeis com resposta óssea apropriada, especialmente em busca de soluções para áreas de baixa densidade óssea. Diferentes tratamentos superficiais foram avaliados em 28 coelhos albinos machos. Cada animal recebeu 2 implantes de titânio grau I tratados através de:

Grupo I- limpeza com detergente;

Grupo II- limpeza com detergente, seguido de tratamento com ácido sulfúrico a $10 \%$ 
Grupo III- limpeza com detergente, tratamento com ácido sulfúrico 10\% e jateamento com óxido de alumínio

Grupo IV- limpeza inicial e passivação com ácido nítrico

Destinou-se um implante para avaliação histológica e outro a teste de remoção ao torque. Os animais foram sacrificados 12 semanas após a instalação dos implantes. Após confecção das lâminas, as imagens foram analisadas com processador de imagens digitalizadas, através da mensuração da porcentagem de contato linear entre osso e implante nas 2 primeiras e 2 últimas roscas de cada implante Os valores de porcentagem de osseointegração foram significativamente mais elevados para o grupo II foi de 58.28\% e IV com $51.59 \%$, através de análise estatística por métodos não-paramétricos. Nos resultados de remoção ao torque demonstrou-se maior média de força de remoção ao torque para o grupo III foi de $147,2 \mathrm{Ncm}$, tendo este grupo apresentado maior média de densidade óssea no interior das roscas com 76,467. Estes resultados foram estatisticamente diferentes do grupo II com 85.286 Ncm e 68.781 de densidade óssea. A medida de densidade óssea se encontra diretamente relacionada com o teste de remoção ao torque mas não apresentou-se com relação direta à superficie osseointegrada.

No ano de 1996, ROCHA 173 , avaliou os diferentes tratamentos da superficie dos implantes de titânio grau I, foram os seguintes:

- tratamento superficial com ácido sulfúrico a $10 \%$

- tratamento superficial com ácido nítrico 30\% e ácido fluorídrico 3\%, seguido de ácido sulfúrico a $10 \%$

- tratamento superficial com ácido nítrico a 30\% e ácido fluorídrico a 3\%

- ausência de tratamento 
Para se proceder esta avaliação foram inseridos discos de titânio tratados da forma descrita acima em 12 coelhos albinos machos, sendo que cada animal recebeu duas amostras. Um dos discos foi examinado em microscópio de força atômica para avaliação da rugosidade superficial provocada pelo tratamento químico, complementando os resultados obtidos nos trabalhos anteriores. Após 8 semanas de cicatrização, os animais foram sacrificados e as peças removidas para análise histológica realizada com auxílio de processador de imagens digitalizadas, onde foi avaliado o crescimento ósseo linear entre o osso e a superficie dos discos. Os resultados obtidos demonstraram superioridade dos grupos tratados com métodos que aumentam a rugosidade superficial, sendo que os valores de osseointegração mensurados em percentual de contato foram mais elevados para os grupos que associam o tratamento com três substâncias ácidas foi de 308.4 e com ácido nítrico mais ácido fluorídrico de 299.3, enquanto os grupos tratados com ácido sulfúrico e sem tratamento apresentaram indices de 128.2 e 143.9 , respectivamente. Esses resultados mostraram-se diretamente relacionados à rugosidade superficial dos discos de titânio, após o tratamento químico.

No ano de 1996, CORREIA55, avaliou os implantes do sistema NAPIO quanto à taxa de sobrevivência a curto prazo. Foram avaliados 100 pacientes nos quais foram inseridos, consecutivamente, 449 implantes do sistema NAPIO, com superficie tratada por ataque ácido. Os implantes foram avaliados de acordo com o critério de imobilidade clínica manualmente verificada durante a $2^{\mathrm{a}}$ cirurgia. Os resultados obtidos indicaram $98.23 \%$ e $100 \%$ de sobrevivência até a $2^{\mathrm{a}}$ fase cirúrgica, respectivamente, para maxila e mandíbula. Os indices de sobrevivência obtidos neste trabalho de pesquisa se apresentaram elevados e compativeis com relatos de literatura, atestando a efetividade clínica a curto prazo do sistema de implantes avaliado. As perdas se concentraram na região posterior de maxila, correspondendo a $75 \%$ destas e ressaltou-se a influência da qualidade do tecido ósseo no prognóstico dos implantes. Poucas complicações foram registradas, sendo que a maioria consistiu em exposição da tampa de recobrimento. Nenhuma das complicações encontradas se correlacionou com a perda do implante. 
No ano de 1997, SPERANDIO ${ }^{188}$, em tese de doutorado avaliou a possibilidade de reaproveitamento de brocas de aço inoxidável durante o preparo de leitos ósseos para implantação de parafusos de Ti cp. Objetivou-se testar em modelos experimentais quanto à integridade da interface osso-metal. Para avaliar se a quantidade de calor friccional gerado na interface broca-osso influenciava o comportamento ósseo foram utilizados 15 coelhos machos albinos. Nestes instalou-se 2 implantes usinados com titânio grau I e tratamento de superfície com ácido sulfúrico a $10 \%$ após tratamento básico. Um dos implantes foi utilizado para análise histológica de porcentagem de osseointegração na interface osso-metal e densidade óssea no interior das roscas. O segundo implante foi utilizado em teste mecânico da resistência da interface osso-metal, ou seja, teste de remoção ao torque. Os animais foram divididos em 3 grupos de acordo com as condições de uso da broca. No grupo I incluiu-se os animais que tiveram as perfurações preparadas com brocas novas, grupo II por brocas com 5 usos e grupo III por brocas com 10 usos. As perfurações foram confeccionadas inicialmente com broca esférica, acompanhada por cilindrica de $3 \mathrm{~mm}$. Durante o período de cicatrização de 6 semanas, foram administrados endo-venosamente marcadores ósseos fluorescentes a tetraciclina e calceína da segunda à quinta semana. Ao final deste período, os animais foram sacrificados e as peças preparadas para análise histológica em material não descalcificado. Nos resultados obtidos demonstrou-se não haver diferenças estatisticamente significantes com reutilização de brocas. Obteve-se os seguintes resultados frente aos parâmetros de percentual de osseointegração para os grupos I, II e III de respectivamente 31.234, 28.459 e 52.975 e densidade óssea intra-rosca de 78.265, 81.189 e 77.650 para os grupos I, II e II respectivamente. Em relação ao teste de remoção ao torque registrou-se os seguintes valores para os grupos I, II e III, respectivamente, $25.980, .32 .100$ e $26.220 \mathrm{Ncm}$. 
No ano de 1997, MAGINI136, em tese de doutorado avaliou se a energia de superficie poderia influenciar o povoamento celular inicial e adesão de células sobre a superfície do implante em contato com o fluido biológico. A partir do pressuposto que a tensão superficial pode ser metodologicamente melhorada, neste estudo foi analisada a influência dos métodos de armazenagem dos implantes na porcentagem de osseointegração e em testes de remoção ao torque. Para tanto, foram utilizados 12 coelhos machos albinos que receberam 2 implantes na tíbia, sendo 1 estocado no detergente lauril a $2 \%$ e outro estocado em álcool etílico a 10\%. Após 4 meses, os animais foram sacrificados e as peças removidas de sete animais foram analisados histologicamente com auxílio de processador para imagens digitalizadas e 5 coelhos foram submetidos ao teste de remoção ao torque. Os resultados obtidos demonstraram que os implantes armazenados em álcool etílico a 10\% apresentaram porcentagem de osseointegração estatisticamente mais elevadas do que os implantes armazenados em lauril, embora os resultados obtidos com os testes de remoção ao torque não apresentem diferenças estatisticamente significantes.

O tratamento de pacientes desdentados totais ou parciais se tornou, com o surgimento dos implantes osseointegrados, opção viável e com prognóstico previsível. Após a perda do elemento dental, entretanto, o rebordo alveolar sofre processo de reabsorção progressivo que pode ou não ser acentuado por fatores externos. Assim, apesar dos altos índices de sucesso obtidos, parte da população não poderia ser submetida a este tipo de tratamento por apresentarem deficiência de estrutura óssea adequada à colocação dos implantes. Assim, diversas técnicas de reconstrução de rebordos severamente reabsorvidos tem sido propostas com o objetivo de possibilitar aos pacientes o tratamento através de implantes osseointegrados. SANT'ANA178, apresentou em 1997, os dados do tratamento de 50 pacientes com idade variável entre 13 e 68 anos, através das técnicas de enxerto ósseo dos tipos: 
- Mandíbula:

- Onlay com implantes imediatos;

- Onlay com implantes tardios;

- Maxila:

- Onlay com implantes imediatos;

- Onlay com implantes tardios;

- Inlay com Le Fort I;

- Inlay sem Le Fort I (levantamento de seio maxilar);

- Combinado inlay-onlay,

As áreas doadoras selecionadas foram: crista anterior do iliaco, mento, tíbia e área retromolar de mandíbula. Os pacientes foram avaliados quanto: (1) a mobilidade clínica dos implantes; (2) presença de zona radiolúcida entre tecido ósseo e implante em radiografias; (3) à sintomatologia dolorosa das áreas doadoras e receptoras; (4) à existência de complicações pós-operatórias e (5) à sobrevivência a curto prazo dos implantes inseridos, de acordo com os critérios definidos nos itens 1, 2 e 3, este relativamente ao leito receptor. Nos resultados obtidos indicou-se que a técnica onlay com implantes tardios apresentou-se com o mais alto índice de sobrevivência com100\%, acompanhado pelas técnicas inlay sem Le Fort com 92\%, inlay com Le Fort com $86.7 \%$ e onlay com implantes imediatos com $60 \%$. Os implantes do sistema NAPIO apresentaram-se com taxa de sucesso de $86.7 \%$, sendo 12 perdidos dos 95 inseridos para os pacientes do grupo I, avaliados até 1 ano após a conexão das próteses, e $92.1 \%$ com 8 perdidos em 110 inseridos para os pacientes do grupo II, avaliados até a $2^{\mathrm{a}}$ fase cirúrgica. Os resultados apresentavam-se compativeis com os dados encontrados na literatura. 


\section{3-PROPOSIÇÃO}

A proposta deste trabalho consiste na avaliação do sucesso, e manutenção das próteses suportadas por 371 implantes osseointegrados do sistema NAPIO em 109 pacientes, durante 2 anos. Com este objetivo foram analisados os seguintes aspectos:

1. classificação dos implantes como sucesso, sobrevivência, falha e não computado, de acordo com a tabela de quatro campos de ALBREKTSSON; ZARB ${ }^{13}$, em 1993;

2. monitoramento das próteses quanto a ocorrência de quaisquer complicações, como por exemplo, fratura do parafuso do intermediário, solucionando-as;

3. questionamento dos pacientes quanto a satisfação com o tratamento aferindo notas de 0 a 10, em relação a estética, fonética e função;

4. utilização de parâmetros usuais no monitoramento periodontal (profundidade de sondagem, nível de inserção, presença de placa, sangramento, vermelhidão, edema e supuração) em cada implante, com intenção de se acompanhar a saúde do tecido mole peri-implantar;

5. realização de tomadas radiográficas pela técnica do paralelismo, com posicionadores individualizados para cada área, pelo registro da mordida em resina acrílica tipo Duralay. Estas foram digitalizadas e mensurou-se em programa específico a perda óssea nos 2 anos;

Os dados obtidos deveriam preencher os critérios de sucesso dos sistemas de implantes osseointegrados, propostos por SMITH; ZARB' ${ }^{186}$, no ano de 1989. 


\section{4-MATERIAL E MÉTODOS 4.1-MATERIAL}

Os pacientes foram examinados depois da instalação de próteses suportadas por implantes. Foram atendidos 109 pacientes no primeiro exame imediatamente após a instalação da prótese, no segundo exame realizado depois de 6 meses foram examinados 103 pacientes, no terceiro com 1 ano foram atendidos 99 e no quarto com 2 anos 89 pacientes. Estes dados encontram-se dispostos no quadro $n^{\circ}$. 1 . Os pacientes da tese foram atendidos inicialmente no final de fevereiro de 1997 e continuaram a ser examinados e incluídos como primeiro exame até junho de 1997. O segundo exame dos pacientes examinados em fevereiro começou como proposto anteriormente em agosto, seis meses após o primeiro. Os atendidos em março se iniciou em setembro, e assim por diante: abril-outubro; maio-novembro e junho-dezembro. O terceiro exame se realizou exatamente um ano após o começo da pesquisa, iniciando-se em fevereiro de 1998 e finalizando-se em junho do mesmo ano. O quarto exame foi realizado de forma condensada em abril, maio e junho, sendo que alguns retardatários no mês de julho de 1999, finalizando 2 anos de acompanhamento.

Tabela $\mathbf{n}^{\circ}$ 5: Apresentação do número de pacientes e implantes avaliados nos quatro exames.

\begin{tabular}{|l|l|l|l|l|}
\cline { 3 - 5 } \multicolumn{2}{c}{} & \multicolumn{3}{l|}{ Número de implantes } \\
\cline { 2 - 5 } & $\mathbf{N}^{\circ}$. de pacientes & Maxila & Mandibula & Total \\
\hline $\mathbf{1}^{\circ}$ exame & $109(100 \%)$ & 106 & 265 & 371 \\
\hline $\mathbf{2}^{\circ}$ exame & $103(94.49 \%)$ & 99 & 253 & 352 \\
\hline $\mathbf{3}^{\circ}$ exame & $99(90.82 \%)$ & 92 & 234 & 326 \\
\hline $\mathbf{4}^{\circ}$ exame & $89(81.65 \%)$ & 92 & 219 & 311 \\
\hline
\end{tabular}




\section{2-MÉTODOS}

As cirurgias de inserção das fixações foram realizadas no NAPIO (Núcleo de Apoio a Pesquisa em Implantes Odontológicos) localizado na Faculdade de Odontologia e a confecção das próteses na unidade deste localizada fora da Faculdade, na Avenida Getúlio Vargas. O acompanhamento dos pacientes foi realizado neste último denominado de NAPIO de prótese, devido à disponibilidade de componentes protéticos em estoque se fosse necessária substituição de qualquer um destes.

Os pacientes atendidos no NAPIO possuem pastas individuais devidamente numeradas e arquivadas de forma ordenada. Nestas estão incluídas diversas fichas detalhadas, em relação à anamnese, planejamento, exames complementares e procedimentos clínicos realizados. Além destas, foi incluída a ficha de manutenção idealizada para a realização deste trabalho e esta está incluída no final da tese no item Apêndice 1. Os itens desta ficha serão descritos em detalhes a seguir.

Inicialmente foram questionados os dados pessoais do paciente, apesar destes estarem relacionados de forma completa na ficha inicial. Foram relatados: nome, sexo, idade, endereço e telefone. Foi registrada a data da instalação da prótese e do atendimento, e grifava-se se a arcada examinada era inferior ou superior.

Os pacientes foram divididos em fumantes e não fumantes na tentativa de se estabelecer possivel correlação entre este hábito e a ocorrência de falhas. Foi questionado também quantos cigarros o paciente fumava ao dia. A investigação sobre o tabagismo se fundamentou no trabalho de BAIN; MOY ${ }^{32}$ do ano de 1992, no qual detectou-se concentração das perdas dos implantes em todas as regiões da boca de pacientes fumantes, exceto a porção posterior da mandíbula. 
Em seguida, os pacientes foram questionados quanto à realização de enxerto ósseo ou se havia sido submetido a radioterapia previamente a inserção da fixação.

A seguir, os implantes foram relacionados de acordo com a tabela de quatro campos proposta por ALBREKTSSON; ZARB ${ }^{13}$, do ano de 1993. Sendo subdivididos em: Sucesso (Ss), Sobrevivência (S1), Não computado (U) e Falhas (F), como descrito abaixo:

-Sucesso (Ss), aplicado aos casos devidamente testados em relação à imobilidade clínica testada entre dois instrumentos depois da remoção da prótese, ausência de radioluscidez peri-implantar e preenchendo os critérios de sucesso de SMITH, ZARB ${ }^{186}$, do ano de 1989;

-Sobrevivência (S1), para os implantes que permanecessem em função, contudo sem mencionar avaliação clínica, ou radiográfica ou critérios de sucesso definidos; -Não computado (U), para aqueles que não comparecessem aos retornos por qualquer motivo;

-Falha $(F)$, aplicados aos que fossem removidos independentemente do motivo da falha ou remoção, ou permanecessem adormecidos.

No espaço em branco abaixo da tabela de quatro campos foram anotados todos os dados e datas relativos as duas fases cirúrgicas. Estes dados foram obtidos da ficha do NAPIO, sendo que em todos os exames esta era requisitada na Faculdade. Este cuidado foi mantido, pois a ficha deveria estar disponivel se houvesse necessidade de complementação de quaisquer dados do paciente. Como também, foi registrada a data da consulta de manutenção e todos os procedimentos realizados no paciente, mantendo a ficha do NAPIO sempre atualizada.

Seqüencialmente, realizou-se a avaliação da prótese propriamente dita. Foi observado primeiramente o tipo de prótese sobre implante: protocolo, sobre-dentadura, parcial (1, 2, 3 ou 4 elementos) conectada ou não aos dentes remanescentes e unitária. Foi relatado o tipo de antagonista presente: dente 
natural; prótese total, fixa ou removivel convencional; ou suportada por implante. A prótese sobre implante foi avaliada, em relação à presença ou ausência de diversas complicações:

- fratura da infra-estrutura, parafuso da prótese ou do intermediário, clipe da sobre-dentadura, ou outros;

- mobilidade da prótese quando submetida à pressão manual na porção distal;

- dificuldade na fonação;

- presença de sintomatologia dolorosa peri-implantar;

- parestesia por comprometimento da inervação durante o ato cirúrgico para instalação da fixação;

- desconforto muscular, após instalação da prótese;

- sintomatologia dolorosa na ATM e

- necessidade de reembasamento da prótese.

- presença de desgaste da porcelana foi observada por índice de 0 a 3 proposto por LINDQUIST; CARLSSON; GLANTZ ${ }^{132}$, no ano de 1987. Os índices possuíam os seguintes significados: 0-desgaste não visível; 1-desgaste único na faceta; 2desgaste marcante na faceta; 3-desgaste extremo com destruição da morfologia oclusal.

- o paciente aferiu notas de 0 a 10 para os seguintes aspectos: função, estética e conforto. Estes critérios abordados se basearam no trabalho de SMEDBERG e colaboradores $^{185}$, do ano de 1991.

Após a avaliação das características da prótese, procedeu-se a remoção desta. Inicialmente grifava-se na ficha qual a arcada a ser avaliada e no caso do paciente possuir mais do que 6 implantes na boca incorporava-se mais uma folha de índices à ficha. Todos os implantes conectados a prótese ou adormecidos foram registrados. Os implantes foram localizados através da correlação entre a posição na arcada o mais aproximado possível, com o correspondente ao sistema numérico empregado às unidades dentárias. Por exemplo, um implante localizado na região do incisivo central superior direito será 
registrado no parênteses como 11. Para cada implante monitorou-se os seguintes indices clínicos usais no diagnóstico da doença periodontal:

- profundidade de sondagem;

- nível de inserção;

- sangramento à sondagem;

- edema;

- coloração;

- mobilidade;

- supuração.

Foi mensurada em 6 faces de cada implante profundidade de sondagem, distância do topo do intermediário até a margem gengival, nível de inserção, e presença de placa bacteriana. Na primeira linha os dados das 3 faces vestibulares e na segunda os das linguais. Profundidade de sondagem, distância entre o topo do intermediário à margem gengival e nível de inserção foram registrados com sonda periodontal plástica (Premier, Perio Wise) apresentada na figura 1 e na 2 com a sonda penetrando no sulco peri-implantar. Sendo que a primeira marca verde da sonda corresponde até 3 milímetros, a linha vermelha fina a $5 \mathrm{~mm}$ e a última vermelha 7 a $10 \mathrm{~mm}$. A profundidade de sondagem representou a penetração da sonda desde a margem gengival até o fundo do sulco ou bolsa peri-implantar. O valor da distância do topo do intermediário até a margem gengival foi registrada com a mesma sonda. Foram somados os valores da profundidade de sondagem e da distância do topo do intermediário até a margem gengival obtendo-se o nivel de inserção nos implantes. Em seguida, coletou-se os dados pertinentes a presença de placa bacteriana em 6 faces da cada implante. Os demais índices, sangramento a sondagem, edema, coloração, mobilidade e supuração foram registrados por valores dicotômicos ( $\operatorname{sim} /$ não=presença/ ausência) sendo considerado positivo se fosse presente em qualquer uma das faces vestibulares ou linguais. 


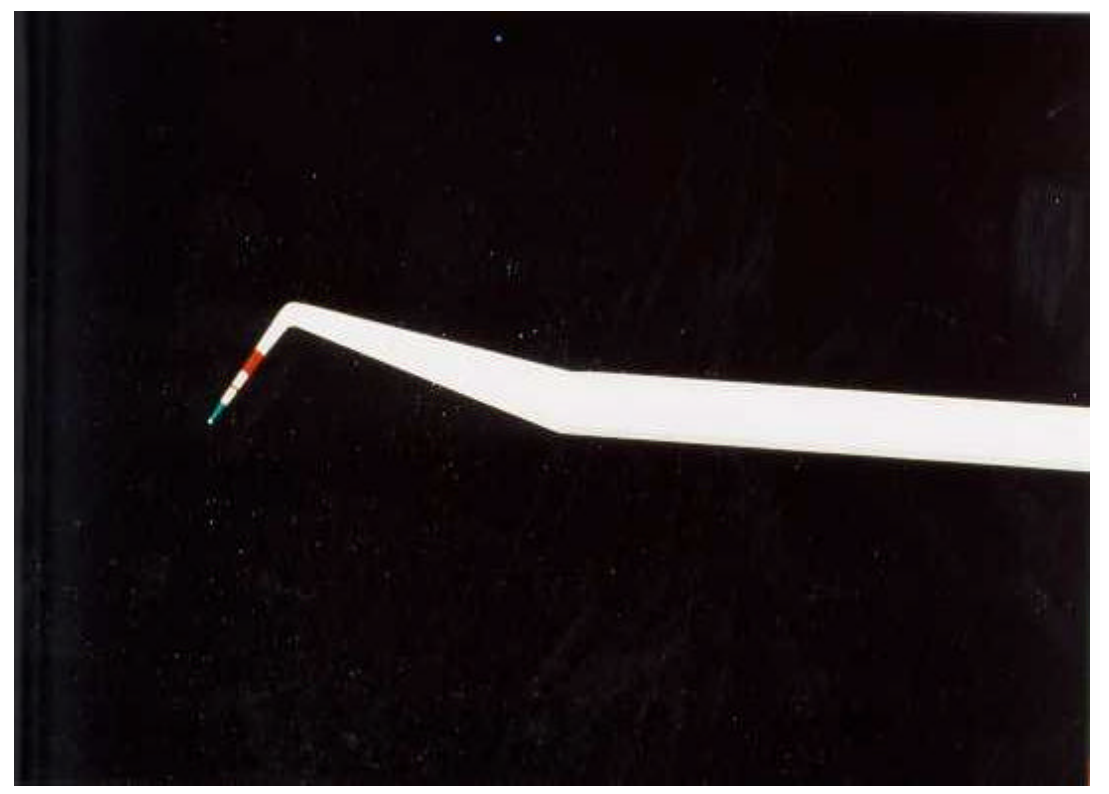

Figura 1-Sonda plástica (Premier, Perio Wise) utilizada para sondagem de sulco peri-implantar. 


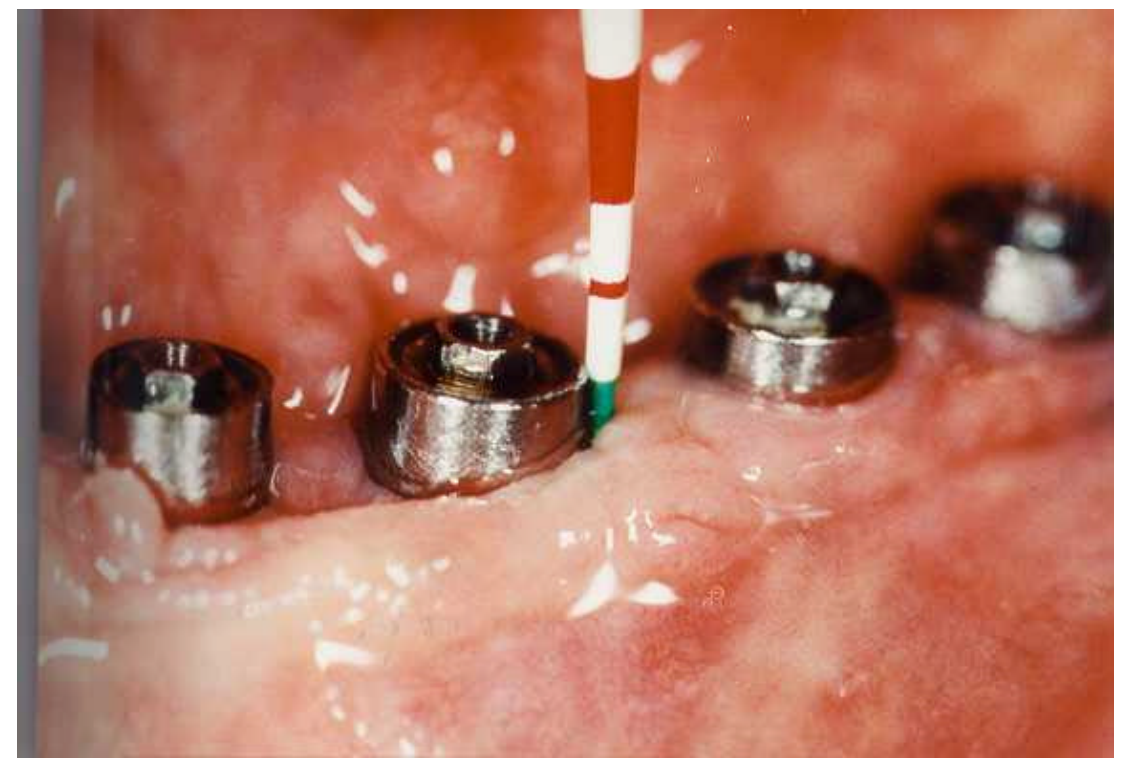

Figura 2-Medição da profundidade de sondagem do sulco peri-implantar. 
O controle radiográfico foi padronizado com radiografias periapicais pela técnica do cone longo e processamento automático das radiografias em máquina (Peri-pro) uniformizando o padrão do contraste. Inicialmente a área da prótese foi devidamente vaselinada para a resina não aderir à prótese. Em seguida, para cada paciente foi confeccionado registro da mordida habitual na área da prótese sobre implante em resina tipo Duralay da cor vermelha, sobre uma replica previamente confeccionada em resina do posicionador intra-bucal, apresentado na figura 3. Este foi adaptado em dispositivo específico para a técnica do paralelismo direcionando o feixe do raio-x paralelamente ao filme. Utilizou-se filmes periapicais infantis para a área anterior e convencionais para os dentes posteriores. O aparelho de raio-x possuía $70 \mathrm{KVp}$ de potência e o tempo de exposição dos filmes foi padronizado em 0.6 e 0.8 segundos, respectivamente, para a maxila e mandíbula. $\mathrm{O}$ aparato utilizado para radiografia periapical pelo cone longo com posicionador individualizado se apresenta na figura 4, 5 e 6 . Os posicionadores foram armazenados em pote plástico com tampa, individualizado através de etiqueta auto-colante com o nome e número de registro do paciente no NAPIO. Nos primeiros seis meses os posicionadores foram completamente imersos em água, a fim de evitar-se distorções. Foi adicionada na água de cada pote uma colher de sopa de hipoclorito, para se evitar a proliferação de microorganismos e algas. No segundo exame a água foi removida e os posicionadores continuaram acondicionados nestes potes individualizados. Os potes foram cuidadosamente armazenados entre os exames e foi utilizado o posicionador todas as vezes que foi realizada nova tomada radiográfica. 


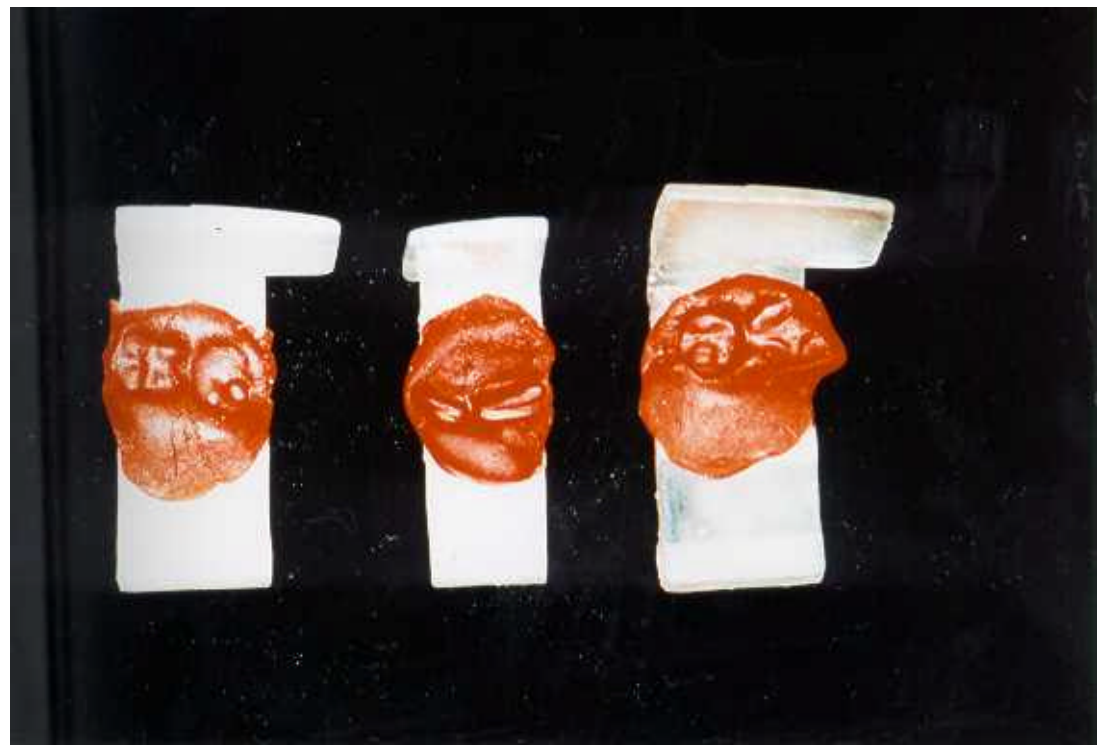

Figura 3-Posicionadores individualizados por registro da mordida em resina. Os dois dos extremos para área posterior e o do centro para região anterior. 


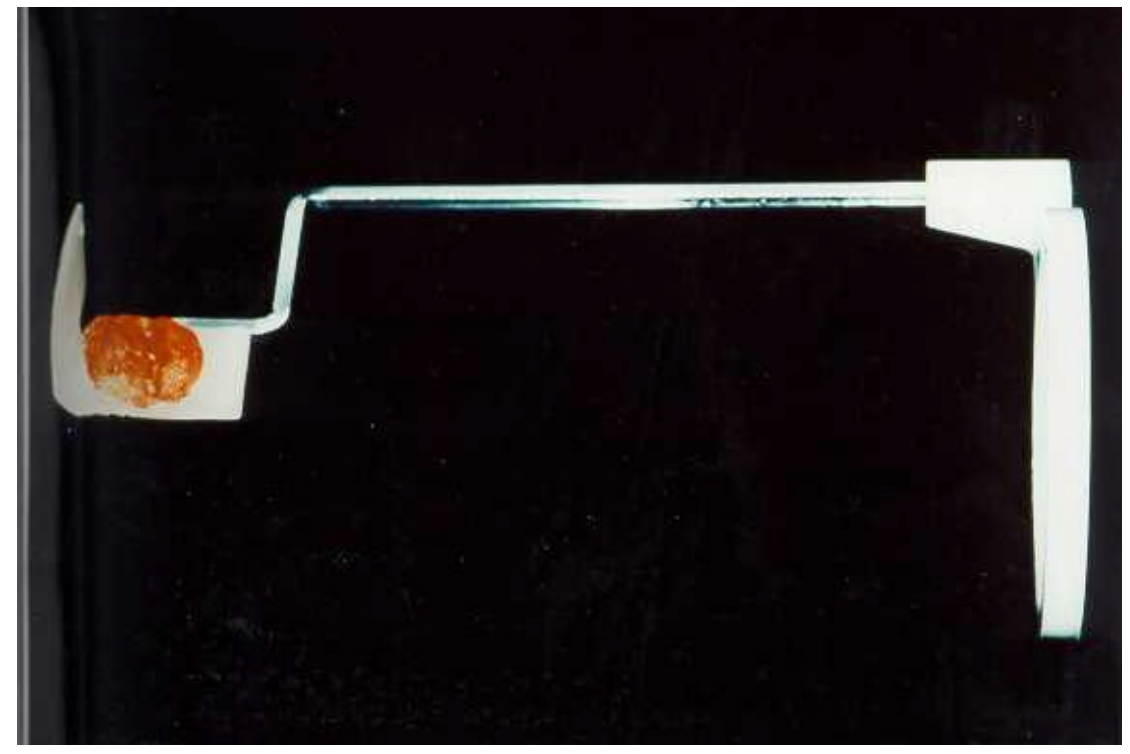

Figura 4-Posicionador individualizado encaixado no suporte especifico para a técnica do paralelismo. 


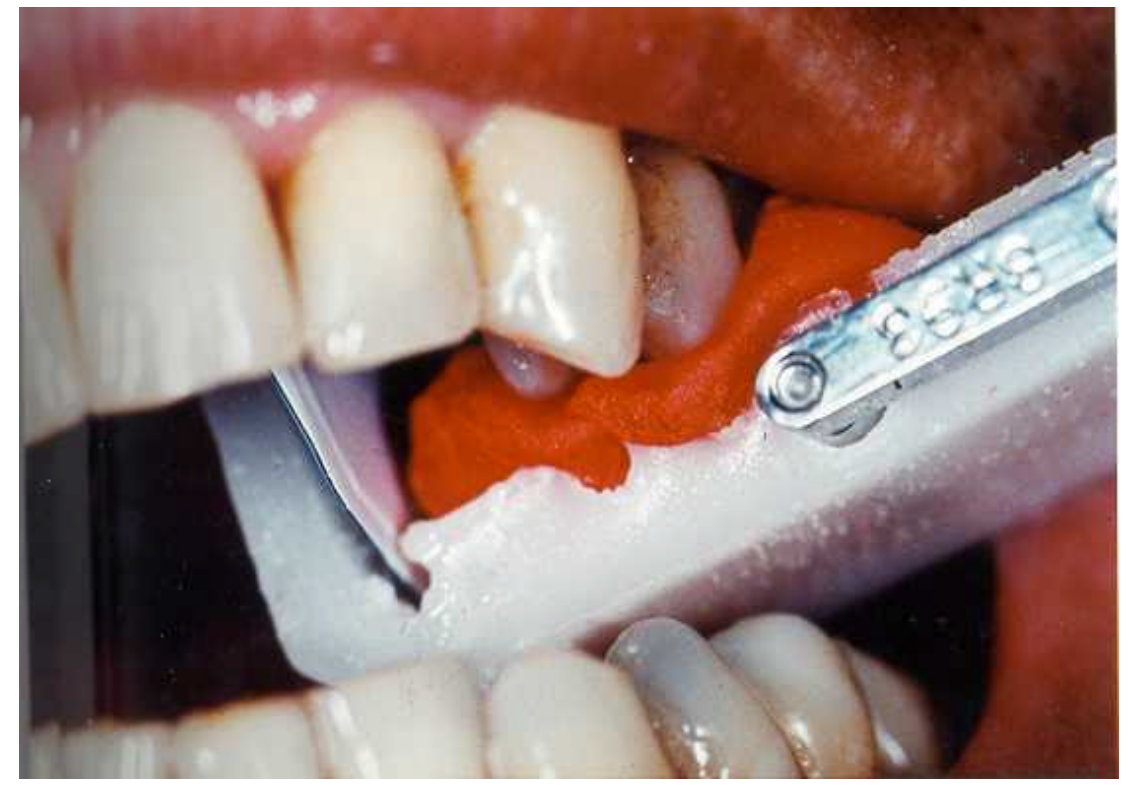

Figura 5-Vista intra-bucal do posicionador individualizado com mordida em resina. 


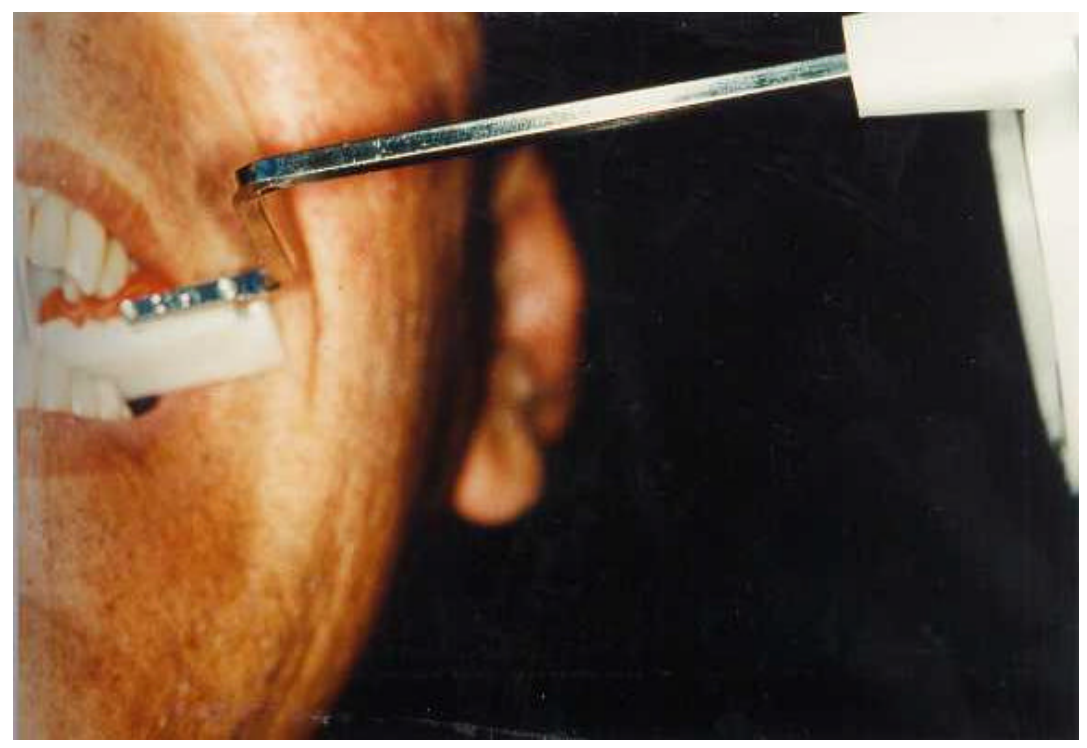

Figura 6-Aparato para radiografia periapical pela técnica do paralelismo com o posicionador individualizado. 
Os procedimentos clínicos realizados em cada sessão foram devidamente registrados no item 6. Todos os pacientes foram devidamente instruídos quanto a higiene bucal, sendo utilizado fio dental com passa fio ou previamente montado (Superfloss) ou gaze cuidadosamente cortada e passada entre o intermediários, como também escova convencional associada a interdental ou bitufo. Durante os dois anos de acompanhamento, os pacientes foram cuidadosamente monitorados quanto à higiene bucal estabelecendo-se a associação individualizada dos instrumentos mais efetivos. Em alguns casos, os intermediários e as próteses apresentavam-se com cálculo em algumas faces, sendo necessária a limpeza com curetas plásticas. Este procedimento se apresenta ilustrado na figura 7. Em alguns pacientes, necessitou-se resolver problemas diagnosticados durante as consultas de manutenção. Ao se detectar complicações e se estas fossem passíveis de resolução imediata, como por exemplo troca de parafusos fraturados da prótese (representado na figura $n^{\circ} 8$ ) ou do intermediário (apresentado na figura $\mathrm{n}^{\circ}$ 9), estas eram imediatamente realizadas. Se fosse alguma complicação de resolução mais demorada solicitavase outro horário para efetuar os procedimentos necessários. Entretanto, inevitavelmente em alguns casos a solução foi obrigatoriamente imediata e necessitou-se remarcar os outros pacientes priorizando a solução do problema.

Ao final ratificava-se qualquer alteração quanto a classificação do implante na tabela de quatro campos proposta por ALBREKTSSON; ZARB ${ }^{13}$, no ano de 1993, se houvesse detecção de alterações neste. 


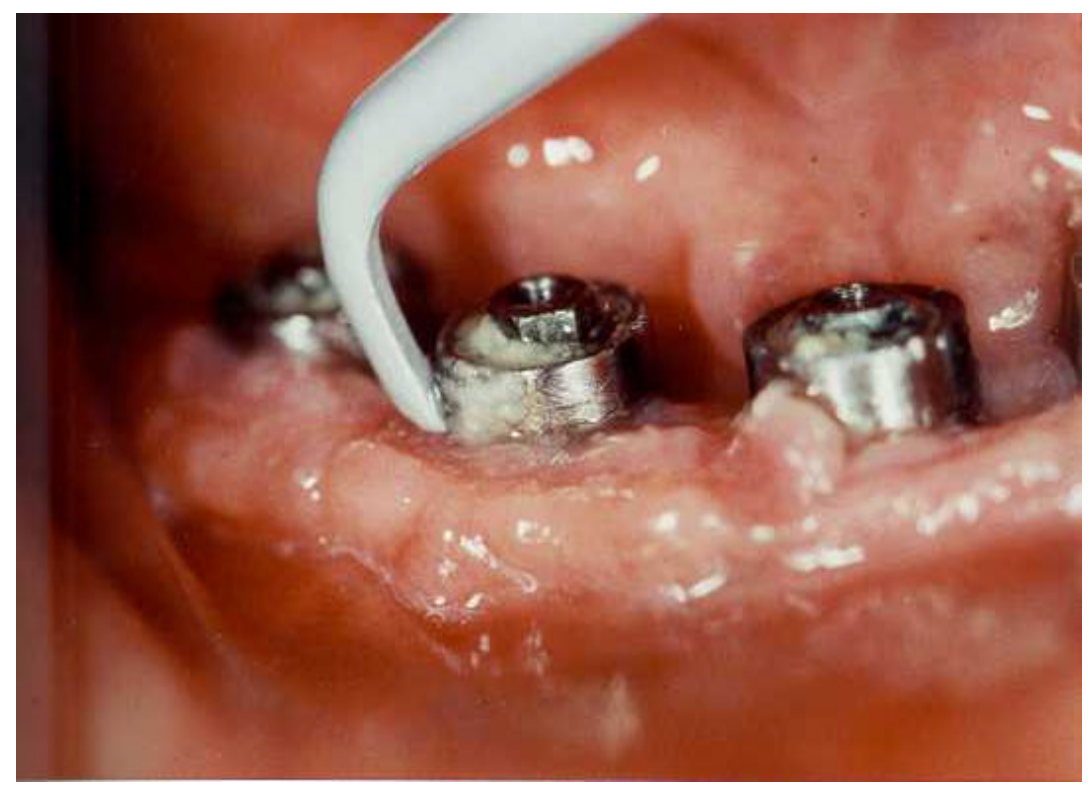

Figura 7-Limpeza da superfície do implante com cureta plástica (ImplantProphy+). 


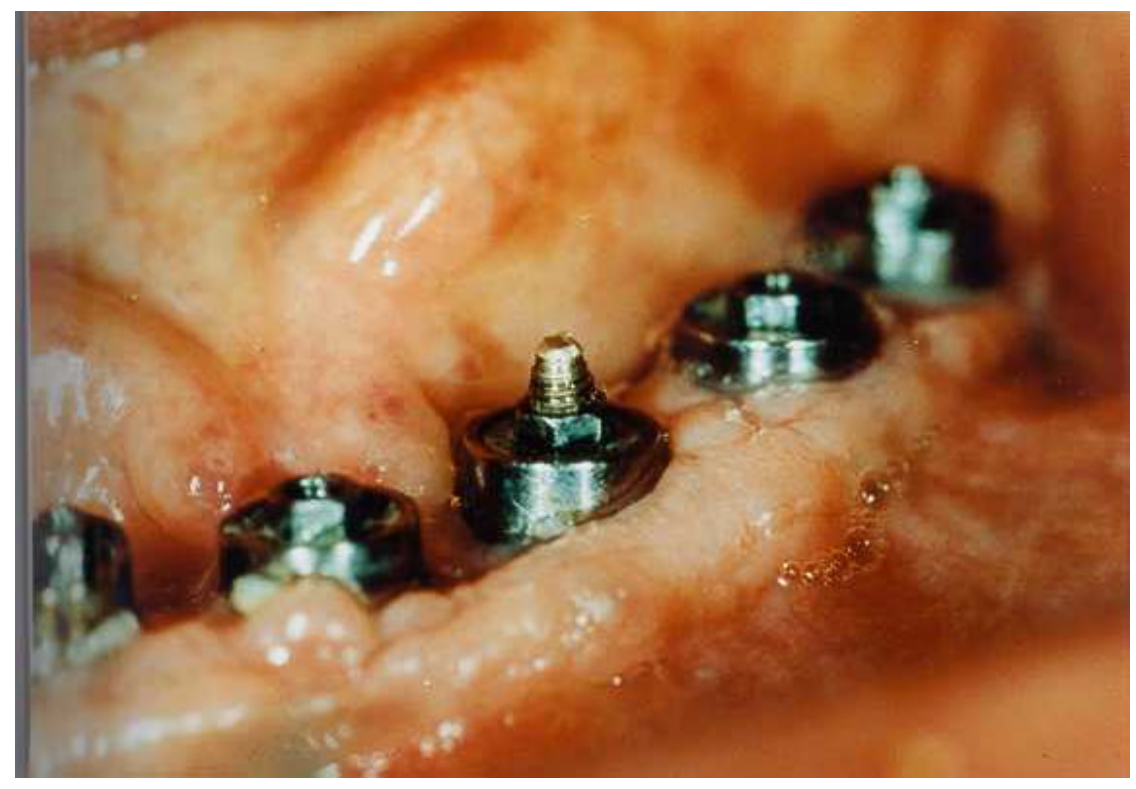

Figura 8-Fratura do parafuso da prótese. 


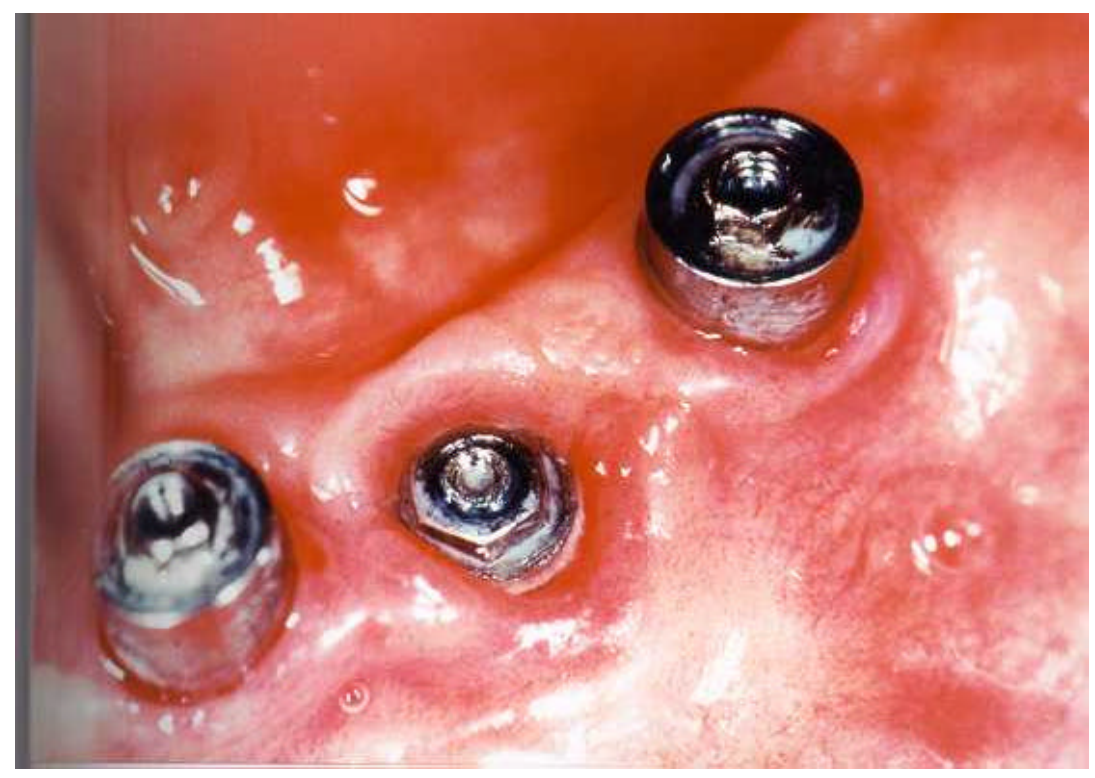

Figura 9- Fratura do parafuso do intermediário. 


\subsection{ANÁLISE DOS DADOS}

As radiografias foram sendo progressivamente digitalizadas através de scanner próprio para slide $35 \mathrm{~mm}$ denominado Sprintscan 35 (Polaroid). Todas as radiografias foram digitalizadas e gravadas no formato BMP. As imagens digitalizadas obtidas foram gravadas em $\mathrm{CD}$ room e analisados por programa específico Sigma Scan Pro 4 (Mocha Image Analyses, Jandel Scientifcs). Os dados foram transportados imediatamente para uma tabela registando-se os dados de cada paciente. Na primeira coluna registrava-se o número do exame e do paciente através de códigos. Estes foram identificados por números e letras, como A1 a A8, e daí por diante, todas as letras até o número 8 e a última letra foi N4. Quando os dados se referiam ao primeiro exame colocava-se o algarismo 1 na frente, sendo $1 \mathrm{~A} 1$, se fosse o segundo $2 \mathrm{~A} 1$ e dai em diante. Se os pacientes tivessem mais de 3 implantes dividia-se em duas linhas colocando no final da sigla a letra "a", depois "b", e se necessário "c". Deste modo obteve-se siglas para cada exame, identificando os pacientes de forma compreensivel e sucinta durante a análise dos dados radiográficos e clínicos. As siglas e o primeiro nome dos 109 pacientes se encontram anexados no apêndice 2. Em seguida, as três primeiras colunas referiam-se às medidas reais em mm de cada fixação, já que no máximo foram incluídos 3 implantes por radiografia. Depois em outras três colunas, registrou-se as medidas efetuadas através de linhas traçadas com o mouse desde o topo do implante até o ápice deste, e o programa apresentava esta medida em mm. Estas medidas foram realizadas para avaliar a distorção da radiografia através da comparação entre tamanho real registrado nas três primeiras colunas com os da quarta, quinta e sexta coluna obtidos nas radiografias mensuradas pelo programa. Depois efetuou-se medidas nas faces mesiais e distais de cada implante, sendo reservadas 6 colunas para este fim, pois se houvesse 3 implantes seria necessário utilizar todos os campos. Com esta análise comparando-se as medidas das radiografias iniciais com as subseqüentes foi obtida a mensuração da perda óssea em cada implante, durante os dois anos de acompanhamento. 
Desenvolveu-se no programa Delphi 4.0 um programa específico para digitação de todos os dados clínicos. Foram estabelecidas e utilizadas siglas para cada variável de cada item da ficha e estas se encontram no item Apêndice 2. As siglas utilizadas para abreviação do nome do paciente encontram-se dispostas em 3 quadros sucessivos, sendo que foram omitidos os sobrenomes de cada paciente com a finalidade de preservar a intimidade destes. No final desta tabela encontrase a soma do número de pacientes atendidos em cada exame. A seguir foram apresentadas as siglas utilizadas para as seguintes itens:

- sexo;

- idade;

- arcada restaurada por prótese sobre implante;

- fumante;

- número de cigarros ao dia;

- submetido a radioterapia;

- realização de enxerto ósseo;

- número de implantes classificados de acordo com a tabela de quatro campos proposta por ALBREKTSSON; ZARB ${ }^{13}$, do ano de 1993;

- tipo de prótese da maxila e mandíbula

- complicações na maxila

- complicações na mandíbula

- profundidade de sondagem vestibular

- profundidade de sondagem lingual

- nivel de inserção na vestibular

- nível de inserção na lingual

- placa na vestibular

- placa na lingual

- sangramento

- edema

- coloração

- mobilidade

- supuração 
- notas aferidas pelos pacientes

Os dados digitados foram avaliados no programa Systat, específico para analises estatísticas. Neste programa foi efetuada a contabilização das siglas devidamente e estas foram decodificadas obtendo-se a mensuração de cada item. 


\section{5-RESULTADOS}




\section{5-RESULTADOS}

Conforme descrito no item material e métodos os dados clínicos dos quatro exames foram digitados em programa específico. Estes foram posteriormente analisados, através do programa Systat, obtendo-se os seguintes resultados:

Tabela n6: Número e percentual de pacientes em relação ao sexo.

\begin{tabular}{c|c|c}
\hline & Número & Percentual \\
\hline Feminino & 66 & $60.66 \%$ \\
\hline Masculino & 43 & $39.44 \%$ \\
\hline Total & 109 & $100 \%$ \\
\hline
\end{tabular}

Tabela n7: Apresentação da idade máxima, mínima, média e desvio padrão dos pacientes.

\begin{tabular}{c|c}
\hline & Idade \\
\hline Idade mínima & 17 \\
\hline Idade máxima & 82 \\
\hline Média & 51.94 \\
\hline Desvio padrão & 12.88 \\
\hline
\end{tabular}

Tabela n`8:Distribuição do número e percentual de pacientes agrupados por faixas etárias.

\begin{tabular}{l|c|c}
\hline & $\begin{array}{c}\text { Número de } \\
\text { pacientes }\end{array}$ & $\begin{array}{c}\text { Percentual de } \\
\text { pacientes }\end{array}$ \\
\hline $\mathbf{1 7 - 3 0}$ & 8 & $7.33 \%$ \\
\hline $\mathbf{3 1 - 4 0}$ & 9 & $8.26 \%$ \\
\hline $\mathbf{4 1 - 5 0}$ & 31 & $28.44 \%$ \\
\hline $\mathbf{5 1 - 6 0}$ & 31 & $28.44 \%$ \\
\hline $\mathbf{6 1 - 7 0}$ & 24 & $22.02 \%$ \\
\hline $\mathbf{7 1 - 8 2}$ & 6 & $5.51 \%$ \\
\hline Total & 109 & $100 \%$ \\
\hline
\end{tabular}


Tabela n`9: Número e percentual de pacientes e número de implantes na maxila, mandibula e total avaliados nos quatro exames.

\begin{tabular}{l|c|c|c|c}
\cline { 2 - 5 } & $\mathbf{N}^{\circ}$ de pacientes & \multicolumn{3}{|c}{$\mathrm{N}^{\circ}$ de implantes avaliados } \\
\cline { 2 - 5 } $\mathbf{1}^{\circ}$ exame & $109(100 \%)$ & 106 & 265 & Maxila \\
\hline $\mathbf{2}^{\circ}$ exame & $103(94.49 \%)$ & 99 & 253 & 352 \\
\hline $\mathbf{3}^{\circ}$ exame & $99(90.82 \%)$ & 92 & 234 & 326 \\
\hline $\mathbf{4}^{\circ}$ exame & $89(81.65 \%)$ & 92 & 219 & 311 \\
\hline
\end{tabular}

Tabela n 10: Número de pacientes não-fumantes e fumantes.

\begin{tabular}{c|c|c|c}
\hline & Sexo feminino & Sexo masculino & Total \\
\hline Não-fumantes & 54 & 35 & 89 \\
\hline Fumantes & 12 & 8 & 20 \\
\hline Total & 66 & 43 & 109 \\
\hline
\end{tabular}

Tabela $\mathbf{n}^{\circ}$ 11: Demonstração da média do número de cigarros e desvio padrão em pacientes fumantes.

\begin{tabular}{c|c|c}
\hline & $\begin{array}{c}\text { Média do número de } \\
\text { cigarros ao dia }\end{array}$ & $\begin{array}{c}\text { Desvio } \\
\text { padrão }\end{array}$ \\
\hline Fumantes & 11.5 & 6.363 \\
\hline
\end{tabular}

Tabela $\mathbf{n}^{\circ}$ 12: Distribuição do sexo em relação ao hábito de fumar submetidos a estatística pelo teste Pearson Chi-square.

\begin{tabular}{c|c|c|c}
\hline Teste estatístico & Valor & Probabilidade \\
\hline Pearson Chi-square & 0.003 & 0.956 \\
\hline O valor obtido não demonstrou correlação na distribuição
\end{tabular}
diferenciada entre fumo e sexo. 
Tabela $\mathbf{n}^{\circ}$ 13:Apresentação do número e percentual de pacientes submetidos ou não a enxerto ósseo e radioterapia.

\begin{tabular}{l|c|c}
\hline & $\begin{array}{c}\text { Número e percentual de } \\
\text { pacientes }\end{array}$ & $\begin{array}{c}\text { Número de falhas de } \\
\text { implantes }\end{array}$ \\
\hline Não submetidos a radiação & $109(100 \%)$ & - \\
\hline Submetidos a radiação & $0(0 \%)$ & 18 \\
\hline Não submetidos a enxerto & $102(93.57 \%)$ & 0 \\
\hline Submetidos a enxerto ósseo & $7(6.43 \%)$ & - \\
\hline
\end{tabular}

Nenhum dos pacientes examinados foi submetido a radioterapia e 7

foram submetidos a enxerto ósseo autógeno de área doadora intra-bucal. As

falhas se concentram somente nos pacientes não submetidos a enxerto.

Tabela $\mathbf{n}^{\circ}$ 14:Número de pacientes, e número e percentual de implantes subdivididos pelo número de implantes por paciente.

\begin{tabular}{c|c|c|c}
\hline $\begin{array}{c}\mathbf{N}^{\circ} \text { de implantes } \\
\text { por paciente }\end{array}$ & $\mathbf{N}^{\circ}$ de pacientes & $\mathbf{N}^{\circ}$ de implantes & $\begin{array}{c}\text { Percentual do } \mathbf{n}^{\circ} \text { de } \\
\text { implantes }\end{array}$ \\
\hline 1 & 16 & 16 & $4.31 \%$ \\
\hline 2 & 31 & 62 & $16.72 \%$ \\
\hline 3 & 17 & 51 & $13.75 \%$ \\
\hline 4 & 10 & 40 & $10.78 \%$ \\
\hline 5 & 18 & 90 & $24.25 \%$ \\
\hline 6 & 12 & 72 & $19.40 \%$ \\
\hline 7 & 2 & 14 & $\mathbf{3 . 7 8} \%$ \\
\hline 8 & 1 & 16 & $2.32 \%$ \\
\hline 10 & 109 & 10 & $100 \%$ \\
\hline Total & & 371 & \\
\hline
\end{tabular}


Tabela $\mathbf{n}^{\circ}$ 15:Número de pacientes e implantes, subdivididos pelo número de implantes por paciente na mandíbula, maxila, e maxila e mandibula.

\begin{tabular}{|c|c|c|c|c|c|c|c|}
\hline & \multicolumn{2}{|c|}{ Maxila } & \multicolumn{2}{|c|}{ Mandíbula } & \multicolumn{2}{|c|}{ Maxila e mandíbula } & \\
\hline $\begin{array}{c}\mathbf{N}^{\circ} \text { de implantes } \\
\text { por paciente }\end{array}$ & $\begin{array}{c}\mathbf{N}^{\circ} \mathrm{de} \\
\text { pacientes }\end{array}$ & $\begin{array}{c}\mathbf{N}^{\circ} \text { de } \\
\text { implantes }\end{array}$ & $\begin{array}{c}\mathbf{N}^{\circ} \text { de } \\
\text { pacientes }\end{array}$ & $\begin{array}{c}\mathbf{N}^{\circ} \text { de } \\
\text { implantes }\end{array}$ & $\begin{array}{c}\mathbf{N}^{\circ} \text { de } \\
\text { pacientes }\end{array}$ & $\begin{array}{c}\mathbf{N}^{\circ} \text { de } \\
\text { implantes }\end{array}$ & $\begin{array}{c}\text { Total de } \\
\text { pacientes }\end{array}$ \\
\hline $\mathbf{1}$ & 13 & 13 & 3 & 3 & $\mathbf{0}$ & $\mathbf{0}$ & 16 \\
\hline 2 & 7 & $\overline{14}$ & 24 & 48 & $\mathbf{0}$ & $\mathbf{0}$ & 31 \\
\hline 3 & 6 & 18 & $\overline{11}$ & 33 & $\mathbf{0}$ & $\mathbf{0}$ & 17 \\
\hline 4 & $\mathbf{0}$ & $\mathbf{0}$ & 10 & 40 & $\mathbf{0}$ & $\mathbf{0}$ & 10 \\
\hline 5 & $\mathbf{0}$ & $\mathbf{0}$ & 15 & 75 & 3 & $\mathbf{1 5}$ & 18 \\
\hline 6 & 3 & 18 & 8 & 48 & $\mathbf{1}$ & 6 & 12 \\
\hline 7 & $\mathbf{1}$ & 7 & $\mathbf{1}$ & 7 & $\mathbf{0}$ & $\mathbf{0}$ & 2 \\
\hline 8 & 2 & 16 & $\mathbf{0}$ & $\mathbf{0}$ & $\mathbf{0}$ & $\mathbf{0}$ & 2 \\
\hline 10 & $\mathbf{0}$ & $\mathbf{0}$ & $\mathbf{0}$ & $\mathbf{0}$ & $\mathbf{1}$ & 10 & $\mathbf{1}$ \\
\hline Total & 32 & 86 & 72 & 254 & 5 & 31 & 109 \\
\hline
\end{tabular}


Tabela $\mathbf{n}^{\circ}$ 16:Número de implantes classificados de acordo com a tabela de quatr campos de ALBREKTSSON, ZARB, $1993^{13}$ nos quatro exames

\begin{tabular}{|c|c|c|c|c|c|c|c|c|c|c|c|}
\hline & \multicolumn{11}{|c|}{$\mathbf{N}^{\circ}$. de implantes } \\
\hline & \multicolumn{2}{|c|}{ Sucesso } & \multicolumn{2}{|c|}{ Sobrevivência } & \multicolumn{2}{|c|}{ Não computado } & \multicolumn{2}{|c|}{ Falhas } & \multicolumn{3}{|c|}{ Total } \\
\hline rame & Maxila & Mandíbula & Maxila & Mandíbula & \begin{tabular}{|l|} 
Maxila \\
\end{tabular} & Mandíbula & Maxila & Mandíbula & Maxila & Mandíbula & Total \\
\hline$\overline{\mathbf{1}^{\circ}}$ & 99 & 260 & $\mathbf{0}$ & $\mathbf{0}$ & $\mathbf{0}$ & $\mathbf{0}$ & 7 & 5 & 106 & 265 & 371 \\
\hline$\overline{\mathbf{2}^{\circ}}$ & 92 & 248 & $\mathbf{0}$ & $\mathbf{0}$ & 7 & 12 & 7 & 5 & 106 & 265 & 371 \\
\hline $\mathbf{3}^{\circ}$ & 84 & 229 & $\mathbf{0}$ & $\begin{array}{c}\mathbf{0} \\
\end{array}$ & 14 & $\mathbf{3 1}$ & 8 & 5 & 106 & 265 & 371 \\
\hline $4^{\circ}$ & 83 & 210 & $\mathbf{0}$ & $\mathbf{0}$ & 14 & 46 & 9 & 9 & 106 & 265 & 371 \\
\hline
\end{tabular}

Tabela $\mathbf{n}^{\circ}$ 17:Percentual de implantes classificados de acordo com a tabela de quatrı campos de ALBREKTSSON, ZARB, 199313, nos quatro exames

\begin{tabular}{|c|c|c|c|c|c|c|c|c|}
\hline & \multicolumn{8}{|c|}{ Percentual de implantes } \\
\hline & \multicolumn{2}{|c|}{ Sucesso } & \multicolumn{2}{|c|}{ Sobrevivência } & \multicolumn{2}{|c|}{ Não computado } & \multicolumn{2}{|c|}{ Falhas } \\
\hline Exame & Maxila & Mandíbula & Maxila & Mandíbula & Maxila & Mandíbula & Maxila & Mandíbula \\
\hline $1^{\circ}$ & $93.40 \%$ & $98.12 \%$ & $\mathbf{0}$ & $\mathbf{0}$ & $\mathbf{0}$ & $\mathbf{0}$ & $6.60 \%$ & $1.88 \%$ \\
\hline $\mathbf{2}^{\circ}$ & $\mathbf{8 6 . 8 0 \%}$ & $93.58 \%$ & $\mathbf{0}$ & $\mathbf{0}$ & $6.60 \%$ & 4.52\% & $6.60 \%$ & $1.88 \%$ \\
\hline $\mathbf{3}^{\circ}$ & $79.24 \%$ & $86.41 \%$ & $\mathbf{0}$ & $\mathbf{0}$ & $13.20 \%$ & $11.69 \%$ & $\mathbf{7 . 5 4 \%}$ & $1.88 \%$ \\
\hline $4^{\circ}$ & $\mathbf{7 8 . 3 0 \%}$ & $79.24 \%$ & $\mathbf{0}$ & $\mathbf{0}$ & $13.20 \%$ & $17.35 \%$ & $8.49 \%$ & 3.39\% \\
\hline
\end{tabular}

Tabela n 18: Apresentação do percentual de sucesso e falha dos implantes, $\epsilon$ estabilidade das próteses.

\begin{tabular}{c|c|c|c|c|c|c}
\hline & \multicolumn{2}{|c|}{ Sucesso } & \multicolumn{2}{c|}{ Falhas } & \multicolumn{2}{c}{$\begin{array}{c}\text { Estabilidade da } \\
\text { prótese }\end{array}$} \\
\hline Exame & Maxila & Mandíbula & Maxila & Mandíbula & Maxila & Mandíbula \\
\hline $1^{\circ}$ & $\mathbf{9 3 . 3 9 \%}$ & $\mathbf{9 8 . 1 2} \%$ & $\mathbf{6 . 6 1 \%}$ & $\mathbf{1 . 8 8} \%$ & $\mathbf{1 0 0 \%}$ & $\mathbf{1 0 0 \%}$ \\
\hline $\mathbf{2}^{\circ}$ & $\mathbf{9 6 . 9 3 \%}$ & $\mathbf{9 8 . 0 3 \%}$ & $\mathbf{7 . 0 7 \%}$ & $\mathbf{1 . 9 7 \%}$ & $\mathbf{1 0 0 \%}$ & $\mathbf{1 0 0 \%}$ \\
\hline $\mathbf{3}^{\circ}$ & $\mathbf{9 4 . 3 7 \%}$ & $\mathbf{9 7 . 8 7 \%}$ & $\mathbf{5 . 7 3} \%$ & $\mathbf{2 . 1 3} \%$ & $\mathbf{1 0 0 \%}$ & $\mathbf{1 0 0 \%}$ \\
\hline $4^{\circ}$ & $\mathbf{9 0 . 2 1 \%}$ & $\mathbf{9 5 . 9 0 \%}$ & $\mathbf{9 . 8} \%$ & $\mathbf{4 . 1 0} \%$ & $\mathbf{9 9 . 2 5 \%}$ & $\mathbf{1 0 0 \%}$ \\
\hline
\end{tabular}


Tabela $\mathbf{n}^{\circ}$ 19:Distribuição das falhas dos implantes nos pacientes, em relação a localização, hábito de fumar, tipo de prótese, comprimento e ao momento de detecção desta, sendo removido ou adormecido.

\begin{tabular}{|c|c|c|c|c|c|c|c|c|c|c|}
\hline \multirow{3}{*}{$\begin{array}{l}\text { Sigla do } \\
\text { paciente }\end{array}$} & \multicolumn{2}{|c|}{$\mathbf{N}^{\circ}$ de falhas } & \multirow{3}{*}{$\begin{array}{c}\text { Fumante } \\
\mathbf{S} \\
\left(\mathrm{N}^{\circ}\right. \\
\text { cigarros) }\end{array}$} & \multicolumn{2}{|c|}{$\begin{array}{l}\text { Tipo de } \\
\text { prótese }\end{array}$} & \multicolumn{2}{|c|}{ Comprimento } & \multicolumn{3}{|c|}{ Detecção das falhas } \\
\hline & \multirow[t]{2}{*}{ Max. } & \multirow[t]{2}{*}{ Man. } & & \multirow[t]{2}{*}{ Max. } & \multirow[t]{2}{*}{ Man. } & \multirow[t]{2}{*}{ Max. } & \multirow[t]{2}{*}{ Man. } & \multicolumn{2}{|c|}{$2^{\circ}$ cirurgia } & \multirow[t]{2}{*}{ Exame } \\
\hline & & & & & & & & Remoção & Adormecido & \\
\hline A8 & - & $\mathbf{1}$ & - & - & $\mathbf{C}$ & - & 10 & $\mathbf{X}$ & - & - \\
\hline $\mathbf{C 4}$ & - & $\mathbf{1}$ & - & - & $\mathbf{C}$ & - & 10 & $\mathbf{X}$ & - & - \\
\hline D1 & - & $\mathbf{1}$ & - & - & $\mathbf{D}$ & - & 10 & - & $\mathbf{X}$ & - \\
\hline$\overline{D 4}$ & - & $\mathbf{1}$ & - & - & $\mathbf{D}$ & - & 8.5 & - & - & $4^{\circ}$ \\
\hline E3 & - & $\mathbf{1}$ & $\mathbf{S}(\mathbf{3 0})$ & - & $\mathbf{A}$ & - & 7.0 & $\mathbf{X}$ & - & \\
\hline F2 & $\begin{array}{l}\mathbf{1} \\
\mathbf{1}\end{array}$ & - & S (10) & $\mathbf{C}$ & - & $\begin{array}{l}7.0 \\
10\end{array}$ & - & $\begin{array}{l}\mathbf{X} \\
-\end{array}$ & $\begin{array}{l}- \\
\mathbf{X}\end{array}$ & - \\
\hline G3 & $\mathbf{1}$ & - & - & $\mathbf{C}$ & - & 8.5 & - & $\mathbf{X}$ & - & - \\
\hline G7 & - & $\mathbf{1}$ & - & - & $\mathbf{E}$ & - & 7 & - & - & $4^{\circ}$ \\
\hline H2 & $\mathbf{1}$ & - & S (15) & $\mathbf{A}$ & - & 8.5 & - & - & - & $\mathbf{3}^{\circ}$ \\
\hline H7 & - & $\begin{array}{l}\mathbf{1} \\
\mathbf{1} \\
\mathbf{1}\end{array}$ & $\begin{array}{l}- \\
-\end{array}$ & - & $\begin{array}{l}- \\
\text { D } \\
\text { D }\end{array}$ & - & $\begin{array}{l}7 \\
7 \\
7\end{array}$ & $\begin{array}{l}\mathbf{X} \\
- \\
-\end{array}$ & $\begin{array}{l}- \\
-\end{array}$ & $\begin{array}{l}- \\
4^{\circ} \\
4^{\circ}\end{array}$ \\
\hline J1 & $\mathbf{1}$ & - & - & B & - & 8.5 & - & $\mathbf{X}$ & - & - \\
\hline J2 & $\mathbf{1}$ & - & S (20) & $\mathbf{C}$ & - & - & 8.5 & - & $\mathbf{X}$ & - \\
\hline M2 & $\begin{array}{l}\mathbf{1} \\
\mathbf{1} \\
\mathbf{1}\end{array}$ & - & $\begin{array}{l}- \\
-\end{array}$ & $\begin{array}{l}- \\
\text { D } \\
\text { D }\end{array}$ & $\begin{array}{l}- \\
-\end{array}$ & $\begin{array}{l}8.5 \\
8.5 \\
8.5\end{array}$ & - & $\begin{array}{l}\mathbf{X} \\
\mathbf{X} \\
-\end{array}$ & $\begin{array}{l}- \\
-\end{array}$ & $\begin{array}{l}- \\
- \\
4^{\circ}\end{array}$ \\
\hline $\begin{array}{c}\text { Total de } \\
\text { implantes }\end{array}$ & 9 & 9 & 5 & - & - & - & - & 9 & 3 & 6 \\
\hline
\end{tabular}

Nesta tabela demonstra-se concentração das falhas até a segunda fase cirúrgica, sendo que todas as falhas foram em implantes curtos, variando de 7 a $10 \mathrm{~mm}$. Não houve acentuação das falhas no pacientes fumantes com concentração de $27.77 \%$ das falhas. Obs: Max. $=$ maxila $/$ Man. $=$ mandibula $/ \mathrm{S}=$ sim. As siglas utilizadas para os pacientes e tipos de prótese estão incluídas no Apêndice 2. 
Tabela $\mathbf{n}^{\circ}$ 20: Número de pacientes com implantes na maxila, classificados de acordo com a tabela de quatro campos de ALBREKTSSON, ZARB, 199313, no $1^{\circ}$ exame, e subdivididos pelo número de implantes por paciente.

\begin{tabular}{c|c|c|c|c|c}
\hline $\begin{array}{c}\text { Número de } \\
\text { implantes } \\
\text { por paciente }\end{array}$ & $\begin{array}{c}\text { Sucesso } \\
\text { "S" }\end{array}$ & $\begin{array}{c}\text { Sobrevivência } \\
\text { "Sob." }\end{array}$ & $\begin{array}{c}\text { Não-computado } \\
\text { "N-C" }\end{array}$ & Falhas "F" & $\begin{array}{c}\text { Frequência } \\
\text { Total }\end{array}$ \\
\hline 0 & $\mathbf{7 1 ( 6 5 . 1 \% )}$ & $109(100 \%)$ & $109(100 \%)$ & $103(94.51 \%)$ & $71(65.13 \%)$ \\
\hline 1 & $13(11.9 \%)$ & 0 & 0 & $5(4.58 \%)$ & $12(11.00 \%)$ \\
\hline 2 & $11(10 \%)$ & 0 & 0 & $1(0.91)$ & $10(9.17 \%)$ \\
\hline 3 & $7(6.49 \%)$ & 0 & 0 & 0 & $9(8.25 \%)$ \\
\hline 4 & - & - & - & - & - \\
\hline 5 & $3(2.85 \%)$ & 0 & 0 & 0 & $1(0.91 \%)$ \\
\hline 6 & $2(1.83 \%)$ & 0 & 0 & - & $12.75 \%)$ \\
\hline 7 & - & - & 0 & 0 & $2(1.83 \%)$ \\
\hline 8 & $2(1.83 \%)$ & 0 & $109(100 \%)$ & $109(100 \%)$ & $109(100 \%)$ \\
\hline Total & $109(100 \%)$ & $109(100 \%)$ & & $0.91 \%)$ \\
\hline
\end{tabular}

Tabela $\mathbf{n}^{\circ 21}$ : Número de pacientes com implantes na mandíbula, classificados de acordo com tabela de quatro campos de ALBREKTSSON, ZARB, 199313, no $1^{\circ}$ exame, subdivididos pelo número de implantes por paciente,.

\begin{tabular}{|c|c|c|c|c|c|}
\hline $\begin{array}{c}\text { Número de } \\
\text { implantes por } \\
\text { paciente }\end{array}$ & $\begin{array}{c}\text { Sucesso } \\
\text { "S" }\end{array}$ & $\begin{array}{c}\text { Sobrevivência } \\
\text { "Sob." }\end{array}$ & $\begin{array}{c}\text { Não- computado } \\
\text { "N-C" }\end{array}$ & Falhas "F" & $\begin{array}{c}\text { Frequência } \\
\text { Total }\end{array}$ \\
\hline $\mathbf{0}$ & 34 (31.1\%) & $109(100 \%)$ & 109 (100\%) & $104(95.41 \%)$ & 35 (32.12\%) \\
\hline $\mathbf{1}$ & 3 (2.75\%) & $\mathbf{0}$ & $\mathbf{0}$ & $5(4.58 \%)$ & $3(2.75 \%)$ \\
\hline 2 & 26 (23.95\%) & $\mathbf{0}$ & $\mathbf{0}$ & $\mathbf{0}$ & $24(22.02 \%)$ \\
\hline 3 & $11(10 \%)$ & $\mathbf{0}$ & $\mathbf{0}$ & $\mathbf{0}$ & $11(10.09 \%)$ \\
\hline 4 & $10(9.18 \%)$ & $\mathbf{0}$ & $\mathbf{0}$ & $\mathbf{0}$ & $11(10.09 \%)$ \\
\hline 5 & $19(17.53)$ & $\mathbf{0}$ & $\mathbf{0}$ & $\mathbf{0}$ & $16(14.68 \%)$ \\
\hline 6 & 5 (4.58\%) & $\mathbf{0}$ & $\mathbf{0}$ & $\mathbf{0}$ & $8(7.34 \%)$ \\
\hline 7 & $1(0.91 \%)$ & $\mathbf{0}$ & $\mathbf{0}$ & $\mathbf{0}$ & $1(0.91)$ \\
\hline 8 & - & - & - & - & - \\
\hline Total & $109(100 \%)$ & 109 (100\%) & 109(100\%) & $109(100 \%)$ & $109(100 \%)$ \\
\hline
\end{tabular}


Tabela $\mathbf{n}^{\circ}$ 22: Número de pacientes com implantes na maxila, classificados de acordo com a tabela de quatro campos de ALBREKTSSON, ZARB, 199313, no $2^{\circ}$ exame, e subdivididos pelo número de implantes por paciente.

\begin{tabular}{|c|c|c|c|c|c|}
\hline $\begin{array}{l}\text { Número de } \\
\text { implantes } \\
\text { por paciente }\end{array}$ & $\begin{array}{c}\text { Sucesso } \\
\text { "S" }\end{array}$ & $\begin{array}{c}\text { Sobrevivência } \\
\text { "Sob." }\end{array}$ & $\begin{array}{c}\text { Não- computado } \\
\text { "N-C" }\end{array}$ & Falhas "F" & $\begin{array}{c}\text { Frequência } \\
\text { Total }\end{array}$ \\
\hline $\mathbf{0}$ & $74(68.23 \%)$ & 109 (100\%) & $106(97.24 \%)$ & 105 (96.34\%) & $72(66.90 \%)$ \\
\hline $\mathbf{1}$ & $13(11.8 \%)$ & $\mathbf{0}$ & $\mathbf{0}$ & 5 (4.58\%) & $13(11.21 \%)$ \\
\hline 2 & $9(8.18 \%)$ & $\mathbf{0}$ & $2(1.83 \%)$ & $1(0.91 \%)$ & $10(9.11 \%)$ \\
\hline 3 & 6 (5.45\%) & $\mathbf{0}$ & $1(0.91 \%)$ & $\mathbf{0}$ & $8(7.35 \%)$ \\
\hline 4 & - & - & - & - & - \\
\hline 5 & $3(2.72 \%)$ & $\mathbf{0}$ & $\mathbf{0}$ & $\mathbf{0}$ & $2(1.81 \%)$ \\
\hline 6 & 2 (1.81\%) & $\mathbf{0}$ & $\mathbf{0}$ & $\mathbf{0}$ & $2(1.81 \%)$ \\
\hline 7 & - & - & - & - & - \\
\hline 8 & 2 (1.81\%) & $\mathbf{0}$ & $\mathbf{0}$ & $\mathbf{0}$ & 2 (1.81\%) \\
\hline Total & $109(100 \%)$ & $109(100 \%)$ & $109(100 \%)$ & 109 & $109(100 \%)$ \\
\hline
\end{tabular}


tabela de quatro campos de ALBREKTSSON, ZARB, 199313, no $2^{\circ}$ exame, e subdivididos pelo número de implantes por paciente.

\begin{tabular}{c|c|c|c|c|c}
\hline $\begin{array}{c}\text { Número de } \\
\text { implantes por } \\
\text { paciente }\end{array}$ & $\begin{array}{c}\text { Sucesso } \\
\text { ("S") }\end{array}$ & $\begin{array}{c}\text { Sobrevivência } \\
\text { ("Sob.") }\end{array}$ & $\begin{array}{c}\text { Não- computado } \\
\text { ("N-C") }\end{array}$ & Falhas ("F") & $\begin{array}{c}\text { Frequência } \\
\text { Total }\end{array}$ \\
\hline 0 & $\mathbf{3 9}(36.7 \%)$ & $109(100 \%)$ & $104(95.49 \%)$ & $104(95.42 \%)$ & $34(31.19 \%)$ \\
\hline 1 & $3(2 \%)$ & 0 & 0 & $5(4.58 \%)$ & $3(2.76 \%)$ \\
\hline 2 & $22(20.6 \%)$ & 0 & $4(3.6 \%)$ & 0 & $25(22.94 \%)$ \\
\hline 3 & $11(10 \%)$ & 0 & 0 & 0 & $11(10.09 \%)$ \\
\hline 4 & $9(8 \%)$ & 0 & $1(0.91)$ & 0 & $11(10.09 \%)$ \\
\hline 5 & $19(17.8 \%)$ & 0 & 0 & 0 & $16(14.69 \%)$ \\
\hline 6 & $5(4 \%)$ & 0 & 0 & 0 & $\mathbf{8}(7.33 \%)$ \\
\hline 7 & $1(0.90 \%)$ & 0 & 0 & 0 & $1(0.91 \%)$ \\
\hline 8 & - & - & - & - & - \\
\hline Total & $109(100 \%)$ & $109(100 \%)$ & $109(100 \%)$ & $109(100 \%)$ & $109(100 \%)$ \\
\hline
\end{tabular}


Tabela $\mathbf{n}^{\circ}$ 24:Número de pacientes com implantes na maxila, classificados de acordo com a tabela de quatro campos de ALBREKTSSON, ZARB, 199313 , no $3^{\circ}$ exame, e subdivididos pelo número de implantes por paciente.

\begin{tabular}{|c|c|c|c|c|c|}
\hline $\begin{array}{l}\text { Número de } \\
\text { implantes } \\
\text { por paciente }\end{array}$ & $\begin{array}{c}\text { Sucesso } \\
\text { “S" }\end{array}$ & $\begin{array}{c}\text { Sobrevivência } \\
\text { "Sob." }\end{array}$ & $\begin{array}{c}\text { Não- computado } \\
\text { "N-C" }\end{array}$ & Falhas "F" & $\begin{array}{c}\text { Frequência } \\
\text { Total }\end{array}$ \\
\hline 0 & 75 (68.8\%) & $109(100 \%)$ & 105 (96.36\%) & $102(93.59 \%)$ & 72 (66.06\%) \\
\hline $\mathbf{1}$ & 13 (11.9\%) & $\mathbf{0}$ & $1(0.91 \%)$ & $6(5.50 \%)$ & $13(11.93 \%)$ \\
\hline 2 & $9(8.29 \%)$ & $\mathbf{0}$ & $1(0.91 \%)$ & $1(0.91 \%)$ & 9 (8.26\%) \\
\hline 3 & $6(5.52 \%)$ & $\mathbf{0}$ & $1(0.91 \%)$ & $\mathbf{0}$ & $9(8.26 \%)$ \\
\hline 4 & - & - & - & - & - \\
\hline 5 & 3 (2.75\%) & $\mathbf{0}$ & $\mathbf{0}$ & $\mathbf{0}$ & $1(0.91 \%)$ \\
\hline 6 & 2 (1.83\%) & $\mathbf{0}$ & $\mathbf{0}$ & $\mathbf{0}$ & 3 (2.75\%) \\
\hline 7 & - & - & - & - & - \\
\hline 8 & $1(0.91 \%)$ & $\mathbf{0}$ & $1(0.91 \%)$ & $\mathbf{0}$ & $2(1.83 \%)$ \\
\hline Total & $109(100 \%)$ & $109(100 \%)$ & $109(100 \%)$ & $109(100 \%)$ & $109(100 \%)$ \\
\hline
\end{tabular}

Tabela $\mathbf{n}^{\circ 25}$ : Número de pacientes com implantes na mandíbula, classificados de acordo com a tabela de quatro campos de ALBREKTSSON, ZARB, 199313, no $3^{\circ}$ exame, e subdivididos pelo número de implantes por paciente.

\begin{tabular}{c|c|c|c|c|c}
\hline $\begin{array}{c}\text { Número de } \\
\text { implantes } \\
\text { por paciente }\end{array}$ & $\begin{array}{c}\text { Sucesso } \\
\text { ("S") }\end{array}$ & $\begin{array}{c}\text { Sobrevivência } \\
\text { ("Sob.") }\end{array}$ & $\begin{array}{c}\text { Não- computado } \\
\text { ("N-C") }\end{array}$ & Falhas ("F") & $\begin{array}{c}\text { Frequência } \\
\text { Total }\end{array}$ \\
\hline 0 & $44(40.39 \%)$ & $109(100 \%)$ & $97(88.99 \%)$ & $104(95.42 \%)$ & $34(31.19 \%)$ \\
\hline 1 & $2(1.84 \%)$ & 0 & 0 & $5(4.58 \%)$ & $2(1.835 \%)$ \\
\hline 2 & $23(21.1 \%)$ & 0 & $6(5.52 \%)$ & 0 & $27(24.77 \%)$ \\
\hline 3 & $10(9.17 \%)$ & 0 & $2(1.83 \%)$ & 0 & $12(11.00 \%)$ \\
\hline 4 & $\mathbf{8 ( 7 . 3 3 \% )}$ & 0 & $2(1.83 \%)$ & 0 & $10(9.17 \%)$ \\
\hline 5 & $15(13.76 \%)$ & 0 & $1(0.91 \%)$ & 0 & $15(13.76 \%)$ \\
\hline 6 & $6(5.5 \%)$ & 0 & 0 & 0 & $8(7.339 \%)$ \\
\hline 7 & $1(0.91 \%)$ & 0 & 0 & 0 & $1(0.91 \%)$ \\
\hline 8 & - & - & - & - & $109(100 \%)$ \\
\hline Total & $109(100 \%)$ & $109(100 \%)$ & $109(100 \%)$ & $109(100 \%)$ & 109 \\
\hline
\end{tabular}


Tabela n²6: Número de pacientes com implantes na maxila, classificados de acordo com a tabela de quatro campos de ALBREKTSSON, ZARB, $1993^{13}$, no $4^{\circ}$ exame, e subdivididos pelo número de implantes por paciente.

\begin{tabular}{|c|c|c|c|c|c|}
\hline $\begin{array}{c}\text { Número de } \\
\text { implantes } \\
\text { por paciente }\end{array}$ & $\begin{array}{c}\text { Sucesso } \\
\text { "S" }\end{array}$ & $\begin{array}{c}\text { Sobrevivência } \\
\text { "Sob." }\end{array}$ & $\begin{array}{c}\text { Não- computado } \\
\text { "N-C" }\end{array}$ & Falhas "F" & $\begin{array}{c}\text { Frequência } \\
\text { Total }\end{array}$ \\
\hline 0 & 76 (69.72\%) & $107(98.12 \%)$ & 105 (96.36\%) & 98 (91.58\%) & 71 (65.13\%) \\
\hline $\mathbf{1}$ & $11(10.09 \%)$ & $\mathbf{0}$ & $1(0.91 \%)$ & 8 (5.50\%) & $13(11.91 \%)$ \\
\hline 2 & $8(7.33 \%)$ & $\mathbf{0}$ & $1(0.91 \%)$ & $1(0.91 \%)$ & $10(9.17 \%)$ \\
\hline 3 & 5 (4.78\%) & $\mathbf{0}$ & $1(0.91 \%)$ & $\mathbf{0}$ & $7(6.42 \%)$ \\
\hline 4 & - & - & - & - & - \\
\hline 5 & 3 (2.75\%) & $\overline{0}$ & $\mathbf{0}$ & $\overline{0}$ & $1(0.91 \%)$ \\
\hline 6 & 3 (2.75\%) & $\mathbf{0}$ & $\mathbf{0}$ & $\mathbf{0}$ & 3 (2.75\%) \\
\hline 7 & - & - & - & - & - \\
\hline 8 & $1(0.91 \%)$ & $\mathbf{0}$ & $1(0.91 \%)$ & $\mathbf{0}$ & $2(1.83 \%)$ \\
\hline Total & $107(98.12 \%)$ & $107(98.12 \%)$ & $109(100 \%)$ & $107(98.12 \%)$ & $107(98.12 \%)$ \\
\hline
\end{tabular}

Tabela n²7:Número de pacientes com implantes na mandíbula, classificados de acordo com a tabela de quatro campos de ALBREKTSSON, ZARB, 199313, no $4^{\circ}$ exame, e subdivididos pelo número de implantes por paciente.

\begin{tabular}{|c|c|c|c|c|c|}
\hline $\begin{array}{l}\text { Número de } \\
\text { implantes } \\
\text { por paciente }\end{array}$ & $\begin{array}{c}\text { Sucesso } \\
\text { (“S") }\end{array}$ & $\begin{array}{c}\text { Sobrevivência } \\
\text { (“Sob.") }\end{array}$ & $\begin{array}{c}\text { Não- computado } \\
\text { ("N-C") }\end{array}$ & Falhas ("F") & $\begin{array}{c}\text { Frequência } \\
\text { Total }\end{array}$ \\
\hline $\mathbf{0}$ & $47(43.11 \%)$ & $107(100 \%)$ & 93 (85.33\%) & $99(90.81 \%)$ & $32(29.35 \%)$ \\
\hline 1 & $3(2.75 \%)$ & $\mathbf{0}$ & $1(0.91 \%)$ & $7(6.40 \%)$ & $4(3.66 \%)$ \\
\hline 2 & $19(17.43 \%)$ & $\mathbf{0}$ & $8(7.36 \%)$ & $1(0.91 \%)$ & 26 (23.85\%) \\
\hline 3 & $9(8.25 \%)$ & $\mathbf{0}$ & $2(1.83 \%)$ & $\mathbf{0}$ & $12(11.00 \%)$ \\
\hline 4 & $8(7.33 \%)$ & $\mathbf{0}$ & $1(0.91 \%)$ & $\mathbf{0}$ & $10(9.17 \%)$ \\
\hline 5 & $16(14.67 \%)$ & $\mathbf{0}$ & $3(2.75 \%)$ & $\mathbf{0}$ & $15(13.76 \%)$ \\
\hline 6 & $5(4.58 \%)$ & $\mathbf{0}$ & $1(0.91 \%)$ & $\mathbf{0}$ & $7(6.42 \%)$ \\
\hline 7 & $\mathbf{0}$ & $\mathbf{0}$ & $\mathbf{0}$ & $\mathbf{0}$ & $1(0.91 \%)$ \\
\hline 8 & - & - & - & - & - \\
\hline Total & 107 (98.12\%) & $107(100 \%)$ & $109(100 \%)$ & $107(98.12 \%)$ & $107(98.12 \%)$ \\
\hline
\end{tabular}

OBS:Faleceram dois pacientes entre o $3^{\circ}$ e $4^{\circ}$ exames e estes foram considerados como não computado pc motivo a soma nos outros campos é de 107 pacientes. 
Tabela n²8: Distribuição do número de pacientes pelo tipo de prótese na maxila e mandíbula.

\begin{tabular}{|c|c|c|c|}
\hline & \multicolumn{3}{|c|}{ Número de pacientes } \\
\hline Tipo de prótese & Maxila & Mandíbula & Total \\
\hline A-Elemento unitário sup. impl. & 17 & 8 & 25 \\
\hline B-Sobre-dentadura sup. impl. & 4 & 16 & 20 \\
\hline C-Protocolo sup. impl. & 6 & $2 \mathbf{2 1}$ & 27 \\
\hline D-Parcial com 2 elementos sup. Impl. & 5 & 32 & 37 \\
\hline E-Parcial com 3 elementos sup. Impl. & $\overline{7}$ & 17 & 24 \\
\hline F-Parcial com 4 elementos sup. Impl. & $\mathbf{1}$ & $\mathbf{1}$ & 2 \\
\hline G-Dente natural & 56 & 62 & 118 \\
\hline H-Prótese convencional & $\mathbf{1 1}$ & 7 & 18 \\
\hline I-Prótese total & 35 & $\mathbf{1}$ & 36 \\
\hline J-Suportada por implante em andamento & 10 & 9 & 19 \\
\hline L-Prótese removivel & $\overline{1}$ & 3 & 4 \\
\hline
\end{tabular}

OBS:A abreviatura "sup. impl." significa - "suportada por implante".

Durante os exames foi registrado o tipo de reabilitação protética suportada por implante ou convencional na arcada monitorada, como também o tipo do arco antagonista.

Tabela $\mathbf{n}^{\circ 29}$ :Número de pacientes com inflamação do tecido gengival peri-implantar maxila nos quatro exames.

Número de pacientes

\begin{tabular}{l|c|c|c|c|c}
\hline & Índice 0 & Indice 1 & Indice 2 & Indice 3 & Total \\
\hline $1^{\circ}$ exame & $102(93.57 \%)$ & $3(2.75 \%)$ & $3(2.75 \%)$ & $1(0.91 \%)$ & $109(100 \%)$ \\
\hline $2^{\circ}$ exame & $99(96.12 \%)$ & $2(1.94 \%)$ & $2(1.94 \%)$ & 0 & $103(100 \%)$ \\
\hline $3^{\circ}$ exame & $94(94.95 \%)$ & $2(2.02 \%)$ & $3(3.03 \%)$ & 0 & $99(100 \%)$ \\
\hline $4^{\circ}$ exame & $\mathbf{8 8}(98.88 \%)$ & $1(1.12 \%)$ & 0 & 0 & $89(100 \%)$ \\
\hline
\end{tabular}

O índice zero corresponde a ausência de inflamação, 1 inflamação leve, 2 moderada e 3 severa 
Tabela n³0:Número de pacientes com inflamação do tecido gengival peri-implantar na mandíbula nos quatro exames.

\begin{tabular}{|c|c|c|c|c|c|}
\hline & \multicolumn{5}{|c|}{ Número de pacientes } \\
\hline & Indice 0 & Indice 1 & Indice 2 & Indice 3 & Total \\
\hline $1^{\circ}$ exame & $101(92.67 \%)$ & 4 (3.67\%) & $3(2.75 \%)$ & $1(0.91 \%)$ & 109 (100\%) \\
\hline $2^{\circ}$ exame & $97(94.18 \%)$ & $5(4.85 \%)$ & $1(0.97 \%)$ & $\mathbf{0}$ & $103(94.48 \%)$ \\
\hline $3^{\circ}$ exame & $95(95.96 \%)$ & 1 (1.01\%) & $2(2.02 \%)$ & 1 (1.01\%) & $99(90.81 \%)$ \\
\hline $4^{\circ}$ exame & $88(98.88 \%)$ & $\mathbf{0}$ & $\mathbf{0}$ & 1 (1.12\%) & $89(81.65 \%)$ \\
\hline
\end{tabular}

O índice zero corresponde a ausência de inflamação, 1 inflamação leve, 2 moderada e 3 severa.

Tabela $\mathbf{n}^{\circ}$ 31:Número de fraturas da infra-estrutura da prótese durante os quatro exames na maxila.

\begin{tabular}{l|c|c|c}
\hline & \multicolumn{3}{|c}{ Número de pacientes } \\
\hline & Índice 0 & Indice 1 & Total \\
\hline $1^{\circ}$ exame & $109(100 \%)$ & 0 & $109(100 \%)$ \\
\hline $2^{\circ}$ exame & $103(100 \%)$ & 0 & $103(100 \%)$ \\
\hline $3^{\circ}$ exame & $99(100 \%)$ & 0 & $99(100 \%)$ \\
\hline $4^{\circ}$ exame & $\mathbf{8 8 ( 9 8 . 8 8 \% )}$ & $1(1.12 \%)$ & $\mathbf{8 9 ( 8 1 . 6 4 \% )}$ \\
\hline
\end{tabular}

$O$ indice 0 corresponde ausente e 1 presente. Registrou-se fratura da infraestrutura em uma prótese tipo protocolo superior. Suspeitou-se de hábito parafuncional, pois esta paciente no primeiro exame fraturou a porcelana do canino, e no quarto exame a paciente relatou que atravessava fase de estresse acentuado. A prótese foi novamente confeccionada e instalada. 
Tabela $\mathbf{n}^{\circ}$ 32: Número de fraturas da infra-estrutura da prótese durante os quatro exames na mandíbula.

\begin{tabular}{l|c|c|c}
\hline \multicolumn{3}{c}{ Número de pacientes } \\
\hline & Indice 0 & Índice 1 & Total \\
\hline $1^{\circ}$ exame & $109(100 \%)$ & 0 & $109(100 \%)$ \\
\hline $2^{\circ}$ exame & $103(100 \%)$ & 0 & $103(100 \%)$ \\
\hline $3^{\circ}$ exame & $99(100 \%)$ & 0 & $99(100 \%)$ \\
\hline $4^{\circ}$ exame & $\mathbf{8 9 ( 1 0 0 \% )}$ & 0 & $89(100 \%)$ \\
\hline
\end{tabular}

$\mathrm{O}$ indice 0 corresponde ausente e 1 presente.

Tabela $\mathbf{n}^{\circ}$ 33:Número de parafusos do intermediário fraturados nos quatro exames na maxila.

\begin{tabular}{|c|c|c|c|c|c|}
\hline & \multicolumn{5}{|c|}{ Número de pacientes } \\
\hline & Indice 0 & Indice 1 & Indice 2 & Indice 3 & Total \\
\hline $1^{\circ}$ exame & $109(100 \%)$ & $\mathbf{0}$ & $\mathbf{0}$ & $\mathbf{0}$ & $109(100 \%)$ \\
\hline $2^{\circ}$ exame & $103(100 \%)$ & $\mathbf{0}$ & $\mathbf{0}$ & $\mathbf{0}$ & $103(100 \%)$ \\
\hline $3^{\circ}$ exame & 99 (100\%) & $\mathbf{0}$ & $\mathbf{0}$ & $\mathbf{0}$ & 99 (100\%) \\
\hline $4^{\circ}$ exame & 89 (100\%) & $\mathbf{0}$ & $\mathbf{0}$ & $\mathbf{0}$ & $89(100 \%)$ \\
\hline
\end{tabular}

$\mathrm{O}$ índice zero equivale a ausente e os subsequentes ao número de parafusos fraturados.

Tabela $\mathbf{n}^{\circ}$ 34: Número de parafusos do intermediário fraturados nos quatro exames na mandibula.

Número de pacientes

\begin{tabular}{l|c|c|c|c|c}
\hline & Indice 0 & Indice 1 & Indice 2 & Indice 3 & Total \\
\hline $1^{\circ}$ exame & $108(99.09 \%)$ & 0 & 0 & $1(0.91 \%)$ & $109(100 \%)$ \\
\hline $2^{\circ}$ exame & $102(99.03 \%)$ & 0 & $1(0.97 \%)$ & 0 & $103(100 \%)$ \\
\hline $3^{\circ}$ exame & $97(97.98 \%)$ & $1(1.01 \%)$ & $1(1.01 \%)$ & 0 & $99(100 \%)$ \\
\hline $4^{\circ}$ exame & $89(100 \%)$ & 0 & 0 & 0 & $89(100 \%)$ \\
\hline
\end{tabular}

O índice zero equivale a ausente e os subsequentes ao número de parafusos

fraturados. A fratura de parafusos do intermediário se concentrou em poucos pacientes, e geralmente associado a fraturas do parafuso da prótese, em períodos de estresse acentuado 
Tabela $\mathbf{n}^{\circ}$ 35: Número de parafusos da prótese fraturados na maxila, nos quatro exames.

Número de pacientes

\begin{tabular}{l|c|c|c|c|c}
\hline & Indice 0 & Indice 1 & Indice 2 & Indice 3 & Total \\
\hline $1^{\circ}$ exame & $108(99.09 \%)$ & $1(091 \%)$ & 0 & 0 & $109(100 \%)$ \\
\hline $2^{\circ}$ exame & $103(100 \%)$ & 0 & 0 & 0 & $103(100 \%)$ \\
\hline $3^{\circ}$ exame & $98(98.99 \%)$ & 0 & $1(1.01 \%)$ & 0 & $99(100 \%)$ \\
\hline $4^{\circ}$ exame & $89(100 \%)$ & 0 & 0 & 0 & $89(100 \%)$ \\
\hline
\end{tabular}

$\mathrm{O}$ índice zero equivale a ausente e os subsequentes ao número de parafusos fraturados.

Tabela $\mathbf{n}^{\circ}$ 36:Número de parafusos da prótese fraturados na mandíbula, nos quatro exames.

\begin{tabular}{l|c|c|c|c|c|c|c}
\hline \multicolumn{7}{c}{ Número de pacientes } \\
\hline & 0 & 1 & 2 & 3 & 4 & 5 & Total \\
\hline $1^{\circ}$ exame & $107(98.18 \%)$ & 0 & $1(0.91 \%)$ & 0 & $1(0.91 \%)$ & 0 & $109(100 \%)$ \\
\hline $2^{\circ}$ exame & $99(96.12 \%)$ & 0 & $1(0.97 \%)$ & $2(1.94 \%)$ & 0 & $1(0.97 \%)$ & $103(100 \%)$ \\
\hline $3^{\circ}$ exame & $95(95.95 \%)$ & $1(1.01 \%)$ & 0 & 0 & 0 & $3(3.03 \%)$ & $99(100 \%)$ \\
\hline $4^{\circ}$ exame & $\mathbf{8 6}(96.64 \%)$ & $\mathbf{2}(2.24 \%)$ & 0 & $1(1.12 \%)$ & 0 & 0 & $89(100 \%)$ \\
\hline
\end{tabular}

O índice zero equivale a ausente e os subsequentes ao número de parafusos

fraturados. A fratura de parafusos da prótese se concentrou em poucos pacientes e em alguns com mais de um evento. Investigou-se a causa e se necessário recomendou-se uso de placa miorrelaxante, a fim de controlar hábitos parafuncionais. 
Tabela $\mathbf{n}^{\circ} \mathbf{3 7}$ :Fratura do clipe da sobre-dentadura instalada na maxila nos quatro exames.

\begin{tabular}{l|c|c|c}
\hline \multicolumn{4}{c}{ Número de pacientes } \\
\hline & Indice 0 & Indice 1 & Total \\
\hline $1^{\circ}$ exame & $109(100 \%)$ & 0 & $109(100 \%)$ \\
\hline $2^{\circ}$ exame & $103(100 \%)$ & 0 & $103(100 \%)$ \\
\hline $3^{\circ}$ exame & $99(100 \%)$ & 0 & $99(100 \%)$ \\
\hline $4^{\circ}$ exame & $89(100 \%)$ & 0 & $89(100 \%)$ \\
\hline
\end{tabular}

$\mathrm{O}$ índice 0 equivale a ausente e o 1 presente.

Tabela $\mathbf{n}^{\circ}$ 38: Fratura do clipe da sobre-dentadura na mandíbula nos quatro exames.

\begin{tabular}{l|c|c|c}
\hline \multicolumn{4}{c}{ Número de pacientes } \\
\hline & Indice 0 & Indice 1 & Total \\
\hline $1^{\circ}$ exame & $109(100 \%)$ & 0 & $109(100 \%)$ \\
\hline $2^{\circ}$ exame & $99(96.12 \%)$ & $4(3.88 \%)$ & $103(100 \%)$ \\
\hline $3^{\circ}$ exame & $97(97.98 \%)$ & $2(2.02 \%)$ & $99(100 \%)$ \\
\hline $4^{\circ}$ exame & $\mathbf{8 9}(100 \%)$ & 0 & $89(100 \%)$ \\
\hline
\end{tabular}

$\mathrm{O}$ índice 0 equivale a ausente e o 1 presente.

Tabela $\mathbf{n}^{\circ}$ 39:Fratura da prótese total na mandíbula, após instalação da sobre-dentadura na maxila.

\begin{tabular}{l|c|c|c}
\hline \multicolumn{4}{c}{ Número de pacientes } \\
\hline & Indice 0 & Indice 1 & Total \\
\hline $1^{\circ}$ exame & $109(\mathbf{1 0 0 \% )}$ & $\mathbf{0}$ & $\mathbf{1 0 9 ( 1 0 0 \% )}$ \\
\hline $\mathbf{2}^{\circ}$ exame & $\mathbf{1 0 3 ( 1 0 0 \% )}$ & $\mathbf{0}$ & $\mathbf{1 0 3 ( 1 0 0 \% )}$ \\
\hline $3^{\circ}$ exame & $\mathbf{9 9 ( 1 0 0 \% )}$ & $\mathbf{0}$ & $\mathbf{9 9 ( 1 0 0 \% )}$ \\
\hline $4^{\circ}$ exame & $\mathbf{8 9 ( 1 0 0 \% )}$ & $\mathbf{0}$ & $\mathbf{8 9 ( 1 0 0 \% )}$ \\
\hline O zero indica ausente e o 1 presente
\end{tabular}


Tabela $\mathbf{n}^{\circ}$ 40:Fratura da prótese total na maxila, após instalação de sobre-dentadura na mandíbula.

\begin{tabular}{l|c|c|c}
\hline \multicolumn{4}{c}{ Número de pacientes } \\
\hline & Indice 0 & Indice 1 & Total \\
\hline $\mathbf{1}^{\circ}$ exame & $\mathbf{1 0 5}(\mathbf{9 6 . 4 4 \% )}$ & $\mathbf{4}(\mathbf{3 . 6 6 \% )}$ & $\mathbf{1 0 9 ( 1 0 0 \% )}$ \\
\hline $\mathbf{2}^{\circ}$ exame & $\mathbf{1 0 3 ( 1 0 0 \% )}$ & $\mathbf{0}$ & $\mathbf{1 0 3 ( 1 0 0 \% )}$ \\
\hline $\mathbf{3}^{\circ}$ exame & $\mathbf{9 8 ( 9 8 . 9 8 \% )}$ & $\mathbf{1}(\mathbf{1 . 0 2 )}$ & $\mathbf{9 9 ( 1 0 0 \% )}$ \\
\hline $4^{\circ}$ exame & $\mathbf{8 9 ( 1 0 0 \% )}$ & $\mathbf{0}$ & $\mathbf{8 9 ( 1 0 0 \% )}$ \\
\hline O zero indica ausente e o 1 presente.
\end{tabular}

Tabela $\mathbf{n}^{\circ}$ 41: Fratura da prótese total na mandíbula, após instalação de prótese protocolo na maxila.

\begin{tabular}{l|c|c|c}
\hline \multicolumn{4}{c}{ Número de pacientes } \\
\hline & Indice 0 & Índice 1 & Total \\
\hline $1^{\circ}$ exame & $\mathbf{1 0 9 ( 1 0 0 \% )}$ & $\mathbf{0}$ & $\mathbf{1 0 9 ( 1 0 0 \% )}$ \\
\hline $\mathbf{2}^{\circ}$ exame & $\mathbf{1 0 3 ( 1 0 0 \% )}$ & $\mathbf{0}$ & $\mathbf{1 0 3 ( 1 0 0 \% )}$ \\
\hline $3^{\circ}$ exame & $\mathbf{9 9 ( 1 0 0 \% )}$ & $\mathbf{0}$ & $\mathbf{9 9 ( 1 0 0 \% )}$ \\
\hline $4^{\circ}$ exame & $\mathbf{8 9 ( 1 0 0 \% )}$ & $\mathbf{0}$ & $\mathbf{8 9 ( 1 0 0 \% )}$ \\
\hline O zero indica ausente e o 1 presente.
\end{tabular}

Tabela $\mathbf{n}^{\circ}$ 42: Fratura da prótese total na maxila, após instalação de prótese protocolo na mandíbula.

\begin{tabular}{l|c|c|c}
\hline \multicolumn{4}{c}{ Número de pacientes } \\
\hline & Indice 0 & Índice 1 & Total \\
\hline $1^{\circ}$ exame & $108(98.17 \%)$ & $2(1.83 \%)$ & $109(100 \%)$ \\
\hline $2^{\circ}$ exame & $102(99.02 \%)$ & $1(0.97 \%)$ & $103(100 \%)$ \\
\hline $3^{\circ}$ exame & $\mathbf{9 8}(98.99 \%)$ & $1(1.01 \%)$ & $99(100 \%)$ \\
\hline $4^{\circ}$ exame & $\mathbf{8 9}(100 \%)$ & 0 & $89(100 \%)$ \\
\hline
\end{tabular}

O zero indica ausente e o 1 presente. 
Tabela n43: Distribuição da presença ou ausência de mobilidade da prótese sobre implante na maxila.

\begin{tabular}{l|c|c|c}
\hline \multicolumn{4}{c}{ Número de pacientes } \\
\hline & Indice 0 & Indice 1 & Total \\
\hline $1^{\circ}$ exame & $105(96.33 \%)$ & $4(3.67 \%)$ & $109(100 \%)$ \\
\hline $2^{\circ}$ exame & $103(100 \%)$ & 0 & $103(100 \%)$ \\
\hline $3^{\circ}$ exame & $96(96.97 \%)$ & $3(3.03 \%)$ & $99(100 \%)$ \\
\hline $4^{\circ}$ exame & $\mathbf{8 7}(97.76 \%)$ & $2(2.24 \%)$ & $89(100 \%)$ \\
\hline
\end{tabular}

A presença de mobilidade corresponde ao índice 1 e a ausência pelo índice 0 .

Tabela $\mathbf{n}^{\circ}$ 44: Distribuição da presença ou ausência de mobilidade da prótese sobre implante na mandíbula.

\begin{tabular}{l|c|c|c}
\hline \multicolumn{4}{c}{ Número de pacientes } \\
\hline & Indice 0 & Índice 1 & Total \\
\hline $1^{\circ}$ exame & $96(88.06 \%)$ & $13(11.92 \%)$ & $109(100 \%)$ \\
\hline $2^{\circ}$ exame & $91(88.35 \%)$ & $12(11.65 \%)$ & $103(100 \%)$ \\
\hline $3^{\circ}$ exame & $97(97.98 \%)$ & $2(2.02 \%)$ & $99(100 \%)$ \\
\hline $4^{\circ}$ exame & $89(100 \%)$ & 0 & $89(100 \%)$ \\
\hline
\end{tabular}

A presença de mobilidade corresponde ao índice 1 e a ausência pelo índice 0 . Nos primeiros dois exames a mobilidade da prótese se relacionou ao afrouxamento dos parafusos da prótese.

Tabela $\mathbf{n}^{\circ}$ 45: Alteração na fonação, depois da instalação da prótese sobre implante na maxila.

\begin{tabular}{l|c|c|c}
\hline \multicolumn{4}{c}{ Número de pacientes } \\
\hline & Índice 0 & Índice 1 & Total \\
\hline $1^{\circ}$ exame & $105(96.33 \%)$ & $4(3.67 \%)$ & $109(100 \%)$ \\
\hline $2^{\circ}$ exame & $103(100 \%)$ & 0 & $103(100 \%)$ \\
\hline $3^{\circ}$ exame & $99(100 \%)$ & 0 & $99(100 \%)$ \\
\hline $4^{\circ}$ exame & $\mathbf{8 9 ( 1 0 0 \% )}$ & 0 & $89(100 \%)$ \\
\hline
\end{tabular}

A presença de alteração na fonação corresponde ao índice 1 e a ausência pelo índice 0 . 
Tabela $\mathbf{n}^{\circ}$ 46: Alteração na fonação, depois da instalação da prótese sobre implante na mandibula.

\begin{tabular}{l|c|c|c}
\hline \multicolumn{4}{c}{ Número de pacientes } \\
\hline & Índice 0 & Índice 1 & Total \\
\hline $1^{\circ}$ exame & $105(96.33 \%)$ & $4(3.67 \%)$ & $109(100 \%)$ \\
\hline $2^{\circ}$ exame & $103(100 \%)$ & 0 & $103(100 \%)$ \\
\hline $3^{\circ}$ exame & $99(100 \%)$ & 0 & $99(100 \%)$ \\
\hline $4^{\circ}$ exame & $\mathbf{8 9 ( 1 0 0 \% )}$ & 0 & $89(100 \%)$ \\
\hline
\end{tabular}

$\overline{\text { A presença de alteração na fonação corresponde ao índice }} 1$ e a ausência pelo índice 0 .

Tabela n47:Presença de sintomatologia dolorosa depois da instalação da prótese sobre implante na maxila.

\begin{tabular}{l|c|c|c}
\hline \multicolumn{4}{|c}{ Número de pacientes } \\
\hline & Indice 0 & Indice 1 & Total \\
\hline $1^{\circ}$ exame & $109(100 \%)$ & 0 & $109(100 \%)$ \\
\hline $2^{\circ}$ exame & $103(100 \%)$ & 0 & $103(100 \%)$ \\
\hline $3^{\circ}$ exame & $99(100 \%)$ & 0 & $99(100 \%)$ \\
\hline $4^{\circ}$ exame & $89(100 \%)$ & 0 & $89(100 \%)$ \\
\hline
\end{tabular}

A presença de sintomatologia dolorosa corresponde ao índice 1 e a ausência ao índice 0 . 
Tabela $\mathbf{n}^{\circ}$ 48: Presença de sintomatologia dolorosa depois da instalação da prótese sobre implante na mandíbula.

\begin{tabular}{l|c|c|c}
\hline \multicolumn{4}{c}{ Número de pacientes } \\
\hline & Indice 0 & Indice 1 & Total \\
\hline $1^{\circ}$ exame & $108(99.08 \%)$ & $1(0.91 \%)$ & $109(100 \%)$ \\
\hline $2^{\circ}$ exame & $102(99.03 \%)$ & $1(0.97 \%)$ & $103(100 \%)$ \\
\hline $3^{\circ}$ exame & $99(100 \%)$ & 0 & $99(100 \%)$ \\
\hline $4^{\circ}$ exame & $89(100 \%)$ & 0 & $89(100 \%)$ \\
\hline
\end{tabular}

A presença de sintomatologia dolorosa corresponde ao índice 1 e a ausência ao índice 0 . Nos dois primeiros exames uma paciente se queixou de dor em toda a área do implante, entretanto aspecto clínico e radiográfico não se apresentaram compatíveis com a sintomatologia da paciente. Nos exames subsequentes a dor havia desaparecido.

Tabela $\mathbf{n}^{\circ}$ 49:Presença de parestesia depois da instalação da prótese sobre implante na maxila.

\begin{tabular}{l|c|c|c}
\hline \multicolumn{4}{|c}{ Número de pacientes } \\
\hline & Indice 0 & Índice 1 & Total \\
\hline $1^{\circ}$ exame & $109(100 \%)$ & 0 & $109(100 \%)$ \\
\hline $2^{\circ}$ exame & $103(100 \%)$ & 0 & $103(100 \%)$ \\
\hline $3^{\circ}$ exame & $99(100 \%)$ & 0 & $99(100 \%)$ \\
\hline $4^{\circ}$ exame & $\mathbf{8 9 ( 1 0 0 \% )}$ & 0 & $89(100 \%)$ \\
\hline
\end{tabular}

A presença de parestesia corresponde ao índice 1 e a ausência ao índice 0. 
Tabela $\mathbf{n}^{\circ 50}$ :Presença de parestesia depois da instalação da prótese sobre implante na mandíbula.

\begin{tabular}{c|c|c|c}
\hline \multicolumn{4}{c}{ Número de pacientes } \\
\hline & Índice 0 & İndice 1 & Total \\
\hline $1^{\circ}$ exame & $105(96.44 \%)$ & $4(3.66 \%)$ & $109(100 \%)$ \\
\hline $2^{\circ}$ exame & $101(98.06 \%)$ & $2(1.94 \%)$ & $103(100 \%)$ \\
\hline $3^{\circ}$ exame & $97(97.98 \%)$ & $2(2.02 \%)$ & $99(100 \%)$ \\
\hline $4^{\circ}$ exame & $\mathbf{8 7}(97.76 \%)$ & $2(2.24 \%)$ & $89(100 \%)$ \\
\hline
\end{tabular}

A presença de parestesia corresponde ao índice 1 e a ausência ao índice 0 .

No primeiro exame registrou-se $3.66 \%$ dos pacientes com parestesia, sendo que com 6 meses em apenas metade persistiu o problema com 1.94\%. Estes pacientes relataram até o final do estudo recuperação de grande parte da área comprometida pela parestesia.

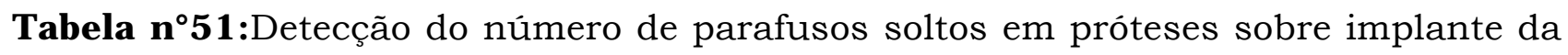
maxila necessitando de reapertamento.

\begin{tabular}{l|c|c|c|c|c|c|c}
\hline \multicolumn{7}{c}{ Número de pacientes } \\
\hline & 0 & 1 & 2 & 3 & 4 & 5 & Total \\
\hline $1^{\circ}$ exame & $105(96.36 \%)$ & 0 & $1(0.91 \%)$ & $1(0.91 \%)$ & $1(0.91 \%)$ & $1(0.91 \%)$ & $109(100 \%)$ \\
\hline $2^{\circ}$ exame & $103(100 \%)$ & 0 & 0 & 0 & 0 & 0 & $103(100 \%)$ \\
\hline $3^{\circ}$ exame & $98(98.99 \%)$ & 0 & $1(1.01 \%)$ & 0 & 0 & 0 & $99(100 \%)$ \\
\hline $4^{\circ}$ exame & $89(100 \%)$ & 0 & 0 & 0 & 0 & 0 & $89(100 \%)$ \\
\hline
\end{tabular}

O índice 0 corresponde a ausência desta complicação e os números subsequentes ao número de parafusos reapertados. Houve detecção mais acentuada de parafusos frouxos no primeiro exame e estabilização do aperto dos parafusos nos outros exames na maxila. 
Tabela n52:Detecção do número de parafusos soltos em próteses sobre implante da mandibula necessitando de reapertamento.

Número de pacientes

\begin{tabular}{l|c|c|c|c|c|c|l}
\hline & 0 & 1 & 2 & 3 & 4 & 5 & \multicolumn{1}{|c|}{ Total } \\
\hline $1^{\circ}$ exame & $93(85.35 \%)$ & $3(2.75 \%)$ & $8(7.33 \%)$ & $4(3.66 \%)$ & 0 & $1(0.91 \%)$ & $109(100 \%)$ \\
\hline $2^{\circ}$ exame & $97(94.17 \%)$ & $2(1.94 \%)$ & $4(3.88 \%)$ & 0 & 0 & 0 & $103(100 \%)$ \\
\hline $3^{\circ}$ exame & $94(94.94 \%)$ & $2(2.02 \%)$ & $2(2.02 \%)$ & 0 & 0 & $1(1.01 \%)$ & $99(100 \%)$ \\
\hline $4^{\circ}$ exame & $88(98.88 \%)$ & $1(1 \%)$ & 0 & 0 & 0 & 0 & $89(100 \%)$ \\
\hline
\end{tabular}

O índice 0 corresponde a ausência desta complicação e os números subsequentes ao número de parafusos reapertados. Houve detecção mais acentuada na no primeiro exame, contudo reduziu-se gradativamente até o quarto exame com a estabilização dos parafusos da prótese.

Tabela $\mathbf{n}^{\circ}$ 53:Registro do número de intermediários na maxila que necessitaram de torque, por se apresentarem soltos

\begin{tabular}{|c|c|c|c|c|c|c|c|}
\hline & \multicolumn{7}{|c|}{ Número de pacientes } \\
\hline & $\overline{\mathbf{0}}$ & $\mathbf{1}$ & $\overline{2}$ & $\overline{3}$ & 4 & $\overline{5}$ & Total \\
\hline $1^{\circ}$ exame & 108 (99.09\%) & $1(0.91 \%)$ & $\mathbf{0}$ & $\mathbf{0}$ & $\mathbf{0}$ & $\mathbf{0}$ & $109(100 \%)$ \\
\hline $2^{\circ}$ exame & 103 (100\%) & $\mathbf{0}$ & $\mathbf{0}$ & $\mathbf{0}$ & $\mathbf{0}$ & $\mathbf{0}$ & $103(100 \%)$ \\
\hline $3^{\circ}$ exame & $98(98.98 \%)$ & $\mathbf{0}$ & 1 (1.01\%) & $\mathbf{0}$ & $\mathbf{0}$ & $\mathbf{0}$ & 99 (100\%) \\
\hline $4^{\circ}$ exame & 89 (100\%) & $\mathbf{0}$ & $\mathbf{0}$ & $\mathbf{0}$ & $\mathbf{0}$ & $\mathbf{0}$ & $89(100 \%)$ \\
\hline
\end{tabular}

O índice 0 equivale a ausência de intermediários necessitando de torque e os números seguintes aos intermediários submetidos a torque. 
Tabela $\mathbf{n}^{\circ 54}$ :Registro do número de intermediários na mandíbula que necessitaram de torque por se apresentarem soltos

Número de pacientes

\begin{tabular}{l|c|c|c|c|c|c|l}
\hline & 0 & 1 & 2 & 3 & 4 & 5 & \multicolumn{1}{|c}{ Total } \\
\hline $1^{\circ}$ exame & $102(93.6 \%)$ & $2(1.83 \%)$ & $4(3.66 \%)$ & 0 & 0 & $1(0.91 \%)$ & $109(100 \%)$ \\
\hline $2^{\circ}$ exame & $98(95.15 \%)$ & $1(0.97 \%)$ & $3(2.91 \%)$ & 0 & 0 & $1(0.91 \%)$ & $103(100 \%)$ \\
\hline $3^{\circ}$ exame & $94(94.95 \%)$ & $2(2.02 \%)$ & 0 & 0 & $1(1.01 \%)$ & $2(2.02 \%)$ & $99(100 \%)$ \\
\hline $4^{\circ}$ exame & $89(100 \%)$ & 0 & 0 & 0 & 0 & 0 & $89(100 \%)$ \\
\hline
\end{tabular}

O índice 0 equivale a ausência de intermediários necessitando de torque e os números seguintes aos intermediários submetidos a torque

Tabela $\mathbf{n}^{\circ}$ 55:Presença de desconforto muscular, depois da instalação da prótese sobre implante na maxila

\begin{tabular}{l|c|c|c}
\hline \multicolumn{4}{c}{ Número de pacientes } \\
\hline & Indice 0 & Indice 1 & Total \\
\hline $1^{\circ}$ exame & $108(99.09 \%)$ & $1(0.91 \%)$ & $109(100 \%)$ \\
\hline $2^{\circ}$ exame & $103(100 \%)$ & 0 & $103(100 \%)$ \\
\hline $3^{\circ}$ exame & $99(100 \%)$ & 0 & $99(100 \%)$ \\
\hline $4^{\circ}$ exame & $\mathbf{8 9 ( 1 0 0 \% )}$ & 0 & $89(100 \%)$ \\
\hline
\end{tabular}

O índice 0 equivale a ausência de desconforto muscular e o 1 a presença.

Tabela $\mathbf{n}^{\circ}$ 56:Presença de desconforto muscular, depois da instalação da prótese sobre implante na mandíbula

\begin{tabular}{l|c|c|c}
\hline \multicolumn{4}{|c}{ Número de pacientes } \\
\hline & Indice 0 & Indice 1 & Total \\
\hline $1^{\circ}$ exame & $105(96.44 \%)$ & $4(3.66 \%)$ & $109(100 \%)$ \\
\hline $2^{\circ}$ exame & $103(100 \%)$ & 0 & $103(100 \%)$ \\
\hline $3^{\circ}$ exame & $99(100 \%)$ & 0 & $99(100 \%)$ \\
\hline $4^{\circ}$ exame & $89(100 \%)$ & 0 & $89(100 \%)$ \\
\hline
\end{tabular}

O índice 0 equivale a ausência de desconforto muscular e o 1 a presença. 
Tabela $\mathbf{n}^{\circ} \mathbf{5 7}$ : Detecção de dor na ATM, após a instalação da prótese na maxila

\begin{tabular}{l|c|c|c}
\hline \multicolumn{4}{|c}{ Número de pacientes } \\
\hline & Índice 0 & Índice 1 & Total \\
\hline $1^{\circ}$ exame & $108(99.09 \%)$ & $1(0.91 \%)$ & $109(100 \%)$ \\
\hline $2^{\circ}$ exame & $103(100 \%)$ & 0 & $103(100 \%)$ \\
\hline $3^{\circ}$ exame & $99(100 \%)$ & 0 & $99(100 \%)$ \\
\hline $4^{\circ}$ exame & $89(100 \%)$ & 0 & $89(100 \%)$ \\
\hline
\end{tabular}

A presença de dor na ATM corresponde ao índice 1 e zero para ausência.

Tabela n58: Detecção de dor na ATM, após a instalação da prótese na mandíbula,

\begin{tabular}{l|c|c|c}
\hline \multicolumn{4}{c}{ Número de pacientes } \\
\hline & Indice 0 & Indice 1 & Total \\
\hline $1^{\circ}$ exame & $107(98.27 \%)$ & $\mathbf{2}(1.83 \%)$ & $109(100 \%)$ \\
\hline $2^{\circ}$ exame & $103(100 \%)$ & 0 & $103(100 \%)$ \\
\hline $3^{\circ}$ exame & $99(100 \%)$ & 0 & $99(100 \%)$ \\
\hline $4^{\circ}$ exame & $\mathbf{8 9 ( 1 0 0 \% )}$ & 0 & $\mathbf{8 9 ( 1 0 0 \% )}$ \\
\hline
\end{tabular}

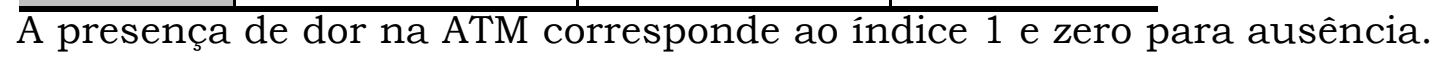

Tabela $\mathbf{n}^{\circ}$ 59: Necessidade de reembasamento da sobre-dentadura da maxila

\begin{tabular}{l|c|c|c}
\hline \multicolumn{4}{c}{ Número de pacientes } \\
\hline & Indice 0 & Índice 1 & Total \\
\hline $1^{\circ}$ exame & $107(98.17 \%)$ & $2(1.83 \%)$ & $109(100 \%)$ \\
\hline $2^{\circ}$ exame & $103(100 \%)$ & 0 & $103(100 \%)$ \\
\hline $3^{\circ}$ exame & $99(100 \%)$ & 0 & $99(100 \%)$ \\
\hline $4^{\circ}$ exame & $\mathbf{8 9 ( 1 0 0 \% )}$ & 0 & $89(100 \%)$ \\
\hline
\end{tabular}

Se houve necessidade de reembasamento corresponde ao indice 1 e zero se for ausente. 
Tabela $\mathbf{n}^{\circ}$ 60: Necessidade de reembasamento da sobre-dentadura da mandíbula

\begin{tabular}{l|c|c|c}
\hline \multicolumn{4}{|c}{ Número de pacientes } \\
\hline & Indice 0 & Indice 1 & Total \\
\hline $1^{\circ}$ exame & $108(99.09 \%)$ & $1(0.91 \%)$ & $109(100 \%)$ \\
\hline $2^{\circ}$ exame & $103(100 \%)$ & 0 & $103(100 \%)$ \\
\hline $3^{\circ}$ exame & $99(100 \%)$ & 0 & $99(100 \%)$ \\
\hline $4^{\circ}$ exame & $89(100 \%)$ & 0 & $89(100 \%)$ \\
\hline
\end{tabular}

Se houve necessidade de reembasamento corresponde ao índice 1 e zero se for ausente.

Tabela $\mathbf{n}^{\circ}$ 61: Detecção do número de parafusos na prótese sobre implante da maxila, espanados ou com desgaste no encaixe, necessitando de troca

\section{Número de parafusos}

\begin{tabular}{l|c|c|c|c|c|c|l}
\hline & $\mathbf{0}$ & $\mathbf{1}$ & $\mathbf{2}$ & $\mathbf{3}$ & $\mathbf{4}$ & 5 & \multicolumn{1}{c}{ Total } \\
\hline $\mathbf{1}^{\circ}$ exame & $\mathbf{1 0 8}(\mathbf{9 9 . 0 9 \% )}$ & $\mathbf{1}(\mathbf{0 . 9 1 \% )}$ & $\mathbf{0}$ & $\mathbf{0}$ & $\mathbf{0}$ & $\mathbf{0}$ & $\mathbf{1 0 9 ( 1 0 0 \% )}$ \\
\hline $2^{\circ}$ exame & $103(100 \%)$ & 0 & 0 & 0 & 0 & 0 & $103(100 \%)$ \\
\hline $3^{\circ}$ exame & $99(100 \%)$ & 0 & 0 & 0 & 0 & 0 & $99(100 \%)$ \\
\hline $4^{\circ}$ exame & $\mathbf{8 9}(100 \%)$ & 0 & 0 & 0 & 0 & 0 & $89(100 \%)$ \\
\hline
\end{tabular}

O índice 0 correspondeu a ausência de parafusos da prótese espanados ou com desgaste no encaixe, e os algarismos seguintes ao número de parafusos.

Tabela n62: Detecção do número de parafusos na prótese sobre implante da maxila, espanados ou com desgaste no encaixe, necessitando de troca

\section{Número de pacientes}

\begin{tabular}{l|c|c|c|c|c|c|l}
\hline & 0 & 1 & 2 & 3 & 4 & 5 & \multicolumn{1}{|c|}{ Total } \\
\hline $1^{\circ}$ exame & $103(94.48 \%)$ & $4(3.66 \%)$ & $2(1.83 \%)$ & 0 & 0 & 0 & $109(100 \%)$ \\
\hline $2^{\circ}$ exame & $103(100 \%)$ & 0 & 0 & 0 & 0 & 0 & $103(100 \%)$ \\
\hline $3^{\circ}$ exame & $98(98.99 \%)$ & $1(1.01 \%)$ & 0 & 0 & 0 & 0 & $99(100 \%)$ \\
\hline $4^{\circ}$ exame & $89(100 \%)$ & 0 & 0 & 0 & 0 & 0 & $89(100 \%)$ \\
\hline
\end{tabular}

O índice 0 correspondeu a ausência de parafusos da prótese espanados ou

com desgaste no encaixe, e os algarismos seguintes ao número de parafusos 
Tabela $\mathbf{n}^{\circ}$ 63:Presença de desgaste na porcelana da prótese da maxila

\begin{tabular}{|c|c|c|c|c|c|}
\hline & \multicolumn{5}{|c|}{ Número de pacientes } \\
\hline & $\overline{\mathbf{0}}$ & $\overline{\mathbf{1}}$ & $\overline{2}$ & $\overline{3}$ & Total \\
\hline $1^{\circ}$ exame & $108(99.09 \%)$ & $\mathbf{0}$ & $\mathbf{0}$ & $1(0.91 \%)$ & $109(100 \%)$ \\
\hline $\mathbf{2}^{\circ}$ exame & $103(100 \%)$ & $\mathbf{0}$ & $\mathbf{0}$ & $\mathbf{0}$ & $103(100 \%)$ \\
\hline $3^{\circ}$ exame & 99 (100\%) & $\mathbf{0}$ & $\mathbf{0}$ & $\mathbf{0}$ & 99 (100\%) \\
\hline $4^{\circ}$ exame & $88(98.88 \%)$ & $\mathbf{0}$ & $1(1.12 \%)$ & $\mathbf{0}$ & $89(100 \%)$ \\
\hline
\end{tabular}

O desgaste variou de 0 a 3, sendo 0 ausência e 3 o desgaste extremo. Observou-se associação entre fraturas na porcelana e presença de hábitos parafuncionais.

Tabela $\mathbf{n}^{\circ}$ 64:Presença de desgaste na porcelana da prótese da mandíbula

Número de pacientes

\begin{tabular}{l|c|c|c|c|c}
\hline & 0 & 1 & 2 & 3 & Total \\
\hline $1^{\circ}$ exame & $105(96.34 \%)$ & $3(2.75 \%)$ & $1(0.91 \%)$ & 0 & $109(100 \%)$ \\
\hline $2^{\circ}$ exame & $99(96.12 \%)$ & $3(2.91 \%)$ & $1(0.97 \%)$ & 0 & $103(100 \%)$ \\
\hline $3^{\circ}$ exame & $97(97.98 \%)$ & $2(2.02 \%)$ & 0 & 0 & $99(100 \%)$ \\
\hline $4^{\circ}$ exame & $88(98.88 \%)$ & $1(1.12 \%)$ & 0 & 0 & $89(100 \%)$ \\
\hline
\end{tabular}

O desgaste variou de 0 a 3, sendo 0 ausência e 3 o desgaste extremo. Observou-se associação entre fraturas na porcelana e presença de hábitos parafuncionais.

Tabela $\mathbf{n}^{\circ}$ 65: Necessidade de reembasamento do clipe da sobre-dentadura da maxila correspondendo

\begin{tabular}{l|c|c|c}
\hline \multicolumn{4}{c}{ Número de pacientes } \\
\hline & Índice 0 & Índice 1 & Total \\
\hline $1^{\circ}$ exame & $108(99.09 \%)$ & $1(0.91 \%)$ & $109(100 \%)$ \\
\hline $2^{\circ}$ exame & $103(100 \%)$ & 0 & $103(100 \%)$ \\
\hline $3^{\circ}$ exame & $99(100 \%)$ & 0 & $99(100 \%)$ \\
\hline $4^{\circ}$ exame & $89(100 \%)$ & 0 & $89(100 \%)$ \\
\hline
\end{tabular}

O índice 1 indica reembasamento do clipe e o zero para ausência. 
Tabela $\mathbf{n}^{\circ}$ 66: Necessidade de reembasamento do clipe da sobre-dentadura da mandíbula

\begin{tabular}{l|c|c|c}
\hline & \multicolumn{3}{|c}{ Número de pacientes } \\
\hline & Índice 0 & Índice 1 & Total \\
\hline $1^{\circ}$ exame & $107(98.17 \%)$ & $2(1.83 \%)$ & $109(100 \%)$ \\
\hline $2^{\circ}$ exame & $101(98.06 \%)$ & $2(1.94 \%)$ & $103(100 \%)$ \\
\hline $3^{\circ}$ exame & $96(96.97 \%)$ & $3(3.03 \%)$ & $99(100 \%)$ \\
\hline $4^{\circ}$ exame & $\mathbf{8 4}(94.39 \%)$ & $5(5.61 \%)$ & $89(100 \%)$ \\
\hline
\end{tabular}

O índice 1 indica reembasamento do clipe e o zero para au sência.

Tabela $\mathbf{n}^{\circ}$ 67: Realização de ajuste oclusal em próteses suportadas por implante na maxila

\begin{tabular}{l|c|c|c}
\hline \multicolumn{4}{c}{ Número de pacientes } \\
\hline & Indice 0 & Indice 1 & Total \\
\hline $1^{\circ}$ exame & $106(97.24 \%)$ & $3(2.75 \%)$ & $109(100 \%)$ \\
\hline $2^{\circ}$ exame & $102(99.03 \%)$ & $1(0.97 \%) 0$ & $103(100 \%)$ \\
\hline $3^{\circ}$ exame & $99(100 \%)$ & 0 & $99(100 \%)$ \\
\hline $4^{\circ}$ exame & $89(100 \%)$ & 0 & $89(100 \%)$ \\
\hline
\end{tabular}

O índice 1 equivaleu a presença e o 0 a ausência. Nos casos de reaperto ou fratura sucessiva do parafuso da prótese os contatos oclusais foram revisados e se necessário realizou-se ajuste oclusal. 
Tabela n68: Realização de ajuste oclusal em próteses suportadas por implante na mandíbula

\begin{tabular}{l|c|c|c}
\hline \multicolumn{4}{c}{ Número de pacientes } \\
\hline & Indice 0 & Indice 1 & Total \\
\hline $1^{\circ}$ exame & $103(94.50 \%)$ & $6(5.50 \% \%)$ & $109(100 \%)$ \\
\hline $2^{\circ}$ exame & $103(94.48 \%)$ & 0 & $103(94.48 \%)$ \\
\hline $3^{\circ}$ exame & $95(87.15 \%)$ & $4(3.66 \%)$ & $99(90.81 \%)$ \\
\hline $4^{\circ}$ exame & $89(81.65 \%)$ & 0 & $89(81.65 \%)$ \\
\hline
\end{tabular}

O índice 1 equivaleu a presença e 0 a ausência. Nos casos de reaperto ou fratura sucessiva do parafuso da prótese os contatos oclusais foram revisados e se necessário realizou-se ajuste oclusal.

Tabela $\mathbf{n}^{\circ}$ 69: Distribuição do número de casos avaliados nos quatro exames, quanto ao valor mínimo, máximo, média e desvio padrão da profundidade de sondagem na vestibular (V) e lingual (L) dos implantes.

\begin{tabular}{c|c|c|c|c|c|c|c|c|c|c}
\hline & \multicolumn{2}{|c|}{$\begin{array}{c}N^{\circ} \text { de } \\
\text { pacientes }\end{array}$} & \multicolumn{2}{|c|}{ Valor mínimo } & \multicolumn{2}{c|}{ Valor máximo } & \multicolumn{2}{c}{ Média } & \multicolumn{2}{l}{ Desvio Padrão } \\
\hline Exame & V & L & V & L & V & L & V & L & V & L \\
& & & & & & & & & & \\
\hline $1^{\circ}$ & 109 & 109 & 1.00 & 1.00 & 4.17 & 4.00 & 1.72 & 1.69 & 0.647 & 0.652 \\
\hline $2^{\circ}$ & 103 & 103 & 1.00 & 1.00 & 4.00 & 3.00 & 1.63 & 1.59 & 0.608 & 0.595 \\
\hline $3^{\circ}$ & 99 & 99 & 1.00 & 1.00 & 4.00 & 4.00 & 1.64 & 1.67 & 0.644 & 0.718 \\
\hline $4^{\circ}$ & 89 & 89 & 1.00 & 1.00 & 4.00 & 4.50 & 1.66 & 1.62 & 0.687 & 0.702 \\
\hline
\end{tabular}


Tabela n70: Distribuição do número de casos avaliados no primeiro exame, quanto ao valor mínimo, máximo, média e desvio padrão do nível de inserção sondagem na vestibular (V) e lingual (L) dos implantes.

\begin{tabular}{l|c|c|c|c|c|c|c|c|c|c}
\hline & \multicolumn{2}{|l|}{$N^{\circ}$ de pacientes } & \multicolumn{2}{l|}{ Valor mínimo } & \multicolumn{2}{l|}{ Valor máximo } & \multicolumn{2}{l}{ Média } & \multicolumn{2}{l}{ Desvio Padrão } \\
\hline same & V & L & V & L & V & L & V & L & V & L \\
& & & & & & & & & & \\
\hline $1^{\circ}$ & 109 & 109 & 1.11 & 0.50 & 7.33 & 7.50 & 4.32 & 4.34 & 1.361 & 1.442 \\
\hline $2^{\circ}$ & 103 & 103 & 0.78 & 0.50 & 7.33 & 7.83 & 4.30 & 4.20 & 1.320 & 1.386 \\
\hline $3^{\circ}$ & 99 & 99 & 1.11 & 0.50 & 7.33 & 7.83 & 3.93 & 3.98 & 1.426 & 1.469 \\
\hline $4^{\circ}$ & 89 & 89 & 1.00 & 0.50 & 7.17 & 7.50 & 3.46 & 3.41 & 1.561 & 1.609 \\
\hline
\end{tabular}

Tabela ${ }^{\circ}$ 71: Distribuição nos quatro exames do percentual de faces com presença e ausência de placa nas faces vestibulares (V) e linguais (L) dos implantes.

\begin{tabular}{c|c|c|c|c|c|c}
\hline & \multicolumn{2}{|c|}{ N $^{\circ}$ de pacientes } & \multicolumn{2}{c}{ Valor 0 } & \multicolumn{2}{c}{ Valor 1 } \\
\hline Exame & V & L & V & L & V & L \\
& & & & & & \\
\hline $1^{\circ}$ & 109 & 109 & $68.64 \%$ & $75.23 \%$ & $31.36 \%$ & $24.76 \%$ \\
\hline $2^{\circ}$ & 103 & 103 & $82.71 \%$ & $78.97 \%$ & $17.29 \%$ & $21.03 \%$ \\
\hline $3^{\circ}$ & 99 & 99 & $89.87 \%$ & $76.56 \%$ & $10.13 \%$ & $23.44 \%$ \\
\hline $4^{\circ}$ & 89 & 89 & $92.61 \%$ & $85.48 \%$ & $7.39 \%$ & $14.52 \%$ \\
\hline
\end{tabular}


Tabela $\mathbf{n}^{\circ}$ 72: Distribuição nos quatro exames do percentual de implantes com presença e ausência de sangramento a sondagem nas faces vestibulares e/ou linguais.

\begin{tabular}{c|c|c|c}
\hline & $\mathbf{N}^{\circ}$ de pacientes & Valor 0 & Valor 1 \\
\hline Exame & & V /L & V / L \\
\hline $1^{\circ}$ & 109 & $\mathbf{8 1 \%}$ & $\mathbf{1 9 \%}$ \\
\hline $2^{\circ}$ & 103 & $\mathbf{9 2 . 8 5 \%}$ & $\mathbf{7 . 1 5 \%}$ \\
\hline $3^{\circ}$ & 99 & $\mathbf{9 1 . 2 0 \%}$ & $\mathbf{5 . 8 \%}$ \\
\hline $4^{\circ}$ & $\mathbf{8 9}$ & $\mathbf{9 6 . 2 \%}$ & $\mathbf{3 . 8 \%}$ \\
\hline
\end{tabular}

Tabela n ${ }^{\circ}$ 73: Distribuição nos quatro exames do percentual de implantes com presença e ausência de edema nas faces vestibulares e/ou linguais.

\begin{tabular}{c|c|c|c}
\hline & $\mathbf{N}^{\circ}$ de pacientes & Valor 0 & Valor 1 \\
\hline Exame & & V /L & V /L \\
\hline $1^{\circ}$ & 109 & $95.6 \%$ & $4.3 \%$ \\
\hline $2^{\circ}$ & 103 & $97.90 \%$ & $\mathbf{2 . 1 0 \%}$ \\
\hline $3^{\circ}$ & 99 & $96.6 \%$ & $\mathbf{3 . 4 0} \%$ \\
\hline $4^{\circ}$ & 89 & $\mathbf{9 8 . 7 2 \%}$ & $\mathbf{1 . 2 8 \%}$ \\
\hline
\end{tabular}

Tabela $\mathbf{n}^{\circ}$ 74: Distribuição nos quatro exames do percentual de implantes com presença e ausência de alteração na coloração nas faces vestibulares e/ou linguais.

\begin{tabular}{c|c|c|c}
\hline & $\mathbf{N}^{\circ}$ de pacientes & Valor 0 & Valor 1 \\
\hline Exame & & V /L & V /L \\
\hline $1^{\circ}$ & 109 & $96.54 \%$ & $3.56 \%$ \\
\hline $2^{\circ}$ & 103 & $97.68 \%$ & $2.32 \%$ \\
\hline $3^{\circ}$ & 99 & $96.20 \%$ & $3.80 \%$ \\
\hline $4^{\circ}$ & 89 & $98.57 \%$ & $1.43 \%$ \\
\hline
\end{tabular}


Tabela n ${ }^{\circ}$ 75: Distribuição nos quatro exames do percentual de implantes com presença e ausência de mobilidade entre dois instrumentos.

\begin{tabular}{c|c|c|c}
\hline Exame & $\mathbf{N}^{\circ}$ de pacientes & Valor 0 & Valor 1 \\
\hline $1^{\circ}$ & 109 & $100 \%$ & $0 \%$ \\
\hline $2^{\circ}$ & 103 & $100 \%$ & $0 \%$ \\
\hline $3^{\circ}$ & 99 & $98.87 \%$ & $1.13 \%$ \\
\hline $4^{\circ}$ & 89 & $97.47 \%$ & $\mathbf{2 . 5 3 \%}$ \\
\hline
\end{tabular}

Tabela n 76: Distribuição nos quatro exames do percentual de implantes com presença e ausência de supuração nas faces vestibulares e/ou linguais.

\begin{tabular}{c|c|c|c}
\hline & $\mathbf{N}^{\circ}$ de pacientes & Valor 0 & Valor 1 \\
\hline Exame & & V /L & V /1 \\
\hline $1^{\circ}$ & 109 & $99.13 \%$ & $0.87 \%$ \\
\hline $2^{\circ}$ & 103 & $100 \%$ & $0 \%$ \\
\hline $3^{\circ}$ & 99 & $98.87 \%$ & $1.13 \%$ \\
\hline $4^{\circ}$ & 89 & $100 \%$ & $0 \%$ \\
\hline
\end{tabular}

Tabela $\mathbf{n}^{\circ}$ 77: Notas aferidas pelos pacientes ao tratamento com prótese sobre implante, em relação a função, estética e conforto na maxila e mandíbula.

\begin{tabular}{c|c|c|c|c|c|c}
\hline & \multicolumn{2}{|c|}{ Função } & \multicolumn{2}{c}{ Estética } & \multicolumn{2}{c}{ Conforto } \\
\hline & Maxila & Mandíbula & Maxila & Mandíbula & Maxila & Mandíbula \\
\hline N $^{\circ}$ de casos & 130 & 281 & 130 & 281 & 130 & 281 \\
\hline Mínimo & 5.00 & 4.00 & 5.00 & 4.00 & 5.00 & 4.00 \\
\hline Máximo & 10 & 10 & 10 & 10 & 10 & 10 \\
\hline Média & 9.49 & 9.59 & 9.40 & 9.47 & 9.66 & 9.65 \\
\hline Desvio padrão & 1.234 & 1.092 & 1.173 & 1.180 & 1.022 & 1.010 \\
\hline
\end{tabular}


Tabela $\mathbf{n}^{\circ}$ 78: Fator de correção e valores da perda óssea medida em milimetros radiograficamente no $1^{\circ}, 2^{\circ}, 3^{\circ}$ e $4^{\circ}$ exames nas faces mesiais e distais.

Os valores da perda óssea foram previamente corrigidos pelo número expresso na primeira coluna, obtido entre a partir da diferença entre o comprimento real do implante e o mensurado na radiografia em milimetros no programa Sigma Scan Pro, a fim de detectar possíveis distorções nas radiografias. As siglas dos pacientes encontram-se descritas no Apêndice 2 e o asterisco $\left({ }^{*}\right)$ indica ausência no exame.

\begin{tabular}{|c|c|c|c|c|c|c|c|c|c|}
\hline & & \multicolumn{2}{|c|}{$1^{\circ}$ Exame } & \multicolumn{2}{|c|}{$2^{\circ}$ Exame } & \multicolumn{2}{|c|}{$3^{\circ}$ Exame } & \multicolumn{2}{|c|}{$4^{\circ}$ Exame } \\
\hline PACIENTE & Correção & $\mathbf{M}$ & D & $\mathbf{M}$ & D & M & D & $\mathbf{M}$ & D \\
\hline $\mathbf{A 1}$ & 104.7 & 1.55 & 1.40 & 1.68 & 1.60 & 1.77 & 1.80 & 1.90 & 2.10 \\
\hline $\mathbf{A 2}$ & 104.7 & 1.41 & 1.56 & 1.90 & 1.63 & 1.89 & 1.63 & 2.25 & 1.90 \\
\hline $\mathbf{A 3}$ & 101.2 & 1.03 & 2.00 & 1.49 & 1.43 & 1.33 & 1.50 & 1.83 & 1.60 \\
\hline A4 & 102.9 & 1.82 & 1.53 & 1.92 & 1.73 & 2.03 & 1.83 & 2.10 & 2.05 \\
\hline A5 & 91.6 & 1.30 & 1.23 & 1.52 & 1.41 & 1.78 & 1.83 & 2.00 & 2.13 \\
\hline A6 & 85.5 & 1.21 & 1.23 & 1.51 & 1.52 & 1.67 & 1.56 & 1.89 & 2.10 \\
\hline A7 & 85 & 1.03 & 1.12 & 1.23 & 1.32 & 1.83 & 1.81 & 2.10 & 2.02 \\
\hline A8 & 89.7 & 1.10 & 1.02 & 1.34 & 1.36 & 1.67 & 1.54 & 2.21 & 2.01 \\
\hline B1 & 89.3 & 1.16 & 1.21 & 1.41 & 1.52 & 1.62 & 1.63 & 2.14 & 2.22 \\
\hline B2 & 94.6 & 1.55 & 1.34 & 1.59 & 1.54 & 1.87 & 1.98 & * & * \\
\hline B3 & 96 & 1.41 & 1.26 & 1.67 & 1.74 & 1.98 & 1.96 & * & * \\
\hline B4 & 92.9 & 1.03 & 1.33 & 1.72 & 1.10 & 1.87 & 1.99 & 1.78 & 1.76 \\
\hline B5 & 81.3 & 1.82 & 1.56 & 1.65 & 1.62 & 1.76 & 1.99 & 2.14 & 2.32 \\
\hline B6 & 103.7 & 1.30 & 1.24 & 1.59 & 1.67 & 1.87 & 1.89 & 2.23 & 2.65 \\
\hline B7 & 98.3 & 1.21 & 1.36 & 1.65 & 1.76 & 1.97 & 1.87 & 2.15 & 2.56 \\
\hline B8 & 96.4 & 1.03 & 1.23 & 1.61 & 1.63 & 1.71 & 1.88 & 1.86 & 2.23 \\
\hline C1 & 96.6 & 1.10 & 1.31 & 1.41 & 1.51 & 1.61 & 1.76 & 2.10 & 2.33 \\
\hline C2 & 107.6 & 1.16 & 1.23 & 1.45 & 1.56 & 1.87 & 1.89 & 2.11 & 2.33 \\
\hline C3 & 119.5 & 1.10 & 1.34 & * & * & * & * & * & * \\
\hline C4 & 97.6 & 1.20 & 1.78 & 1.45 & 1.32 & 1.67 & 1.56 & 1.87 & 1.76 \\
\hline C5 & 92.1 & 1.31 & 1.83 & 1.98 & 2.13 & 2.08 & 2.10 & 2.23 & 2.33 \\
\hline C6 & 123.4 & 1.41 & 1.34 & * & * & * & * & * & * \\
\hline C7 & 96.6 & 1.34 & 1.89 & 1.65 & 1.76 & 1.56 & 1.90 & 1.98 & 1.87 \\
\hline C8 & 101.8 & 1.24 & 1.67 & 1.65 & 1.45 & 1.78 & 1.55 & 2.13 & 2.56 \\
\hline D1 & 124.5 & 1.13 & 1.76 & * & * & * & * & * & * \\
\hline D2 & 92.6 & 1.23 & 1.09 & 1.22 & 1.33 & 1.34 & 1.88 & 1.99 & 1.88 \\
\hline D3 & 102.5 & 1.12 & 1.32 & 1.24 & 1.88 & 1.88 & 1.99 & 2.34 & 2.87 \\
\hline D4 & 120.4 & 1.32 & 1.45 & 1.51 & 1.78 & 1.34 & 1.88 & 1.98 & 1.66 \\
\hline D5 & 94.2 & 1.57 & 1.76 & 1.87 & 1.88 & 1.98 & 1.99 & 2.12 & 2.34 \\
\hline D6 & 87.3 & 1.87 & 1.14 & 1.55 & 1.43 & 1.23 & 1.54 & 1.88 & 1.76 \\
\hline D7 & 83 & 1.23 & 1.34 & 1.65 & 1.43 & 1.87 & 1.99 & 2.13 & 2.45 \\
\hline D8 & 94.8 & 1.69 & 1.45 & 1.55 & 1.67 & 1.99 & 1.98 & 2.14 & 2.45 \\
\hline E1 & 104.3 & 1.88 & 1.04 & 1.13 & 1.33 & 1.98 & 1.87 & 2.13 & 2.34 \\
\hline E2 & 97.1 & 1.78 & 1.04 & 1.23 & 1.34 & 1.86 & 1.91 & 2.10 & 2.14 \\
\hline E3 & 95 & 1.21 & 1.09 & 1.23 & 1.35 & 1.48 & 1.47 & 2.14 & 2.24 \\
\hline E4 & 97.4 & 1.87 & 1.07 & 1.13 & 1.24 & 1.56 & 1.67 & 2.34 & 2.14 \\
\hline E5 & 97.8 & 1.69 & 1.21 & 1.34 & 1.35 & 1.45 & 1.67 & 2.13 & 2.34 \\
\hline E6 & 97.5 & 1.56 & 1.09 & 1.45 & 1.41 & 1.56 & 1.65 & 2.13 & 2.34 \\
\hline & & \multicolumn{2}{|c|}{$1^{\circ}$ Exame } & \multicolumn{2}{|c|}{$2^{\circ}$ Exame } & \multicolumn{2}{|c|}{$3^{\circ}$ Exame } & \multicolumn{2}{|c|}{$4^{\circ}$ Exame } \\
\hline PACIENTE & Correção & $\mathbf{M}$ & D & $\mathbf{M}$ & D & $\mathbf{M}$ & D & M & D \\
\hline E7 & 96.6 & 1.23 & 1.13 & 1.34 & 1.35 & 1.43 & 1.56 & 2.14 & 2.65 \\
\hline
\end{tabular}




\begin{tabular}{|c|c|c|c|c|c|c|c|c|c|}
\hline E8 & 90.4 & 1.12 & 1.13 & 1.56 & 1.99 & 2.13 & 2.45 & 2.56 & 2.76 \\
\hline F1 & 97.3 & 1.35 & 1.34 & 1.86 & 1.97 & 2.13 & 2.14 & 2.13 & 2.65 \\
\hline F2 & 102.9 & 1.09 & 1.13 & 1.45 & 1.75 & 1.08 & 1.98 & 2.34 & 2.98 \\
\hline F3 & 98.5 & 1.12 & 1.13 & 1.23 & 1.43 & 1.13 & 1.89 & 1.99 & 2.13 \\
\hline F4 & 98.6 & 1.03 & 1.23 & * & * & * & * & * & * \\
\hline F5 & 98.7 & 1.06 & 1.13 & 1.34 & 1.45 & 1.55 & 1.97 & 2.13 & 2.14 \\
\hline F6 & 95.6 & 1.16 & 1.45 & 1.68 & 1.90 & 1.53 & 1.46 & 1.98 & 2.13 \\
\hline F7 & 88.8 & 1.76 & 1.87 & 1.56 & 1.98 & 1.64 & 1.56 & 2.14 & \\
\hline F8 & 95.4 & 1.08 & 1.13 & 1.56 & 1.93 & 1.87 & 1.76 & * & * \\
\hline G1 & 92.6 & 1.06 & 1.08 & 1.13 & 1.24 & 1.34 & 1.67 & * & * \\
\hline G2 & 100.9 & 1.05 & 1.98 & 1.23 & 1.34 & 1.57 & 1.89 & 2.35 & 2.55 \\
\hline G3 & 91.7 & 1.09 & 1.13 & 1.24 & 1.35 & 1.45 & 1.67 & 2.09 & 2.66 \\
\hline G4 & 98.6 & 1.32 & 1.32 & 1.45 & 1.43 & * & * & * & * \\
\hline G5 & 94.9 & 1.12 & 1.24 & 1.34 & 1.54 & 1.67 & 1.98 & * & * \\
\hline G6 & 96.8 & 1.09 & 1.13 & 1.24 & 1.35 & 1.47 & 1.95 & 2.16 & 2.54 \\
\hline G7 & 94.6 & 1.13 & 1.09 & 1.36 & 1.76 & 1.57 & 1.98 & 2.45 & 2.56 \\
\hline G8 & 98.3 & 1.34 & 1.5 & 1.48 & 1.67 & 1.98 & 1.94 & 2.34 & 2.45 \\
\hline H1 & 102.3 & 1.07 & 1.14 & 1.34 & 1.45 & 1.54 & 1.64 & 2.45 & 2.56 \\
\hline H2 & 106.7 & 1.17 & 1.16 & 1.54 & 1.56 & 1.87 & 1.85 & 2.14 & 2.25 \\
\hline H3 & 103.5 & 1.24 & 1.32 & 1.67 & 1.76 & 1.98 & 1.98 & 2.46 & 2.35 \\
\hline H4 & 102.3 & 1.06 & 1.02 & 1.76 & 1.87 & * & * & * & * \\
\hline H5 & 102 & 1.13 & 1.24 & 1.46 & 1.23 & 1.65 & 1.87 & 2.55 & 2.75 \\
\hline H6 & 113.6 & 1.09 & 1.13 & 1.24 & 1.54 & 1.78 & 1.98 & 2.15 & 2.34 \\
\hline H7 & 95.2 & 1.14 & 1.34 & 1.35 & 1.66 & 1.76 & 1.95 & 2.77 & 2.65 \\
\hline H8 & 104 & 1.06 & 1.05 & 1.13 & 1.45 & 1.98 & 1.77 & 2.98 & 2.77 \\
\hline I1 & 104.3 & 1.23 & 1.35 & 1.53 & 1.43 & 1.56 & 1.75 & 2.35 & 2.54 \\
\hline 12 & 94.8 & 1.09 & 1.46 & 1.35 & 1.54 & 1.35 & 1.98 & 2.13 & 2.34 \\
\hline I3 & 98.8 & 1.08 & 1.03 & 1.45 & 1.65 & 1.65 & 1.97 & * & * \\
\hline 14 & 96.7 & 1.06 & 1.14 & 1.35 & 1.77 & 1.45 & 1.98 & 2.13 & 2.34 \\
\hline I5 & 98.4 & 1.27 & 1.45 & 1.56 & 1.66 & 1.76 & 1.83 & 2.35 & 2.65 \\
\hline 16 & 98.8 & 1.09 & 1.06 & 1.45 & 1.56 & 1.75 & 1.76 & 2.45 & 2.56 \\
\hline I7 & 101.2 & 1.34 & 1.14 & 1.35 & 1.45 & 1.87 & 1.98 & 2.43 & 2.45 \\
\hline 18 & 98.4 & 1.09 & 1.16 & 1.45 & 1.43 & 1.87 & 1.94 & 2.15 & 2.15 \\
\hline J1 & 103.3 & 1.06 & 1.14 & 1.37 & 1.36 & 1.74 & 1.95 & * & * \\
\hline J2 & 84.9 & 1.14 & 1.24 & 1.34 & 1.41 & 1.66 & 1.98 & * & * \\
\hline J3 & 98.0 & 1.03 & 1.04 & 1.24 & 1.35 & 1.76 & 1.65 & 2.14 & 2.23 \\
\hline J4 & 99 & 1.43 & 1.56 & 1.47 & 1.87 & 1.65 & 1.98 & 2.34 & 2.45 \\
\hline J5 & 101 & 1.34 & 1.25 & 1.43 & 1.78 & 1.56 & 1.96 & 2.35 & 2.98 \\
\hline J6 & 98.0 & 1.08 & 1.15 & 1.34 & 1.65 & 1.87 & 2.14 & 2.54 & 2.87 \\
\hline J7 & 97.6 & 1.12 & 1.15 & 1.46 & 1.76 & 1.98 & 2.34 & 2.87 & 2.56 \\
\hline J8 & 101.2 & 1.06 & 1.24 & * & * & * & * & * & * \\
\hline K1 & 96.6 & 1.09 & 1.24 & 1.35 & 1.66 & * & * & * & * \\
\hline K2 & 101.2 & 1.13 & 1.14 & 1.56 & 1.77 & 1.97 & 1.96 & 2.14 & 2.34 \\
\hline K3 & 111.7 & 1.14 & 1.56 & * & * & * & * & * & * \\
\hline K4 & 111.3 & 1.34 & 1.24 & 1.54 & 1.75 & * & * & * & * \\
\hline K5 & 108.6 & 1.09 & 1.03 & 1.23 & 1.41 & 1.81 & 1.98 & 1.76 & 2.34 \\
\hline K6 & 110.2 & 1.34 & 1.35 & 1.31 & 1.57 & 1.35 & 1.34 & $*$ & * \\
\hline K7 & 91.2 & 1.14 & 1.46 & 1.53 & 1.73 & 1.80 & 2.35 & 2.16 & 2.56 \\
\hline K8 & 89.3 & 1.39 & 1.25 & 1.87 & 1.46 & 1.43 & 1.86 & 1.97 & 1.78 \\
\hline & & \multicolumn{2}{|c|}{$1^{\circ}$ Exame } & \multicolumn{2}{|c|}{$2^{\circ}$ Exame } & \multicolumn{2}{|c|}{$3^{\circ}$ Exame } & \multicolumn{2}{|c|}{$4^{\circ}$ Exame } \\
\hline PACIENTE & Correção & $\mathbf{M}$ & D & $\mathbf{M}$ & D & $\mathbf{M}$ & D & $\mathbf{M}$ & D \\
\hline L1 & $88.1^{3}$ & 1.08 & 1.87 & 1.77 & 1.34 & 1.34 & 1.98 & 2.45 & 2.56 \\
\hline L2 & 93.4 & 1.23 & 1.45 & 1.43 & 1.45 & 1.52 & 1.67 & 1.47 & 2.34 \\
\hline L3 & 98.8 & 1.08 & 1.13 & 1.44 & 1.34 & 1.56 & 1.61 & 1.75 & 2.44 \\
\hline L4 & 76.2 & 1.23 & 1.34 & 1.53 & 1.76 & 1.46 & 1.87 & * & * \\
\hline
\end{tabular}




\begin{tabular}{c|c|c|c|c|c|c|c|c|c}
\hline L5 & 93.6 & 1.13 & 1.23 & 1.35 & 1.45 & 1.56 & 2.15 & 2.80 & 2.34 \\
\hline L6 & 97.8 & 1.27 & 1.34 & 1.47 & 1.58 & 1.85 & 1.97 & $*$ & $*$ \\
\hline L7 & 89 & 1.34 & 1.45 & 1.52 & 1.64 & 1.97 & 2.13 & 2.34 & 2.46 \\
\hline L8 & 97.3 & 1.08 & 1.03 & 1.12 & 1.43 & 1.56 & 1.23 & 1.45 & 1.34 \\
\hline $\mathbf{M ~ 1 ~}$ & 93.1 & 1.03 & 1.13 & 1.13 & 1.36 & 1.53 & 2.13 & 2.24 & 2.45 \\
\hline M2 & 85.0 & 1.34 & 1.35 & 1.14 & 1.24 & 1.45 & 1.23 & 1.93 & 1.86 \\
\hline M3 & 97.8 & 1.17 & 1.23 & 1.45 & 1.43 & 1.86 & 1.78 & 1.97 & 1.94 \\
\hline $\mathbf{M 4}$ & 90.5 & 1.14 & 1.30 & 1.48 & 1.51 & 1.67 & 1.84 & 2.16 & 2.14 \\
\hline $\mathbf{M 5}$ & 93.4 & 1.13 & 1.46 & 1.35 & 1.46 & 1.89 & 1.93 & 2.14 & 2.57 \\
\hline $\mathbf{M 6}$ & 92.6 & 1.13 & 1.57 & 1.23 & 1.34 & 1.44 & 1.57 & 2.14 & 2.34 \\
\hline $\mathbf{M 7}$ & 101.9 & 1.08 & 1.15 & 1.35 & 1.36 & 1.45 & 1.51 & 1.98 & 1.86 \\
\hline $\mathbf{M 8}$ & 108.4 & 1.25 & 1.51 & 1.72 & 1.73 & 1.82 & 1.92 & 2.15 & 2.52 \\
\hline $\mathbf{N 1}$ & 96.7 & 1.04 & 1.14 & 1.13 & 1.26 & 1.47 & 1.43 & 2.24 & 2.46 \\
\hline $\mathbf{N 2}$ & 102.3 & 1.13 & 1.34 & 1.24 & 1.62 & 1.61 & 1.97 & 2.13 & 2.47 \\
\hline $\mathbf{N 3}$ & 97.6 & 1.35 & 1.27 & 1.35 & 1.46 & 1.52 & 1.85 & 2.34 & 2.41 \\
\hline $\mathbf{N 4}$ & 101.3 & 1.23 & 1.34 & 1.42 & 1.52 & 1.64 & 1.90 & 2.13 & 2.432 \\
\hline $\mathbf{N 5}$ & 98.9 & 1.09 & 1.23 & 1.31 & 1.45 & 1.72 & 2.10 & 2.12 & 2.52 \\
\hline $\mathbf{N 6}$ & 101.2 & 1.30 & 1.34 & 1.46 & 1.53 & 1.88 & 2.06 & 2.34 & 2.45 \\
\hline
\end{tabular}

Tabela $\mathbf{n}^{\circ}$ 79: Valor da perda óssea média em milimetros entre o $1^{\circ}$ e $2^{\circ}, 2^{\circ}$ e $3^{\circ}, 3^{\circ}$ e $4^{\circ}$, e o $1^{\circ}$ e $4^{\circ}$ exames nas faces mesiais e distais, e o valor médio global.

\begin{tabular}{|l|c|c|c|c|}
\hline & \multicolumn{4}{|c|}{ Exames } \\
\hline & $\mathbf{1}^{\circ}-\mathbf{2}^{\circ}$ & $\mathbf{2}^{\circ}-\mathbf{3}$ & $\mathbf{3}^{\circ}-\mathbf{4}^{\circ}$ & $\mathbf{1}^{\circ}-\mathbf{4}^{\circ}$ \\
\hline Mesial & 0.23 & 0.24 & 0.48 & 0.95 \\
\hline Distal & 0.25 & 0.30 & 0.48 & 1.03 \\
\hline Média & 0.24 & 0.27 & 0.48 & 0.99 \\
\hline
\end{tabular}




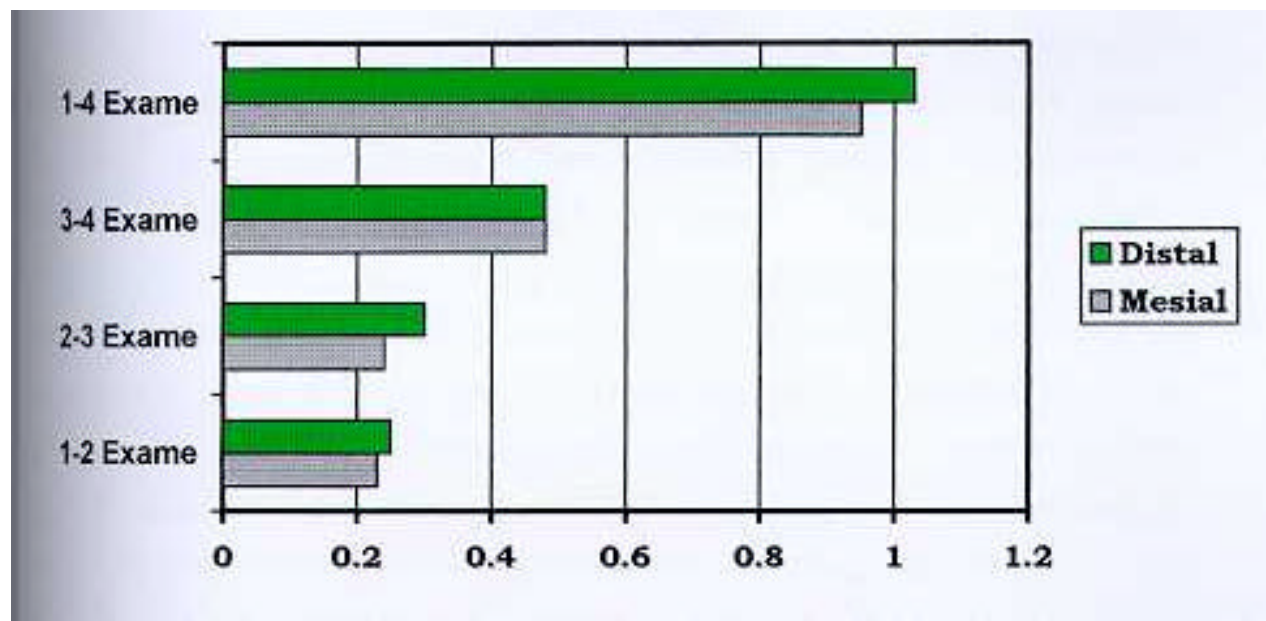

Figura $\mathbf{n}^{\circ}$ 10: Gráfico com os valores da perda óssea média em milímetros entre o $1^{\circ}$ e $2^{\circ}$, $2^{\circ}$ e $3^{\circ}, 3^{\circ}$ e $4^{\circ}$, e o $1^{\circ}$ e $4^{\circ}$ exames nas faces mesiais e distais, e o valor médio global.

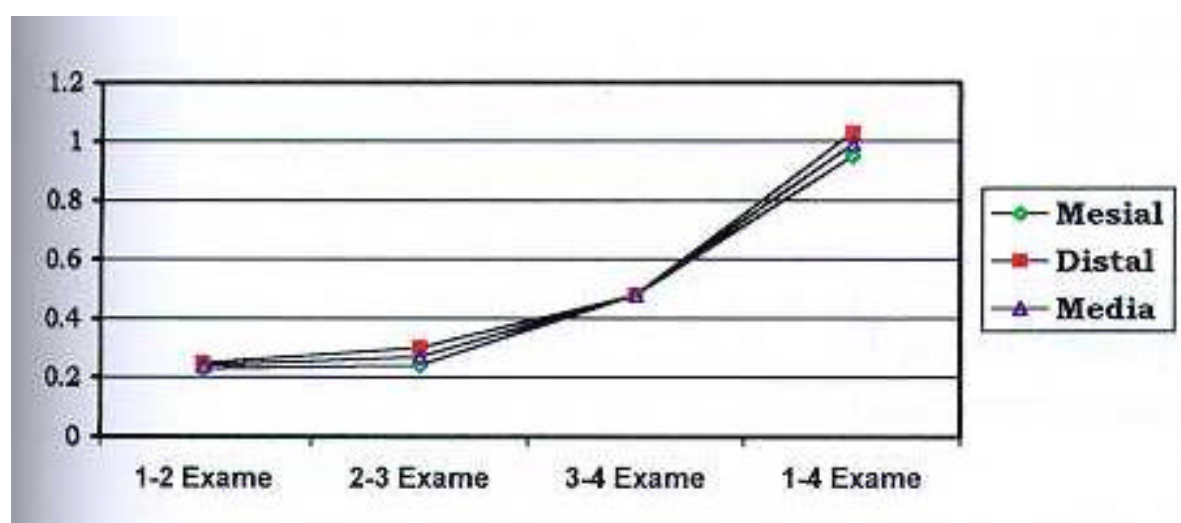

Figura $\mathbf{n}^{\circ}$ 11: Gráfico com os valores da perda óssea média em milímetros entre o $1^{\circ}$ e $2^{\circ}$, $2^{\circ}$ e $3^{\circ}, 3^{\circ}$ e $4^{\circ}$, e o $1^{\circ}$ e $4^{\circ}$ exames nas faces mesiais e distais, e o valor médio global. 

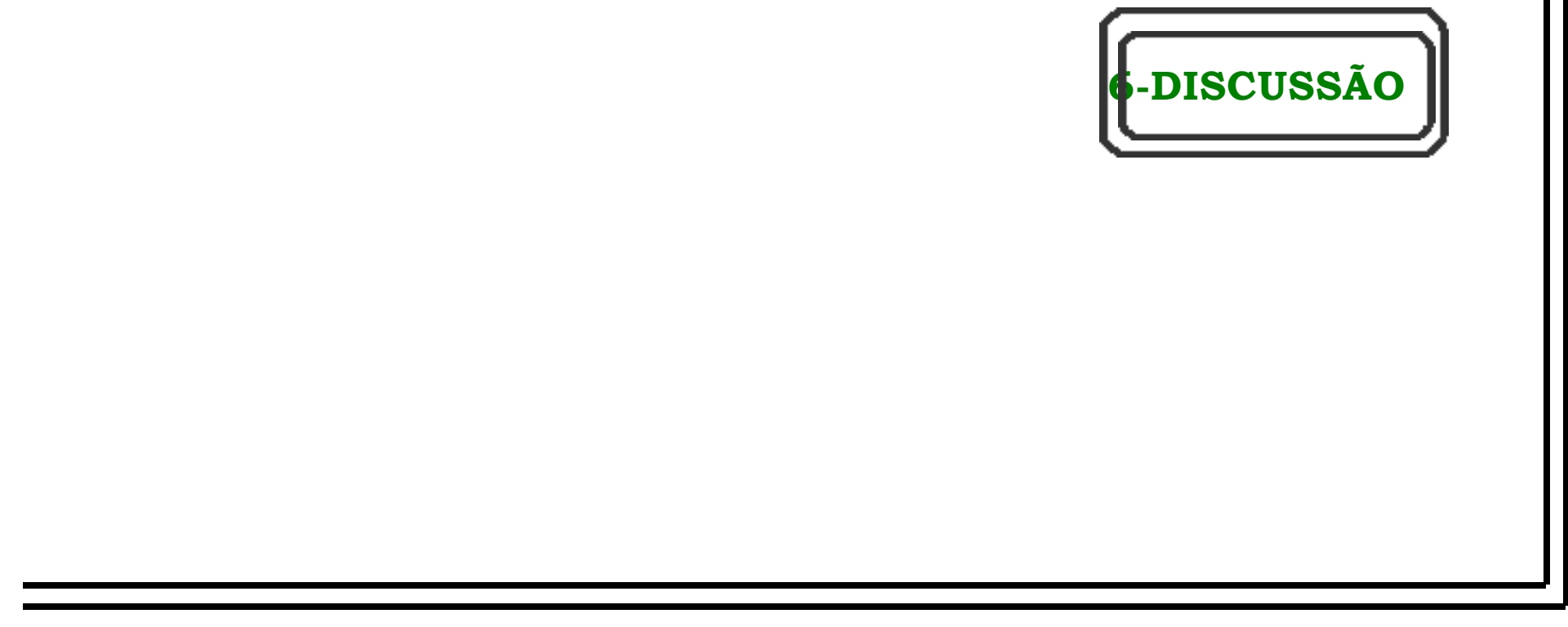


\section{6-DISCUSSÃO}

As próteses fixas, removiveis ou totais convencionais, ancoradas nos dentes remanescentes ou na mucosa, consistiam na única terapia disponivel para a reabilitação dos pacientes parcial ou totalmente desdentados. Entretanto, nos últimos anos, tornou-se realidade a reconstrução protética suportada por implantes firmemente ancorados no tecido ósseo. A substituição com sucesso dos dentes naturais ausentes por implantes de titânio devidamente integrados aos tecidos representou avanço de suma importância na Odontologia. Estes consistem alternativa com melhoria significativa funcional e estética com grande previsibilidade, revolucionando as perspectivas de tratamento dos casos avançados.

A previsibilidade apresentada pelos sistemas de implantes osseointegrados atualmente disponiveis se relaciona diretamente com as características especiais da interface existente entre osso e superficie do implante, e meios empregados para a sua obtenção. A "interface" significa região de interação entre implante e tecido circunjacente. A interface tem sido designada com termos como osseointegração09,10,11,13,16,39,34,123,128, adesão óssea195 e anquilose funcional 29,180. Osseointegração é a denominação mais utilizada, com ampla aceitação no meio científico. Com esta nomenclatura objetiva-se explicar a natureza da interação entre implante-tecido ósseo, como também dos fatores que influenciam a resposta tecidual apropriada do paciente e funcionalidade efetiva do implante a longo prazo.

Diversos fatores contribuem para a obtenção da interface apropriada, que está diretamente relacionada com o sucesso clínico do implante. A fim de avaliar corretamente as razões do sucesso dos implantes, o aspecto biológico atua como have na elucidação das razões que envolvem a sua alta previsibilidade. Através da conjunção de diversos fatores interligados, pode ser esperado contato próximo entre o titânio e o osso com reduzida margem de erro, obtendo-se 
osseointegração. Os fatores descritos a seguir 10,13,14,42,48, foram devidamente respeitados desde a fase de manufatura do implante, tratamento da superficie deste, seleção criteriosa das áreas de colocação das fixações com técnica cirúrgica em duas fases padronizadas e criteriosas, até a realização da prótese.

A escolha do material para utilização na confecção de implantes odontológicos baseia-se em propriedades físicas e químicas. Inicialmente, deve-se ressaltar a propriedade de biocompatibilidade, ou seja, capacidade de determinado material desenvolver resposta biológica no hospedeiro, e ao mesmo tempo, qualificar a resposta desse material frente ao ambiente biológico. A partir deste pressuposto, enfatiza-se que a superficie do material consiste na chave da biocompatibilidade de um sistema de implantes. A intolerância a determinado material estranho inserido no corpo humano provoca formação de leito fibroso, usualmente pouco vascularizado. Idealmente, o biomaterial deveria se integrar ao corpo com a inexistência de reações teciduais.

Em relação ao titânio grau I, utilizado na fabricação dos implantes analisados nesta pesquisa, deve-se salientar algumas características importantes, que justificam sua ampla utilização na Odontologia: baixo índice de dissolução no organismo, com ausência de efeitos cumulativos; biocompatibilidade com alta tolerância pelo corpo humano; e ausência quase absoluta de corrosão, proporcionada pela estabilidade estrutural acentuada. Esta última característica, se relaciona intimamente ao recobrimento da superficie mais externa do titânio por camada de óxidos superficiais estável.

Os fenômenos bioadesivos ocorrem entre a camada mais superficial do metal, e as biomoléculas que se aderem à esta. Esta interação bioquímica direta e estreita é fundamental para proporcionar resposta adequada do sistema biológico ao implante. Os óxidos superficiais são provenientes da alta reatividade do titânio, que ao menor contato com ar atmosférico, água ou eletrólitos forma esta camada mais externa. A composição destes difere do corpo do implante 
propriamente dito, e apresenta carga elétrica compativel com as células sanguíneas. Além disto, a presença da rugosidade superficial favorece a migração celular em direção às microranhuras.

Diversos estudos foram conduzidos com finalidade de caracterização da superficie do implante NAPIO (Núcleo de Apoio à Pesquisa em Implantes Odontológicos) 21,136,142,149,173. O implante segue diversas etapas de tratamento sendo realizada, inicialmente, a eliminação dos possiveis contaminantes da superficie provenientes da usinagem. Em seguida, estes foram tratados por ataque ácido através do protocolo NAPIO (Núcleo de Apoio à Pesquisa em Implantes Odontológicos), proporcionando recobrimento por camada de óxidos superficiais. Após a finalização desta etapa, cada implante foi colocado em ampola de vidro com álcool etílico a 10\%, fechados com uma seladora de ampola de vidro (Farmáquinas, modelo DM) e devidamente esterilizados em autoclave a $121^{\circ} \mathrm{C}$ por 20 minutos.

A função inicial da interface consiste na transferência precisa da carga do implante ao osso. A estabilidade primária da fixação se relaciona com três fatores: máxima proximidade fisica entre tecido ósseo e metal facilitando a remodelação circunjacente; inserção do implante idealmente travado em duas corticais proporcionando estabilidade inicial; e ausência de forças prematuras passiveis de promover micromovimentos entre o primeiro e segundo ato cirúrgico. Ao nível biológico, a ocorrência excessiva destes logo após a inserção do implante atuaria mecanicamente na região da interface. A interrupção repetida na seqüência de eventos usuais da cicatrização óssea, ocasionaria distúrbios nos eventos fisiológicos. Estes distúrbios promoveriam suplantação da cicatrização por tecido fibroso gerando reparo, em detrimento da regeneração óssea desejada. Idealmente, ausência de micromovimentos proporcionaria cicatrização óssea por padrão fisiológico adequado, obtendo-se integração entre osso e implante. Por estes motivos, obrigatoriamente, entre a primeira fase cirúrgica para inserção nos 109 pacientes das 371 fixações e a segunda para conexão dos intermediários não 
incidiram forças oclusais, respeitando o período de no mínimo 90 dias na mandíbula e 180 na maxila.

A formação de tecido mole na interface também pode se relacionar com trauma cirúrgico excessivo. Este advêm da ausência do controle da temperatura durante o procedimento, gerando danos cicatriciais irreversiveis e implicando em provável insucesso. Deve-se realizar a inserção do implante com alguns cuidados evitando o aquecimento excessivo: utilização de brocas novas e aumento gradual do diâmetro, irrigação contínua e abundante com soro fisiológico e baixa rotação. O controle criterioso da temperatura, proporciona dano mínimo associado a resposta tecidual máxima. A cirurgia de colocação dos implantes respeitou rigorosamente os padrões citados acima para controle apropriado da temperatura, reduzindo ao máximo o aquecimento do tecido ósseo.

Em relação à característica macroestrutural, o implante confeccionado no NAPIO (Núcleo de Apoio a Pesquisa de Implantes Odontológicos) possui forma similar a parafuso. Esta proporciona superficie de contato inicial superior à cônica sem tratamento especial da superficie, aumentando a intensidade dos fenômenos de osseointegração. Além disso, ancoragem mais firme favorece a estabilidade inicial, facilitando cicatrização tecidual e após a conexão da prótese distribuição mais uniforme das forças.

A amostra de 109 pacientes foi avaliada clínica e radiograficamente estabelecendo previamente o planejamento cirúrgico e protético. A inter-relação das duas especialidades nesta fase objetivou definir precisamente o número, comprimento e disposição dos implantes na fase cirúrgica em posição proteticamente favorável, de acordo com a análise radiográfica da disponibilidade óssea em qualidade e quantidade adequadas. A localização apropriada foi estabelecida através da confecção de um guia cirúrgico utilizado durante o exame radiográfico. O planejamento criterioso permite posterior confecção da reconstrução protética, respeitando a distribuição das forças mastigatórias com 
estética satisfatória e número reduzido de implantes adormecidos. Foram inseridas 371 fixações em ambiente cirúrgico totalmente aparelhado, seguindo normas rígidas de esterilização, e respeitando protocolo cirúrgico em dois estágios com padronização da técnica.

A conjunção dos fatores explanados acima proporciona a obtenção da osseointegração. Inicialmente o tecido ósseo cortado, com controle criterioso da temperatura, é preenchido por sangue e este se organiza em coágulo. Em um implante inicialmente estável, devido a forma macroscópica similar a parafuso com maior superficie de contato, sangue e coágulo se distribuem na superficie influenciados inicialmente pela energia superficial. Seqüencialmente, os óxidos superficiais intensificam a aderência entre superfície do óxido e biomoléculas. A microrugosidade atuaria na condutibilidade da migração celular na superficie do material biologicamente compativel ${ }^{48}$.

Para executar a análise dos resultados obtidos pelos implantes, como também de qualquer procedimento clínico, determinados princípios devem ser rigorosamente empregados. Os implantes até pouco tempo atrás, haviam sido apresentados sem respeitar princípios básicos usuais da pesquisa científica. Estes estudos limitavam-se a acompanhamentos de casos clínicos e relatos de opiniões pessoais repletos de empirismo, resultando em dados divergentes e de difícil interpretação. A maior parte dos trabalhos utilizava como principal critério de sucesso a permanência dos implantes na boca, sem considerar as características dos tecidos moles e duros adjacentes. Os critérios de sucesso são mais amplos e diferem do conceito de sobrevivência, porque o primeiro considera a qualidade da função do implante e tecido ósseo aplicáveis a todo implante inserido. Os critérios para avaliação do sucesso dos implantes se desenvolveram como tentativa de aquilatar o desempenho clínico dos diversos sistemas disponíveis, e como também no estabelecimento de parâmetros fidedignos de comparação entre estes. 
O valor da utilização de critérios de sucesso mais rígidos e restritos se baseia diretamente com obtenção de segurança e previsibilidade dos resultados do tratamento realizado. As ciências médicas devem primar por assegurar oferta de tratamento que perdure idealmente a vida toda. Os implantes osseointegrados se desenvolveram, e no decorrer dos anos os critérios de avaliação do sucesso deste se tornaram mais rígidos e restritivos. SCHNITMAN; SHULMAN ${ }^{181}$, no ano de 1979, admitiam como sucesso perda óssea igual a 1/3 do comprimento do implante. Em 1986, ALBREKTSSON et al. ${ }^{15}$ propuseram estandartização mais rigorosa com a média da perda inferior a $0.2 \mathrm{~mm}$ ao ano, e $85 \%$ dos implantes deveriam obter este valor em 5 anos. As exigências dos critérios de sucesso se tornaram mais restritivas, com a finalidade de assegurar qualidade no tratamento dos pacientes, através do controle de sistemas de implantes que não obtivessem os índices ideais. Esta rigidez proporciona resultados mais confiáveis e previsíveis, no tratamento com implantes osseointegrados. Apesar do caráter rigoroso dos critérios de sucesso propostos para os implantes osseointegrados, em nenhum destes se incluiu mensuração da saúde da mucosa peri-implantar. O desenvolvimento destes critérios se relaciona diretamente com progresso técnico e deve se envolver com a prática clínica. A partir desta idéia, os critérios de sucesso não deveriam se aplicar única e exclusivamente em pesquisa, mas também nas consultas de manutenção do clínico, pois o implante não deve apresentar-se com dor, mobilidade, infecção, ou seja, ausência de sinais e sintomas sugestivos de falha. O julgamento crítico e detecção precoce das falhas dos implantes osseointegrados pelo clínico, pode se enriquecer com a descoberta e aplicação de possíveis novos critérios utilizados em pesquisa, cada vez mais aperfeiçoados.

Dentre os critérios mais utilizados, nos acompanhamentos longitudinais para a determinação do sucesso da reabilitação por próteses suportadas por implantes osseointegrados, estão os de SCHNITMANN; SHULMAN ${ }^{181}$, do ano de 1979; ALBREKTSSON e colaboradores'15; em 1986; SMITH; ZARB ${ }^{186}$, em 1989. Sendo este último o mais abrangente com a adição aos critérios de ALBREKTSSON et al. ${ }^{15}$ da necessidade de conexão do implante à 
prótese de forma satisfatória para paciente e dentista, considerando as fixações adormecidas como falha. Os critérios de SMITH; ZARB ${ }^{186}$, do ano de 1989, apresentam-se listados abaixo:

1-Imobilidade do implante individualmente, não-conectado à prótese, quando examinado clinicamente;

2-A radiografia não deveria demonstrar evidência de radiolucidez periimplantar;

3-Presença de perda óssea vertical inferior a $0.2 \mathrm{~mm}$ anualmente, após o primeiro ano de utilização funcional dos implantes;

4-Ausência de sinais e sintomas irreversiveis e/ou persistentes, tais como: dor, infecção, neuropatias, parestesia ou violação do canal mandibular.

5-Considera-se implantes adormecidos não conectados a prótese como falha.

Utilizou-se os critérios de SMITH; ZARB186, do ano de 1989, para avaliar os dados coletados com 109 pacientes, durante 2 anos após a instalação da prótese. Os implantes foram classificados de acordo com a tabela de quatro campos de ALBREKTSSON, ZARB ${ }^{13}$, do ano de 1993, sendo utilizados os seguintes conceitos:

-Sucesso (Ss), aplicado aos casos devidamente testados em relação à imobilidade clínica entre dois instrumentos, ausência de radioluscidez peri-implantar e aos critérios de sucesso adotados;

-Sobrevivência (S1), para os implantes que permanecessem em função, contudo sem mencionar avaliação clínica, ou radiográfica ou critérios de sucesso definidos; -Não computado (U), para aqueles que não comparecessem aos retornos por qualquer motivo;

-Falha $(F)$, aplicados aos que fossem removidos independentemente do motivo da falha ou remoção. 
A partir da veiculação de sistemas de implantes com rigores da metodologia científica, eliminando-se o empirismo pré-existente, foram apresentados estudos da efetividade a longo prazo. Além da utilização de critérios de sucesso bem definidos, para que se possa aquilatar a efetividade dos diversos tipos de implantes, torna-se necessário o estabelecimento de metodologia básica de pesquisa comum a todos os trabalhos. Qualquer avaliação clínica deve respeitar parâmetros quantificáveis precisos, com ausência de variações individuais, permitindo a reprodução por diversos grupos de pesquisa com resultados similares.

A partir da divulgação dos estudos longitudinais sobre os implantes, o conceito de osseointegração iniciou nova era no tratamento clínico. Nestes trabalhos foram realizadas avaliações confiáveis respeitando critérios préestabelecidos, abrangendo número significativo de pacientes, durante períodos longos. Como resultado obteve-se alto percentual de previsibilidade clínica, possibilitando posteriormente a ampla utilização nos diversos tipos de edentulismo.

Os trabalhos longitudinais de acompanhamento clínico dos implantes osseointegrados se iniciaram com a publicação de ADELL et al.02, em 1981. Este trabalho representou um marco na Implantodontia, com a introdução de nova metodologia de avaliação do sucesso dos implantes. A partir deste estudo inicial foram apresentadas diversas avaliações $01,02,04,05,16,23,24,56,63,64,65,67,71,81,85,90,101,105,108,109,127,137,144,192,202,207$ a longo prazo em pacientes totalmente desdentados reabilitados por próteses suportadas por implantes osseointegrados em centros de diferentes países. Os pacientes foram avaliados trimestral ou semestralmente no primeiro ano, e anualmente nos períodos subseqüentes, de acordo com os critérios adotados. A taxa de sucesso dos implantes na maxila variou de $81 \%$ a $92 \%$ e de $91 \%$ a $100 \%$ na mandíbula. Em relação à estabilidade das prótese obteve-se valores variando entre $79 \% \mathrm{e}$ $96 \%$. 
Inicialmente, os implantes foram utilizados exclusivamente na reabilitação de pacientes totalmente edêntulos. Gradualmente extrapolou-se a utilização dos implantes osseointegrados para indivíduos parcialmente desdentados. No ano de 1986, ERICSSON e colaboradores ${ }^{72}$ foram os pioneiros no relato da avaliação, em relação a função e reação tecidual, do tratamento de pacientes parcialmente edêntulos por implantes osseointegrados conjugados aos dentes remanescentes através de encaixes de precisão. Subseqüentemente a este, foram apresentados diversos trabalhos $25,30,44,45,47,78,84,86,91,95,102,103,105,116,129,152,154,166,192,193,196,209$ de acompanhamento de pacientes parcialmente edêntulos tratados por implantes osseointegrados. Nestes estudos foram obtidos índices de sucesso similares aos dos pacientes totalmente edêntulos, variando de $92.8 \%$ a 99\% na mandíbula, $82 \%$ a 94\% para maxila e estabilidade das próteses oscilando entre 94.6 e 100\% dos casos.

A fase protética dos pacientes totalmente edêntulos reabilitados por implantes osseointegrados apresentava-se bem estabelecida. Isto se alterou com a introdução dos implantes osseointegrados nos pacientes parcialmente edêntulos. Considerou-se nestes as diferenças na resiliência existente entre os micromovimentos inerentes à presença do ligamento periodontal e à imobilidade do implante rigidamente unido ao osso. Esta situação criou o dilema da união ou não dos dentes e fixações na reconstrução protética pela possibilidade de gerar intrusão das unidades dentárias. Diversos trabalhos longitudinais recomendam manter-se os dentes e implantes isolados durante a reabilitação protética 52,103,193,164,195, em outros não se contra-indica25,40,72. Entretanto a situação se torna mais complexa se o número de implantes é insuficiente para suprir o segmento desdentado e os dentes adjacentes apresentam-se com perda óssea. Em nenhum dos pacientes examinados nesta tese a prótese parcial suportada por implante foi conectada aos dentes adjacentes, por este motivo não foi possível estabelecer observação conclusiva acerca da possibilidade de intrusão dos dentes. 
Nos últimos anos, foram apresentados diversos acompanhamentos longitudinais de reconstruções unitárias ancoradas em implantes $17,37,54,85,92,93,104,106,125,145,161,180,182$. A comparação dos resultados da estabilidade dos implantes suportando elementos unitários, se apresentou semelhante aos obtidos nos casos de edentulismo total ou parcial. O percentual de sucesso dos implantes variou de 91 a 100\% e a estabilidade das próteses foi superior a $90 \%$.

$\mathrm{Na}$ amostra da tese foram englobados 109 pacientes, sendo 66 mulheres e 43 homens, correspondendo a respectivamente $60.66 \%$ e $39.44 \%$ (Tabela $\mathrm{n}^{\circ}$.6). Nos trabalhos de acompanhamento longitudinal geralmente verificase concentração acentuada de mulheres, em relação a homens $\mathrm{s}^{01,02,04,37,44,56,71,85,91,109,120,132,167}$. A idade dos pacientes variou de 17 a 82 anos (Tabela $n^{\circ} .7$ ), com maior número englobado na faixa etária de 41 a 70 anos (Tabela $n^{\circ} .8$ ), e esta observação correspondeu a faixa etária usualmente acompanhada nos estudos $01,02,04,56,71,72,75,85,89,91,102,106,109,129,132,194$. No acompanhamento clínico conduzido durante dois anos com 109 pacientes monitorou-se os implantes incluídos de forma criteriosa, clínica e radiograficamente com padronização, acompanhando as complicações e registrando as falhas, mediante a adoção dos critérios de sucesso de SMITH; ZARB ${ }^{186}$ e classificação dos implantes pela tabela de quatro campos de ALBREKTSSON; ZARB ${ }^{13}$. O trabalho de coleta dos dados foi conduzido imediatamente após a instalação da prótese, seis meses depois, um ano e dois anos após o primeiro exame. No primeiro exame compareceram 109 pacientes com 371 implantes avaliados, no segundo 103 indivíduos com 352 implantes, no terceiro 99 com 326 e no quarto e último 89 pacientes com 311 implantes. Esta distribuição está representada na tabela de $n^{\circ} .9$.

O percentual de sucesso dos implantes classificados de acordo com a tabela de quatro campos, de ALBREKTSSON; ZARB, em 199313, no primeiro 
exame foi de $93.40 \%$ e $98.12 \%$, no segundo exame apresentou-se com $86.80 \%$ e $93.58 \%$, no terceiro exame com $79.24 \%$ e $86.41 \%$, e no quarto com $78.30 \%$ e $79.24 \%$, respectivamente para a maxila e mandíbula (Tabela $n^{\circ} 16$ ). Os valores apresentaram-se sensivelmente decrescentes pela influência dos não computados, ou seja pelos pacientes que não compareceram as consultas de manutenção, e não pelo incremento das falhas em si. A apresentação dos dados somente do sucesso na maxila e mandíbula foi de, respectivamente, $93.39 \%$ e $98.12 \%$ no primeiro exame, $96.93 \%$ e $98.03 \%$ no segundo, $94.37 \%$ e $97.87 \%$ no terceiro, e $90.21 \%$ e $95.90 \%$ no quarto exame. Estes resultados encontram-se compativeis com os relatados na literatura descritos acima pertinentes ao acompanhamento de implantes osseointegrados, com o índice de sucesso variando de $92 \%$ a $100 \%$ na mandíbula, e de 81 a 92\% na maxila. Foram adormecidos 3 implantes, sendo 2 na maxila e 1 na mandibula, por se apresentarem em local proteticamente desfavorável, correspondendo a $0.8 \%$ dos implantes e $16.66 \%$ das falhas. Os valores na literatura de implantes adormecidos variam de $0.3 \%$ a $4.34 \%$ dos implantes $16,20,56,89$, e os achados da tese se compatibilizaram com estes. Os implantes inseridos em 7 pacientes com enxerto ósseo autógeno obtiveram 100\% de sucesso, entretanto a amostra foi muito reduzida para este representar dado conclusivo. Nos estudos de avaliação do percentual de sucesso dos implantes inseridos em locais submetidos a radiação obteve-se variação de $57.9 \%$ a $62.6 \% 07,80,157,162$, contudo nenhum dos pacientes foi submetido a tal tratamento e não existem dados comparativos disponíveis. Os 109 pacientes possuíam 135 próteses suportadas por implantes dos seguintes tipos: 25 próteses unitárias, 20 sobre-dentaduras, 27 tipo protocolo, 37 parciais com 2 elementos, 24 parciais com 3 elementos e 2 parciais com 4 elementos. Estes dados de distribuição das próteses estão apresentados na tabela $\mathrm{n}^{\circ} .28$. Durante os dois anos de acompanhamento das próteses somente uma foi substituída por fratura da infraestrutura (Tabela $n^{\circ}$. 31) obtendo-se percentual de estabilidade da prótese de $99.25 \%$ na maxila e $100 \%$ na mandíbula (Tabela $n^{\circ}$. 18). Na literatura descrita anteriormente a estabilidade da prótese variou de $79 \%$ a $100 \%$ e os dados divulgados no presente trabalho concordam com estes valores. 
Os indices de sucesso dos implantes osseointegrados se apresentaram bastante elevados nos relatos da literatura. Em estudos longitudinais 02,57,71,75,81,101,166,167,193,195,207,211 detectou-se concentração das falhas dos implantes preponderantemente até a segunda fase cirúrgica, em seguida o percentual de falhas se reduz durante o primeiro ano após instalação da prótese, e nos anos subsequentes a este período ocorre estabilização das perdas. Os resultados com até 30 anos de avaliação não demonstraram alterações discrepantes em relação aos obtidos com os dois anos iniciais $07,54,81,95,103,113,124,167,193,207$. Registrou-se uma curva de estabilização de perda dos implantes, após os dois primeiros anos para quase todos os sistemas de implantes, exceto o IMZ. Estes implantes demonstraram perda progressiva durante a avaliação de 60 meses sendo perdidos 30 implantes, dos quais 9 não se integraram no segundo ato cirúrgico e 21 após a instalação da prótese ${ }^{28}$. Obteve-se resultado similar na avaliação de implantes IMZ em osso tipo IV, com 22 falhas durante 36 meses, sendo que 8 ocorreram na segunda fase cirúrgica, 3 durante o primeiro ano de acompanhamento, e 11 após 24 a 36 meses em função ${ }^{77}$. ALBREKTSSON; ZARB ${ }^{12}$, em 1993 correlacionaram o desempenho deficiente a longo prazo do sistema IMZ provavelmente com a forma cilíndrica, porção coronal polida demais e procedimento cirúrgico traumático em demasia. A partir destes pressupostos, deve-se ressaltar como extremamente importantes os resultados obtidos pelos sistemas de implantes osseointegrados nos periodos iniciais, especialmente até a segunda cirurgia e nos primeiros dois anos após a conexão da prótese com incidência de cargas oclusais. $\mathrm{Na}$ amostra de 109 pacientes avaliada nesta tese, as falhas se concentraram na segunda fase cirúrgica, em comparação com as perdas de implantes detectadas nos 2 anos de acompanhamento da prótese. Foi registrada concentração até a segunda cirurgia de mais de $75 \%$ das falhas da maxila com 7 das 9 falhas e superior a 55\% na mandíbula com 5 das 9 falhas. Estes dados encontram-se apresentados na tabela $\mathrm{n}^{\circ}$.19. Este resultado demonstrou a tendência de concentração das falhas até a segunda fase cirúrgica e reduzindo estas nos dois primeiros anos de acompanhamento da prótese. Conclui-se que a interface entre titânio e tecido 
ósseo apresenta tolerância e adaptação fisiológica crescentes com o declínio acentuado das falhas. Registrou-se na literatura tendência de concentração das falhas em poucos indivíduos ${ }^{63,65}$, sendo que nos pacientes da tese 3 pacientes responderam por 8 das 18 falhas, ou seja, concentração de $44 \%$ das perdas. Esta concentração se apresenta na tabela $n^{\circ}$. 19. O trabalho de acompanhamento longitudinal das próteses suportadas por implantes do sistema NAPIO necessita continuar para permitir a manutenção das próteses sobre implante e verificação das taxas de sucesso atestando ou não a estabilização do percentual de falhas.

Diversos trabalhos 30,55,77,91,100,195 demonstraram a predileção na ocorrência das falhas em áreas de qualidade e quantidade óssea reduzidas, estabelecidas através da classificação proposta por LEKHOLM; ZARB ${ }^{128}$, no ano de 1985. Observou-se concentração das falhas em determinadas áreas com osso tipo IV, como por exemplo na região posterior da maxila, sendo confirmada a influência marcante da qualidade óssea no prognóstico de sucesso dos implantes. A falha de implantes foi superior na maxila confirmando a predileção desta em detrimento da mandíbula, pois apesar do mesmo número de falhas de 9 implantes em cada arcada, a amostra da mandíbula foi significativamente maior. Além deste aspecto, em alguns estudos 30,75,95,109,192,195 apresentou-se a conjunção de tecido ósseo menos denso com a inserção de implantes mais curtos, especialmente o de $7 \mathrm{~mm}$, como responsáveis pela obtenção dos piores resultados clínicos. Na tabela de $\mathrm{n}^{\circ} .19$ foi apresentada a correlação entre as falhas e o comprimento dos implantes. Nos pacientes acompanhados durante 2 anos todos os implantes que não se osseointegraram na segunda fase cirúrgica ou perderam esta após instalação da prótese possuíam comprimento igual ou inferior a $10 \mathrm{~mm}$. Esta observação se apresentou compativel com os relatos da literatura, confirmando a tendência de concentração das perdas em implantes curtos.

O tabagismo tem sido correlacionado como fator atuante na acentuação das falhas de implantes osseointegrados $31,32,59,63,79,87,111,133$. O fumo possui mais de 4000 substâncias tóxicas e dentre estas destacam-se a nicotina, 
cianido de hidrogênio e monóxido de carbono. Estas atuariam como vasoconstrictores reduzindo acentuadamente a microvascularização, diminuindo o aporte sanguíneo e dos nutrientes na área, e comprometendo significativamente a cicatrização dos pacientes fumantes ${ }^{184}$. Nesta tese não se observou diferenças significativas na concentração das falhas nos pacientes fumantes, em relação aos não fumantes. Nos fumantes registrou-se $27.77 \%$ das falhas e nos não fumantes $73.33 \%$ destas. A relação dos pacientes com falha de implantes, em relação ao hábito de fumar se apresenta na tabela $\mathrm{n}^{\circ} .19$.

Nos estudos de acompanhamento longitudinal, usualmente, alguns pacientes não comparecem nas consultas de manutenção. Na literatura relata-se evasão de $4.3 \%^{106}$ e $18 \%^{93}$ em um ano, $8.5 \%^{115}$ e $11 \%^{124}$ em dois, $11 \%$ com três ${ }^{19,124}$ e aos 5 anos $14 \%{ }^{18}$. Nesta tese, no primeiro ano de acompanhamento $13.20 \%$ dos pacientes reabilitados na maxila e $11.69 \%$ na mandíbula não se apresentaram para a manutenção. No segundo ano, na maxila o percentual se manteve igual ao primeiro ano e na mandíbula aumentou para $17.35 \%$. Os dados obtidos com a ausência de pacientes se apresentam similares aos relatados na literatura, sendo esta a maior dificuldade na condução desta pesquisa. $\mathrm{Na}$ primeira consulta procurava-se enfatizar a necessidade deste exame na preservação da prótese sobre implante. Como em todo tratamento médico ou odontológico procurou-se ao máximo estabelecer vínculos com simpatia e presteza entre o profissional e o paciente. Objetivou-se estabelecer relacionamento agradável, sólido, repleto de confiança no profissional e enchendo o paciente de satisfação e vontade de retornar para o próximo exame. Com esta conduta a pesquisa foi enriquecida não somente pela coleta de dados, como também pelo relacionamento humano harmonioso. Em muitos casos participei de problemas, doenças, notícias boas e ruins, enfim interagi com os pacientes tornando este contato de quatro exames extremamente enriquecedor não somente no aspecto científico, mas especialmente no humano. Os pacientes foram questionados para designar nota de 0 a 10, em relação a função, estética e conforto da prótese, e média das notas encontram-se dispostas na tabela $n^{\circ}$. 77 , sendo que a média 
sempre foi superior a 9. No trabalho de SMEDBERG ${ }^{185}$, do ano de 1991, a média das notas aferidas pelos pacientes para função, estética e conforto foi de, respectivamente, 7.6, 9.0 e 8.1. Relata-se que os pacientes apresentam segurança social mais acentuada após o tratamento com implantes osseointegrados incrementando as relações pessoais e sociais ${ }^{25,90,109,118,200}$. Na tese através das notas objetivou-se medir subjetivamente a satisfação do paciente com o tratamento. A média das notas para a maxila e mandíbula demonstrou que o tratamento supriu a expectativa dos pacientes e apresentou compatibilidade com a literatura. Enfim, nesta tese comprovou-se que os implantes representaram impacto psicológico positivo nos pacientes satisfazendo os anseios destes quanto a função, estética e fonética.

A osseointegração consiste em definição histológica com repercussões clínicas e radiográficas ${ }^{13}$. Em relação aos aspectos clínicos, as alterações teciduais que acarretam perda do implante podem ocorrer de forma lenta, dificultando detecção precisa do momento em que aconteceu a falha. A partir da aparente similaridade morfológica clínica do tecido peri-implantar e gengival utilizou-se parâmetros clínicos usuais em Periodontia no intuito de monitorar a longo prazo a saúde dos implantes. Fundamentando-se nestes conceitos, alguns autores $02,03,20,54,56,72,92,104,124,167,169,196$ ressaltaram a necessidade de incluir parâmetros clínicos utilizados usualmente no diagnóstico da doença periodontal na avaliação dos implantes osseointegrados. Os seguintes parâmetros foram propostos $02,03,20,54,56,72,92,104,124,167,169,196$ : profundidade de sondagem, nível de inserção, comprimento da gengiva ceratinizada, supuração, sangramento à sondagem, índices de placa e gengival. Incorporou-se na tese para avaliação clínica dos implantes os seguintes parâmetros: profundidade de sondagem, distância do topo do intermediário a margem gengival, nível de inserção como a soma destes dois primeiros valores, presença de placa, sangramento a sondagem, edema, alteração na coloração, mobilidade entre dois instrumentos e supuração. Existem controvérsias na literatura, quanto a interdependência estreita entre valores de profundidade de sondagem e nível de inserção, em relação a altura 
óssea mensurada radiograficamente; como também quanto a utilização dos indices periodontais na avaliação longitudinal dos implantes, em relação ao propósito e interpretação. Na literatura tanto existe concordância168,201, quanto discordância em relação a confiabilidade dos parâmetros comparados com o nível ósseo radiográfico $20,131,161$, e na possibilidade de detecção precoce das falhas pela monitoração destes ${ }^{20}$.

A profundidade de sondagem peri-implantar deve-se realizar utilizando sonda plástica, a fim de não se danificar a superfície do intermediário. Nas figuras $\mathrm{n}^{\circ} .1$ e 2 encontra-se demonstrada a sonda plástica utilizada para medir profundidade de sondagem durante os quatro exames. LANG et al. ${ }^{124}$, avaliou histologicamente a penetração da sonda periodontal em implantes inseridos em cães com graus diversos de inflamação do tecido peri-implantar. Obteve-se penetração mais acentuada em presença de inflamação dos tecidos moles peri-implantares. Concluiu-se que a sondagem poderia ser utilizada como meio acessivel, fácil e rápido para monitorar o estado de saúde dos tecidos moles peri-implantares e detectar alterações potencialmente deletérias na região periimplantar. NEWMAN; FLEMING ${ }^{155}$, em 1988, consideraram satisfatório se a sondagem conseguisse alcançar sempre o limite apical do sulco ou bolsa, entretanto a conformação do implante pode, em alguns casos, impedir a penetração da sonda gerando valor falso negativo. Sugeriu-se também a adoção de ponto fixo para monitorar a longo prazo qualquer alteração na profundidade de sondagem. Com este intuito, BECKER e colaboradores ${ }^{38}$, mediram a profundidade de sondagem e somaram a distância do topo do intermediário a margem gengival obtendo o nivel de inserção em volta dos implantes. Nos dentes utiliza-se a junção cemento-esmalte como ponto de referência e nos implantes o topo do intermediário. Nos pacientes da tese examinados, durante 2 anos, depois da remoção da prótese procedeu-se a medida da profundidade de sondagem, da distância do topo do intermediário a margem gengival e estes valores foram somados obtendo-se o nível de inserção. A média de profundidade de sondagem na literatura variou de $2.6 \mathrm{~mm}$ a $3.1 \mathrm{~mm}^{02,03,72,131,63}$ e neste trabalho foi na face 
vestibular de $1.72 \mathrm{~mm}, 1.69,1.64$ e $1.65 \mathrm{~mm}$ e na lingual de $1.69 \mathrm{~mm}, 1.59 \mathrm{~mm}$, $1.67 \mathrm{~mm}$ e $1.62 \mathrm{~mm}$, respectivamente, no primeiro, segundo, terceiro e quarto exame (tabela $n^{\circ}$. 69). O nível de inserção foi obtido através da soma entre profundidade de sondagem e distância do topo do intermediário a margem gengival. O valor de nível de inserção variou de $4.32 \mathrm{~mm}, 4.30 \mathrm{~mm}, 3.93 \mathrm{~mm}$ e $3.46 \mathrm{~mm}$ na face vestibular, e na lingual de $4.34 \mathrm{~mm}, 4.20 \mathrm{~mm}, 3.98 \mathrm{~mm}$ e 3.41 $\mathrm{mm}$, respectivamente do primeiro ao quarto exame (tabela $\mathrm{n}^{\circ} .70$ ). A profundidade de sondagem e o nível de inserção apresentaram redução nos quatro exames, contudo a do nivel de inserção foi um pouco mais acentuada.

A presença de placa apresentou-se como reflexo direto da cooperação do paciente com a higienização da área e na literatura variou de $13.6 \%$ a $50 \%$ das faces com placa $02,03,23,45,54,104,131,167$, sendo que neste estudo reduziu do primeiro ao quarto exame de $31.36 \%$ na vestibular para $7.39 \%$, e na face lingual de $24.76 \%$ para $14.52 \%$ (Tabela $n^{\circ} 71$ ). O acúmulo de placa nos implantes apresentase usualmente mais reduzido que nas unidades dentárias. Cogita-se três possibilidades para esta observação: 1.motivação mais acentuada do paciente; 2.placa não se acumula no mesmo padrão que no dente, devido à aderência reduzida ao titânio; 3.possivel potencial antimicrobiano do titânio; 4. diferenças na microbiota dos pacientes reabilitados por implantes osseointegrados em comparação com os dentados 20 . Durante o atendimento dos pacientes observouse aderência reduzida da placa sobre os intermediários com remoção pela utilização de curetas plásticas (Figura ${ }^{\circ} 7$ ) e muitas vezes somente pelo spray de água e ar.

O índice de sangramento a sondagem na literatura variou de $7.6 \%$ a $43.7 \%$ das faces $02,03,45,54,56,131,167,169$ e neste trabalho se enquadrou em $19 \%$ no primeiro exame diminuindo acentuadamente para 3.8\% das faces (Tabela $n^{\circ} 72$ ). A presença de placa e sangramento a sondagem apresentaram-se com redução acentuada atestando a cooperação dos pacientes com a higienização. Quanto a presença de edema observou-se variação de $4.3 \%$ no primeiro para $1.28 \%$ dos 
implantes no quarto exame (Tabela ${ }^{\circ} 73$ ), como também reduziu-se a alteração na coloração de $3.56 \%$ dos implantes para $1.43 \%$ (Tabela $n^{\circ} 74$ ) e supuração só foi detectada no primeiro e terceiro exame em, respectivamente, $0.87 \%$ e $1.13 \%$ dos implantes(Tabela $\left.\mathrm{n}^{\circ} 75\right)$. A mobilidade clínica se relaciona diretamente a presença de cápsula de tecido conjuntivo envolvendo a fixação, sendo que todo implante móvel deve ser removido, já que não se recupera a osseointegração155,186. A mobilidade e a radioluscidez peri-implantar detectada radiograficamente mensuram aspectos similares da resposta peri-implantar. Foi registrada mobilidade entre dois instrumentos no terceiro exame em $1.13 \%$ dos implantes e no quarto exame de $2.53 \%$ (Tabela $n^{\circ} 75$ ). Os parâmetros clínicos foram incluídos neste estudo com a possibilidade de atuarem no diagnóstico precoce de qualquer alteração, podendo favorecer intervenção antes do incremento da gravidade e da irreversibilidade do quadro. Contudo, as falhas não foram identificadas precocemente com a utilização dos parâmetros clínicos periodontais, e os radiográficos na maior parte dos casos foram mais decisivos na detecção destas.

O exame radiográfico apresenta-se como ferramenta de diagnóstico necessária ao monitoramento dos pacientes a longo prazo como meio nãoinvasivo, sem necessidade de remoção da prótese e capaz de acessar alterações em diversos sítios simultaneamente. GRÖNDAHL;LEKHOLM ${ }^{82}$, em 1997, avaliaram o valor prognóstico positivo das radiografias na identificação da estabilidade de 2000 implantes, sem remover a prótese, durante 3 anos Obteve-se valor prognóstico positivo de $83 \%$ das falhas somente pela imagem radiográfica, sendo que somente em $11 \%$ dos casos removeu-se a prótese desnecessariamente, pois os implantes permaneciam estáveis. Para a realização da comparação longitudinal precisa deve-se utilizar técnica padronizada de posição, exposição e processamento dos filmes. Nesta tese utilizou-se posicionadores individualizados pela mordida em resina tipo Duralay (Figuras $\mathrm{n}^{\circ} 3,4,5$ e 6) permitindo a padronização da posição do filme, além do tempo de exposição estipulado em 0.6 na maxila e 0.8 na mandíbula, em aparelho de raio-x com potência de $70 \mathrm{KVp}$, como também revelação dos filmes em máquina de processamento automático. 
Como principais desvantagens das radiografias ressalta-se a dificuldade de detecção de alterações ósseas iniciais, e deficiência na visualização das estruturas por consistir em imagem bidimensional de estrutura tridimensional. Em alguns casos, quando se detecta área de radiolucidez peri-implantar já existe ausência real de osseointegração. Nas radiografias de implantes suportando próteses podese avaliar a condição do tecido ósseo peri-implantar, grau de perda óssea marginal longitudinal e em alguns casos visualizar o estado e adaptação dos componentes mecânicos. O acompanhamento radiográfico a longo prazo da perda óssea peri-implantar foi realizado por diversos autores $^{02,18,19,26,63,65,72,74,89,90,91,95,104,105,109,115,116,124,134,137,145,152,154,158,169,182,196 . ~ N o ~}$ primeiro ano detectou-se perda óssea radiograficamente mensurada variando em média de 0.5 a $1.5 \mathrm{~mm}$. Em seguida, com a prótese em função, registrou-se perda óssea anual variando de 0.03 a $0.1 \mathrm{~mm}$. Justifica-se esta estabilização na perda óssea devido ao equilíbrio entre as forças atuantes e a capacidade de remodelação do osso de suporte. Nesta tese as radiografias foram digitalizadas em scanner de slides para posterior avaliação em programa específico (Sigma Scan Pro), visando aumentar a sensibilidade do método. Neste programa foi registrado o valor real do implante, sendo este comparado com a medida radiográfica do comprimento do implante em milimetros. Esta conduta permitiu incorporar no valor da perda óssea radiográfica dos quatro exames as possíveis distorções com encurtamento ou alongamento da imagem. O fator correção e os valores medidos corrigidos por este estão apresentados na tabela de $\mathrm{n}^{\circ} 78$. Nas faces mesiais e distais, obteve-se perda óssea entre o primeiro e segundo exames, respectivamente, de $0.23 \mathrm{~mm}$ e $0.25 \mathrm{~mm}$, do segundo ao terceiro foi de $0.24 \mathrm{~mm}$ e $0.30 \mathrm{~mm}$, e entre o terceiro e o quarto em ambas as faces obteve-se $0.48 \mathrm{~mm}$. Durante dois anos de avaliação a perda óssea na face mesial foi de $0.95 \mathrm{~mm}$ e na distal com 1.03, sendo o valor médio de $0.97 \mathrm{~mm}$. Estes valores encontram-se compativeis com os apresentados na literatura. 
A perda óssea no primeiro ano pode ser explicada pela incidência de cargas oclusais depois da instalação da prótese ou contaminação por microorganismos do espaço entre a fixação e o intermediário. HOWSHAM; BRUNSKI; COCHRAN ${ }^{97}$, em 1994, avaliaram a incidência de cargas mecânicas oclusais nos implantes suportando próteses em cães. Detectou-se mediante a incidência de forças perda óssea e redução do conteúdo mineral próximo à porção coronal do implante. Concluiu-se que o modelamento e remodelamento secundário aos microdanos ósseos se relacionam diretamente ao protocolo de forças empregado. Seguindo esta mesma linha de raciocínio, PILLIAR e colaboradores ${ }^{165}$, avaliaram a influência da conformação do implante no remodelamento ósseo em cães e conclui que existe inter-relação direta entre estes. Sugeriu-se que o estresse reduzido resulta na perda óssea devido a atrofia por desuso e o estresse acentuado provocaria microfraturas indutoras de reabsorção subsequente do osso em contato com a fixação. Nos anos subsequentes ao primeiro de instalação da prótese ocorreria equilíbrio biomecânico entre forma do implante e as forças estabilizando a perda óssea. Em oposição a esta linha de pensamento, ERICSSON e colaboradores ${ }^{73}$, detectaram, em cortes histológicos de cães expostos ao acúmulo de placa, presença de infiltrado celular inflamatório adjacente à junção entre a fixação e o intermediário. Hipotetizou-se que este infiltrado expressaria tentativa pelo hospedeiro de vedamento do espaço "infectado" e a presença deste explicaria a perda óssea durante o primeiro ano subsequente à instalação da prótese.

$\mathrm{Na}$ fase de manutenção das próteses sobre implantes podem ocorrer diversas complicações. Nas próteses retidas a parafuso ocorre com mais frequência a fratura, reaperto ou troca dos parafusos da prótese ou do intermediário, sendo os problemas com o parafuso da prótese mais freqüentes, que os do intermediário $36,85,88,90,93,102,119,129,137,151,182,187,197,208$. A fratura do parafuso do intermediário também se apresentou neste trabalho com percentual mais reduzido do que o parafuso da prótese (Tabela $n^{\circ} 33$ e $34 \times$ Tabela $n^{\circ} .35$ e 36). Durante os quatro exames foram registradas diversas complicações, sendo a 
mais comum o reaperto dos parafusos da prótese (Tabela $\mathrm{n}^{\circ}: 51$ e 52) e a fratura destes (Tabela $n^{\circ} 35$ e 36). O reaperto do parafuso da prótese, necessidade de torque no intermediário, troca do parafuso da prótese por desgaste no encaixe ou espanado, fratura do parafuso da prótese e do intermediário foram mais freqüentes na mandíbula, do que na maxila. Em oposição a esta observação CARLSSON; CARLSSON ${ }^{49}$, no ano de 1994, relataram incidência mais acentuada de complicações na maxila do que na mandíbula.

O reaperto se concentrou nos dois primeiros exames alcançando equilíbrio e permanecendo firme nos exames seguintes (Tabela $\mathrm{n}^{\circ} .51$ e 52). JEMT et al. ${ }^{106}$, em 1992, e LANEY et al. ${ }^{124}$, em 1994, também detectaram redução da necessidade de reaperto dos parafusos com a progressão do acompanhamento. Usualmente, quando os parafusos se encontraram frouxos se associou a presença de mobilidade na prótese sobre implante e a frequência desta complicação também foi reduzindo com o decorrer dos exames (Tabela $n^{\circ} 43$ e 44). Em alguns casos associou-se parafusos da prótese e do intermediário soltos, sendo realizado o torque no intermediário com motor (Tabela $n^{\circ} .53$ e 54). Durante a remoção e colocação da prótese observou-se em algumas houve necessidade da troca dos parafusos espanados ou com problema no encaixe, e este foi computado nas tabelas de $\mathrm{n}^{\circ} .61$ e 62. Mediante a ocorrência de fraturas do parafuso ou afrouxamento da prótese ou do intermediário realizou-se a checagem dos contatos oclusais e se necessário a eliminação de contatos inadequados. Na tabela $n^{\circ} 67$ e 68 encontram-se dispostos os dados relativos ao ajuste oclusal.

$\mathrm{Na}$ tabela 63 e 64 encontram-se demonstrados os dados relativos ao desgaste da porcelana com os índices variando de 0 a 3 , correspondendo o 0 a ausência e desgaste da morfologia variando do grau 1 ao 3 . Nesta apresenta-se desgaste mais acentuado na maxila, em relação a mandíbula e concentração do maior número de ocorrências no índice 1. HENRY; TOLMAN; BOLENDER, relataram como complicação mais freqüente a fratura da superfície oclusal das 
próteses. No presente trabalho ocorreram algumas fraturas, mas esta complicação não excedeu os problema advindos do reaperto e fraturas de parafusos.

MORGAN; JAMES; PILLIAR ${ }^{150}$, avaliaram por microscopia eletrônica de varredura parafusos fraturados clinicamente e compararam com a imagem de exemplares submetidos a forças cíclicas ou excessivas. Concluiu-se que os parafusos pela presença de estrias fraturaram por fadiga induzida pela incidências contínua de forças fisiológicas. Ressaltou-se a importância do monitoramento clínico criterioso detectando precocemente alterações ósseas e na harmonia oclusal com distribuição equilibrada das forças. Neste trabalho de tese a fratura do parafuso da prótese (figura $n^{\circ} 8$ ) se concentrou em poucos indivíduos e em alguns com mais de um evento. Nestes investigou-se a possivel causa como por exemplo: desadaptação da infra-estrutura, ausência de harmonia oclusal e hábitos parafuncionais 36,119,187,191. Após a identificação da causa foi solucionado o problema, a fim de controlar as fraturas, pois negligência destas poderia facilitar a recorrência e provocar complicações mais graves. A remoção dos parafusos da prótese e do intermediário fraturados foi realizada com a utilização de duas sondas exploradoras que se encaixam nas ranhuras da fratura e rotacionavam lentamente o parafuso até remove-lo.

Não se registrou durante os dois anos nenhuma fratura do implante, sendo esta relatada na literatura ${ }^{33}$. Em relação fratura da infra-estrutura da prótese, citam-se como possiveis causas: presença de defeito ou ausência de resistência do material empregado, espessura inadequada do metal empregado na infra-estrutura, áreas de solda sem resistência, distribuição inadequada do estresse e conformação inapropriada, hábito parafuncional 119,191. De acordo com PEREL, no ano de 1994, o hábito parafuncional possui poder destrutivo sobre os componentes mecânicos por ocasionar fadiga do metal e fratura, entretanto estes são passíveis de substituição. Contudo, a ocorrência sucessiva pode provocar perda óssea peri-implantar por micromovimentação ou sobrecarga. A regularidade e frequência de forças destrutivas se conjugam podendo ocasionar efeitos 
adversos, cumulativos e irreversiveis na prótese suportada por implantes. No quarto exame ocorreu a fratura de uma infra-estrutura, sendo removida e confeccionada nova prótese (Tabela 31 e 32). Esta paciente foi acompanhada nos quatro exames suspeitou-se da influência de hábitos parafuncionais por relato de período de estresse acentuado nos últimos meses. Recomendou-se à paciente, após a instalação da nova prótese utilização de placa miorrelaxante, para pelo menos se dissipar as forças incidentes na prótese suportada por implantes, já que não se poderia evitar a ocorrência do hábito parafuncional.

Identificou-se a ocorrência de fratura da prótese total na maxila quando na mandíbula se instalava prótese tipo protocolo (Tabela $n^{\circ} .41$ e 42) ou sobre-dentadura (Tabela $\mathrm{n}^{\circ} .39$ e 40). LINDQUIST; CARLSSON; GLANTZ ${ }^{132}$, no ano de 1987, registraram em acompanhamento durante 6 anos a fratura na linha média de 14 próteses totais, depois da instalação da prótese sobre implante no arco antagonista. Foi correlacionado este fato com o aumento da carga mastigatória, após a instalação da prótese suportada por implante fraturando a prótese total.

Relata-se a ocorrência nas sobre-dentaduras durante a fase de manutenção de fratura do clipe, em seguida o reembasamento da prótese por TOLMAN; LANEY191, em 1992. Entretanto, LINDQUIST; CARLSSON; GLANTZ132, registraram no primeiro ano principalmente a reativação do clipe, seguido da fratura deste e por fim do reembasamento da prótese. No trabalho desenvolvido as sobre-dentaduras, durante os dois anos de acompanhamento, apresentaram como principal complicação o reembasamento do clipe (Tabela $\mathrm{n}^{\circ} .65$ e 66), seguido da fratura deste (Tabela $n^{\circ} .37$ e 38) e por fim do reembasamento da prótese (Tabela $n^{\circ} .59$ e 60). As complicações relativas ao clipe apresentaram-se com maior frequência na mandíbula, do que na maxila.

As alterações na fonação (Tabela $n^{\circ} .45$ e 46), desconforto muscular (Tabela $\mathrm{n}^{\circ} .55$ e 56 ) e sintomatologia dolorosa na articulação 
temporo-mandibular (Tabela $\mathrm{n}^{\circ} .57$ e 58 ) foram registradas somente no primeiro exame e depois houve equilíbrio com ausência destes nos outros três exames. ZARB; SCHMITT208, em 1990 relataram a ocorrência transitória, similar a encontrada neste estudo, de desconforto muscular, desordens na articulação temporo-mandibular e dificuldade de fonação.

Os tecidos moles peri-implantares podem apresentar-se com proliferação de tecido hiperplásico, advinda da irritação tecidual crônica ou higiene bucal deficiente ${ }^{191}$. ARTZI et al. ${ }^{22}$, em 1993, enfatizaram que presença de gengiva ceratinizada peri-implantar facilitaria a manutenção reduzindo a vulnerabilidade à inflamação pelo aumento da resistência e estabilidade tecidual. Apesar de alguns autores defenderem que não existe necessidade da gengiva ceratinizada devido a similaridade dos resultados longitudinais de sucesso dos implantes com ou sem gengiva ceratinizada ${ }^{189}$, outros sugerem que o selamento peri-implantar atuaria protegendo o tecido conjuntivo e ósseo das agressões do meio externo, além do conforto e componente estético mais agradável para o paciente ${ }^{110,141}$. Segundo alguns estudos a ausência de gengiva ceratinizada favorece a hiperplasia tecidual $71,88,90,107,191$. Sugere-se como tratamento o incentivo à higiene bucal 11,88,90,107,191 e em alguns casos a excisão cirúrgica191. No presente estudo a detecção da inflamação dos tecidos moles peri-implantares encontra-se apresentada na tabela $n^{\circ} .29$ e 30, sendo a frequência similar na maxila e mandíbula, com redução na incidência de inflamação entre o primeiro e o último exame. Nestes pacientes foi somente reforçada a instrução de higiene bucal e monitorada cuidadosamente a reação do tecido mole peri-implantar.

Eventualmente ocorrem distúrbios sensoriais depois da cirurgia para inserção do implante e observa-se redução acentuada do grau do distúrbio e da extensão com o tempo. O período de resolução pode variar de 1 a 3 anos e o percentual de acometidos apresenta-se de $19 \%$ a 37\% 25,70, 91,109,191. Neste estudo em 4 pacientes detectou-se parestesia, contudo no segundo exame esta se resolveu em metade dos pacientes e no terceiro e quarto exame reduziu 
significativamente a porção acometida(Tabela $n^{\circ} .49$ e 50). Ao final de dois anos $2.24 \%$ dos pacientes apresentaram-se com parestesia. Registrou-se presença de sintomatologia dolorosa em 1 paciente e esta se resolveu a partir do terceiro exame, sendo o implante considerado como sucesso devido a reversibilidade do quadro (Tabela $\mathrm{n}^{\circ} .47$ e 48).

As falhas podem se classificar em precoces e tardias, de acordo com BAUMGARTEN ${ }^{35}$, em 1995. As falhas foram precoces quando detectadas até a segunda cirurgia e tardias quando registradas depois da instalação da prótese. A etiologia da falha precoce foi relacionada com infecção pós-cirúrgica, carga prematura excessiva, fumo e trauma cirúrgico acentuado; quanto a falha tardia relacionou-se com problemas de incidência de cargas oclusais e infecciosas. De acordo com ROSENBERG; TOROSIAN; SLOTS ${ }^{175}$, subdividiu-se a etiologia das falhas dos implantes em traumática por incidência de forças excessivas e infecciosa. A sobrecarga oclusal pode ocasionar falha nos implantes mediante a associação de estresse excessivo transmitido ao osso com a ocorrência de microfraturas irreversíveis ${ }^{99,140}$. O tratamento deve se iniciar com a avaliação da adaptação, número, posição e contatos oclusais, e se necessário pode-se recorrer a terapia cirúrgica complementar com técnicas ressectivas ou regenerativas ${ }^{112}$. Além do fator oclusal ressalta-se a possibilidade da ocorrência de peri-implantite. Devido às similaridades clínicas, microbiológicas e histológicas com a doença periodontal denominou-se a destruição peri-implantar por acumulo de microorganismos como peri-implantite ${ }^{98,140}$. Contudo, existem divergências quanto a esta denominação, no ano de 1991, ZARB foi categórico no seguinte posicionamento: sem ligamento periodontal não existe doença periodontal. Não existe consenso quanto ao tratamento das peri-implantites sendo sugerido inicialmente o tratamento da superficie do implante por descontaminação com a eliminação das endotoxinas que aderem com alta afinidade $61,140,153$ e em seguida pode-se utilizar enxertos ósseos associados a membranas83,112,98,143. As falhas detectadas no terceiro e quarto exame não apresentaram quadro clínico passivel de dassificação precisa somente por sobrecarga oclusal ou peri-implantite. Em 
alguns casos pode ocorrer a superposição dos eventos, e advêm deste fato a dificuldade de discernimento clínico entre os dois tipos.

A partir dos dados expostos sobre os percentuais de sucesso relatados na literatura, em comparação com os registrados no NAPIO, observa-se similaridade entre estes. Os resultados com 2 anos obtidos com o sistema de implantes osseointegrados tratados com ataque ácido se apresentaram promissores. Contudo, necessita-se proceder o acompanhamento clínico e radiográfico destes continuamente depois da conexão da prótese, a fim de confirmar a existência a longo prazo da curva de estabilização das falhas dos implantes apresentada pelos outros sistemas. 

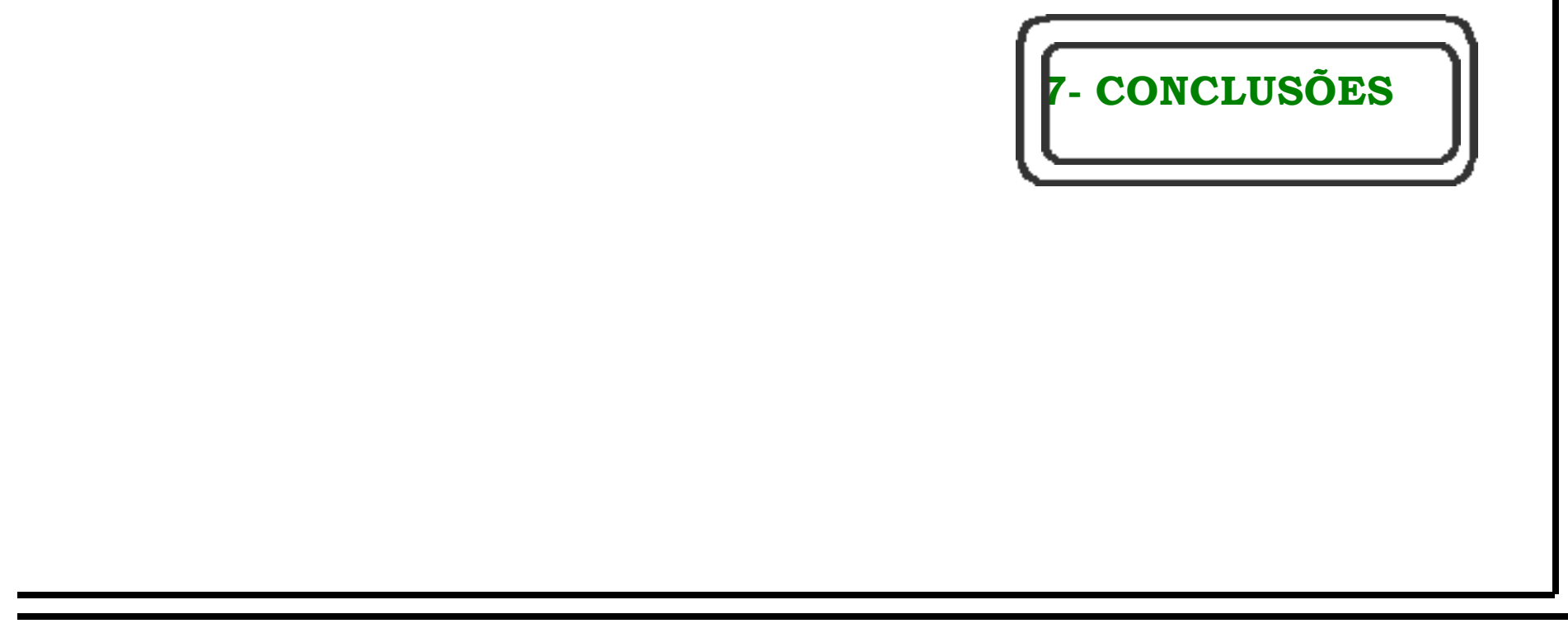


\section{7- CONCLUSÕES}

Considerando os resultados obtidos sobre o sucesso das próteses suportadas por implantes osseintegrados tratados com ataque ácido do sistema NAPIO, e levando-se em conta o contexto exposto e discutido, parecem lícitas as seguintes conclusões:

- Os implantes supriram os critérios de sucesso de SMITH; ZARB ${ }^{186}$ com índices de sucesso na maxila de $90.21 \%$ e mandíbula com 95.90\%. Estes resultados foram compativeis com os relatos da literatura, atestando a efetividade clínica nos dois primeiros anos da instalação da prótese;

- A partir da classificação dos implantes de acordo com a tabela de quatro campos de ALBREKTSSON; ZARB obteve-se percentual de sucesso decrescendo na maxila de $93.4 \%$ no primeiro exame para $78.24 \%$. Estes dados não refletiram o incremento das falhas, mas o aumento dos pacientes que não compareceram para manutenção denominados de não-computado.

- O percentual de sucesso das próteses foi de $99.25 \%$ na maxila e $100 \%$ na mandíbula, sendo similar aos resultados da literatura;

- A perda óssea média doi de $0.99 \mathrm{~mm}$, sendo na face mesial de $0.95 \mathrm{~mm}$ e na distal de $1.03 \mathrm{~mm}$, durante os dois anos, sendo este análogo ao encontrado nos estudos de acompanhamento longitudinal dos implantes;

- As falhas se concentraram até a segunda cirurgia e todas em implantes curtos;

- Não demonstrou-se correlação positiva entre pacientes fumantes e incremento do percentual de falhas; 
- A inflamação do tecido peri-implantar, presença de placa e sangramento a sondagem reduziram significativamente nos quatro exames. A medida de profundidade de sondagem e nível de inserção também diminuíram, porém de forma insignificantes;

- As principais complicações depois da instalação da prótese se relacionaram com reaperto e fratura do parafuso da prótese, sendo mais acentuada na mandibula do que na maxila;

- A sobre-dentaduras apresentam como principal complicação o reembasamento do clipe, seguido da fratura deste, e por fim o reembasamento da prótese;

- A mensuração subjetiva através de notas de 0 a 10 da satisfação do paciente em relação ao tratamento obteve média superior a nove para os aspectos relativos a função, estética e conforto. 


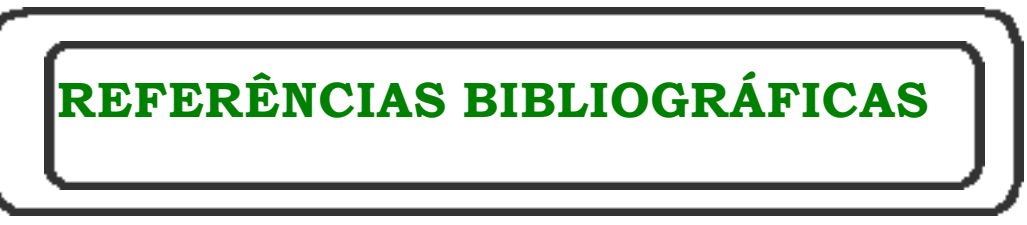




\section{REFERÊNCIAS BIBLIOGRÁFICAS*}

01-ADELL, R. Clinical results of osseointegrated implants supporting fixed prostheses in edentulous jaws. J. prosth. Dent., v.50, n.2, p.251-4, Aug. 1983.

02-ADELL, R. et al. A 15-year study of osseointegrated implants in the treatment of edentulous jaws. Int. J. oral Surg., v.10, n.6, p.387-416, June 1981.

03-ADELL, R. et al. Marginal tissue reactions at osseointegrated titanium fixtures. (I) A 3-year longitudinal prospective study. Int. J. oral Surg., v.15, n.1, p.39-52, Jan./Feb. 1986.

04-ADELL, R. et al. A long-term follow-up study of osseointegrated implants in the treatment of totally edentulous jaws. Int. J. oral Maxillofac. Implants, v.5, n.4, p.347-59, July/Aug. 1990.

05-AHLQVIST, J. et al. Osseointegrated implants in edentulous jaws: a 2-year longitudinal study. Int. J. oral Maxillofac. Implants, v.5, n.2, p. 155-63, Mar./Apr. 1990.

*Normas recomendadas para uso no âmbito da Universidade de São Paulo, com base no documento "Referências Bibliográficas: exemplos", emanado do Conselho Supervisor do Sistema Integrado de Bibliotecas da USP, em reunião de 20 de setembro de 1990. 
06-AKAGAWA, Y. et al. Clinical evaluation of the gingiva around single-cristal sapphire endosseous implant after experimental ligature-induced plaque accumulation in monkeys. J. prosth. Dent., v.68, n.1, p.111-5, July 1992.

07-ALBREKTSSON, T. A multicenter report on osseointegrated oral implants. J. prosth. Dent., v.60, n.1, p.75-84, July 1988.

08-ALBREKTSSON, T.; ISIDOR, F. Consensus report of Session IV. In: LANG, N.P.; KARRING, T. Proceedings of the 1st European workshop on Periodontology. Quintessence, Berlin, 1994. Cap. 4, p.365-73.

09-ALBREKTSSON, T.; LEKHOLM, U. Osseointegration: current state of the art. Dent. Clin. N. Amer., v.33, n.4, p.537-54, Oct. 1989.

10-ALBREKTSSON, T.; SENNERBY, L. Direct bone anchorage of oral implants: clinical and experimental considerations of the concept of osseointegration. Int. J. Prosthodont., v.3, n.1, p.30-41, Jan./Feb. 1990.

11-ALBREKTSSON, T.; SENNERBY, L State of the art in oral implants. J. clin. Periodont., v.18, n.6, p.474-81, July 1991.

12-ALBREKTSSON, T.; ZARB, G.A. Clinical results of a 24-team multicenter study of the Brånemark implant. In: __ The Bränemark osseointegrated implant. Quintessence, Berlin, 1989. Cap.15, p.229-32. 
13-ALBREKTSSON, T.; ZARB, G.A. Current interpretations of the osseointegration response: clinical significance. Int. J. Prosthodont., v.6 n.2 p.95-105, Mar./Apr. 1993.

14-ALBREKTSSON, T.; JANSSON, T.; LEKHOLM, U. Osseointegrated dental implants. Dent. Clin. N. Amer., v.30, n.1, p.151-74, Jan. 1986.

15-ALBREKTSSON, T. et al. The long-term efficacy of currently used dental implants: a review and proposed criteria of success. Int. J. oral Maxillofac. Implants, v.1, n.1, p.11-25, Jan./Feb. 1986.

16-ALBREKTSSON, T. et al. Osseointegrated oral implants: a swedish multicenter study of 8139 consecutively inserted Nobelpharma implants. J. Periodont., v.59, n.5, p.287-96, May 1988.

17-ANDERSSON, B. et al. Single-tooth restorations supported by osseointegrated implants: results and experiences from a prospective study after 2 to 3 years. Int. J. oral Maxillofac. Implants, v.10, n.6, p.702-11, Nov./Dec. 1995.

18-ANDERSON, B. et al. Cemented single crows on osseointegrated implants after 5 years: results from a prospective study on CeraOne. Int. J Prosthodont., v.11, n.3, p.212-8, May/June 1998.

19-ANDERSON, B. et al. Five-year prospective study of prosthodontic and surgical single-tooth implant treatment in general practices and at a specialist clinic. Int. J. Prosthodont., v.11, n.4, p.351-5, July/Aug. 1998. 
20-APSE, P. et al. The longitudinal effectiveness of osseointegrated dental implants. The Toronto study: peri-implant mucosal response. Int. J. Periodont. Restorat. Dent.,v.11, n.2, p.94-111, 1991.

21-ARAGONES, L. C. A. Análise comparativa do comportamento de implantes de Ti cp com diferentes tratamentos de superficie. Análises microscópica e de torque de remoção. Bauru, 1996.188 p. Tese (Doutorado) - Faculdade de Odontologia de Bauru, Universidade de São Paulo.

22-ARTZI, Z. et al. Mucosal consideration for osseointegrated J. prosth. Dent., v.70, n.5, p.427-32, Nov. 1993.

23-ARVIDSON, K. et al. A 3-year clinical study of Astra dental implants in the treatment of edentulous mandibles. Int. J. oral Maxillofac. Implants, v.7, n.3, p.321-9, May/June 1992.

24-ARVIDSON, K. et al. Five-year prospective follow-up report of the Astra Tech Dental Implant System in the treatment of edentulous mandibles. Clin. Oral Impl. Res., v.9, n.4, p. 225-34, Aug. 1998.

25-ÄSTRAND, P. et al. Combination of natural teeth and osseointegrated implants as prosthesis abutments: a 2-year longitudinal study. Int. J. oral Maxillofac. Implants, v.6, n.3, p.305-12, May/June 1991.

26-AVIVI-ARBER, L.; ZARB, G.A. Clinical effectiveness of implant-supported single-tooth replacement: the Toronto study. Int. J. oral Maxillofac. Implants, v.11, n.3, p.311-21, May/June 1996. 
27-BABBUSH, C.A. ITI Endosteal hollow cylinder implant systems. Dent. Clin. $\mathbf{N}$. Amer., v.30, n.1, p.133-49, Jan. 1986.

28-BABBUSH, C.A; SHIMURA, M. Five-year statistical and clinical observations with the IMZ two-stage osteointegrated implant system. Int. J. oral Maxillofac. Implants, v.8, n.3, p.245-53, May/June 1993.

29-BABBUSH, C.A. et al. Intramobile cylinder (IMZ) two-stage osteointegrated implant system with the Intramobile element (IME): part I- its rationale and procedures for use. Int. J. oral Maxillofac. Implants, v.2, n.4, p.203-16, July/Aug. 1987.

30-BAHAT, O. Treatment planning and placement of implants in the posterior maxillae: report of 732 consecutive Nobelpharma implants. Int. J. oral Maxillofac. Implants, v.8, n.2, p.151-61, Mar./Apr. 1993.

31-BAIN, C.A. Smoking and implant failure-benefits of a smoking cessation protocol. Int. J. oral Maxillofac. Implants, v.11, n.6, p.756-9, Nov./Dec. 1996.

32-BAIN, C.A.; MOY, P.K. Effects of smoking on failure rates of dental implants. Int. J. oral Maxillofac. Implants, v.7, n.1, p.123, Jan./Feb. 1992. /Abstract/.

33-BALSHI, T. J. An analysis and management of fractures implants: a clinical report. Int. J. oral Maxillofac. Implants, v.11, n.6, p.660-6, Nov./Dec. 1996. 
34-BAUMAN, G.R. et al. Clinical parameters of evaluation during implant maintenance. Int. J. oral Maxillofac. Implants, v.7, n.2, p.220-7, Mar/April 1992.

35-BAUMGARTEN, H.S. Ensuring success in Implant Prosthodontics. $5^{\text {th }}$ Annual Meeting of the dental implant clinical research group. Advances in dental implant reserch, clinical procedures and products. Impl. Dent., v.4, n.3, p.190-9, Fall 1995. /Abstract/

36-BAUMGARTEN, H.S.; CHICHE, G.J. Diagnosis and evaluation of complications and failures associated with osseointegrated implants. Compendium, v.16, n.8, p.814-16, Aug. 1995.

37-BECKER, W.; BECKER, B. Replacement of maxillary and mandibular molars with single endosseous implant restorations: a retrospective study. J. prosth. Dent., v.74, n.1, p.51-5, July 1995.

38-BECKER, W. et al. Clinical and microbiologic findings that may contribute to dental implant failure. Int. J. oral Maxillofac. Implants, v.9, n.6, p.31-8, Nov./Dec. 1990.

39-BELL, F.A. et al. Four-year experience with the placement, restoration and maintenance of dental implants by dental students. Int. J. oral Maxillofac. Implants, v.9, n.6, p.725-31, Nov./Dec. 1994.

40-BIANCU, S.; ERICSSON, I.; LINDHE, J. The periodontal ligament of teeth connected to osseointegrated implants. An experimental study in the beagle dog. J. clin. Periodont., v.22, n. 6, p.362-70, July 1995. 
41-BRÄGGER, U. Maintenance, monitoring, therapy of implant failures. In: LANG; N.P.; KARRING, T. Proceedings of the 1 st European Workshop on Periodontology. 1 a ed. London, Quintessence Publishig Co., 1994, Cap.IV, p.345-64.

42-BRÅNEMARK, P.I. Osseointegration and its experimental background. J. prosth. Dent., v.50, n.3, p.399-410, Sept. 1983.

43-BRÅNEMARK, P.I. et al. Intra-osseous anchorage of dental prostheses. Scand. J. plast. Reconstr. Surg., v.3, p.81-100, 1969.

44-BUSER, D.; WEBER, H.P.; BRÄGGER, U. The treatment of partially edentulous patients with ITI hollow-screw implant: presurgical evaluation and surgical procedures. Int. J. oral Maxillofac. Implants, v.5, n.2, p.165-74, Mar./Apr. 1990.

45-BUSER, D.; WEBER, H.P.; LANG, N.P. Tissue integration of non-submerged implants: 1-year results of a prospective study with 100 ITI hollow-cylinder and hollow-screw implants. Clin. Oral Impl. Res., v.1, n.1, p.33-40, Dec. 1990.

46-BUSER, D. et al. The new concept of ITI hollow-cylinder and hollow-screw implants: Part 2. Clinical aspects, indications, and early clinical results. Int. J.oral Maxillofac. Implants, v.3, n.2, p.173-81, Mar./Apr. 1988.

47-BUSER et al. Long-term evaluation of non-submerged ITI implants. Part 1: 8year life table analysis of a prospective multi-center study with 2359 implants. Clin. Oral Impl. Res., v.8, n.3, p.161-72, June 1997. 
48-CAMPOS JÚNIOR, A.; PASSANEZI, E. Por que a osseointegração revolucionou a Implantodontia? In: TODESCAN, F.F.; BOTINO, M.A.C. Atualização na clínica odontológica. A prática da clínica geral. Artes Médicas, São Paulo, 1996. Cap. 11, p.249-97.

49-CARLSON, B.; CARLSSON, G.E. Prosthodontic complications in osseointegrated dental implant treatment. Int. J. oral Maxillofac. Implants, v.9, n.1, p.90-4, Jan./Feb. 1994.

50-CARTER, G.M.; HUNTER, K. Six years experience with Brånemark osseointegrated implants. N. Z. dent. J., v.91, n.404, p.44-8, June 1995.

51-CHAYTOR, D.V. Clinical criteria for determining implant success: bone. Int. J. Prosthodont., v.6, n.2, p.145-52, Mar./Apr. 1993.

52-CHO, G.C.; CHEE, W.W.L. Apparent intrusion of natural teeth under an implant-supported prosthesis: a clinical report. J. prosth. Dent., v.68, n.1, p.3-5, July 1992.

53-CONSENSUS CONFERRENCE ON IMPLANTOLOGY, 1989, Mainz, West Germany: Proceedings. Int. J. oral Maxillofac. Implants, v.5, n.2, p.18271, Mar./Apr. 1990.

54-CORDIOLI, G.; CASTAGNA,S.; CONSOLATI, E. Single-tooth implant rehabilitation: a retrospective study of 67 implants. Int. J. Prosthodont., v.7, n.6, p.525-31, Nov./Dec. 1994. 
55-CORREIA, S.M.B. Sobrevivência a curto prazo de implantes osseointegrados tratados com ataque ácido do sistema Napio. Bauru, 1996. 197p. Dissertação (Mestrado) - Faculdade de Odontologia de Bauru, Universidade de São Paulo.

56-COX, J.F.; ZARB, G.A. The longitudinal clinical efficacy of ossseointegrated dental implants: a 3-year report. Int. J. oral Maxillofac. Implants, v.2, n.2, p.91-100, Mar./Apr. 1987.

57-CUNE, M.S.; PUTTER, C.; HOOGSTRATEN, J. Treatment outcome with implant-retained overdentures: Part I- clinical findings and predictability of clinical treatment outcome. J. prosth. Dent., v.72, n.2, p.144-58, Aug. 1994.

58-DAVIS, D.M.; ROGERS, J.O.; PACKER, M.E. The extent of maintenance required by implant-retained mandibular overdentures: a 3-year report. Int. J. oral Maxillofac. Implants, v.11, n.6, p.767-74, Nov./Dec. 1996.

59-DE BRUYN, H.; COLLAERT, B. The effect of smoking on early implant failure. Clin. Oral Impl. Res., v.5, n.4, p.260-4, Dec. 1994.

60-DE BRUYN, H. et al. Patient's opinion and treatment outcome of fixed rehabilitation on Brånemark implants. A 3-year follow-up study in private dental practices. Clin. Oral Impl. Res., v.8, n.4, p.265-71, Aug. 1997. 
61-DENNISON, D.K. et al. Contaminated implant surfaces: an in vitro comparison of implant surfece coating and treatment modalities for decontamination. J.Periodont., v. 65, n.10, p.942-8, Oct. 1994.

62-DEPORTER, D. A. et al. A histological assessment of the initial healing response adjacent to porous-surfaced, titanium alloy dental implants in dog. J. dent. Res. , v.65, n.8, p.1064-70, Aug. 1986.

63-DEPORTER, D. A. et al. Partially porous-coated dental implants - 2 year human clinical trial results. J. dent. Res., A.A.D.R. Abstr. \# 1201, v.71, p.256, 1992.

64-DEPORTER, D. A. et al. A prospective clinical study in humans of a partially porous-coated, endosseous dental implant: three to four year results. Int. J. oral Maxillofac. Implants, v.11, n1, p.87-95, Jan./Feb. 1996.

65-DEPORTER, D. A. et al. 6-7 years results of a prospective clinical trial using ENDOPORE implants to retain a mandibular overdentures. In: Annual Meeting of the Academy of Osseointegration. Atlanta, Mar. 1998. /Abstract/

66-DEPORTER, D. A. et al. Use of the Endopore dental implant to restore single teeth in the maxila: protocol and early results. Int. J. oral Maxillofac. Implants., v.13, n.2, p.263-72, Mar./Apr. 1998. 
67-DONATSKY, O. Osseointegrated dental implants with ball attachmentes supporting overdentures in patients with mandibular alveolar ridge atrophy. Int. J. oral Maxillofac. Implants, v.8, n.2, p.162-6, Mar./Apr. 1993.

68-DRAGO, C.J. Rates of osseointegration of dental implants with regard to anatomical location. Int. J. oral Maxillofac. Implants, v.7, n.1, p.125-6, Jan./Feb. 1992. /Abstract/.

69-EKFELDT, A.; CARLSSON, G.E.; BÖRJESSON, G. Clinical evaluation of single-tooth restoration supported by osseointegrated implants: a retrospective study. Int. J. oral Maxillofac. Implants, v.9, n.2, p.179-83, Mar./Apr. 1994.

70-ELLIES, L.G. Altered sensation following mandibular implant surgery: a retrospective study. J. prosth. Dent., v.68, n.4, p.664-71, Oct. 1992.

71-ENGQUIST, B. et al. A retrospective multicenter evaluation of osseointegrated implants supporting overdentures. Int. J. oral Maxillofac. Implants, v.3, n.2, p.129-34, Mar./Apr. 1988.

72-ERICSSON, I. et al. A clinical evaluation of fixed-bridge restorations supported by the combination of teeth and osseointegrated titanium implants. J. clin. Periodont., v.13, n.4, p.307-12, Apr. 1986.

73-ERICSSON, I. et al. Different types of inflammatory reactions in peri-implant soft tissues. J.clin. Periodont., v.22, n.3, p.307-12, Mar. 1995. 
74-FRIBERG, B.; GRÖNDAHL, K.; LEKHOLM, U. A new self-tapping Brånemark implant: clinical and radiographic evaluation. Int. J. oral Maxillofac. Implants, v.7, n.1, p.80-5, Jan./Feb. 1992.

75-FRIBERG, B.; JEMT, T.; LEKHOLM, U. Early failures in 4641 consecutively placed Brånemark dental implants: a study from stage 1 surgery to the connection of completed prostheses. Int. J. oral Maxillofac. Implants, v.6, n.2, p.142-6, Mar./Apr. 1991.

76-FRIBERG, B. et al. Mk II: the self-tapping Brånemark implant: 5-year result of a prospective 3-center study. Clin. Oral Impl. Res., v.8, n.4, p.279-85, Aug. 1997.

77-FUGAZZOTO, P.A.; WHEELER, S.L.; LINDSAY, J.A. Success and failures rates of cilynder implants in type IV bone. J. Periodont., v.64, n.11, p.1085-7, Nov. 1993.

78-FUGAZZOTO, P.A. et al. The use of IMZ osseointegrated implants in partially and completely edentulous patients: success and failures rates of 2023 implant cylinders up to $60+$ months in function. Int. J. oral Maxillofac. Implants, v.8, n.6, p.617-21, Nov./Dec. 1993.

79-GORMAN, L.M. et al. The effect of smoking on implant survival at secondstage surgery: DICRG interim report $\mathrm{n}^{\circ}$ 5. Impl. Dent., v.3, n.3, p.165-8, Fall 1994. 
80-GRANSTRÖM, G. et al. A detailed analysis of titanium implants lost in irradiated tissues. Int. J. oral Maxillofac. Implants, v.9, n.6, p.653-62, Nov./Dec. 1994.

81-GREGORY, M. A clinical study of the Brånemark dental implant system. Brit. dent. J., v.168, n.1, p.18-23, Jan. 1990.

82-GRÖNDAHL, K.; LEKHOLM, U. The predictive value of radiographic diagnosis of implant instability. Int. J. oral Maxillofac. Implants, v.12, n.1, p.5964, Jan./Feb. 1997.

83-GRUNDER, U. et al. Treatment of ligature-induced peri-implantitis using guided tissue regeneration: a clinical and histologic study in the beagle dog. Int. J. oral Maxillofac. Implants, v.8, n.3, p.282-93, May/June 1993.

84-GUNNE, J.; JEMT, T.; LINDÉN, B. Implant treatment in partially edentulous patients: a report on prostheses after 3 years. Int. J. Prosthodont., v.7, n.2, p.143-8, Mar./Apr. 1994.

85-HAAS, R. et al. Brånemark single tooth implants: a preliminary report of 76 implants. J. prosth. Dent., v.73, n.3, p.274-9, Mar. 1995.

86-HAAS, R. et al. Survival of $1.920 \mathrm{IMZ}$ implants followed for up to 100 months. Int. J. oral Maxillofac. Implants, v.11, n.5, p.581-8, Sept./Oct. 1996. 
87-HAAS, R. et al. The relationship of smoking on peri-implant tissues: a retrospective study. J. prosth. Dent., v.76, n.6, p.592-6, Dec. 1996.

88-HEMMINGS, SCHMITT, A.; ZARB, G.A. Complications and maintenance requirements for fixed prostheses and overdentures in the edentulous mandible: a 5-year report. Int. J. oral Maxillofac. Implants, v.9, n.2, p.191-6, Mar./Apr. 1994.

89-HENRY, P.J.; ADLER, E.A.; WALL, C.D. Osseointegrated dental implants: 2year follow-up replication study. Aust. dent. J., v.31, n.4, p.247-56, July/Aug. 1986.

90-HENRY, P.J.; BOWER, R.C.; WALL Reabilitation of the edentulous mandible with osseointegrated dental implants: a 10 year follow-up. Aust. dent. J., v.40, n.1, p.1-9, Jan./Feb. 1995.

91-HENRY, P.J.; TOLMAN, D.E.; BOLENDER, C. The applicability of osseointegrated implant in the treatment of partially edentulous: three-year results of a prospective multicenter study. Quintessence Int., v.24, n.2, p.123-30, Feb. 1993.

92-HENRY, P.J. et al. Osseointegrated implants for single tooth replacement in general practice: a 1-year report from a multicentre prospective study. Aus. dent. J., v.40, n.3, p.173-81, June 1995.

93-HENRY, P.J. et al. Osseointegrated implants for single-tooth replacement: a prospective 5-year multicenter study. Int. J. oral Maxillofac. Implants, v.11, n.4, p.450-5, July/Aug. 1996. 
94-HICKEY, J.S. et al. Microbiologic characterization of ligature-induced periimplantitis in the microswine model. J. Periodont., v.62, n.9, p.548-53, Sep. 1991.

95-HIGUCHI, K.W.; FOLMER, T.; KULTJE, C. Implant survival rates in partially edentulous patients: a 3-year prospective multicenter study. J. oral Maxillofac. Surg., v.53, n.3, p.264-8, Mar. 1995.

96-HOBO, S.; ICHIDA, E.; GARCIA, L.T. Osseointegration and occlusal rehabilitation. 2 ed., Quintessence, Tokyo, 1989.

97-HOSHAW, S. J.; BRUNSKI, J.B.; COCHRAN, G.V. B. Mechanical loading of Bränemark implants affects interfacial bone modeling and remodeling. Int. J. oral Maxillofac. Implants, v.9, n.3, p.345-60, May/June 1994.

98-HÜRZELER, M.B. et al. Treatment of peri-implantitis using guided bone regeneration and bone grafts, alone or in combination, in beagle dogs. Part 1: clinical findings and histologic observations. Int. J.oral Maxillofac. Implants, v.10, n.4, p.474-84, July/Aug. 1995.

99-ISIDOR, F. Histological evaluation of peri-implant bone at implants subjected to occlusal overload or plaque accumulation. Clin. Oral Impl. Res., v.8, n.1, p.1-9, Mar. 1994.

100-JAFFIN, R.A.; BERMAN, C.L. The excessive loss of Brånemark fixtures in type IV bone: a 5-year analysis. J. Periodont., v.62, n.1, p.2-4, Jan. 1991. 
101-JEMT, T. Failures and complications in 391 consecutively inserted fixed prostheses supported by Brånemark implants in edentulous jaws: a study of treatment from the time of prosthesis placement to the first annual checkup. Int. J. oral Maxillofac. Implants, v.6, n.3, p.270-6, May/June 1991.

102-JEMT, T.; LEKHOLM, U. Oral implant treatment in posterior partially edentulous jaws: a 5-year follow-up report. Int. J. oral Maxillofac. Implants, v.8, n.6, p.635-40, Nov./Dec. 1993.

103-JEMT, T.; LEKHOLM, U.; ADELL, R. Osseointegrated implants in the treatment of partially edentulous patients: a preliminary study on 876 consecutively placed fixtures. Int. J. oral Maxillofac. Implants, v.4, n.3, p.211-7, May/June 1989.

104-JEMT, T.; LEKHOLM, U.; GRÖNDAHL, K. A 3-year follow-up study of early single implant restorations ad modum Brånemark. Int. J. Periodont. Restorat. Dent., v.10, n. 5, p.341-9, 1990.

105-JEMT, T.; LINDÉN, B.; LEKHOLM, U. Failures and complications in 127 consecutively placed fixed partial prostheses supported by Brånemark implants: from prosthetic treatment to first annual checkup. Int. J. oral Maxillofac. Implants, v.7, n.1, p.40-4, Jan./Feb. 1992.

106-JEMT, T et al. Osseointegrated implants for single tooth replacement: a 1year report from a multicenter prospective study. Int. J. oral Maxillofac. Implants, v.6, n.3, p.29-36, May/June 1991. 
107-JEMT, T. et al. Failures and complications in 92 consecutively inserted overdentures supported by Brånemark implants in severely resorbed edentulous maxillae: a study from prosthetic treatment to first annual check-up. Int. J. oral Maxillofac. Implants, v.7, n.2, p.162-7, Mar./Apr. 1992.

108-JEMT, T. et al. A 5-year prospective multicenter follow-up report on overdentures supported by osseointegrated implants. Int. J. oral Maxillofac. Implants, v.11, n.3, p.291-8, May/June 1996.

109-JOHNS, R.B. A multicenter study of overdentures supported by Brånemark implants. Int. J. oral Maxillofac. Implants, v.7, n.4, p.513-22, July/Aug. 1992.

110-JOMI Current Issues Forum- To minimize complications, is it essential that implant abutments be surrounded by keratinized tissue? Int. J. oral Maxillofac. Implants, v.12, n.1, p.127-31, Jan./Feb. 1997.

111-JONES, J.K.; TRIPLETT, R.G. The relationship of cigarette smoking to impaires intraoral wound healing: a review of evidence and implications for patient care. J. oral Maxillofac. Surg., v.50, n. 3, p. 237-40, Mar. 1992.

112-JOVANOVIC, S.A. The management of peri-implant breakdown around functioning osseointegrated implants. J.Periodont.,v.64, n.11, p.117683, Nov. 1993. Supplement. 
113-KALLUS, T.; BESSING, C. Loose gold screws frequently occur in full-arch fixed prostheses supported by osseointegrated implants after 5 years. Int. J. oral Maxillofac. Implants, v.9, n.2, p.169-78, Mar./Apr. 1989.

114-KARLSSON, S.; JEMT, T. Adaptive changes of masticatory movement characteristics after rehabilitation with osseointegrated fixed prostheses in the edentulous jaw: a 10 year follow-up study. Int. J. oral Maxillofac. Implants, v.6, n.3, p.259-63, May/June 1991.

115-KARLSSON; GOTFREDSEN; OLSSON Single-tooth replacement by osseointegrated Astra Tech dental Implants: a 2-year report. Int. J. Prosthodont., v.10, n.4, July/Aug. 1997.

116-KARLSSON,U.; GOTFREDSEN,K.; OLSSON,C. A 2-year report on maxillary and mandibular fixed partial dentures supported by Astra Tech dental implants. A comparison of 2 implants with different surface textures. Clin. Oral Impl. Res., v.9, n.4, p.235-42, Aug. 1998.

117-KEAN, R.A.; BERRY, C.W.; CHILES, D.G. Antimicrobial activity of dental implant metal ions. J. dent. Res., v.67, p.142, 1988. Special issue. /Abstract n.239/

118-KIYAK, $\mathrm{H}$. et al. The phsycological impact of osseointegrated dental implants. Int. J. oral Maxillofac. Implants, v.5, n.1, p.61-9, Jan./Feb. 1992. 
119-KOHAVI, D. Complicatios in the tissue integrated prostheses components: clinical and mechanical evaluation. J. oral Rehab., v.20, n.4, p.413-22, July 1993.

120-KOMIYAMA, Y. Clinical and research experiences with osseointegrated implants in Japan. In: ALBREKTSSON, T.; ZARB, G.A. The Bränemark osseintegrated implant. Quintessence, Berlin, 1989. Cap.12, p.197-214.

121-KOUMJIAN, J.H.; KERNER, J.; SMITH, R.A. Hygiene maintenance of dental implants. J. Calif. dent. Ass., v.18, n.9, p.29-33, Sept. 1990.

122-KWAN, J.Y. Implant maintenance. J. Calif. dent. Ass.., v.19, n.12, p.45-9, Dec. 1991.

123-LANEY, W.R.; TOLMAN, D.E. The Mayo clinic experience with tissueintegrated prostheses. In: ALBREKTSSON, T.; ZARB, G.A. The Brånemark osseintegrated implant. Quintessence, Berlin, 1989. Cap.11, p.165-96.

124-LANEY, W.R. et al. Osseointegrated implants for single-tooth replacement: progress report from a multicenter prospective study after 3 years. Int. J. oral Maxillofac. Implants, v.9, n.1, p.49-54, Jan./Feb. 1994.

125-LANG, N.P. et al. Histologic probe penetration in healthy and inflamed periimplant tissues. Clin. Oral Impl. Res., v.5, n.4, p.191-201, Dec. 1994. 
126-LANGER, B.; SULLIVAN, D.Y. Osseointegration: its impact on the interrelationship of Periodontics and Restorative Dentistry: Part I. Int. J. Periodont. Restorat. Dent., v.9, n.2, p.85-105, 1989.

127-LEIMOLA-VIRTANEN, R. et al. ITI titanium plasma-sprayed screw implants in the treatment of edentulous mandibles: a follow-up study of 39 patients. Int. J. oral Maxillofac. Implants, v.10, n.3, p.373-8, May/June 1995.

128-LEKHOLM, U.; ZARB, G.A. Patient selection and preparation. In: BRÅNEMARK, P.I.; ZARB, G.A.; ALBREKTSSON, T. Tissue integrated Prosthesis: Osseointegration in clinical dentistry. Quintessence, Chicago, 1985. Cap. 5, p.199-209.

129-LEKHOLM, U. et al. Osseointegrated implants in the treatment of partially edentulous jaws: a prospective 5-year multicenter study. Int. J. oral Maxillofac. Implants, v.9, n.6, p.627-35, Nov./Dec. 1994.

130-LEMONS, J.; NATIELA, J. Biomaterials, biocompatibility and peri-implant considerations. Dent. clin. N. Amer., v.30, n.1, p.3-24, Jan. 1986.

131-LEVY, D. et al. A comparison of radiographic bone height and probing attachment level measurements adjacent to porous-coated dental implants in humans. Int. J. oral Maxillofac. Implants., v.12, n.4, p.541-6, July/Aug. 1997.

132-LINDQUIST, L.W.; CARLSSON, G.E.; GLANTZ, C.A. Rehabilitation of the edentulous mandible with tissue-integrated prosthesis: a six-year longitudinal study. Quintessence Int., v.18, n.2, p.89-96, 1987. 
133-LINDQUIST, L.W.; CARLSSON, G.E.; JEMT, T. Association between marginal bone loss around osseointegrated mandibular implants and smoking habits: a 10-year follow-up study. J. dent. Res., v.76, n.10, p.1667-74, Oct. 1997.

134-LINDQUIST, L.W.; CARLSSON, G.E.; ROCKLER, B. Bone resorption around fixtures in edentulous patients treated with mandibular fixed tissueintegrated prostheses. J. prosth. Dent., v.59, n.1, p.59-63, Jan. 1988.

135-LÖE, H.; SILNESS, J. Periodontal disease in pregnancy. II. Correlation between oral hygiene and periodontal conditions. Acta odont. scand., v.22, n.1, p.121-35, Feb. 1964.

136-MAGINI, R. S. Análise comparativa do comportamento de implantes de Ti cp com diferentes meios de armazenagem. Análises microscópica e torque de remoção. Bauru, 1997. 182p. Tese (Doutorado) - Faculdade de Odontologia de Bauru, Universidade de São Paulo.

137-MAKKONEN, T.A. et al. A 5-year prospective clinical study of Astra Tech dental implants supporting fixed bridges or overdentures in the edentulous mandible. Clin. Oral Impl. Res., v.8, n.6, p.469-75, Dec. 1997. 
138-McCOLLUM, J. et al. The effect of titanium implant abutment surface irregularities on plaque accumulation in vivo. J. Periodont., v.63, n.10, p. 802-5, Oct. 1992.

139-MEFfert, R.M. Treatment of the ailing failing implant. J. Calif. Dent. Assoc., v.20, n.6, p.42-5, June 1992.

140-MEFFERT, R.M. Periodontitis vs. peri-implantitis: the same disease? The same treatment? Crit. Rev. Oral Biol. Med., v.7, n.3, p. 278-91, 1996.

141-MEFFERT, R.M.; LANGER, B.; FRITZ, M.E. Dental implants: a review. J. Periodont., v.63, n.11, p.859-70, Nov. 1992.

142-MEIRA, K. B. Estudo comparativo de implantes de Ti cp com superfícies tratadas com ácido sulfúrico e óxido de titânio. Análise histológica e de torque de remoção. Bauru, 1995. 156p. Dissertação (Mestrado) Faculdade de Odontologia de Bauru, Universidade de São Paulo.

143-MELLONIG, J.T. et al. Treatment of the failing implant: case report. Int. J. Periodont. Restorat. Dent., v.15, n.4, p.384-95, Aug. 1995.

144-MERICSKE-STERN, R. et al. Peri-implant mucosal aspects of ITI implants supporting overdentures. A five-year longitudinal study. Clin. Oral Impl. Res., v.5, n.1, p.9-18, Mar. 1994.

145-MOBERG, L.-E. et al. Evaluation of single-tooth restorations on ITI dental implants. Clin. Oral Impl. Res., v.10, n.1, p.45-53, Feb. 1999. 
146-MOMBELli, A.W. Microbiology of dental implant. Advanc. dent. Res., v.7, n.2, p.202-6, Aug. 1993.

147-MOMBELLI, A.W. Criteria for success- monitoring. In: LANG, N.P.; KARRING, T. Proceedings of the 1st European workshop on Periodontology. Quintessence, Berlin, 1994. Cap. 4, p.297-316.

148-MOMBELLI, A.; LANG, N.P. Antimicrobial treatment of peri-implant infections. J. dent. Res., v.71, p.754, 1992. Special issue. /Abstract $1908 /$

149-MONCADA, A.C. Caracterização de superficies de titânio comercialmente puro grau I após diferentes tratamentos de superficie. Bauru, 1995. 234 p. Tese (Doutorado) - Faculdade de Odontologia de Bauru, Universidade de São Paulo.

150-MORGAN, M.J.; JAMES, D.F.; PILLIAR, R.M. Fractures of the fixtures component of an osseointegrated implant. Int. J. oral Maxillofac. Implants, v.8, n.4, p.409-14, July/Aug. 1989.

151-MÜHLEMAN, H.R.; SON, S. Gingival sulcus bleeding: a leading symptom in initial gingivitis. Helvetica Odontologica Acta, v.15, n.10, p.107-13, Oct. 1971.

152-NAERT, I. et al. A six-year prosthodontic study of 509 consecutively inserted implants for the treatment of partial edentulism. J. prosth. Dent., v.67, n.2, p.236-45, Feb. 1992. 
153-NELSON, S.K. et al. Lipopolysaccharide affinity for titanium implant biomaterials. J. prosth. Dent., v.77, n1, p.76-82, Jan. 1997.

154-NEVINS, M.; LANGER, B. The successful application of osseointegrated implants to the posterior jaw: a long-term retrospective study. Int. J. oral Maxillofac. Implants, v.8, n.4, p.428-32, July/Aug. 1994.

155-NEWMAN, M.; FLEMING, T. Periodontal considerations of implants and implants associated microbiota. J. dent Educ., v.52, n.12, p.737-44, Dec. 1988.

156-NIH Consensus conference statement: dental implants. Int. J. oral Maxillofac. Implants, v.3, n.4, p.290-3, July/Aug. 1988.

157-NIMI, A. et al. A japanese multicenter study of osseointegrated implants placed in irradiated tissues: a preliminary report. Int. $\mathbf{J}$ oral Maxillofac. Implants, v.12, n.2, p.259-64, Mar./Apr. 1997.

158-NISHIMURA, K. et al. Periodontal parameters of osseointegrated dental implants. A 4-year controlled follow-up study. Clin. Oral Impl. Res., v.8, n.4, p.272-8, Aug. 1997.

159-OLIVÉ, J.; APARICIO, C. The Periotest method as a measure of osseointegrated oral implant stability. Int. J. oral Maxillofac. Implants, v.5, n.4, p.390-400, July/Aug. 1990. 
160-OLSSON, M. et al. MK-II a modified self-tapping Brånemark implant: a 3year results of a controlled prospective pilot study. Int. J. oral Maxillofac. Implants, v.10, n.1, p.15-21, Jan./Feb. 1995.

161-PALMER, R.M. et al. A prospective study of Astra single tooth implants. Clin. Oral Impl. Res., v.8, n.3, p.173-9, June 1997.

162-PAREL, S.M.; TJELLSTRÖM, A. The United States and Swedish experience with osseointegration and facial prostheses. Int. J. oral Maxillofac. Implants, v.6, n.1, p.75-9, Jan./Feb. 1991.

163-PEREL, M.L. Parafunctional habits, nightguards, and root form implants. Impl. Dent., v.3, n.4, p. 261-3, Fall 1994.

164-PESUN, I.J. et al. Histological evaluation of abutment teeth in combination implant-tooth with fixed partial denture. J. dent. Res., v.77, p.171, 1998. Special issue A. / Abstract n. 528/

165-PILLIAR et al. Dental implant design - effect on bone remodeling. J. Biomed. Res., v.25, p.467-83, 1991.

166-PYLANT, T. et al. A retrospective evaluation of endosseous titanium implants in the partially edentulous patient. Int. J. oral Maxillofac. Implants, v.7, n.2, p.195-202, Mar./Apr. 1992.

167-QUIRYNEN, M. et al. Periodontal aspects of osseointegrated fixtures supporting an overdenture: a 4-year retrospective study. J. clin. Periodont., v.18, n.10, p.719-28, Nov. 1991. 
168-QUIRYNEN, M. et al. The reliability of pocket probing around screw-type implants. Clin. Oral Impl. Res., v.2, n.4, p.186-92, Oct./Dec. 1991.

169-QUIRYNEN, M. et al. Periodontal aspects of osseointegrated fixtures supporting a partial bridge: an up to 6-year retrospective study. J. clin. Periodont., v.19, n.2, p.118-26, Feb. 1992.

170-RAPLEY, J.W.; MILLS, M.P.; WYLAM, J. Soft tissue management during implant maintenance. Int. J. Periodont. Restorat. Dent., v.12, n.5, p.373-81, 1992.

171-RAZZOOG, M.E. Maintenance. In:WORTHINGTON, P.; LANG, B.R.; LaVELLE, W.E. Osseointegration in dentistry. An introduction. Illinois, Quintessence Publishing Co., 1994. Cap.11, p.125-34.

172-RIEDER, C.E.; PAREL, S.M. A survey of natural tooth abutment intrusion with implant-connected fixed partial dentures. Int.J. Periodont. Rest. Dent., v.13, n.4, p.334-47, Aug. 1993.

173-ROCHA, W. M. S. Análise da proliferação endosteal após a colocação de discos de Ti cp em coelhos, tratados por diferentes formas. 1996, 179p. Tese (Doutorado)- Faculdade de Odontologia de Bauru, Universidade de São Paulo.

174-ROSEN, H. Salvaging endosseous implants with fractured abutment screws. Impl. Dent., v.4, n.3, p.174-6, Fall 1995. 
175-ROSENBERG, E.S.; TOROSIAN, J.P.; SLOTS, J. Microbial differences in 2 clinically distinct types of failures of osseointegrated implants. Clin. Oral Impl. Res., v.2, n.3, p.135-44, July/Sept. 1991.

176-ROUMANAS, E. et al. Craniofacial defects and osseintegrated implants: sixyear follow-up report on the success rates of craniofacial implants at UCLA. Int. J. oral Maxillofac. Implants, v.9, n.5, p.579-85, Sept./Oct. 1994.

177-SALCETTI, J.M. et al. The clinical, microbial, and host response characteristics of the failing implants. Int. J. oral Maxillofac. Implants, v.12, n.1. p.32-42, Jan/ Feb. 1997.

178-SANT'ANA, E. Sobrevivência a curto prazo de implantes osseointegrados instalados em rebordos alveolares reconstruídos com enxerto ósseo autógeno. Bauru, 1997. 234p. Tese (Doutorado) - Faculdade de Odontologia de Bauru, Universidade de São Paulo.

179-SCHARF, D.R.; TARNOW, D.P. Success rates of ossseointegration for implants placed under sterile versus clean conditions. J. Periodont., v.64, n.10, p.954-6, Oct. 1993.

180-SCHMITT, A.; ZARB, G.A. The longitudinal clinical effectiveness of osseointegrated dental implants for single-tooth replacement. Int. J. Prosthodont., v.6, n.2, p.197-202, Mar./Apr. 1993.

181-SCHNITMAN, P.A.; SHULMAN, L.B. Recommendations of the consensus development conference on dental implants. J. Amer. dent. Ass., v.98, n.2, p.373-7, Mar. 1979. 
182-SCHELLER, H. et al. A 5-year multicenter study on implant-supported single crow restorations. Int. $\mathbf{J}$ oral Maxillofac. Implants, v.13, n.2, p.212-8, Mar./Apr. 1998.

183-SILNESS, J.; LÖE, H. Periodontal disease in pregnancy. I. Prevalence and severity. Acta odont. scand., v.21, n.6, p. 533-51, Nov./Dec. 1963.

184-SILVERSTEIN, P. Smoking and wound healing. Amer. J. Med., v.93, p.224, July 1992. Supplement A.

185-SMEDBERG, J.I. et al. A new design for a hybrid prosthesis supported by osseointegrated implants: Part 2- preliminary clinical aspects. Int. J. oral Maxillofac. Implants, v.6, n.2, p.154-9, Mar./Apr. 1991.

186-SMITH, D.E.; ZARB, G.A. Criteria for success of osseointegrated endosseous implants. J. prosth. Dent., v.62, n.5, p.567-72, Nov. 1989.

187-SONES, A.D. Complications with osseointegrated implants. J. prosth. Dent., v.62, n.5, p.581-5, Nov. 1989.

188-SPERANDIO, J. A. P. Análise comparativa com a reutilização de brocas para a implantação de parafusos de Ti cp. Análises microscópica e de torque de remoção na tíbia de coelhos. 1997, 188p. Tese (Doutorado)Faculdade de Odontologia de Bauru, Universidade de São Paulo.

189-STRUB, J.R.; GABERTHÜEL, T.W.; SCHÄRER, P. Role of attached gingiva for perimplant health in dogs. J. dent. Res., v.67, p.287, 1988. Special issue. /Abstract n.1396/ 
190-TOLMAN, D.E.; KELLER, E.E. Endosseous implant placement immediately following dental extraction and alveoloplasty: preliminary report with 6year follow-up. Int. J. oral Maxillofac. Implants, v.6, n.1, p.24-8, Jan./Feb. 1991.

191-TOLMAN, D.E.; LANEY, W.R. Tissue-integrated prosthesis complications. Int. J. oral Maxillofac. Implants, v.7, n.4, p.477-84, July/Aug. 1992.

192-TRIPLETT, R.G. et al. Endosseous cylinder implants in severely atrophic mandibles. Int. J. oral Maxillofac. Implants, v.6, n.3, p.264-9, May/June 1991.

193-VAN STEENBERGHE, D. A retrospective multicenter evaluation of the survival rate of osseointegrated fixtures supporting fixed partial prostheses in the treatment of partial edentulism. J. prosth. Dent., v.61, n.1, p.217-23, Feb. 1989.

194-VAN STEENBERGHE, D. et al. A prospective evaluation of the fate of 697 consecutive intra-oral fixtures modum Brånemark in the rehabilitation of edentulism. J. Neck \& Head Patho1., v.6, n.1, p.53-8, Jan./Feb. 1987.

195-VAN STEENBERGHE, D. et al. The applicability of osseointegrated oral implants in the rehabilitation of partial edentulism: a prospective multicenter study on 558 fixtures. Int. J. oral Maxillofac. Implants, v.5, n.3, p.272-81, May/June 1990.

196-VAN STEENBERGHE, D. et al. Periodontal indices around natural and titanium abutments: a longitudinal multicenter study. J. Periodont., v.64, n.6, p.538-41, June 1993. 
197-WALTON, J.N.; MAC ENTEE A prospective study on the maintenance of implant prostheses in private practice. Int. J. Prosthodont., v.10, n.5, p.453-8, Set./Oct. 1997.

198-WEISS, C.M. A comparative analysis of fibro-osteal and osteal integration and other variables that affect long term bone maintenance around dental implants. J. oral Implantol., v.13, n.3, p.467-87, May/June 1987.

199-WEYANT, R.J. Characteristics associated with the loss and peri-implant tissue health of endosseous dental implants. Int. J. oral Maxillofac. Implants, v.9, n.1, p.95-102, Jan./Feb. 1994.

200-WIJS, F.L.J.A.; CUNE, M.S.; PUTTER, C.D. Delayed implants in the anterior maxilla with the IMZ-implant system. J. oral Rehab., v.22, n.5, p.319-26, May 1995.

201-WILSON, T.G. et al. Maintenance problems and protocols. Int. J. oral Maxillofac. Implants, v.9, n.1, p.75-84, Jan./Feb. 1994. Supplement.

202-WISMEYER, D.; VAN WAAS, M.A.J.; VERMEEREN, J.I.J.F. Overdentures supported by ITI implants: a 6.5-year evaluation of patient satisfaction and prosthetic aftercare. Int. J. oral Maxillofac. Implants, v.10, n.6, p.744-9, Nov./Dec. 1995.

203-WOLINSKY, L.E.; CAMARGO,P.; SEGHI,R. In vitro adherence of Actinomyces viscosus and Streptococcus sanguis to titanium. J. dent. Res., v.67, p.287, 1988. Special issue. /Abstract n.1399/ 
204-WORTHINGTON, P. Complications and failures. In:WORTHINGTON, P.; LANG, B.R.; LaVELLE, W.E. Osseointegration in dentistry. An introduction. Illinois, Quintessence Publishing Co., 1994. Cap.11, p.125-34.

205-WORTHINGTON, P.; BOLENDER, C.L.; TAYLOR, T.D. The swedish system of osseointegrated implants: problems and complications encountered during a 4year trial period. Int. J. oral Maxillofac. Implants, v.2, n.2, p.77-84, Mar./Apr. 1987.

206-ZARB, G. Osseointegration: a requiem for the periodontal ligament? Int. J. Period. Restorat. Dent., v.11, n.2, p.88-91, 1991.

207-ZARB, G.A.; SCHMITT, A. The longitudinal clinical effectiveness of osseointegrated dental implants: the Toronto study. Part I: surgical results. J. prosth. Dent., v.63, n.4, p.451-7, Apr. 1990.

208-ZARB, G.A.; SCHMITT, A. The longitudinal clinical effectiveness of osseointegrated dental implants: the Toronto study. Part III: problems and complications encountered. J. prosth. Dent., v.64, n.2, p.185-94, Aug. 1990.

209-ZARB, G.A.; SCHMITT, A. The longitudinal clinical effectiveness of osseointegrated dental implants in anterior partially edentulous patients. Int. J. Prosthodont., v.6, n.2, p.180-8, Mar./Apr. 1993.

210-ZARB, G.A.; SCHMITT, A. The edentulous predicament II: The longitudinal effectiveness of implant-supported overdentures J. Amer. dent. Ass., v.127, p.66-72, 1996. 
211-ZARB, G.A.; SYMINGTON. J.M. Osseointegrated dental implants: preliminary report on a replication study. J. prosth. Dent., v.50, n.2, p.271-6, Aug. 1983.

212-ZARB, G.A.; SCHMITT, A.; BAKER, G. Tissue-integrated prostheses: osseointegration research in Toronto. Int. J. Periodont. Restorat. Dent., v.1, n.1, p.9-28, Jan./Feb. 1987. 


\section{ABSTRACT \\ LONGITUDINAL FOLLOW-UP OF NAPIO OSSEOINTEGRATED IMPLANTS}

IN FUNCTION FOR 2YEARS

Replace of missing teeth by osseointegrated implants has become an accepted treatment modality in clinical dentistry. The clinical efficacy of implant therapy has been demonstrated through a myriad of long-term studies following an established criteria for success and showing high survival rates. In those studies most of the failures were concentrated at the second stage surgery and in the first year following the insertion of the prostheses. In the present study, the success of 371 implants of the NAPIO (Center of Supporting Research in Dental Implants) implant system placed in function for 2 years were evaluated. These implants were used to support 135 single units and a variety of fixed and removable prothesis placed in 109 patients presenting partial and complete edentulism. The gender distribution encompassed $43 \%$ of males and $66 \%$ of females. The age range was between 17 and 82 years old. The implants were made of titanium grade I and acid etched. Clinical and radiografic evaluation were done every 6 months in the first year and then once a year for 2 years. The clinical evaluation was performed using several known periodontal parameters such as, probing depth, attachment level, presence of plaque, suppuration, edema and color alteration. For radiographic assessment, a standardized technique using an individually customized film holder with acrylic resin was used. The implants were evaluated using the success criteria described by SMITH; ZARB186. The success index for the mandible was $95.90 \%$ and for the maxilla $90.21 \%$ reflecting a clinical efficacy similar to others osseointegrated implant systems. Of the failing implants, $77 \%$ of those placed in the maxilla and $45.5 \%$ of the ones placed in the mandible 
were detected at second surgery, and were all of short length. The radiographs were digitized and measured using the software Sigma Scan Pro 4 (Jandel Scientifics) and the bone loss calculated for every time point. Results demonstrated an overall bone loss of $0.99 \mathrm{~mm}$ during 2 years. There were very little changes in probing depth and attachment level during the first 2 years and, almost no changes were found using parameters to access inflammation of the peri-implant tissue, presence of plaque, edema and bleeding on probing. The most frequent complication found in the prostheses assessment was loosening and fracturing of the retaining screw. The grades of confort, esthetics and function of the prostheses were assessed by the patients and the results were superior to 9.4 attesting the efficacy of the treatment from the patients point of view. It was concluded that the results found for clinical parameters, implants success, bone loss measured radiografically and complications found in the prosthesis during the first two years of follow-up were in agreement with results presented in the literature for other osseointegrated implant systems. 

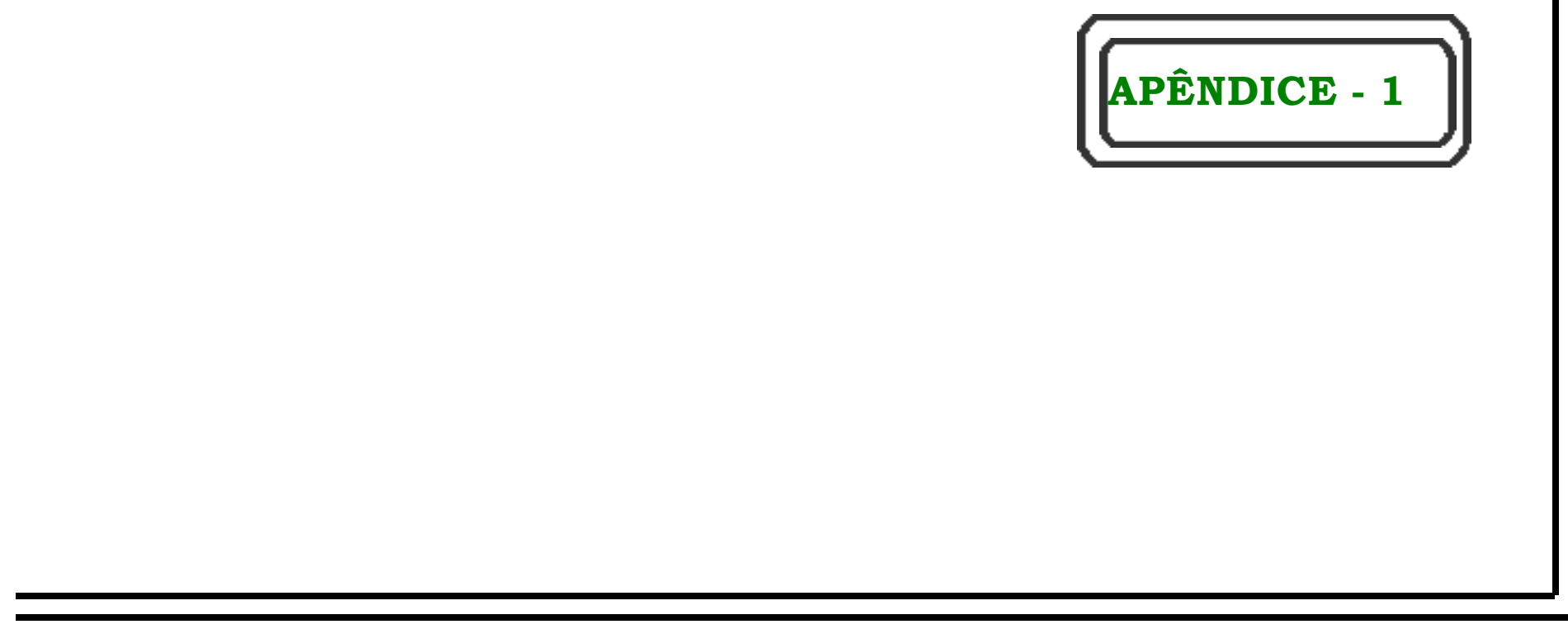


\section{FICHA DE MANUTENÇÃO}

\section{1-DADOS PESSOAIS:}

Nome:

Sexo:

Idade:

End.:

Telefone:

Data da instalação da prótese:

Arcada Superior / Inferior.

Data do atendimento:

\begin{tabular}{|c|c|}
\hline $\begin{aligned} \text { Fumante: } & \text { Sim } \\
& \text { Não }\end{aligned}$ & Quantos cigarros ao dia? \\
\hline $\begin{array}{r}\begin{array}{r}\text { Paciente foi submetido a: enxerto } \\
\text { radiação }\end{array} \\
\end{array}$ & $\begin{array}{ll}\text { Sim } & \text { Não } \\
\text { Sim } & \text { Não } \\
\end{array}$ \\
\hline
\end{tabular}

\begin{tabular}{|l|l|l|l|}
\hline Número de implantes: & & Inferior & \\
\hline Superior: & & Ss (Sucesso): & \\
\hline Ss (Sucesso): & & S1 (Sobrevivência): & \\
\hline S1 (Sobrevivência): & & U (Não computado): & \\
\hline U (Não computado): & & F (Falha): & \\
\hline F (Falha): & & Número total: & \\
\hline Número total: & & \\
\hline
\end{tabular}




\section{2-CARACTERÍSTICAS DA PRÓTESE:}

\section{Características da prótese:}

\begin{tabular}{l}
$\begin{array}{l}\text { Tipo de prótese: } \\
\text { Superior- } \\
\text { Inferior- }\end{array}$ \\
\hline
\end{tabular}


3-ÍNDICES CLÍNICOS:

Arcada Superior / Inferior:

\begin{tabular}{|c|c|c|c|c|c|c|c|c|c|c|c|c|c|c|c|c|c|c|}
\hline Implante & \multicolumn{3}{|c|}{$1(\mathrm{r})$} & \multicolumn{2}{|c|}{2(} & & \multicolumn{3}{|c|}{3(} & \multicolumn{2}{|c|}{4(} & & \multicolumn{3}{|c|}{5(} & \multicolumn{3}{|c|}{$6(\quad)$} \\
\hline $\begin{array}{l}\text { Profundidade de } \\
\text { sondagem }\end{array}$ & $\mathrm{M}$ & $\mathrm{V}$ & $\mathrm{D}$ & $\mathrm{M}$ & $\mathrm{V}$ & $\mathrm{D}$ & $\mathrm{M}$ & $\mathrm{V}$ & $\mathrm{D}$ & $\mathrm{M}$ & $\mathrm{V}$ & $\mathrm{D}$ & & $\mathrm{V}$ & $\mathrm{D}$ & $\mathbf{M}$ & $\mathrm{V}$ & $\mathrm{D}$ \\
\hline $\begin{array}{l}\text { Profundidade de } \\
\text { sondagem }\end{array}$ & $\mathrm{M}$ & $\mathrm{L}$ & $\mathrm{D}$ & $\mathrm{M}$ & $\mathrm{L}$ & $\mathrm{D}$ & $\mathrm{M}$ & $\mathrm{L}$ & $\mathrm{D}$ & $\mathrm{M}$ & $\mathrm{L}$ & $\mathrm{D}$ & $\mathrm{M}$ & $\mathrm{L}$ & $\mathrm{D}$ & $\mathrm{M}$ & $\mathrm{L}$ & $\bar{D}$ \\
\hline $\begin{array}{l}\text { Distância do topo } \\
\text { do intermediário à } \\
\text { margem gengival }\end{array}$ & $\mathrm{M}$ & $\mathrm{V}$ & $\mathrm{D}$ & $\mathrm{M}$ & V & $\mathrm{D}$ & M & V & $\mathrm{D}$ & $\mathrm{M}$ & V & $\mathrm{D}$ & $\mathrm{M}$ & $\mathrm{V}$ & $\mathrm{D}$ & $\mathrm{M}$ & $\mathrm{V}$ & $\mathrm{D}$ \\
\hline $\begin{array}{l}\text { Distância do topo } \\
\text { do intermediário à } \\
\text { margem gengival }\end{array}$ & $\mathrm{M}$ & $\mathrm{L}$ & $\mathrm{D}$ & $\mathrm{M}$ & $\mathrm{L}$ & $\mathrm{D}$ & $\mathrm{M}$ & $\mathrm{L}$ & $\mathrm{D}$ & $\mathrm{M}$ & $\mathrm{L}$ & $\mathrm{D}$ & $\mathrm{M}$ & $\mathrm{L}$ & $\mathrm{D}$ & $M$ & $\mathrm{~L}$ & $\mathrm{D}$ \\
\hline Nível de inserção & $\mathrm{M}$ & $\mathrm{V}$ & $\mathrm{D}$ & $\mathrm{M}$ & $\mathrm{V}$ & $\mathrm{D}$ & $\mathrm{M}$ & $\mathrm{V}$ & $\mathrm{D}$ & $\mathrm{M}$ & $\mathrm{V}$ & $\mathrm{D}$ & $\mathrm{M}$ & $\mathrm{V}$ & $\mathrm{D}$ & $\mathrm{M}$ & $\mathrm{V}$ & $\bar{D}$ \\
\hline Nível de inserção & $\mathrm{M}$ & $\mathrm{L}$ & $\mathrm{D}$ & $\mathrm{M}$ & $\mathrm{L}$ & $\mathrm{D}$ & $\mathrm{M}$ & $\mathrm{L}$ & $\mathrm{D}$ & $\mathrm{M}$ & $\mathrm{L}$ & $\mathrm{D}$ & $\mathrm{M}$ & $\mathrm{L}$ & $\mathrm{D}$ & $\mathrm{M}$ & $\mathrm{L}$ & $\mathrm{D}$ \\
\hline Presença de placa & M & V & D & M & V & $\mathrm{D}$ & M & V & D & M & V & D & $\mathrm{M}$ & V & $\mathrm{D}$ & $\mathrm{M}$ & $\mathrm{V}$ & $\mathrm{D}$ \\
\hline Presença de placa & $\mathrm{M}$ & $\mathrm{L}$ & $\mathrm{D}$ & $\mathrm{M}$ & $\mathrm{L}$ & $\mathrm{D}$ & $\mathrm{M}$ & $\mathrm{L}$ & D & $\mathrm{M}$ & $\mathrm{L}$ & $\mathrm{D}$ & $\mathrm{M}$ & $\mathrm{L}$ & $\mathrm{D}$ & $\mathrm{M}$ & $\mathrm{L}$ & $\mathrm{D}$ \\
\hline $\begin{array}{l}\text { Sangramento à } \\
\text { sondagem }\end{array}$ & & & & & & & & & & & & & & & & & & \\
\hline Edema & & & & & & & & & & & & & & & & & & \\
\hline Coloração & & & & & & & & & & & & & & & & & & \\
\hline Mobilidade & & & & & & & & & & & & & & & & & & \\
\hline Supuração & & & & & & & & & & & & & & & & & & \\
\hline
\end{tabular}




\section{4-CONTROLE RADIOGRÁFICO:}

Data:

Data:

Área:

Data: Área:

Data:

Data: Área:

Área:

Área:

5-CONTROLE MICROBIOLÓGICO:

Data: Área:

6-PROCEDIMENTOS CLÍNICOS REALIZADOS: 
APÊNDICE - 2

$\underline{\text { SIGLAS UTILIZADAS PARA DIGITAC̄ÃO DOS DADOS CLÍNICOS }}$ 


\begin{tabular}{|c|c|c|c|c|}
\hline \multirow[t]{2}{*}{ 1-SIGLAS UTILIZADAS PARA O NOME DO PACIENTE } & \multicolumn{4}{|c|}{$\begin{array}{c}\text { Presença aos } \\
\text { exames }\end{array}$} \\
\hline & $1 \mathrm{E}$ & $2 \mathrm{E}$ & $3 \mathbf{E}$ & $4 \mathrm{E}$ \\
\hline A1 ABIEL & $\mathbf{x}$ & $\mathbf{X}$ & $\mathbf{x}$ & $\mathbf{x}$ \\
\hline A2 ÁLVARO & $\mathbf{x}$ & $\mathbf{X}$ & $\mathbf{x}$ & $\mathbf{x}$ \\
\hline A3 AMYRES & $\mathbf{x}$ & $\mathbf{X}$ & $\mathbf{x}$ & $\mathbf{x}$ \\
\hline A4 ANA & $\mathbf{x}$ & $\mathbf{x}$ & $\mathbf{x}$ & $\mathbf{x}$ \\
\hline A5ANA & $\mathbf{x}$ & $\mathbf{x}$ & $\mathbf{x}$ & $\mathbf{X}$ \\
\hline A6ANGELO & $\mathbf{x}$ & $\mathbf{X}$ & $\mathbf{x}$ & $\mathbf{X}$ \\
\hline A7 ANTONIO & $\mathbf{x}$ & $\mathbf{x}$ & $\mathbf{x}$ & $\mathbf{x}$ \\
\hline A8 ANTONIO & $\mathbf{x}$ & $\mathbf{X}$ & $\mathbf{x}$ & $\mathbf{x}$ \\
\hline B1 ANTONIO & $\mathbf{x}$ & $\mathbf{x}$ & $\mathbf{x}$ & $\mathbf{x}$ \\
\hline B2 APARECIDA & $\mathbf{x}$ & $\mathbf{x}$ & $\mathbf{x}$ & \\
\hline B3 APARECIDA & $\mathbf{x}$ & $\mathbf{X}$ & $\mathbf{x}$ & \\
\hline B4 ARCHIMEDES & $\mathbf{x}$ & $\mathbf{x}$ & $\mathbf{x}$ & $\mathbf{x}$ \\
\hline B5 ARGEMIRO & $\mathbf{x}$ & $\mathbf{x}$ & $\mathbf{x}$ & $\mathbf{x}$ \\
\hline B6 ARMANDO & $\mathbf{x}$ & $\mathbf{x}$ & $\mathbf{x}$ & $\mathbf{x}$ \\
\hline B7 ARTEMIO & $\mathbf{x}$ & $\mathbf{x}$ & $\mathbf{x}$ & $\mathbf{X}$ \\
\hline B8 CADWALON & $\mathbf{x}$ & $\mathbf{x}$ & $\mathbf{x}$ & $\mathbf{X}$ \\
\hline C1 CARMELINDO & $\mathbf{x}$ & $\mathbf{x}$ & $\mathbf{x}$ & $\mathbf{x}$ \\
\hline C2 CASSIANO & $\mathbf{x}$ & $\mathbf{x}$ & $\mathbf{x}$ & $\mathbf{x}$ \\
\hline C3 CECILIA & $\mathbf{x}$ & - & - & - \\
\hline C4 CLARICE & $\mathbf{x}$ & $\mathbf{x}$ & $\mathbf{x}$ & $\mathbf{x}$ \\
\hline C5 CLAUDETE & $\mathbf{x}$ & $\mathbf{x}$ & $\mathbf{x}$ & $\mathbf{X}$ \\
\hline C6 CLAUDETE & $\mathbf{x}$ & - & - & \\
\hline C7 CLAÚDIO & $\mathbf{x}$ & $\mathbf{x}$ & $\mathbf{x}$ & $\mathbf{x}$ \\
\hline C8 DALVA & $\mathbf{x}$ & $\mathbf{x}$ & $\mathbf{x}$ & $\mathbf{x}$ \\
\hline D1 DENIZE & $\mathbf{x}$ & - & - & \\
\hline D2 DIRCE & $\mathbf{x}$ & $\mathbf{X}$ & $\mathbf{x}$ & $\mathbf{x}$ \\
\hline D3 DIRCE & $\mathbf{x}$ & $\mathbf{x}$ & $\mathbf{x}$ & $\mathbf{x}$ \\
\hline D4 DOÉLIO & $\mathbf{x}$ & $\mathbf{x}$ & $\mathbf{x}$ & $\mathbf{X}$ \\
\hline D5 DULCINÉIA & $\mathbf{x}$ & $\mathbf{X}$ & $\mathbf{x}$ & $\mathbf{X}$ \\
\hline D6 EDUARDO & $\mathbf{x}$ & $\mathbf{x}$ & $\mathbf{x}$ & $\mathbf{x}$ \\
\hline D7 EDNA & $\mathbf{x}$ & $\mathbf{X}$ & $\mathbf{x}$ & $\mathbf{X}$ \\
\hline D8 EDSON & $\mathbf{x}$ & $\mathbf{x}$ & $\mathbf{x}$ & $\mathbf{x}$ \\
\hline E1 ELI & $\mathbf{x}$ & $\mathbf{x}$ & $\mathbf{x}$ & $\mathbf{x}$ \\
\hline E2 ELIANA & $\mathbf{x}$ & $\mathbf{x}$ & $\mathbf{x}$ & $\mathbf{x}$ \\
\hline E3 ELISA & $\mathbf{x}$ & $\mathbf{x}$ & $\mathbf{x}$ & $\mathbf{x}$ \\
\hline E4 ELISABETH & $\mathbf{x}$ & $\mathbf{X}$ & $\mathbf{x}$ & $\mathbf{X}$ \\
\hline E5 ELZA & $\mathbf{x}$ & $\mathbf{x}$ & $\mathbf{x}$ & $\mathbf{x}$ \\
\hline E6 EMÍLIA & $\mathbf{x}$ & $\mathbf{x}$ & $\mathbf{x}$ & $\mathbf{x}$ \\
\hline E7 EURÍDES & $\mathbf{x}$ & $\mathbf{x}$ & $\mathbf{x}$ & $\mathbf{X}$ \\
\hline
\end{tabular}

OBS:Foram revelados somente os nomes incompletos dos pacientes, omitindo o sobrenome, a fim de preservar a privacidade destes. 


\begin{tabular}{|c|c|c|c|c|}
\hline SIGLAS UTILIZADAS PARA O NOME DO PACIENTE & $\overline{1 E}$ & $2 \mathbf{E}$ & $\overline{3 E}$ & 4E \\
\hline E8 FÁBIO & $\mathbf{X}$ & $\mathbf{X}$ & $\mathbf{x}$ & $\mathbf{X}$ \\
\hline F1 FERNANDO & $\mathbf{X}$ & $\mathbf{X}$ & $\mathbf{X}$ & $\mathbf{X}$ \\
\hline F2 FLÁVIO & $\mathbf{x}$ & $\mathbf{x}$ & $\mathbf{X}$ & $\mathbf{X}$ \\
\hline F3 GEISA & $\mathbf{X}$ & $\mathbf{x}$ & $\mathbf{X}$ & $\mathbf{X}$ \\
\hline F4 HAYDEE & $\mathbf{x}$ & - & - & - \\
\hline F5 HELENA & $\mathbf{x}$ & $\mathbf{X}$ & $\mathbf{X}$ & $\mathbf{X}$ \\
\hline F6 HÉLIO & $\mathbf{X}$ & $\mathbf{X}$ & $\mathbf{X}$ & $\mathbf{X}$ \\
\hline F7 HÉLIO & $\mathbf{x}$ & $\mathbf{X}$ & $\mathbf{X}$ & $\mathbf{X}$ \\
\hline F8 IZABEL & $\mathbf{X}$ & $\mathbf{X}$ & $\mathbf{X}$ & - \\
\hline G1 JANDIRA & $\mathbf{X}$ & $\mathbf{X}$ & $\mathbf{X}$ & - \\
\hline G2 JEANETE & $\mathbf{X}$ & $\mathbf{X}$ & $\mathbf{X}$ & $\mathbf{X}$ \\
\hline G3 JOÃO & $\mathbf{X}$ & $\mathbf{x}$ & $\mathbf{x}$ & $\mathbf{X}$ \\
\hline G4 JOÃO & $\mathbf{X}$ & $\mathbf{X}$ & - & - \\
\hline G5 JOSÉ & $\mathbf{X}$ & $\mathbf{X}$ & $\mathbf{X}$ & - \\
\hline G6 JOSÉ & $\mathbf{X}$ & $\mathbf{X}$ & $\mathbf{X}$ & $\mathbf{X}$ \\
\hline G7 JOSÉ & $\mathbf{X}$ & $\mathbf{X}$ & $\mathbf{X}$ & $\mathbf{x}$ \\
\hline G8 JOSÉ & $\mathbf{X}$ & $\mathbf{x}$ & $\mathbf{X}$ & $\mathbf{x}$ \\
\hline H1JOSÉ & $\mathbf{X}$ & $\mathbf{x}$ & $\mathbf{x}$ & $\mathbf{x}$ \\
\hline H2 JÚLIA & $\mathbf{X}$ & $\mathbf{x}$ & $\mathbf{X}$ & $\mathbf{x}$ \\
\hline H3 KAZUE & $\mathbf{X}$ & $\mathbf{x}$ & $\mathbf{x}$ & $\mathbf{x}$ \\
\hline H4 KEILA & $\mathbf{X}$ & $\mathbf{X}$ & - & - \\
\hline H5 LAURINDO & $\mathbf{X}$ & $\mathbf{X}$ & $\mathbf{X}$ & $\mathbf{X}$ \\
\hline H6 LEILA & $\mathbf{X}$ & $\mathbf{X}$ & $\mathbf{X}$ & $\mathbf{X}$ \\
\hline H7 LENA & $\mathbf{X}$ & $\mathbf{x}$ & $\mathbf{x}$ & $\mathbf{x}$ \\
\hline H8 LENIRA & $\mathbf{X}$ & $\mathbf{x}$ & $\mathbf{x}$ & $\mathbf{x}$ \\
\hline I1 LEONOR & $\mathbf{x}$ & $\mathbf{x}$ & $\mathbf{x}$ & $\mathbf{x}$ \\
\hline I2 LÍCIA & $\mathbf{X}$ & $\mathbf{X}$ & $\mathbf{X}$ & $\mathbf{x}$ \\
\hline I3 LICÍNIA & $\mathbf{X}$ & $\mathbf{X}$ & $\mathbf{X}$ & - \\
\hline I4 LOURIVAL & $\mathbf{X}$ & $\mathbf{X}$ & $\mathbf{x}$ & $\mathbf{X}$ \\
\hline I5 LUCILA & $\mathbf{X}$ & $\mathbf{x}$ & $\mathbf{X}$ & $\mathbf{x}$ \\
\hline I6 LÜCIO & $\mathbf{X}$ & $\mathbf{x}$ & $\mathbf{X}$ & $\mathbf{x}$ \\
\hline I7 LUIS & $\mathbf{X}$ & $\mathbf{x}$ & $\mathbf{X}$ & $\mathbf{x}$ \\
\hline I8 LUIS & $\mathbf{X}$ & $\mathbf{X}$ & $\mathbf{X}$ & $\mathbf{x}$ \\
\hline J1 LUIS & $\mathbf{X}$ & $\mathbf{X}$ & $\mathbf{X}$ & - \\
\hline J2 LUIZA & $\mathbf{X}$ & $\mathbf{X}$ & $\mathbf{X}$ & - \\
\hline J3 LUZIA & $\mathbf{X}$ & $\mathbf{X}$ & $\mathbf{X}$ & $\mathbf{X}$ \\
\hline J4 MAGALY & $\mathbf{X}$ & $\mathbf{X}$ & $\mathbf{X}$ & $\mathbf{X}$ \\
\hline J5 MAGNÓLIA & $\mathbf{X}$ & $\mathbf{X}$ & $\mathbf{x}$ & $\mathbf{x}$ \\
\hline J6 MAÍSA & $\mathbf{X}$ & $\mathbf{X}$ & $\mathbf{X}$ & $\mathbf{X}$ \\
\hline J7 MARCELO & $\mathbf{x}$ & $\mathbf{X}$ & $\mathbf{X}$ & $\mathbf{X}$ \\
\hline
\end{tabular}




\begin{tabular}{|l|c|c|c|c|}
\hline SIGLAS UTILIZADAS PARA O NOME DO PACIENTE & $\mathbf{1 E}$ & $\mathbf{2 E}$ & $\mathbf{3 E}$ & $\mathbf{4 E}$ \\
\hline J8 MARCIA & $\mathbf{X}$ & - & - & - \\
\hline K1 MARIA & $\mathbf{X}$ & $\mathbf{X}$ & - & - \\
\hline K2 MARIA & $\mathbf{X}$ & $\mathbf{X}$ & $\mathbf{X}$ & $\mathbf{X}$ \\
\hline K3 MARIA & $\mathbf{X}$ & - & - & - \\
\hline K4 MARIA & $\mathbf{X}$ & $\mathbf{X}$ & - & - \\
\hline K5 MARIA & $\mathbf{X}$ & $\mathbf{X}$ & $\mathbf{X}$ & $\mathbf{X}$ \\
\hline K6 MARIA & $\mathbf{X}$ & $\mathbf{X}$ & $\mathbf{X}$ & - \\
\hline K7 MARIA & $\mathbf{X}$ & $\mathbf{X}$ & $\mathbf{X}$ & $\mathbf{X}$ \\
\hline K8 MARÍLIA & $\mathbf{X}$ & $\mathbf{X}$ & $\mathbf{X}$ & $\mathbf{X}$ \\
\hline L1 MARÍLIA & $\mathbf{X}$ & $\mathbf{X}$ & $\mathbf{X}$ & $\mathbf{X}$ \\
\hline L2 MARLENE & $\mathbf{X}$ & $\mathbf{X}$ & $\mathbf{X}$ & $\mathbf{X}$ \\
\hline L3 MARILDA & $\mathbf{X}$ & $\mathbf{X}$ & $\mathbf{X}$ & $\mathbf{X}$ \\
\hline L4 MÁRIO & $\mathbf{X}$ & $\mathbf{X}$ & $\mathbf{X}$ & - \\
\hline L5 MARY & $\mathbf{X}$ & $\mathbf{X}$ & $\mathbf{X}$ & $\mathbf{X}$ \\
\hline L6 MILENA & $\mathbf{X}$ & $\mathbf{X}$ & $\mathbf{X}$ & - \\
\hline L7 NEIDE & $\mathbf{X}$ & $\mathbf{X}$ & $\mathbf{X}$ & $\mathbf{X}$ \\
\hline L8 NEYDE & $\mathbf{X}$ & $\mathbf{X}$ & $\mathbf{X}$ & $\mathbf{X}$ \\
\hline M1 OSNI & $\mathbf{X}$ & $\mathbf{X}$ & $\mathbf{X}$ & $\mathbf{X}$ \\
\hline M2 PEDRO & $\mathbf{X}$ & $\mathbf{X}$ & $\mathbf{X}$ & $\mathbf{X}$ \\
\hline M3 PEDRO & $\mathbf{X}$ & $\mathbf{X}$ & $\mathbf{X}$ & $\mathbf{X}$ \\
\hline M4 SALVADOR & $\mathbf{X}$ & $\mathbf{X}$ & $\mathbf{X}$ & $\mathbf{X}$ \\
\hline M5 SANTINA & $\mathbf{X}$ & $\mathbf{X}$ & $\mathbf{X}$ & $\mathbf{X}$ \\
\hline M6 SÍLVIA & $\mathbf{X}$ & $\mathbf{X}$ & $\mathbf{X}$ & $\mathbf{X}$ \\
\hline M7 STELA & $\mathbf{X}$ & $\mathbf{X}$ & $\mathbf{X}$ & $\mathbf{X}$ \\
\hline M8 TEREZA & $\mathbf{X}$ & $\mathbf{X}$ & $\mathbf{X}$ & $\mathbf{X}$ \\
\hline N1 TEREZINHA & $\mathbf{X}$ & $\mathbf{X}$ & $\mathbf{X}$ & $\mathbf{X}$ \\
\hline N2 VENÍCIO & $\mathbf{X}$ & $\mathbf{X}$ & $\mathbf{X}$ & $\mathbf{X}$ \\
\hline N3 VOLNEI & $\mathbf{X}$ & $\mathbf{X}$ & $\mathbf{X}$ & $\mathbf{X}$ \\
\hline N4 WALTER & $\mathbf{X}$ & $\mathbf{X}$ & $\mathbf{X}$ & $\mathbf{X}$ \\
\hline N5 WALTER & $\mathbf{X}$ & $\mathbf{X}$ & $\mathbf{X}$ & $\mathbf{X}$ \\
\hline N6 YVAN & $\mathbf{X}$ & $\mathbf{X}$ & $\mathbf{X}$ & $\mathbf{X}$ \\
\hline Número total & $\mathbf{1 0 9}$ & $\mathbf{1 0 3}$ & $\mathbf{9 9}$ & $\mathbf{8 9}$ \\
\hline & & & \\
\hline
\end{tabular}




\section{2-SEXO}

$\mathbf{F}=$ feminino

$\mathbf{M}=$ masculino

\section{3-IDADE}

Apresentada em números

\section{4-DATA DA INSTALAÇÃO DA PRÓTESE}

A data deveria ser obrigatoriamente digitada com todos os números, para não se omitir nenhum algarismo : 00/00/0000

\section{5-ARCADA RESTAURADS POR PRÓTESE SOBRE IMPLANTE}

$$
\begin{aligned}
& \mathbf{S}=\text { superior } \\
& \mathbf{I}=\text { inferior } \\
& \mathbf{S I}=\text { superior e inferior }
\end{aligned}
$$

\section{6-FUMANTE}

$\mathbf{S}=$ fumante

$\mathbf{N}=$ não fumante

\section{7-CIGARROS}

Número de cigarros ao dia

\section{8-SUBMETIDO A RADIAÇÃO}

$\mathbf{S}=\operatorname{sim}$

$\mathbf{N}=$ não

\section{9-ENXERTO}

$\mathbf{S}=\operatorname{sim}$

$\mathbf{N}=$ não 


\section{0-NÚMERO DE IM PLANTES}

Sup. $\mathbf{S}=$ superiores com sucesso

Sup. Sobe $=$ superiores com sobrevivência

Sup. $\mathbf{U}=$ superiores não computado

Sup.F = superiores falha

Sup. Total=superiores total

Inf. $\mathbf{S}=$ inferiores com sucesso

Inf. Sobe $=$ inferiores com sobrevivência

Inf. $\mathbf{U}=$ inferiores não computado

Inf.F $=$ inferiores falha

Inf. Total=inferiores total

\section{1-TIPO DE PRÓTESE SUPERIOR E INFERIOR}
A-Elemento unitário suportado por implantes
B-Sobre-dentadura suportada por implantes
C-Protocolo suportada por implantes
D-Prótese parcial com 2 elementos suportada por implantes
E-Prótese parcial com 3 elementos suportada por implantes
F-Prótese parcial com 4 elementos suportada por implantes
G-Dente natural
H-Prótese convencional
I-Prótese total
$\mathbf{J}$-Prótese suportada por implante em andamento
K-Prótese suportada por implante finalizada
L-Prótese removivel 


\section{2-COMPLICACÕES NA MAXILA}

S1-Inflamação do tecido gengival peri-implantar (0- ausente/ 1-leve/2-moderada/ 3-severa)

S2-Fratura da infra-estrutura da prótese (0- ausente/ 1- presente)

S3-Fratura do parafuso intermediário (0- ausente $/ \mathrm{n} .^{\circ}$ parafusos fraturados )

S4-Fratura do parafuso prótese $\left(\left(0-\right.\right.$ ausente $/ \mathrm{n} .^{\circ}$ de parafusos fraturados $)$

S5-Fratura do clipe (0- ausente/ 1- presente)

S6-Fratura da PT inferior X Sobre-dentadura superior (0- ausente/ 1-presente)

S7-Fratura da PT inferior X Protocolo superior (0- ausente/ 1- presente)

S8-Mobilidade da prótese (0- ausente/ 1- presente)

S9-Alteração na fonação (0- ausente/ 1- presente)

S10-Sintomatologia dolorosa (0-ausente/ 1- presente)

S11-Parestesia (0- ausente/ 1- presente)

S12-Parafusos soltos ou frouxos $\left(\left(0-\right.\right.$ ausente $/ \mathrm{n} .{ }^{\circ}$ de parafusos $)$

S13-Torque no intermediário ((0- ausente $/ \mathrm{n} .^{\circ}$ de intermediários)

S14-Desconforto muscular (0- ausente/ 1-presente)

S15-Desordens da ATM (0- ausente/ 1-presente)

S16-Necessidade de reembasamento (0-ausente/ 1 - presente)

S17-Troca de parafusos por desgaste no encaixe ou espanou(n. ${ }^{\circ}$ de parafusos)

S18-Desgaste da porcelana variando de 0 a 3 sendo: 0 desgaste não visível; 1desgaste único na faceta; 2-desgaste marcante na faceta; 3-desgaste extremo com destruição da morfologia oclusal.

S19-Reembasar ou trocar clipe (0-ausente/ 1-presente)

S20-Ajuste da oclusão (0- ausente/ 1- presente) 


\section{3-COMPLICAÇÕES NA MANDÍBULA}

I1 - Inflamação do tecido gengival peri-implantar (0-ausente/ 1-leve/2-moderada/ 3-severa)

I2-Fratura da infra-estrutura da prótese (0-ausente/ 1- presente)

I3-Fratura do parafuso do intermediário ( 0 - ausente $/ \mathrm{n} .^{\circ}$ de parafusos fraturados) I4-Fratura do parafuso da prótese (0- ausente/ n. ${ }^{\circ}$ de parafusos fraturados)

I5-Fratura do clipe (0-ausente/ 1 - presente)

I6-Fratura da PT superior. X Sobre-dentadura inferior (0-ausente/1-presente)

I7-Fratura da PT superior X Protocolo inferior (0-ausente/ 1- presente)

I8-Mobilidade da prótese (0-ausente / 1 - presente)

I9-Alteração na fonação (0- ausente/ 1- presente)

I10-Sintomatologia dolorosa (0- ausente/ 1 - presente)

I11-Parestesia (0-ausente/ 1-presente)

I12-Parafusos soltos ou frouxos (0- ausente/ $\mathrm{n} .^{\circ}$ de parafusos)

I13-Torque no intermediário (0- ausente/ $\mathrm{n}^{\circ}$ de intermediários)

I14-Desconforto muscular (0-ausente/ 1-presente)

I15-Desordens da ATM (0- ausente/ 1- presente)

I16-Necessidade de reembasamento ( 0 - ausente/ 1 - presente)

I17-Troca de parafusos por desgaste no encaixe ou espanou (0-ausente $/ \mathrm{n} .^{\circ} \mathrm{de}$ parafusos)

I18-Desgaste da porcelana variando de 0 a 3: 0 desgaste não visivel; 1-desgaste único na faceta; 2-desgaste marcante na faceta; 3-desgaste extremo com destruição da morfologia oclusal.

I19-Reembasar ou trocar clipe (0- ausente/ 1- presente)

I20-Ajuste da oclusão (0-ausente/ 1 - presente) 
14-PROFUNDIDADE DE SONDAGEM-Vestibular (V)

15-PROFUNDIDADE DE SONDAGEM- Lingual (L)

16-DISTÂNCIA TOPO DO INTERMEDIÁRIO A MARGEM GENGIVAL- (V)

17-DISTÂNCIA TOPO DO INTERMEDIÁRIO A MARGEM GENGIVAL- (L)

\section{8-NÍVEL DE INSERÇÃO- (V)}

19-NÍVEL DE INSERÇÃO- (L)

A profundidade de sondagem correspondia a medida de penetração da sonda no sulco ou bolsa peri-implantar. Com este instrumento mediu-se a distância do topo do intermediário até a margem gengival obtendo-se um ponto fixo. O nível de inserção foi a soma da medida de profundidade de sondagem com a distância do topo do intermediário. A primeira linha correspondia a face vestibular e a segunda para a lingual. Em cada um destes itens haviam 18 campos disponíveis, sendo que sempre deveria ser digitado o número "9" significando campo ausente para completar todos os espaços. Ou seja, se não houvessem 6 implantes correspondendo a 18 campos deveriam ser preenchidos os espaços vazios com o "9", por isto foram digitados 18 dígitos SEMPRE. Foi escolhido este número, pois não se encontrou este valor em nenhum dos casos. 
A primeira linha se referia a face vestibular e a segunda para a lingual, sendo que novamente os 18 campos deveriam ser totalmente preenchidos $\mathrm{e}$ as faces inexistentes completadas com o número "9".

$\mathbf{0}=$ ausente

$\mathbf{1}=$ presente

\section{2-SANGRAMENTO}

Presença ou ausência de alteração no sangramento a sondagem.

$\mathbf{0}=$ ausente

$\mathbf{1}=$ presente

\section{3-EDEMA}

Presença ou ausência de alteração no volume do tecido mole peri-implantar

$\mathbf{0}=$ ausente

$\mathbf{1}=$ presente

\section{4-COLORAÇÃO}

Presença ou ausência de alteração na cor do tecido mole peri-implantar

$\mathbf{0}=$ ausente

$\mathbf{1}=$ presente

\section{5-MOBILIDADE}

Presença ou ausência de alteração de mobilidade entre dois instrumentos

$\mathbf{0}=$ ausente

$\mathbf{1}=$ presente

\section{6-SUPURAC̄̃̃O}

Presença ou ausência de supuração

$\mathbf{0}=$ ausente

$\mathbf{1}=$ presente

27-APRESENTAC̣ÃO DAS NOTAS AFERIDAS PELOS PACIENTES (CRA)

Notas aferidas pelos pacientes em relação à função, estética e conforto:

CR1- função do superior (0 a 10)

CR2- estética do superior (0 a 10)

CR3- conforto do superior (0 a 10)

CR4- função do inferior (0 a 10)

CR5- estética do inferior (0 a 10)

CR6- conforto do inferior (0 a 10) 